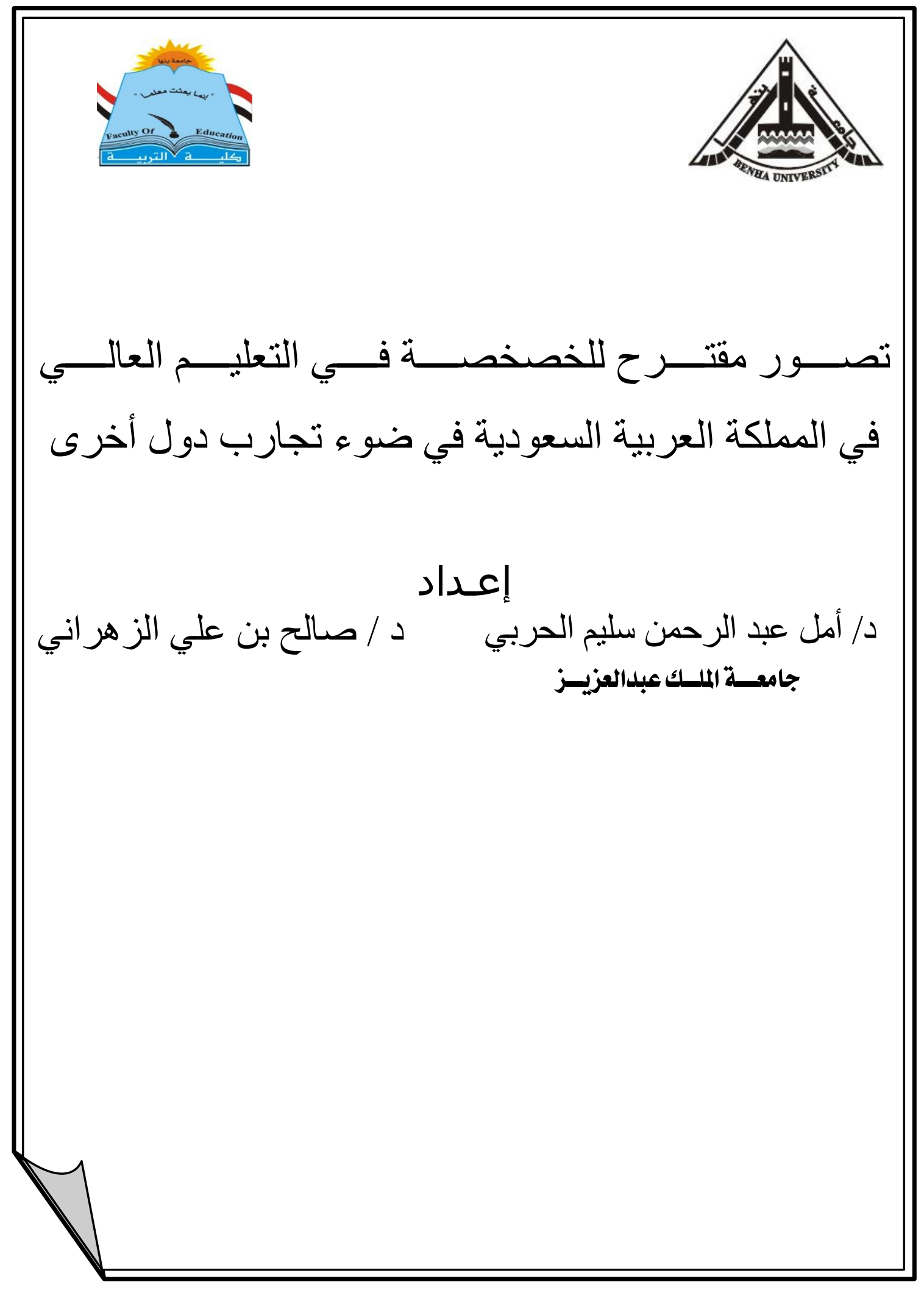




\section{مستخلــص الدراســــة}

هدف هذا البحث إلى رصد واقع الممارسات التطبيقية للخصخصة في مؤسسات التعليم

العالي في المملكة العربية السعودية، واستخدمت الباحثانة المنهج الوصفي المسحي والمقارن، وقامت ببناء استبانة مكونة من OV فقرة وزعت على ( . . (1) عضو من الأكاديميين في جامعة الملك عبد العزيز وكلية CBA بجدة. وتوصل البحث إلى النتائج التالية: جاءت درجة الموافقة حول واقع الممارسـات التطبيقيـة للخصخصـة "أوافق" لجميع أفراد العينـة، أمـا حول الإيجابيات التي تدعو للتوسع في الخصخصة جاءت بدرجة "أوافق" من وجهه نظر الأكاديميين في جامعة

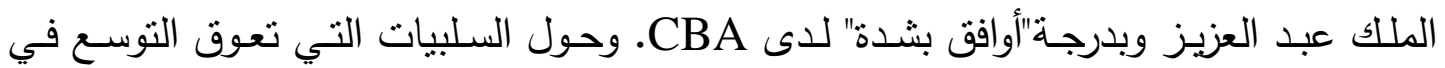

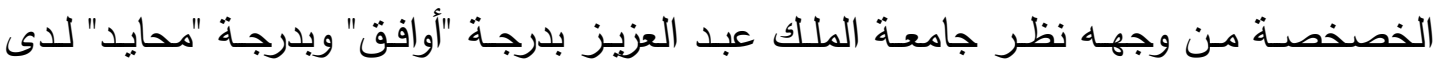
CBA. أما الإجراءات المقترح تطبيقها جاءت بدرجة "أوافق" لكلا" منهما .كما أظهرت النتائج وجود فرق ذا دلالة إحصائية بين متوسطات استجابات أفراد العينة حول الايجابيات تعزى "لنوع الجامعة" لصالحCBA ، وكذلك وجود فرق ذا دلالة إحصائية بين متوسطات استجابات أفراد العينة حول السلبيات تعزى"لنوع الجامعة" لصالح جامعة الملك عبد العزيز ، بينما لا يوجد فرق ذا دلالة إحصائية بين متوسطات استجابات أفراد العينة حول الواقع والإجراءات المقترح تطبيقها تعزى "لنوع الجامعة"، كما تم وضع تصور مقترح للخصخصة في مؤسسات التعليم العالي في المملكة.

وفي ضوء نتائج البحث توصي الباحثانة بالتوسع في مؤسسات التعليم العالي الخاصـة التي

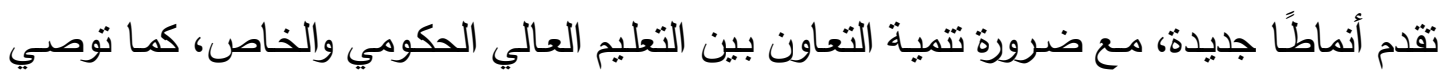
الباحثانة بتطبيق التصور المقترح على مؤسسات التعليم العالي الخاصة في المملكة. الكلمات المفتاحية: الخصخصة، تجارب عالمية، خصخصة التعليم العالي. 


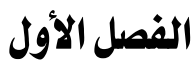

خطـــــــــة الدر اســــــــة

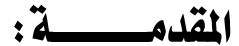

يواجه التعليم العالي في الوقت الحاضر ، تحديات تفرضها عليه مجموعة من التحولات

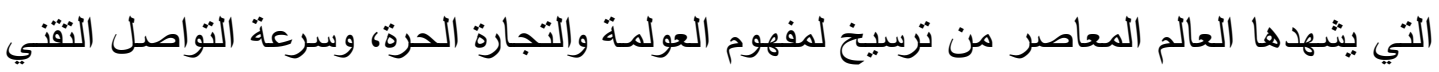

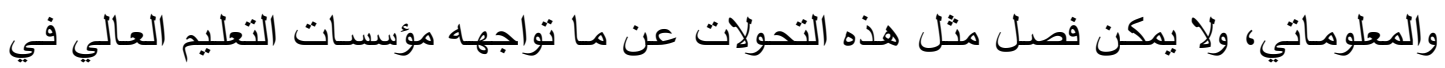
الوطن العربي من تحديات تتصل بالزيادات المخيفة في نسب بطالة الخريجين، والتوجه نحو الخصخصـة وانحسار دور القطاع الحكومي، وتدني مساهمة قطاع الإنتاج في شؤون التعليم

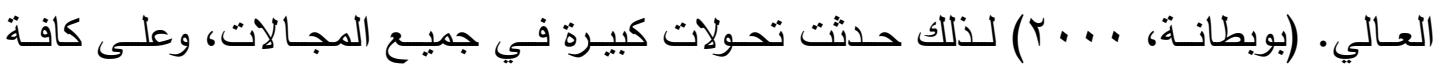

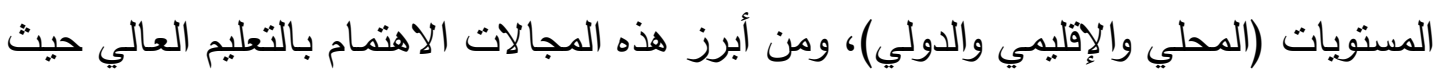

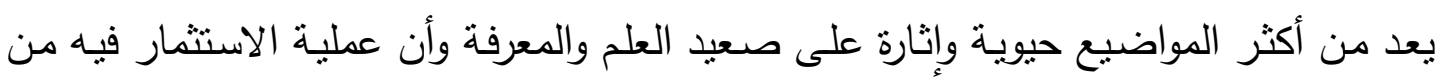
أبرز أنواع الاستثمار في رأس المال البشري.

فمؤسسات التعليم العالي تعد من المرتكزات التي تقوم عليها الدول التي تسعى لتحقيق التيق

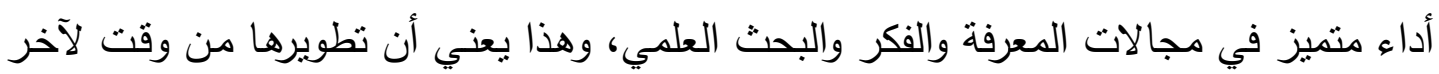
ضروري لحل مشكلات المجتمع والإسهام في تتميته وتطويره ومواكبة المتغيرات المعاصـرة.

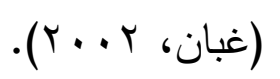

ومن المتفق عليه أن التعليم _ العالي تحديداً _ في معظم الدول العربية بات يعاني في

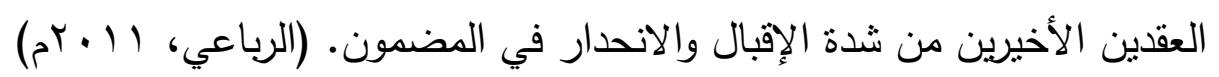

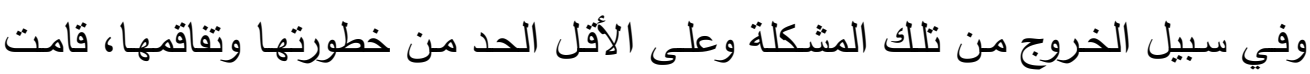

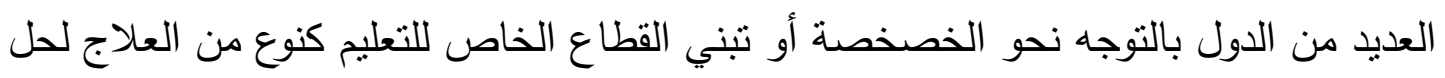

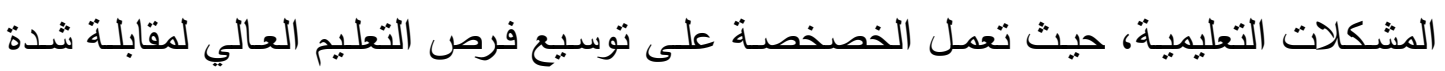

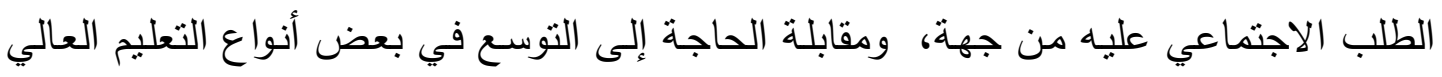

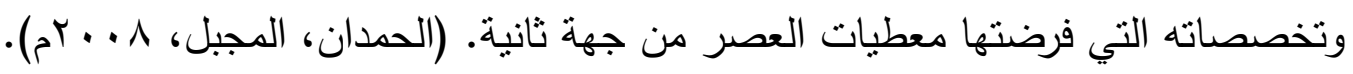

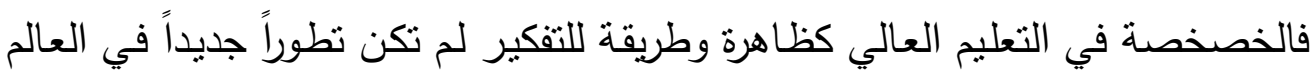

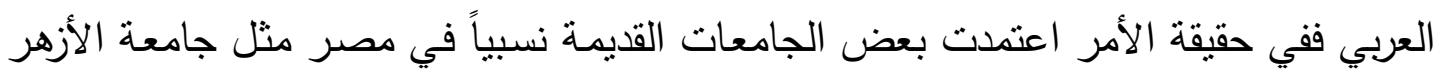

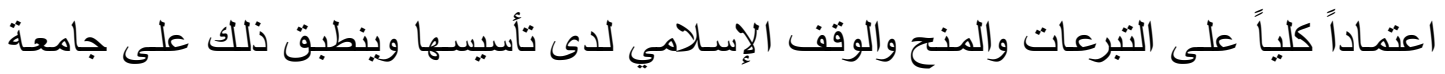




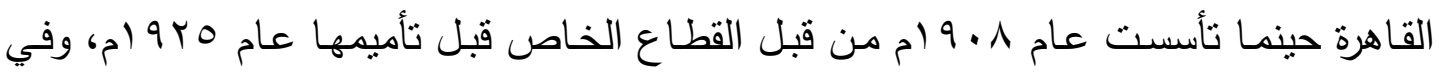

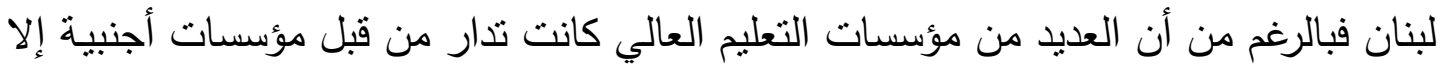

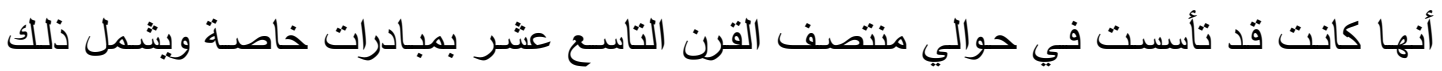

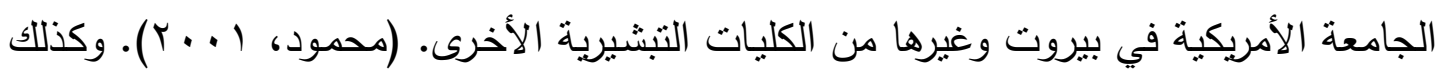

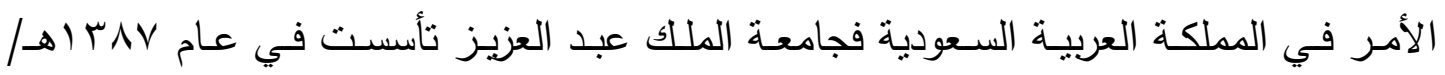
VT ام ام بصفتها جامعة أهلية، هدفها نشر التعليم العالي في المنطقة الغربية من المملكة العربية

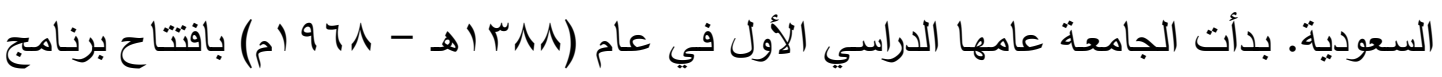

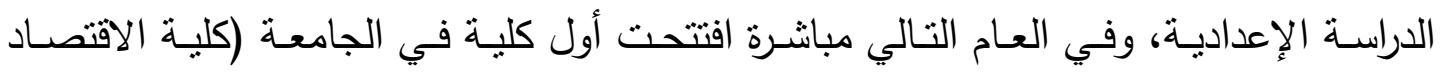

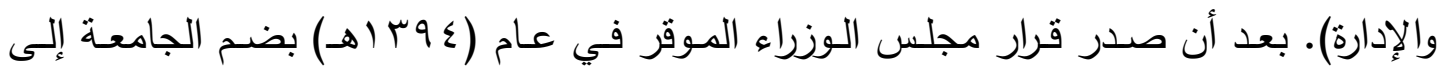

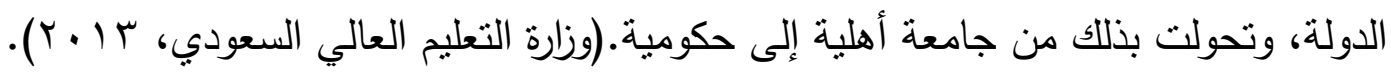

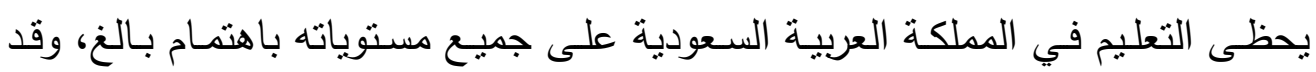
تضمنت الخطة التاسعة للتنمية ضمن أهدافها الاهتمام بتوسيع قاعدة التعليم العالي من خلال

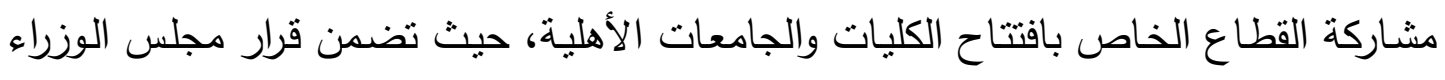

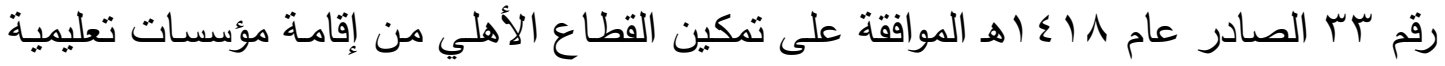

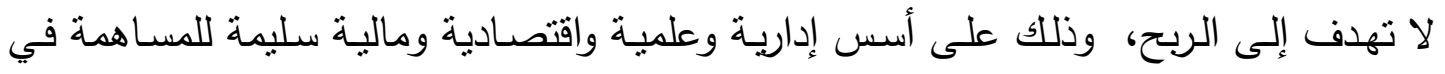
تلبيـة احتياجـات التتميـة مكملة بذللك الدور الذي تقوم بـه الجامعات الحكوميـة (خطـة التتميـة

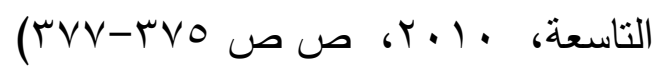
واتجهت المملكة العربيـة السعودية إلى الأخذ بخيار الخصخصـة بجانب دول عربيـة

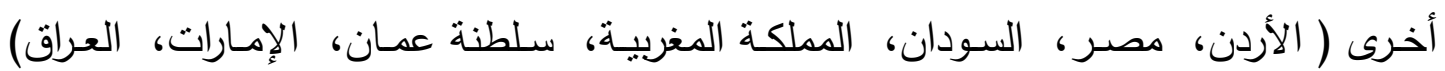

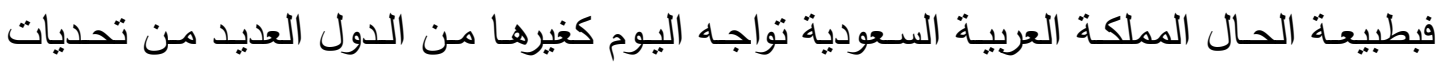
العصـر، لذللك زادت الحاجـة إلى الإصــلاح والتطوير التعليهـي لرفع كفـاءة العمليـة التعليميـة لمواجهة تحديات عصر العولمة والمعلوماتية، وسد الفجوة بين مخرجات التعليم واحتياجات سوق

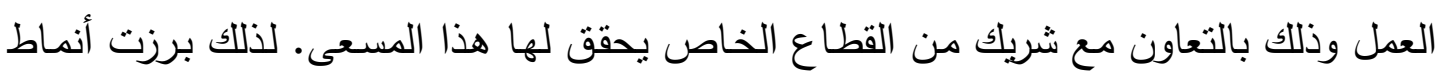

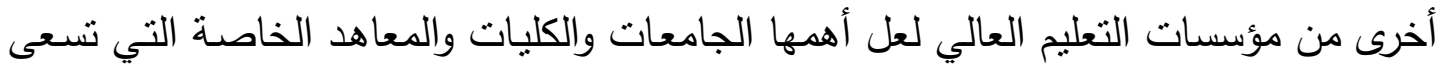

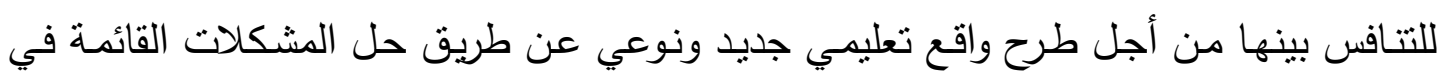

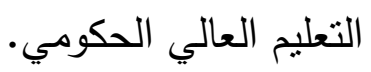


وقد أوصى مشروع آفاق الذي أطلقته وزارة التعليم العالي السعودي على ضوء تعاليم

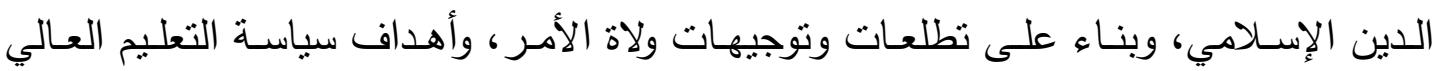
بالمملكة كخطة مستقبلية إستراتيجية بعيدة المدى ـ لفترة خمس وعشرين سنة ـللتعليم الجامعي بالمملكة العربية السعودية بضرورة تعزيز ودعم التعليم العالي الأهلي والاستفادة من الممارسات

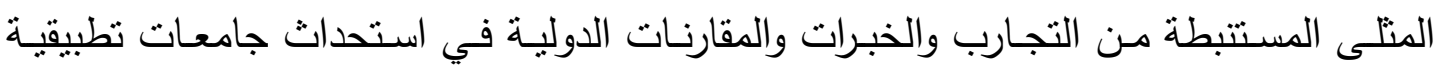
وبحثيـة متخصصـة في عدد مـن المنـاطق حيث براعي فيهـا التوازن بين المفـاهيم النظريـة والتطبيقية، من أجل الارتقاء بالتعليم العالي بالمملكة إلى آفاق جديدة وجعله قادرا على المنافسة

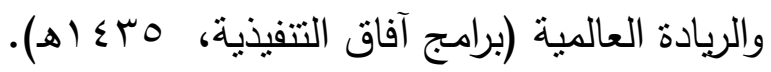
وكذلك أوصت الكثثر من الدراسات والبحوث بالاستفادة من التجارب العالمية وضرورة

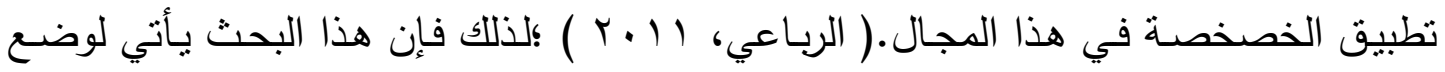

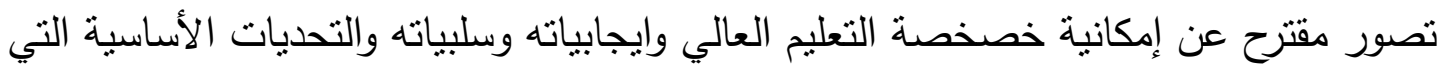
تواجه خصخصة هذا النوع من التعليم.

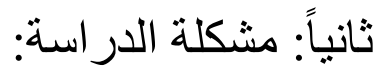
بناء على ما سبق ذكره من امتداد نيار الخصخصة في نظام التعليم العالي وماله من

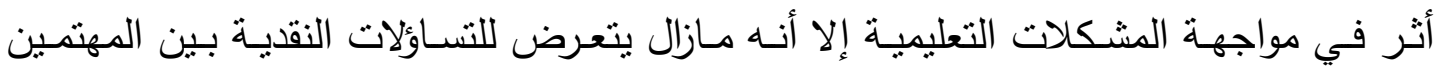
بالثُؤون التعليمية، وفي ضوء توجها وزارة التعليم العالي السعودي لتنفيذ مشروع (آفاق) الذي الذي أطلقته الوزارة كخطة مستقبلية للتعليم الجامعي في المملكة العربية السعودية فقد كان تعزيز دور

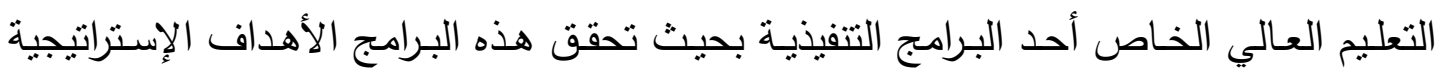

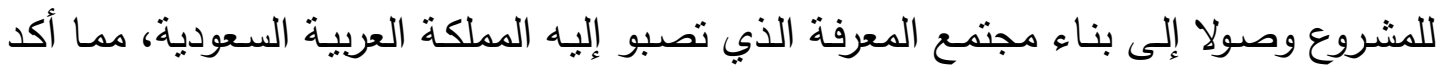

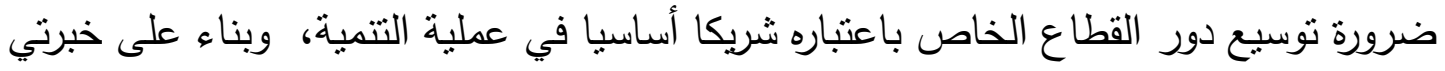
في الميدان التربوي لاحظت وجود أزمة في التعليم متجسدة في ظهور المشكيكاتلات الأكاديمية التي تحتاج لاعم فكرة الخصخصة كمدخل للإصلاح.

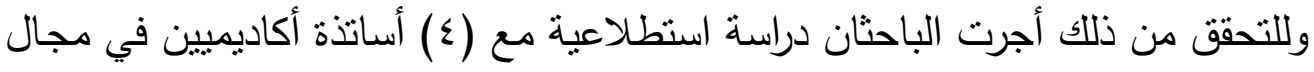

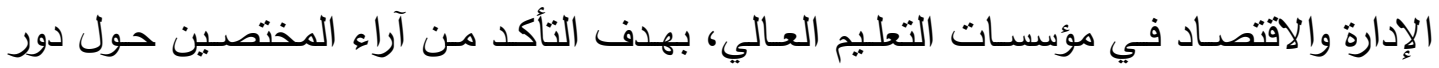

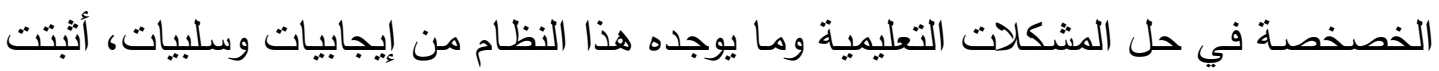

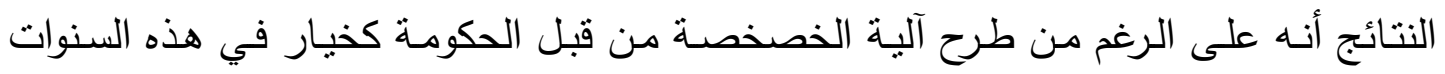

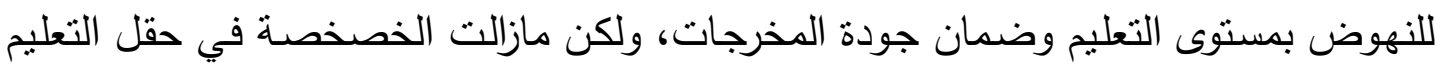

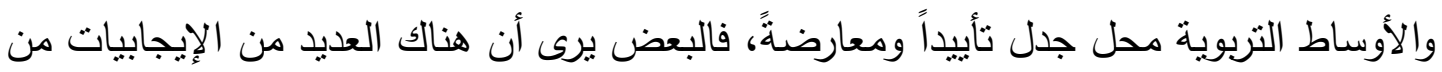




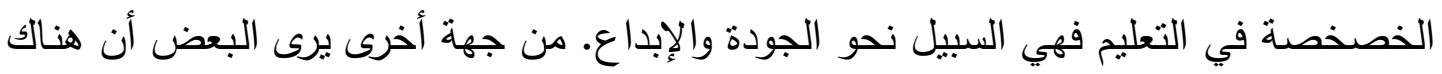

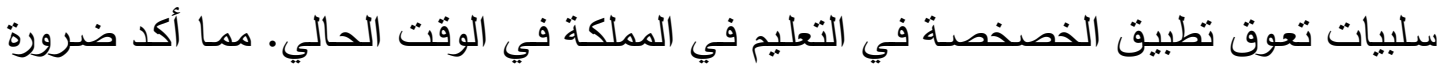

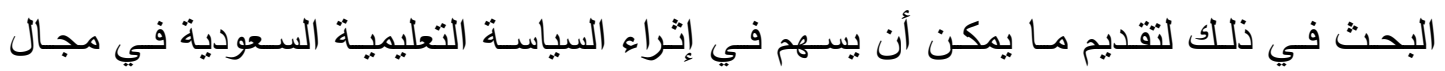
الخصخصة في مؤسسات التعليم العالي بما يضمن تحقيق وضع مستقبلي يتوافر فيه الجودة، والتمايز ، والمنافسة على الريادة العالمية له. له. ومن هنا تبلورت مشكلة البحث في السؤال الرئيس التالي:

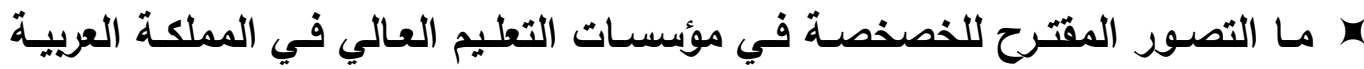

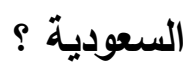
ثالثاً: أسئلــــة الدر اســـة: سعت الاراسة الحالية للإجابة عن الأسئلة التالية: 1- ما واقع الممارسات التطبيقية للخصخصة في مؤسسات التعليم العالي في المملكة العربية

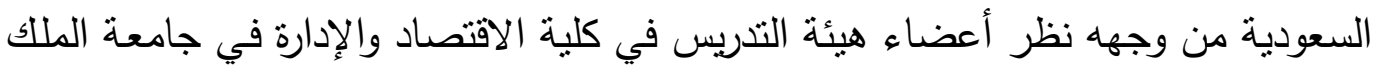

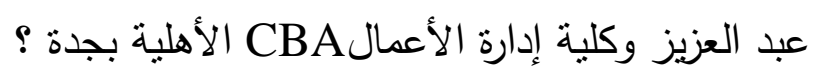

r- ما الايجابيات التي تدعو للتوسع في الخصخصة في مؤسسات التعليم العالي في المملكة

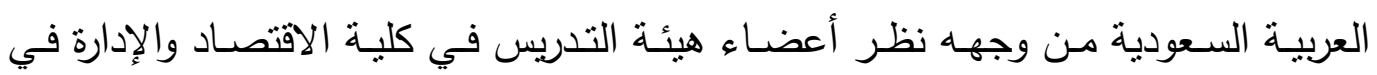
جامعة الملك عبد العزيز وكلية إدارة الأعمال CBA الأهلية بجدة ؟ r- مـا السلبيات التي تعوق التوسع في الخصخصة في مؤسسات التعليم العالي في المملكة

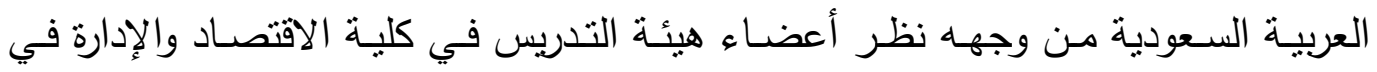
جامعة الملك عبد العزيز وكلية إدارة الأعمال CBA الأهلية بجدة ؟

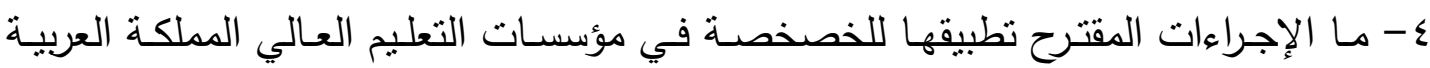

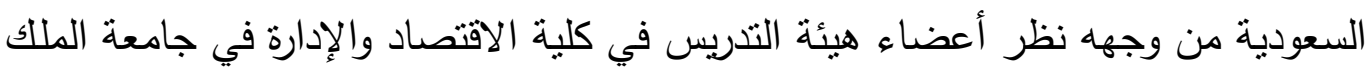

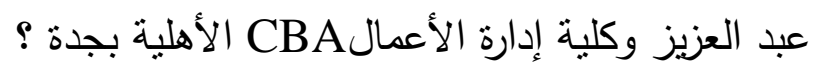

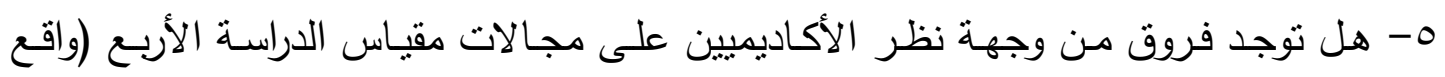

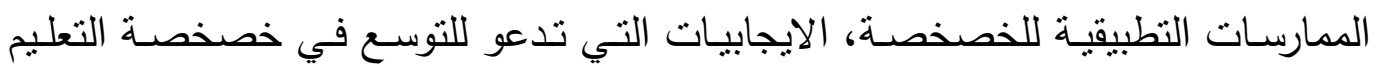

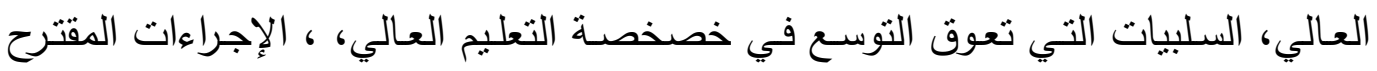
تطبيقها للخصخصة في مؤسسات التعليم العالي ) تعزى لنوع الجامعة ؟ 
سعت هذه الاراسة إلى تحقيق الأهداف التالية:

$$
\text { رابعاً: أهـــداف الدر اســـة: }
$$

يهرف البحث إلى:

1. رصد واقع الممارسات التطبيقية للخصخصة في مؤسسات التعليم العالي في المملكة العربية

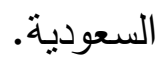

r. الوقوف على الايجاييات الداعيـة للخصخصـة في مؤسسـات التعليم العـالي في المملكـة

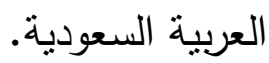

r. التعرف على السلبيات التي تواجها الخصخصـة في مؤسسـات التعليم العالي في المملكة

$$
\text { العربية السعودية. }
$$

ع. تحديد الإجراءات المقترح تطبيقها للخصخصـة في مؤسسـات التعليم العـالي في المملكة

$$
\text { العربية السعودية. }
$$

ه. التعـرف على الفـروق مـن وجهـة نظـر الأكـاديميين حـول واقـع الممارســات التطبيقيـة

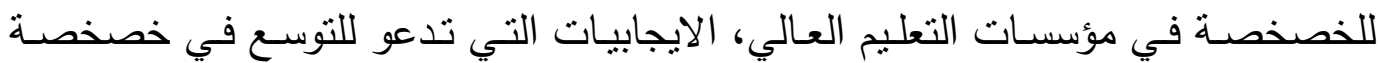

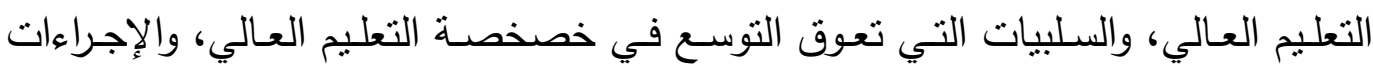
المقترح تطبيقها للخصخصة في مؤسسات التعليم العالي تعزى لنوع الجامعة.

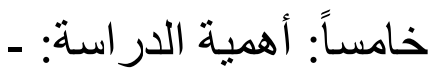
من المؤمل أن تفيا نتائج هذا البحث الفئات التالية: I. المسؤولين في وزارة التعليم العالي بتوضيح الايجابيات من الخصخصة في التعليم العالي، والسلبيات التي قد تتتج بسبب تطبيقها مما يساعد على تلافيها.

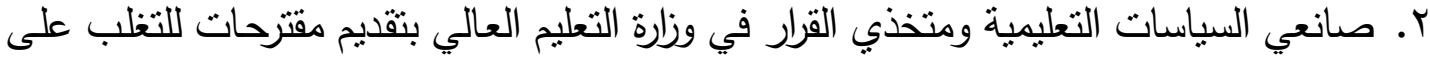
المعوقـات والصـعوبات التي تحسول دون تطييق الخصخصـة في مؤسســات التعليم العـالي ولتطبيقها بشكل علمي بناء على خبرات دول أخرى لها السبق في هذا المجال.

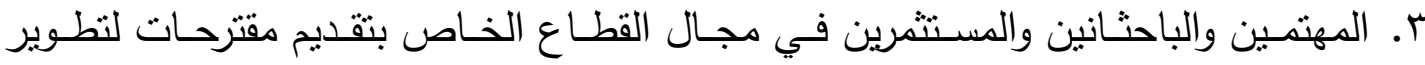
الخصخصة في مؤسسات التعليم العالي الخاصة. ع. القيادات التربوية العليا في وزارة التعليم العالي بإمدادهم ببدائل لدصادر تمويل التعليم العالي وفقا للنوجهات العالمية المصحوبة بالتطور العلمي.

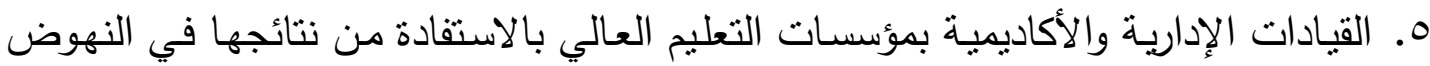

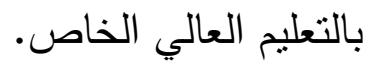


ا من خلال ما نم عرضه في الإطار النظري نم اتخاذ التعريف الإجرائي التالي:

\section{خصخصة التعليم العالي (إجرائياً) :}

يقصد بمصطلح خصخصـة التعليم العالي قيام القطاع الخاص بتمويل وإدارة وامتلالك

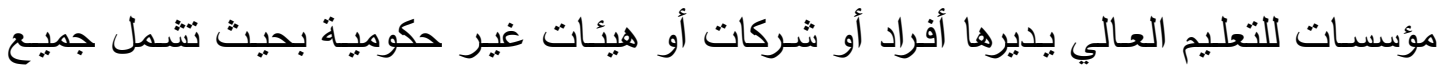

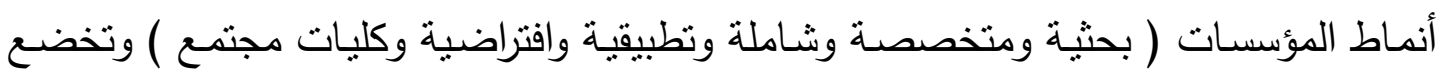

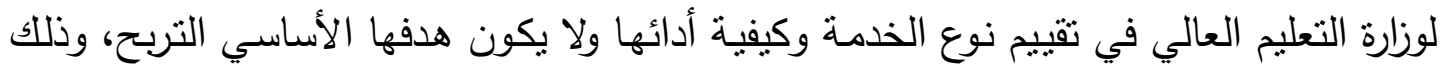

$$
\begin{aligned}
& \text { من أجل إحداث نقلات نوعية. } \\
& \text { سابعاً: حـــدود الدر اســــة: }
\end{aligned}
$$

اقتصر على دراسة للخصخصة في التعليم العالي من خلال (واقع الممارسات التطبيقية

الحالية للخصخصة، إيجابيات وسلبيات الخصخصة، والإجراءات المقترح تطبيقها)

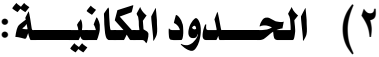

اقتصر على كلية إدارة واقتصساد بجامعة الملك عبد العزيز وكلية إدارة الأعمالالئل

r) الحسلدود الزمانيـة

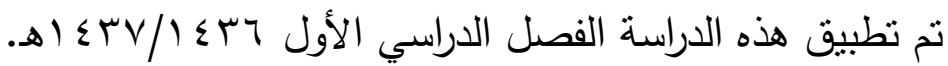

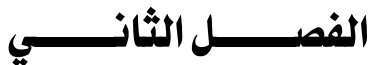

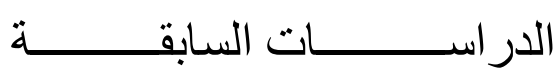

ـ دراسة الرباعي (11 (1) بعنوان"خصغة التعليم الجامعي في الأردن: دراسة ميدانية".

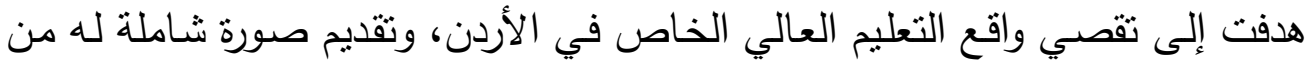

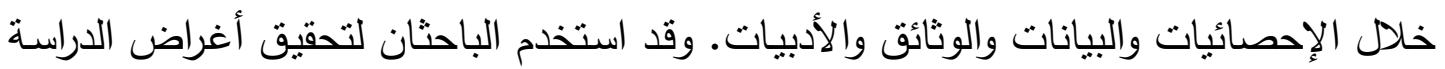

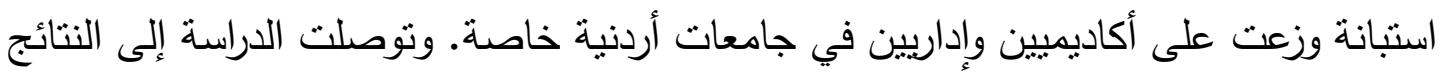

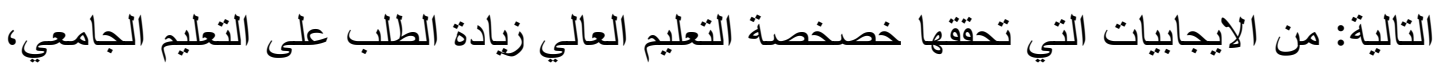

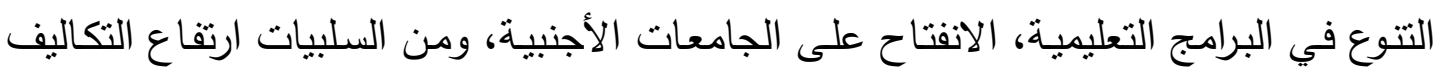


الدراسية، التركيز على المظهر وإغفال المضمون، حرمان محدودي الدخل من التعليم الجامعي،

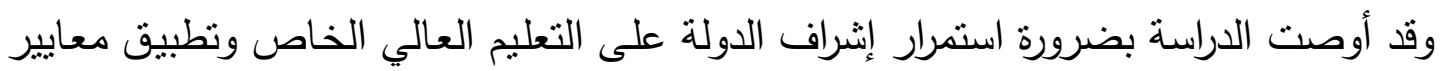

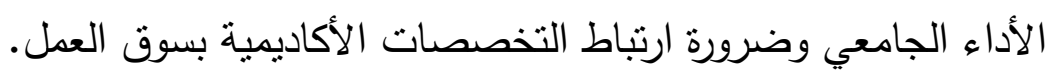

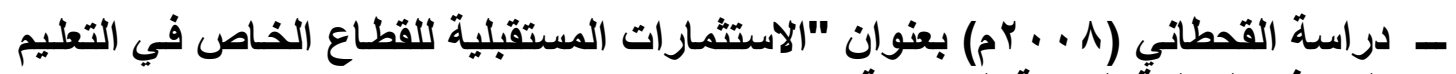
العام في المملكةً العربية السعودية"

هدفت الدراسة إلى التعرف على واقع استثمارات القطاع الخاص في التعليم العام، وكذللك

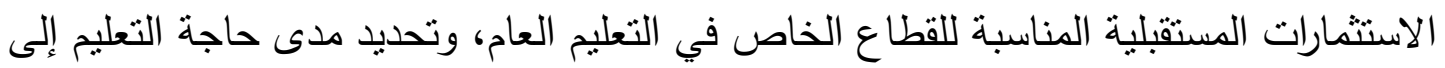

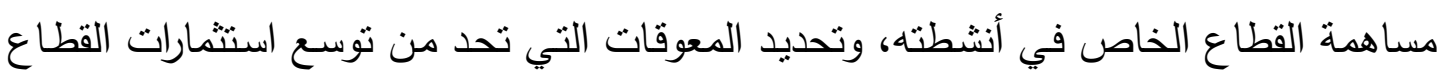

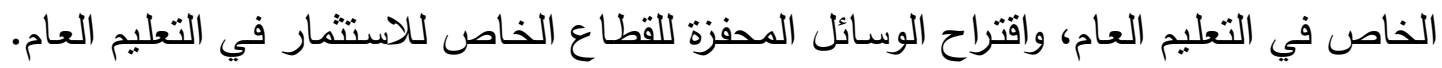

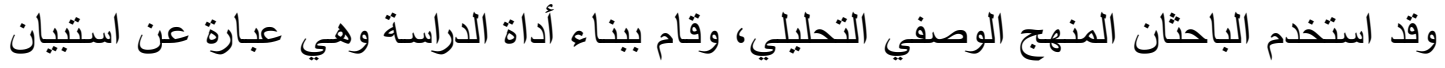

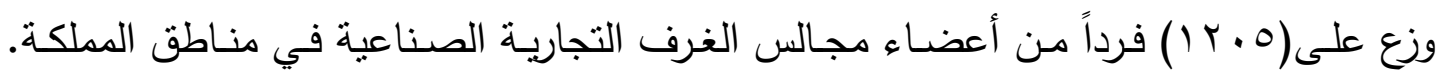

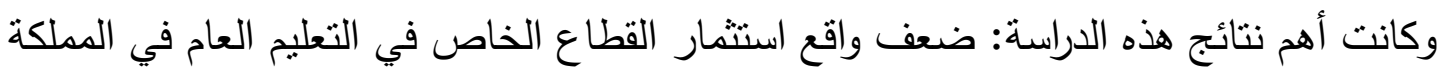

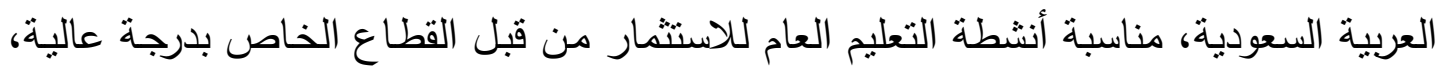

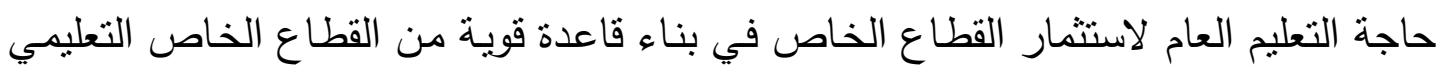

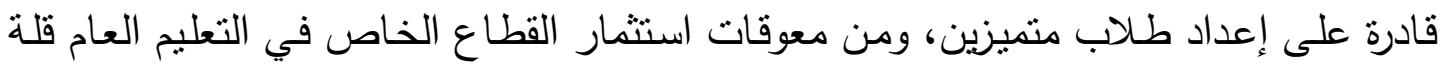

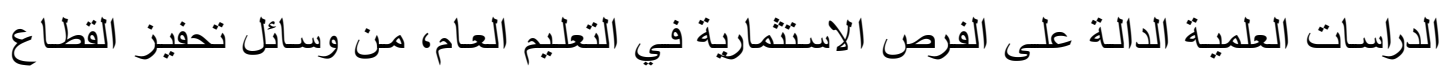

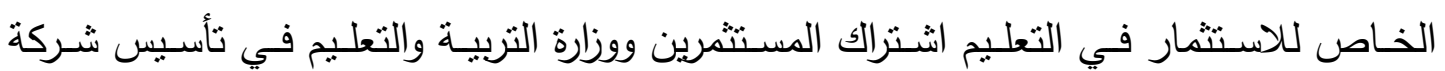
تعليمية.

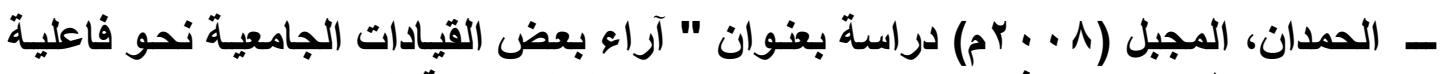

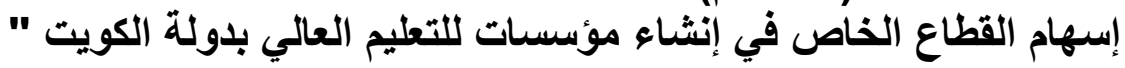

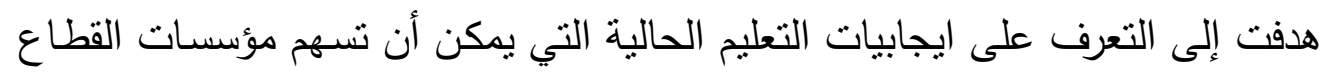

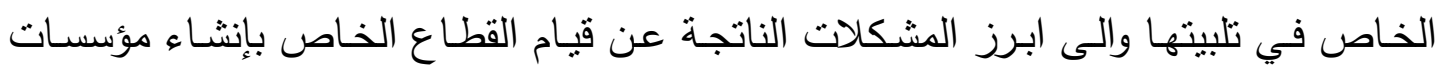

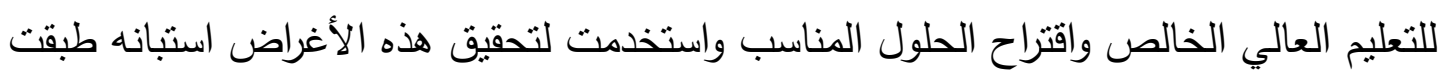

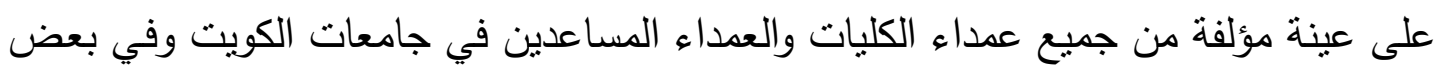

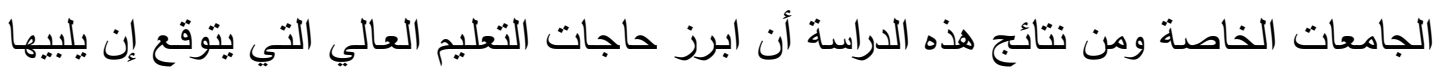

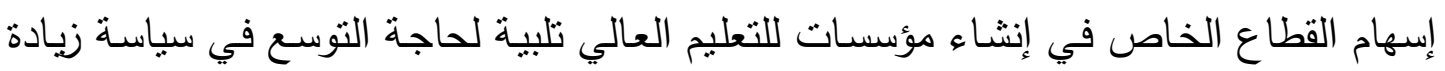

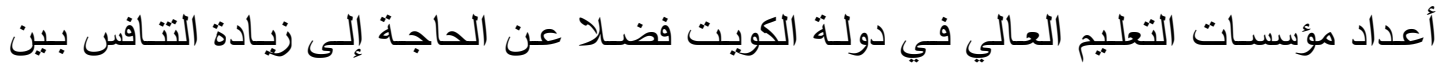

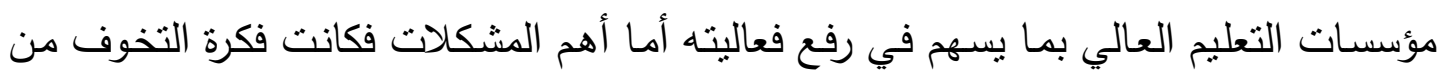


تحسل التعليم إلى تجـارة بـالتركيز على الجوانب الربحيـة وكذللك مشكلة تفـاوت المستويات الأكاديمية لمؤسسات التعليم العالي الخاص أما ابرز الحلول للحد من المشكلات التي قد تتتج من تتامي إنشاء القطاع الخاص لمؤسسات التعليم العالي فهي أن لا تقل مؤهلات أعضاء هيئة التدريس في مؤسسات القطاع الخالص عن مؤهلات نظرائهم في المؤسسات الحكومية والالتزام

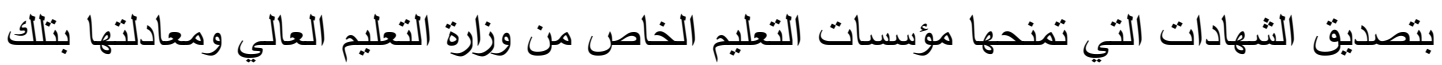

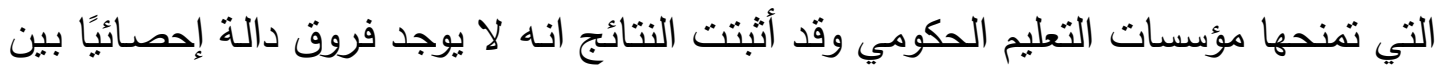

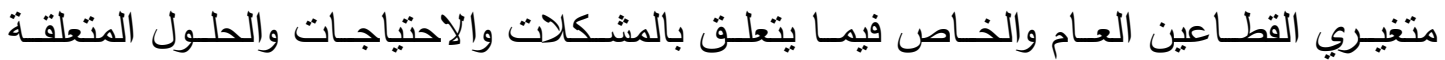
بالخصخصة في التعليم العالي.

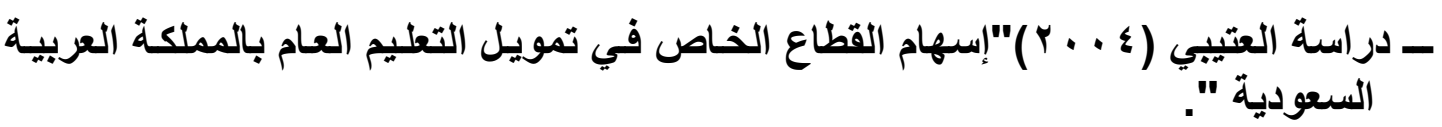
هدفت هذه الدراسـة إلى التعرف على مدى إسـهام القطاع الخاص في تمويل التعليم

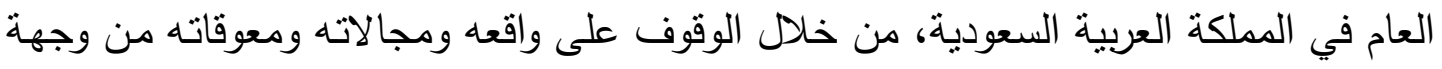
نظر مسئولي التعليم العام، ومسئولي القطاع الخاص في مدينة الرياض، إضـافة إلى التعرف

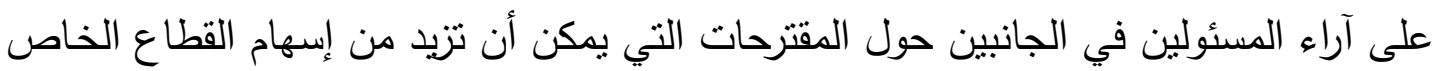

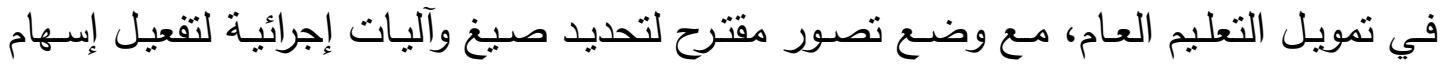

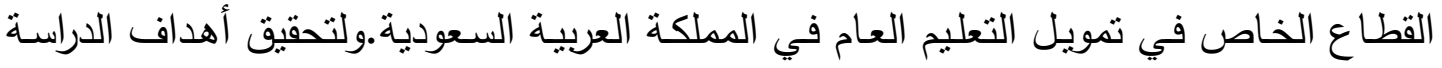
استخدم الباحثان المنهج المسحي الوصفي للتعرف على آراء المسئولين من خلال استبانة وزعت

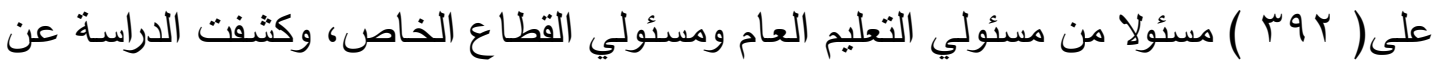

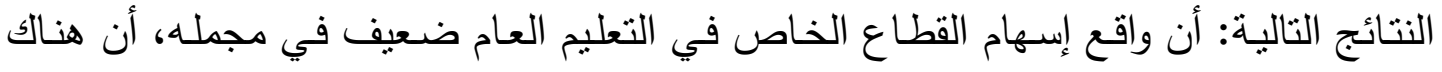

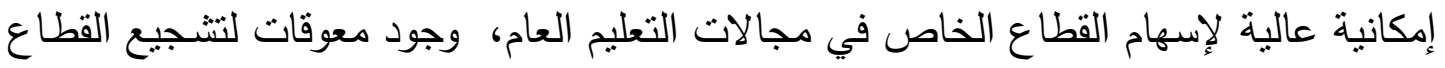

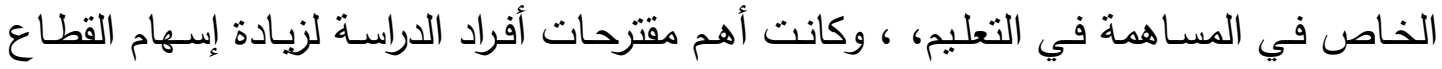

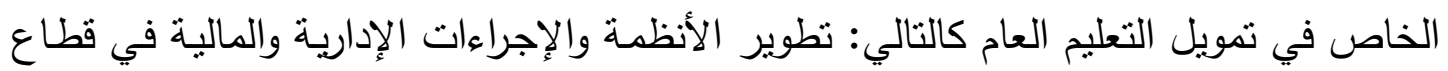

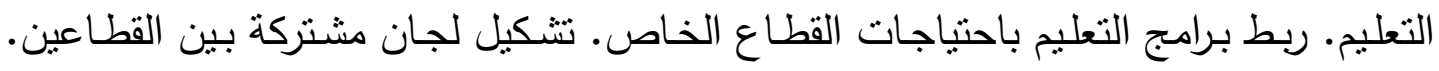

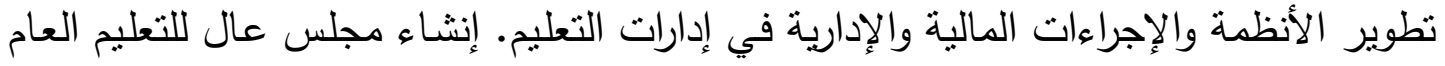

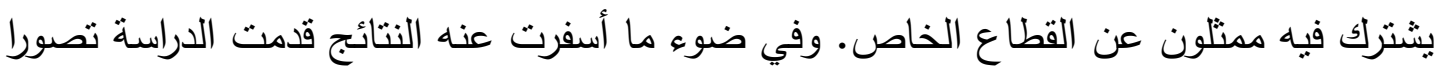
لزيادة إسهام القطاع الخاص في تمويل التعليم العام. 


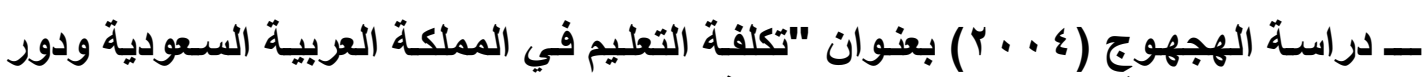

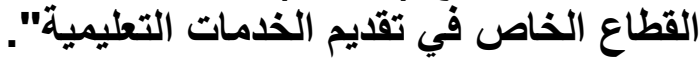

هدفت الدراسـة إلى التعرف على ماحققته المملكة العربيـة السـودية من الإنفاق والاستشمار

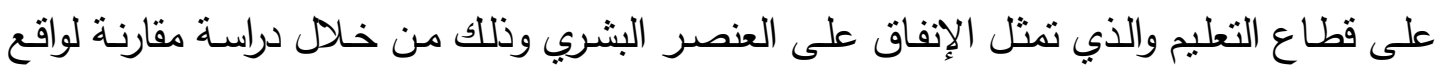
تكلفة القطاع التعليمي، ومعرفة مساهمة وتعاون القطاع الخاص في الاستثمار في قطاع الخدمات التعليمية للمراحل الدراسية دون الجامعي، وإبراز جوانب قوة وضـف تلك المسـاهمة. وقد استخدم الباحثان المنهج الاستتباطي التحليلي النظري للبيانـات الرسمية محلياً وعالميـاً وبعض المؤشـرات الاقتصادية والتعليمية، وتوصلت الدراسـة إلى النتائج التالية: تذبذب معدل نمو الإنفاق التعليمي في

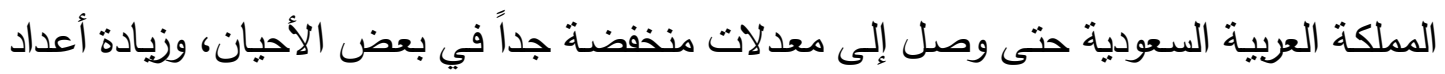
الطـلاب سـنوياً بمعدلات مرتفعـة جداً، و ضـعف مسـاهمة القطـاع الخـاص في تقديم الخدمات التعليميـة في مراحل التعليم العام بالإضـافة إلى وجود بعض المعوقات التتظيميـة والإداريـة والماليـة التي أدت إلى عزوف الكثير من المستثرين، وضعف الحوافز والدعم والتشجيع التي تقدمها الدولة للقطاع التعليمي الأهلي.

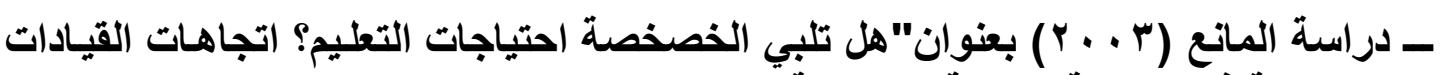

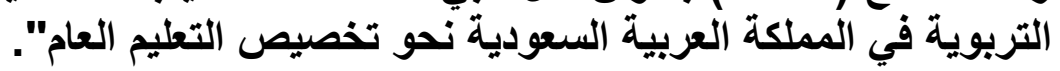

هدفت الدراسة إلى التعرف على اتجاهات القيادات التربوية في المملكة العربية السعودية نحو تخصيص التعليم العام، وقد عنيت هذه الدراسـة حول البحث عن ثناث تساؤلات وهي: ما

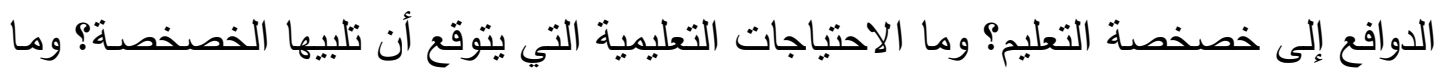
أبرز المشكلات التعليميـة أو الاجتماعيـة التي قد تتتج عن تطبيق الخصخصسة على التعليم العام؟. وقد اتبعت الباحثانة في هذه الدراسة المنهج المسحي الوصفي، وقد تمثلت أداة الدراسـة في الاستبانة والتي طبقت على عينة دن جميع أعضاء هيئة التدريس في أقسام المناهج وعلم النفس والتربية والإدارة التربوية، في كلية التربية في جامعة الملك سعود والبالغ عددهم (ر Y I ) عضواً، ومن جميع المشرفين التربويين والمشرفات في مكاتب الإشراف التربوي بأقسامها الأربعة

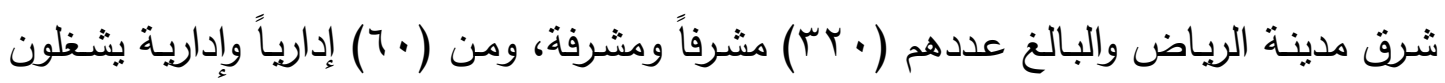
مناصب عليا في وزارة التربية والتعليم. وقد أظهرت نتائج الدراسـة: أن الدوافع إلى خصخصـة

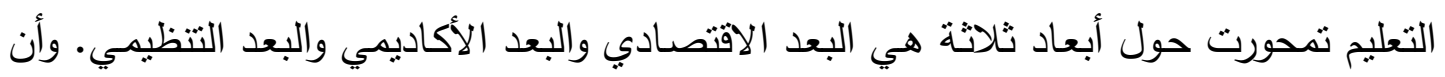

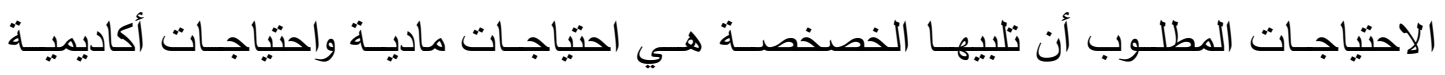

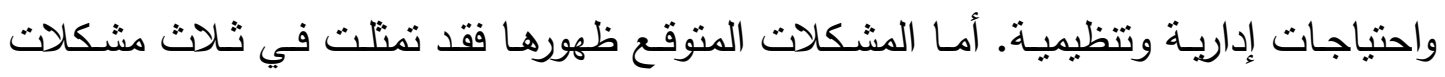
رئيسية هي: توقع ظهور التفاوت في المستويات الأكاديمية للمؤسسات التعليمية، وتوقع تسرب 
المعلمين المواطنين من مهنـة التعليم، وتحول المهنة التعليمية إلى ميدان للتجارة إذ ينصرف الاهنمام إلى الربح على حساب الجودة.

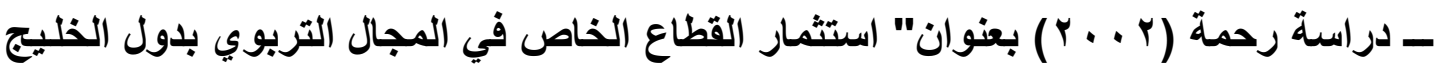

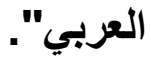

هدفت الدراسة إلى التعرف على سمات وايجابيات وسلبيات ومجالات استثمار القطاع

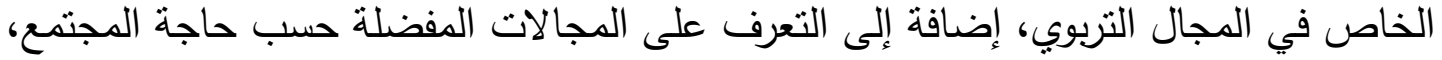

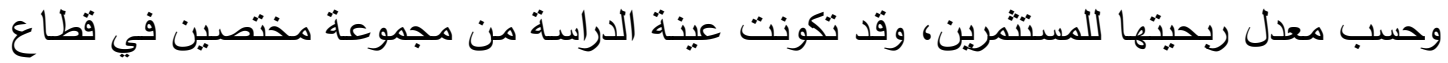
التعليم العام والعالي، ومستثمرين في مشروعات تعليمية غير حكومية، بلغ عددهم بـا ال فرداً

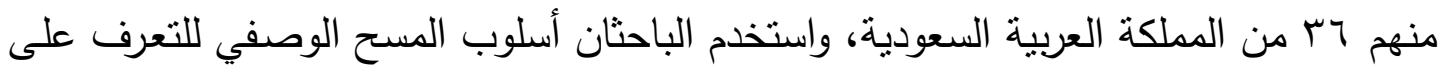

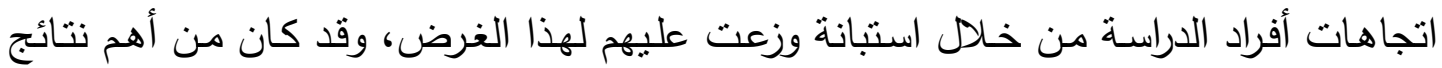

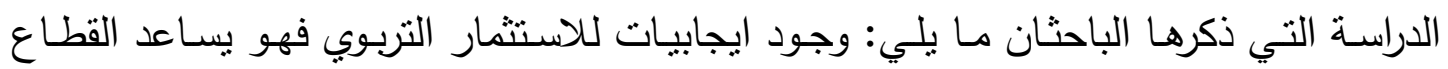

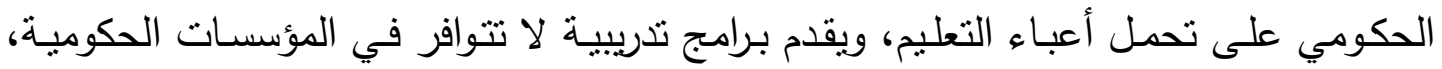
ويوجد أجواء من المنافسة بين المؤسسات التعليمية، ويوفر بيئات تعليميـة أفضل. لاستثمار

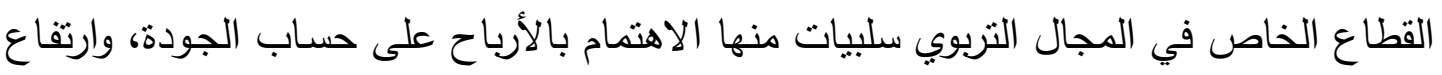

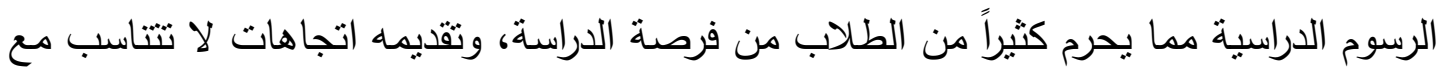

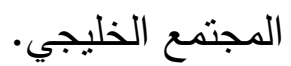

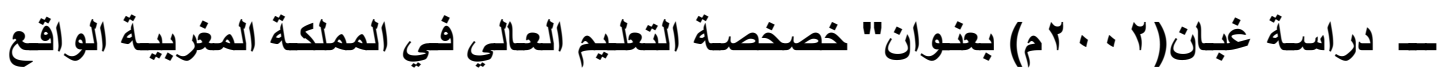
و والدروس المستفادة"

هدفت إلى عرض تجربـة التعليم العـالي الخـاص في المغرب من خـلال تتبع واقـع مؤسسات التعليم العالي الخاص وما نتج عنها وقد استخدم الباحثان المنهج الوصفي المسحي لهن وطبقت على عدد من المسئولين في وزارة التعليم العالي وأعضاء هيئة التدريس في الجامعات

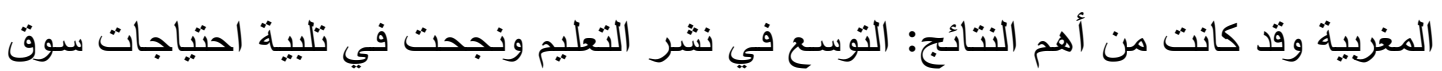

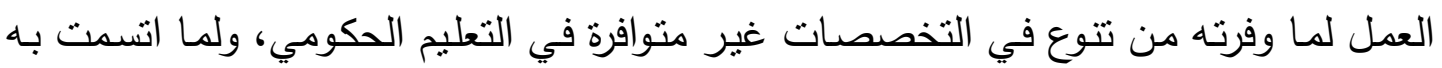
من مرونة وسرعة في التكيف مع منطلبات السوق ولتركيزها على الجانب التطبيقي والتدريبي

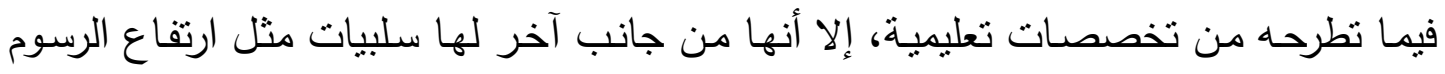

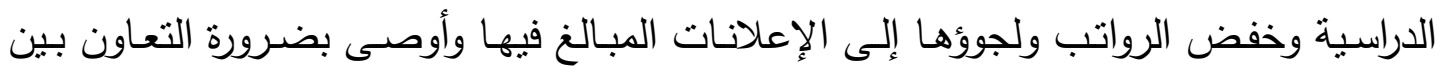
القطاعين العام والخاص.. 
ـ دراسة المطرفي ( . . . Y ) بعنوان"مدى مساهمة القطاع الخاص في التعليم العالي بالمملكة

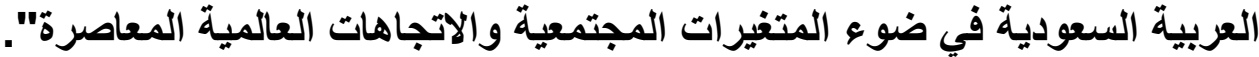

هدفت الدراسـة إلى التعـرف على واقـع إسـهام القطـاع الخـاص في المملكـة العربيـة

السعودية في ضوء المتغيرات المجتمعية والإتجاهات العالمية المعاصرة، وقام الباحثان باستخدام

المنهج الوصفي التحليلي، وقد وزعت على (I I ) فرداً (9V) منهم من القطاع الحكومي

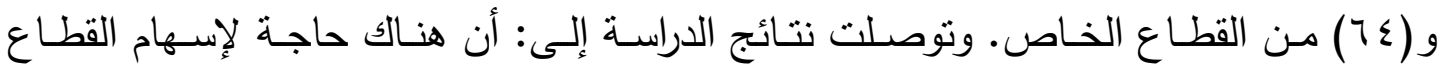
الخاص في التعليم العالي وذلك بسبب ضـف قنوات الاتصـال بين مؤسسـات التعليم العـالي والقطاع الخاص، واعتماد تمويل التعليم العالي على الميزانية الحكومية، وقلة الاهتمام بالأنشطة البحثية التي تسهم في حل مشكلات القطاع الخاص، وعدم استجابة مؤسسات التعليم العالي لمتغيرات العصر ومتطلباته.

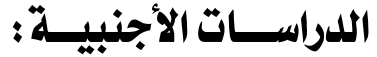

ــ دراسـة بالانياتدي (Palaniandy, 2013) بعنوان: " الآثار المترتبـة من التربح في

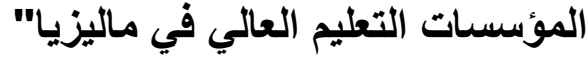

تهدف الدراسة إلى معرفة إذا ما كان الطلبة يعاملون كعملاء مستهدفون لجني الأرباح أم أنهم يعاملون كطلبة سواء وما يميزهم هو الكفاءة والقابلية للتعلم في مؤسسات التعليم العالي في ماليزيا. فقد أجرى الباحثنان في إعداد هذه الدراسـة العديد من المقابلات مـع من يدرسون الماجستير والدكتوراه بالإضـافة إلى الزيارات الميدانية لبعض هذه المؤسسات. وأظهرت الدراسـة أن استقبال الأعداد الهائلة من الطلبة هو بداعي زيادة الأرباح بغض النظر عن الكفاءة والقدرة على القيام بالأبحاث والدراسات؛ وذلك مما يؤثر سلبًا على التعليم.

ــ دراسـة هيلر وجيجر (Heller\& Geiger,2011) بعنوان: "التوجهات الماليـة في

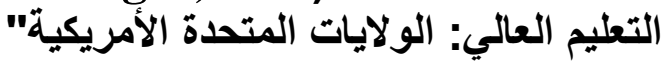

تهدف الدراسـة لمعرفة التطورات المتعلقة بتطبيق نظـام الخصخصـة في التعليم العالي وعائداتها على الولايات المتحدة الأمريكية، بحيث استخدم الباحثان المنهج الوصفي عن طريق إعداد استبانات. وقد أظهرت نتائج الدراسة أن تطبيق نظام الخصخصة في التعليم العالي شكل مصدر تمويل عالي للولايات المتحدة الأمريكية، كما أظهرت نتائج الدراسـة ضرورة إعادة النظر فـي طريقـة تمويـل التعلـيم العام مـن خلال تعبئة موارد مالية إضـافية تـدعم النفقات التعليمية الحكومية المتزايدة. 
ــ دراسـة بـابو (Babu,2011) بعــوان:" خصخصـة التعليم العـالي في الهنــ: تحديات

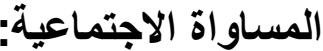

"تهذف هذه الدراسة إلى التعرف على أثر تطبيق نظام الخصخصة في التعليم العالي

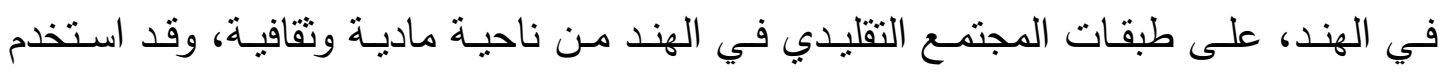

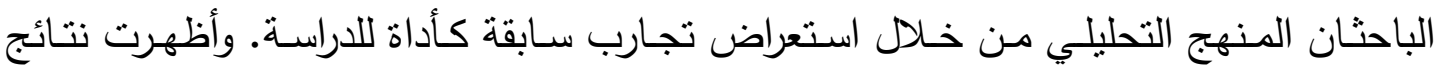
الدراسة إلى أن تطبيق نظام الخصخصة يؤدي إلى تمركز الاقتصاد بأيدي صانعي السياسات

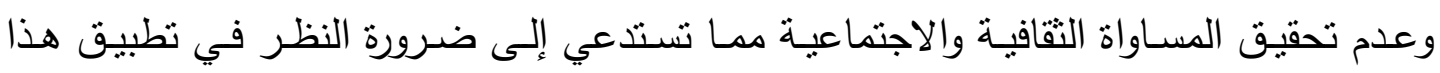

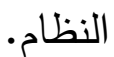

ـ دراسة تود (Todd,2008) بعنوان: "أثر الخصخصة الربحية على التعليم العالي في ولاية ماساشوستس دون

هدفت الدراسـة إلى بيـان أثز الخصخصـة الربحيـة على التعليم العالي " تجربـة ولايـة ماساشوستس" استخدم الباحثنان الاستبانة والمقابلة وطبقت على عينة من الخبراء في المؤسسات

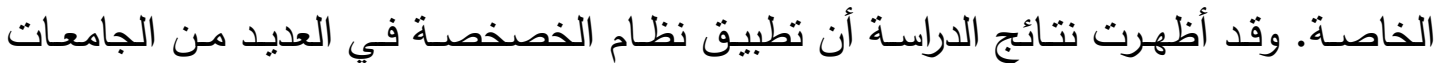
والكليات شكل مصدر تمويل ذو دخل مرتفع ساعد في التظلب على العجز المالي والمحدودية

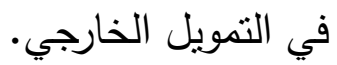

ــ دراسـة دورتـي (Dougherty.2004) بعـوان: "تمويـل التعليم العـالي في الولايـات المتحدة: الهيكل والتوجهات والقضايا ل

تهـدف الدراسـة إلـى عـرض التغيـرات الحاصـلة في التمويـل وكيـف اسـتجابت لهـا

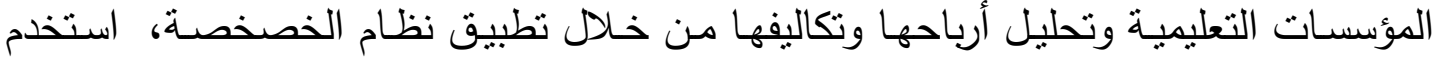

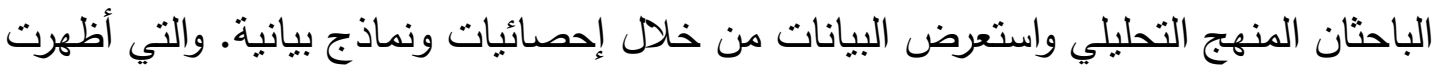
نتائجها مجموعة من التغيرات السلبية للتعليم بالنسبة إلى الطلبة كما أن هذه المؤشرات تدعو

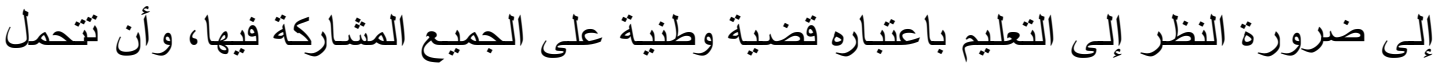
مسؤولياته الجهات الحكومية والخاصة.

ـ دراسة ماركوس (Marcos, 2003) بعنوان: "خصخصة التعليم العالي في أسبانيا "

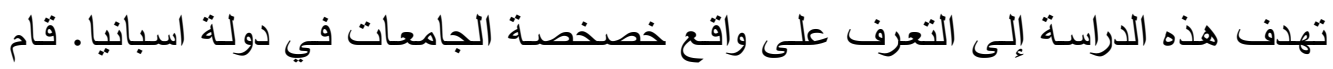

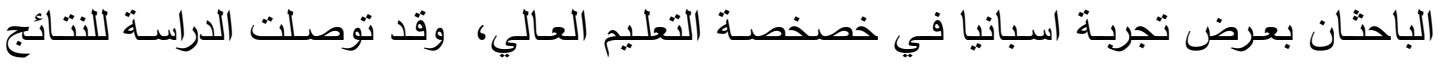

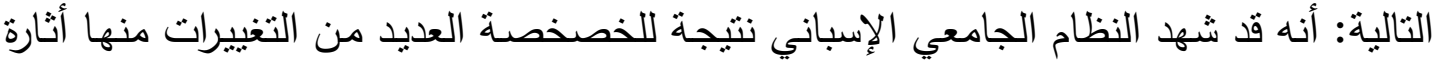

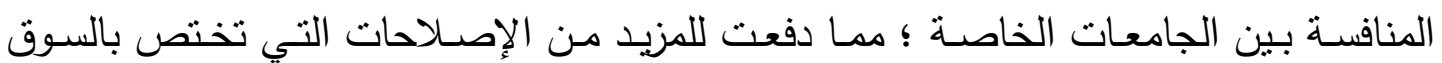


والخصخصـة لبعض الجامعـات الحكوميـة، وحريـة الطـلاب لاختبـار جـامعتهم، وسياسـات التوظيف، وتقييم الجودة والمساءلة العامة، تخصيص أموال للبحث والتصنيف العالمي.. كما

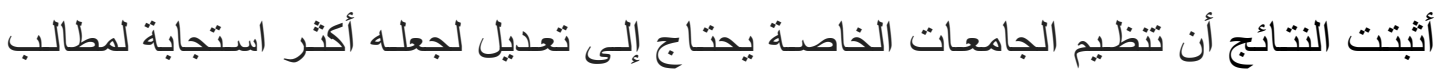
السوق والمستهرلك.

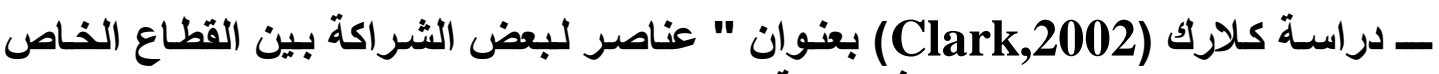

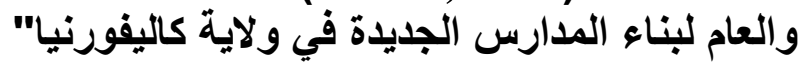

هدفت الدراسة إلى التعرف على عناصر المشاركة الناجحة بين القطاع العام والخاص لبناء الددارس الجديدة في ولاية كاليفورنيا والعوائق التي تقف في طريق إنجاز هذه الثراكة،

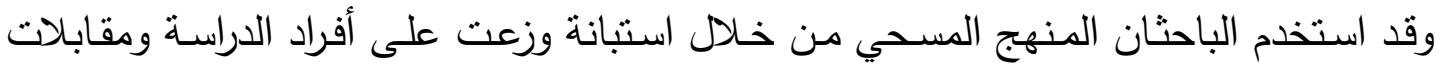
شخصية وقد تكونت عينة الدراسة خمس شركات وست مناطق تعليمية في ولاية كاليفورنيا كانت بينهم شراكة لإنشاء مدارس عامة في الولاية، ، وقد قام الباحثان بتحديد ستة عناصر تؤدي إلى

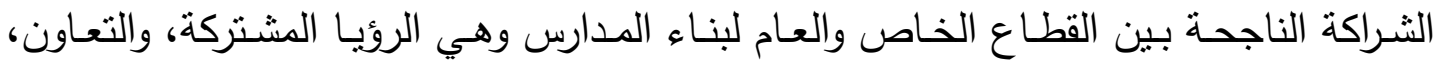

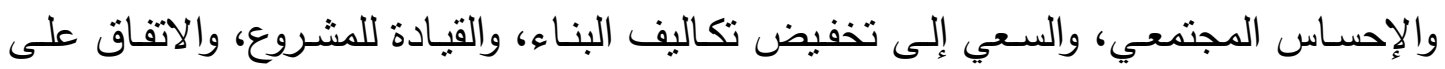

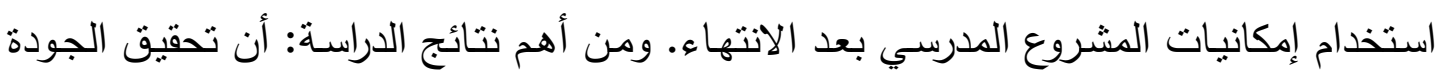

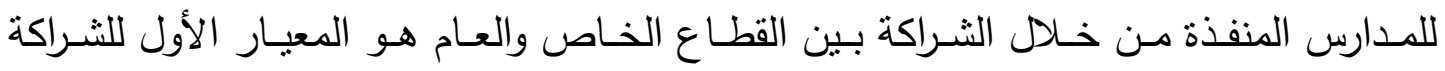

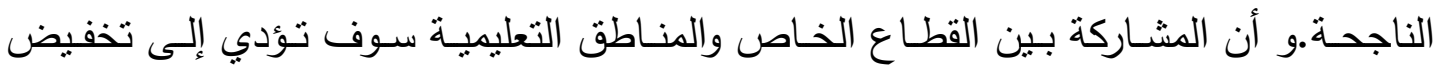
تكاليف بناء المدارس. ويجب أن تتوافر في ممنلي القطاعين الخبرة والقدرة على اتخاذ القرار. التعليق على الدر اسات السابقة:

تتوعت الدراسات السابقة مابين محلية، وعربية، وأجنبية تختلف من حيث الموضوعات

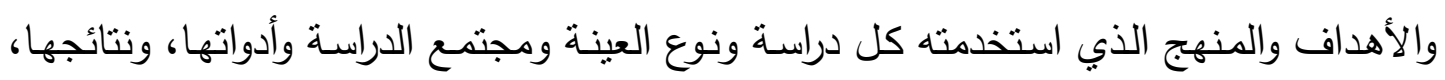

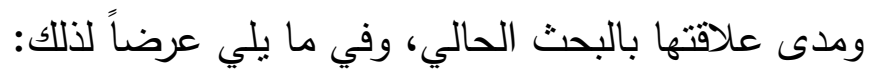
ا ـ منهجية الدراسات السابقة وأدواتها: " اختلفت الدراسة الحالية مع الدراسات السابقة في تتاولها للمنهج حيث استخدمت الدراسة الحالية المنهج الوصفي المسحي المقارن. - اتفقت الدراسة الحالية مع معظم الدراسات السابقة في الأداة المستخدمة وكانت الاستبانة

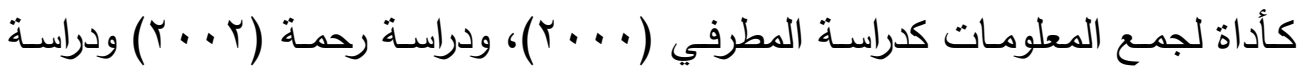

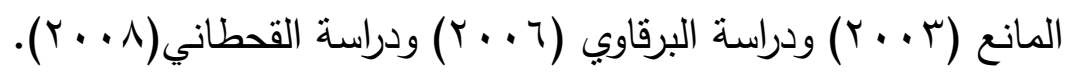

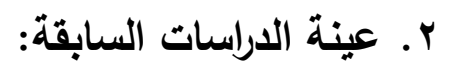


• اختلفت عينـات الدراسـات السـابقة من باحث لآخر حسب نوع الدراسـة والهدف منها فنملت عمداء الكليات وإداريين وأعضاء هيئة تدريس في جامعات حكومية وجامعات

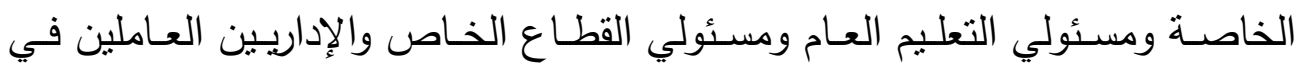

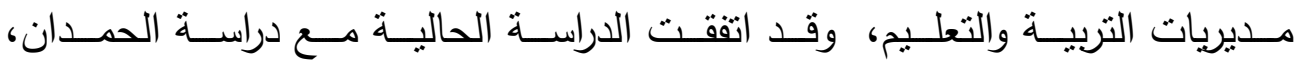

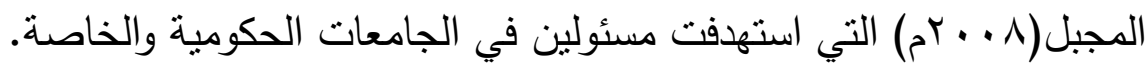
" واختلفت عينة البحث الحالي عن الدراسات السابقة حيث شملت أعضاء هيئة التدريس

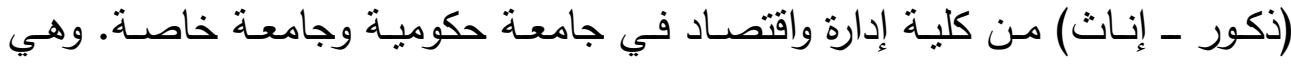

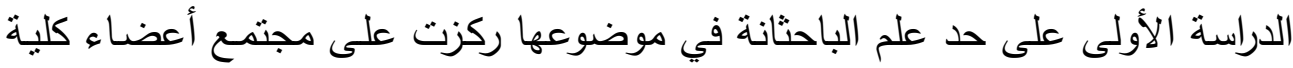
إدارة واقتصاد من جامعة خاصة وحكومية في الاستجابة على أداتها. r. أهداف ونتائج الدراسات السابقة:

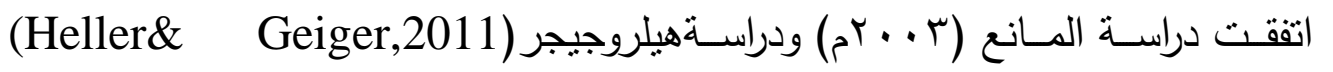

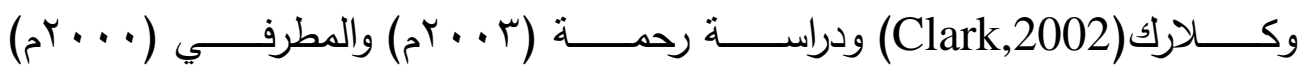

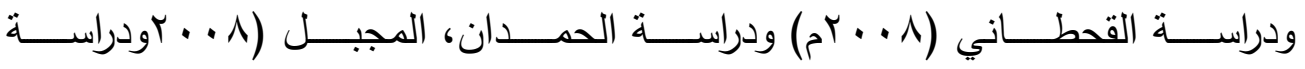

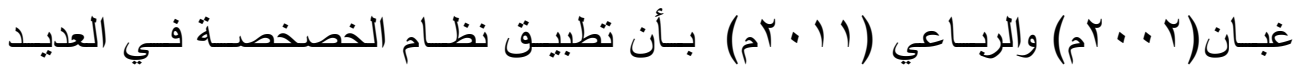

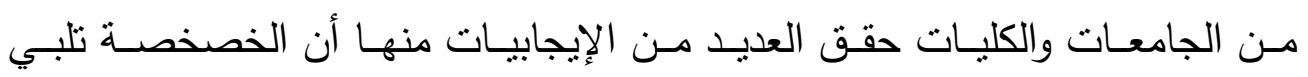

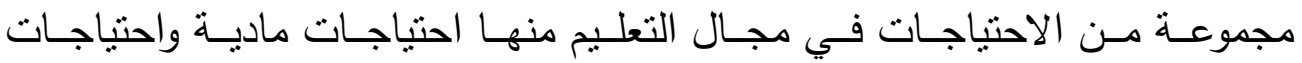

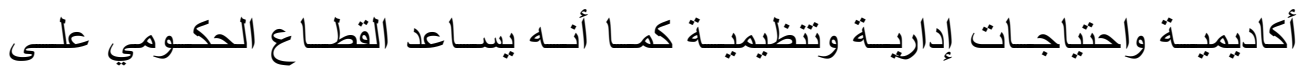

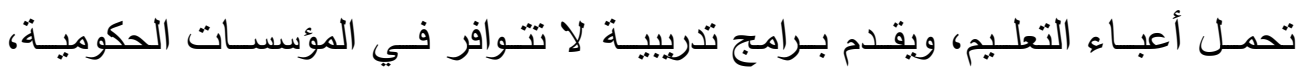

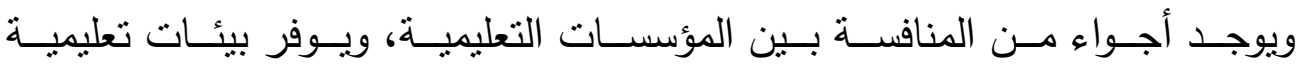

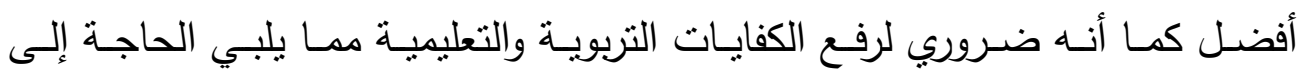

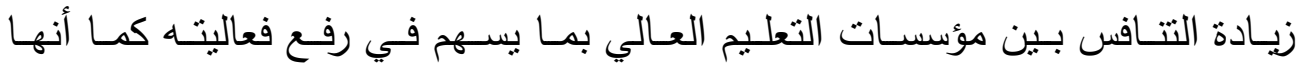
تسـاعد على الاسـتقال الإداري ونسـاعد على تحسـين ظـروف الإختبـار والتعيـين

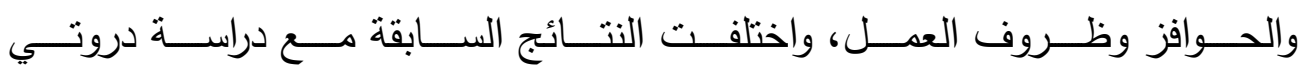

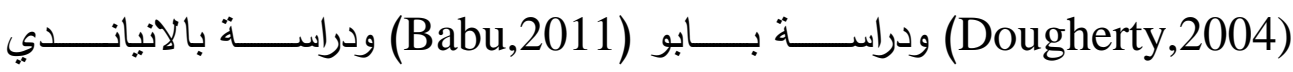

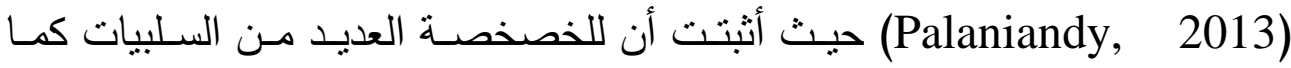

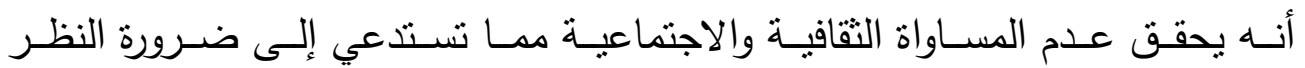

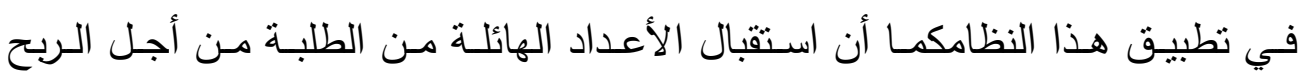

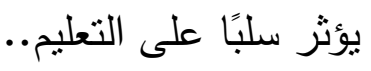

\section{Y19}




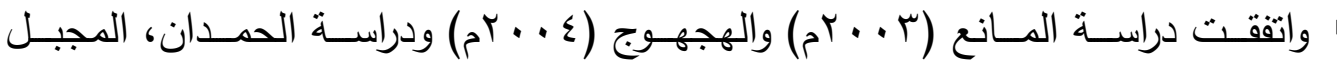

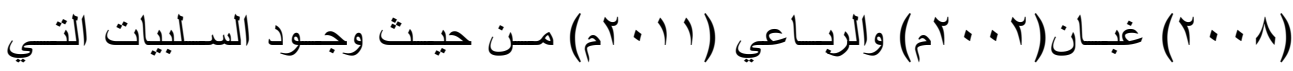

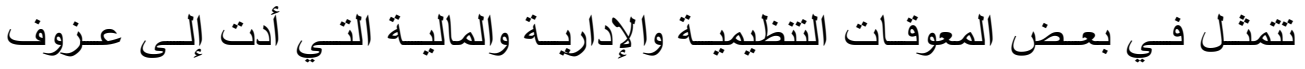

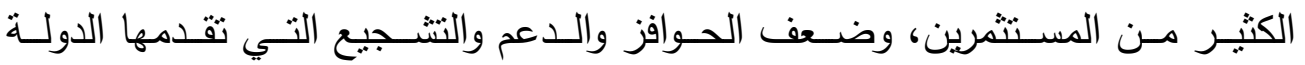

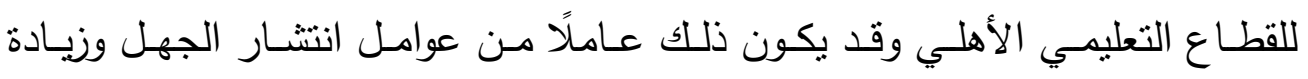

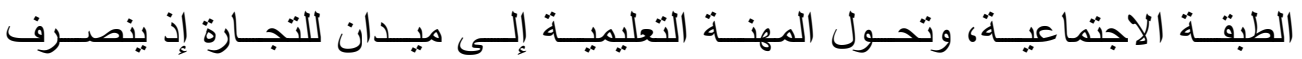

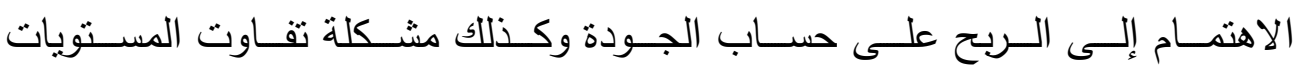

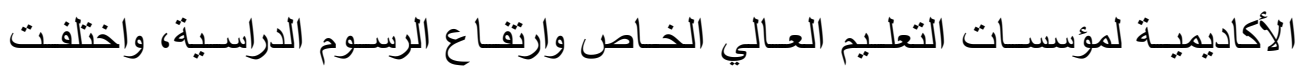

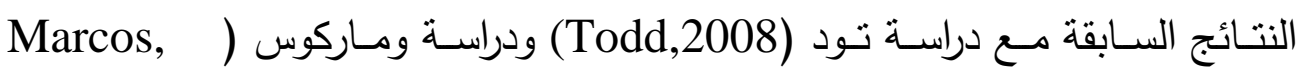

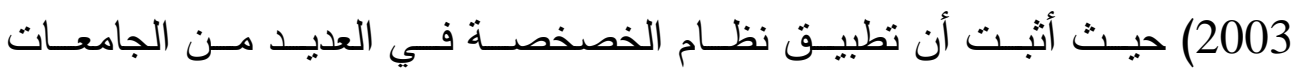

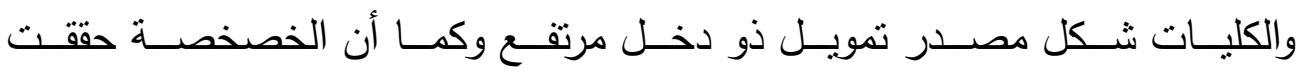
العديد من التغييرات منها أثارة المنافسة بين الجامعات الخاصة.

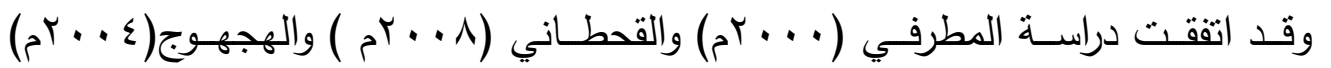

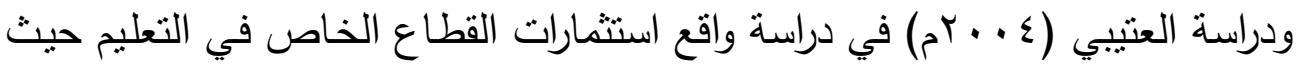

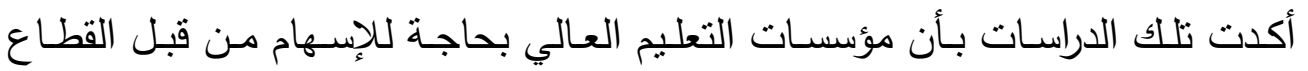
الخاص لنطويره وليحقق له مواكبة لمتغيرات العصر على ضعف واقع استثمار القطاع

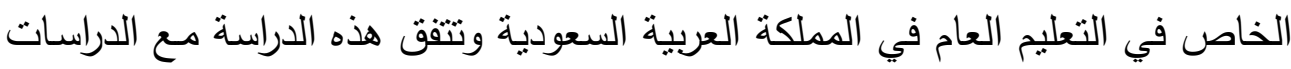

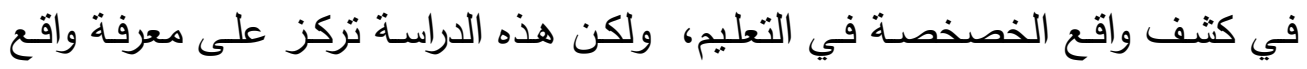

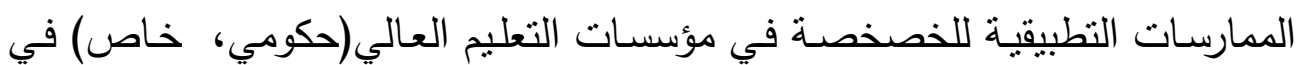

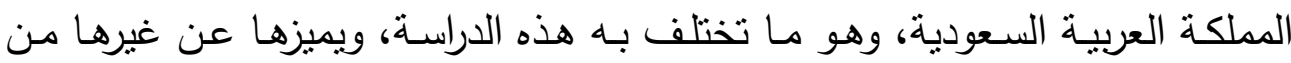

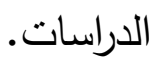

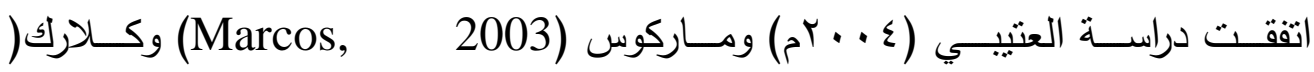

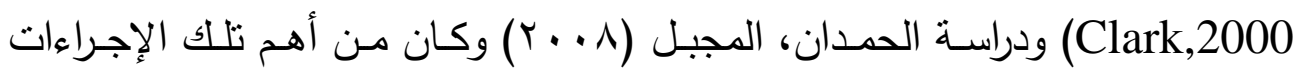

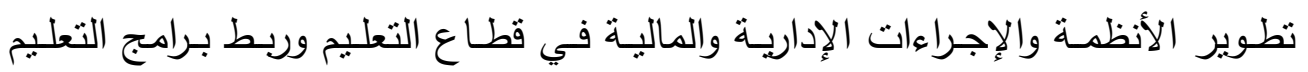

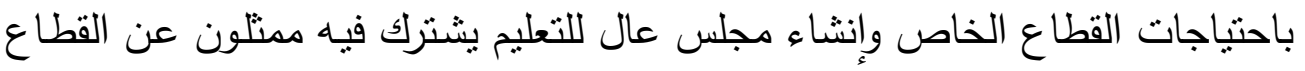

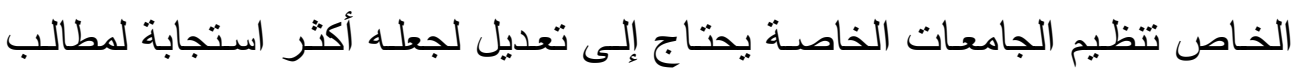


السوق والمستهلك وضرورة تعزيز العلاقة بين القطاع العام والخاص لتحقيق شراكة

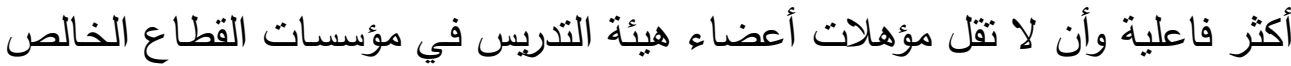

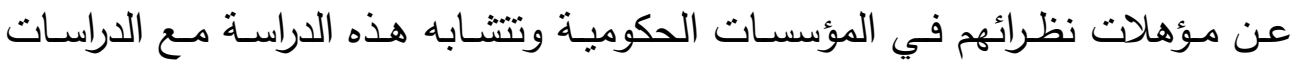

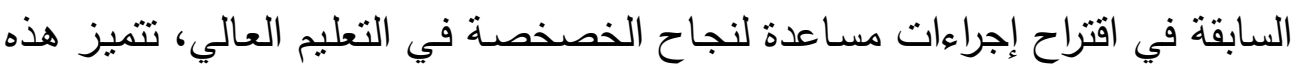

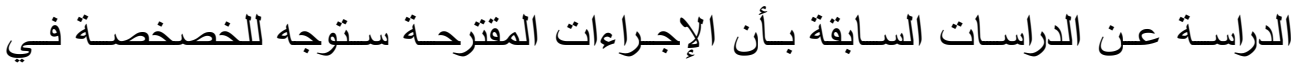
مؤسسات التعليم العالي من خلال تجارب محلية ودولية وعربية. " اختلفت دراسة الحمدان، المجبل (1 . . rم) بدراسة فروق بين أفراد العينة تبعًا لمتغير

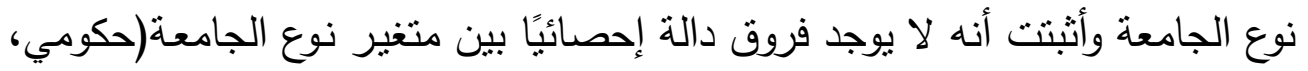
خاص) فيما ينعلق بالايجابيات والمشكلات والاقتراحات. وقد كان للاراسات السابقة دور في إثراء الجانب النظري للبحث الحالي، وفي تصميم

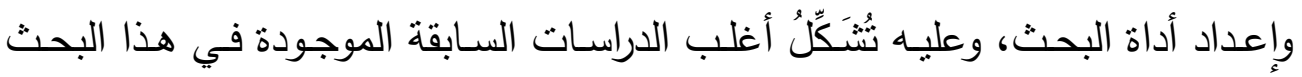
عنصرًا مهمًا في تحسين مستوى البحث الحالي.

\section{الفصـــل الثالـــــث}

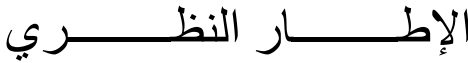

يتتـاول الباحثنان في هذا الفصـل مـن الدراسـة عرض مـوجز لبعض جوانب العمليـة

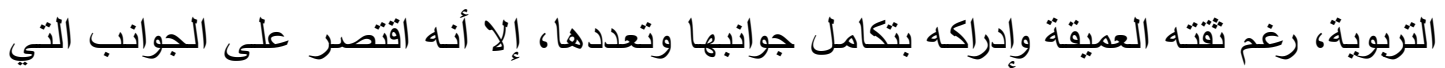
رأى اتصالها الوثيق بموضوع دراسته

\section{المبحث الأول : الخصخصة مفهومها وأنماطها وإيجابياتها وسلبياتها.}

من الضروريات تقديم مدخل عن الخصخصة كأحد محاور الإطار النظري عن الخصخصة

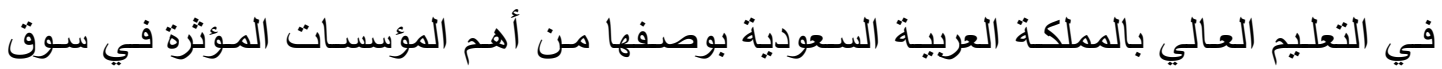

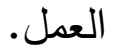

\section{خصخصة التعليم العالي}

يعد التعليم العالي من إحدى الوسائل المؤثرة والفعالة في حركة التقدم البشري، بحيث

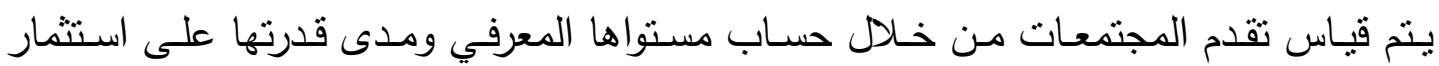

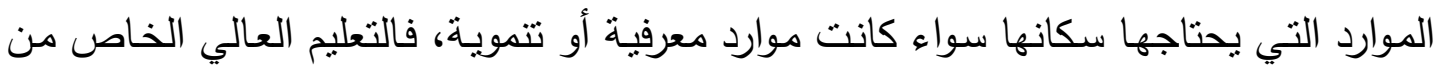

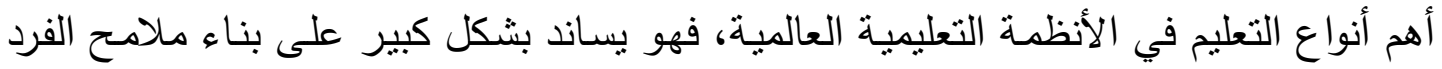


وسماته، وغرس القيم والمقومات في الإنسان، والتي يتم اعتمادها في بناء الثخصية المتوازنـة والمتكاملة.

إلا أن معظم الـدول والبلـدان العالميـة قد تواجـه بعض الاختلافـات والمشـكلات في في

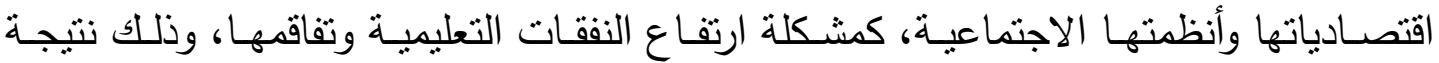
للتغيرات الاجتماعية والاقتصادية والصحية، مما عمل على زيادة الطلب الاجتماعي على التعليم وارتفاع أعداد المسجلين في الجامعات الحكومية، فالتعليم بات جزء لا بستهان بـه من الإنفاق الحكومي للدولة حيث تتساوى في ذلك الدولة الغنية والغير غنية، وبذلك أصبح التعليم يواجها مأزق كبير في تكاليف الإنفاق عليه من قبل الدولة بشكل يجعل الدولة غير قادرة على تقديم

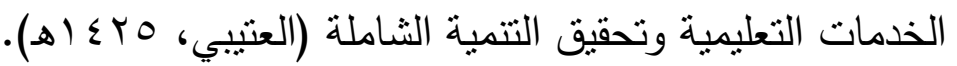
ويرى بـاجي(Bajaj.2012 ) أن التعليم العالي يحتاج إلى تتمية اقتصـادية واجتماعيـة

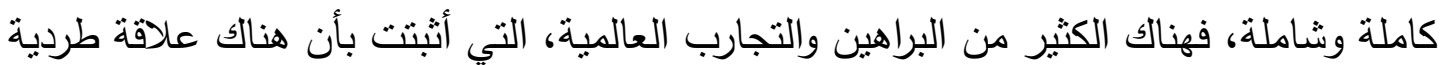
ما بين التعليم العالي والنمو الاقتصادي والاجتماعي، ومن أجل تللك العلاقة فقد اهتمت الدول

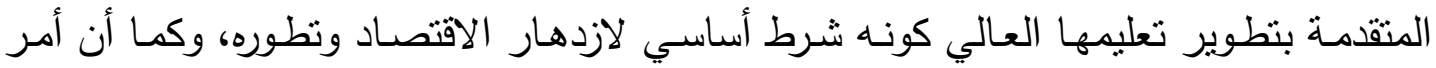
تطوير التعليم العالي ضرورياً للدول المتقدمة، فأنه أكثر ضرورةً في الدول النامية. ويؤكد مـاري وآخرون(Mary et al,2013) بـأن الهدف من تطوير التعليم العـالي الخاص وتحسينه، يبـأ بتحفيز الاستثمار وتشتجيعه ضـن مجال التعليم العـالي، وذلك عبر تشـيع القطاع الخاص والمؤسسات الغير حكوميـة، والتتويع في مجالات الاستنمار وصيغه، حيث يتم ذلك من خلال الدخول إلى صيغ الإنتاج العلمي وتطوير سوق العمل، مـ ضرورة استمرار الجامعات في مهامها والحفاظ على نوعية التعليم من خلال دعم تمويلها والعمل على لعى تضيق فجوة الإيرادات والنفقات عبر خصخصة مؤسسات التعليم العالي. وهذا مـا بيينه أوليفر وآخرون إلى أن العقود السـالفة اتخذت منحى عالمي دعا إلى مؤى خصخصـة الكثير من الخدمات في المؤسسـات الحكوميـة، لذا ظهرت الخصخصـة باعتبارهـا إحدى الحلول المناسبة لعلاج الخلل الذي يواجه الهياكل الاقتصادية والعمل على الارتقاء بها ورفع مستوياتها الكفائية والأدائية، وأن التعليم العالي شهد بعض تلك التوجهات في الخصخصة بعدما رفعت أصوات المثقفين والتي نادت بوجوب تخلي الدولة عن مشروعيتها السابقة وذلك بهاب نظراً لقلة مواردها ومحدوديتها وزيادة أعبائها، وهذا مـا عمل على دعوة القطاع الخاص في المساهمة في تحمل أعبائها (OLIVEIRA et al,2009). وقد شهدت عملية خصخصة التعليم العالي نمواً ملحوظاً في الآونة الأخيرة وفي العديد من دول العـالم، حيث باتت مؤسسـات التعليم العـالي الخاصـة تسيطر على نصف مؤسسـات 
المجتمع فقد احتلت ، 0\% مـن مؤسسـات التعليم العـالي في بعض البلدان العالميـة ككوريـا

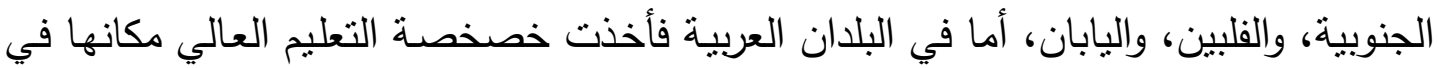

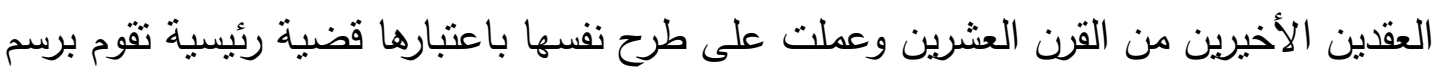

$$
\text { مسارات التعليم الجامعي وملامحه (البرقاوي، } 7 \text { × . ؟ ). }
$$

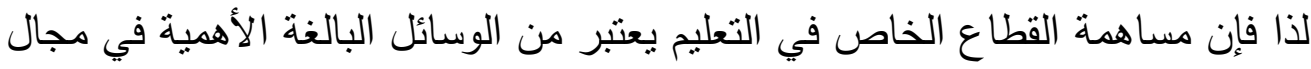

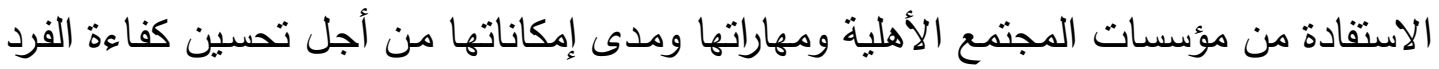

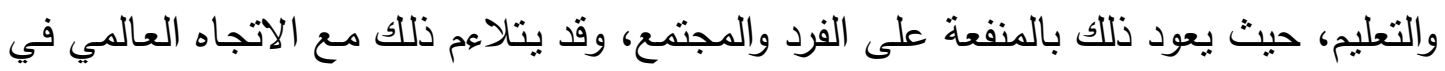

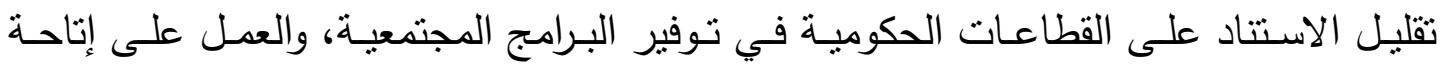

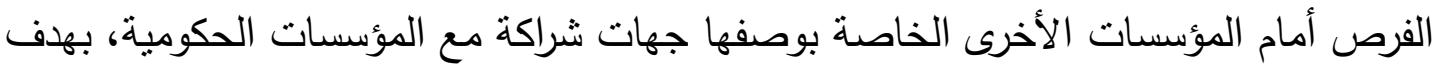
تحقيق التتمية والتقدم، لذا فإن التعاون ما بين قطاعات التعليم الحكومي والقطاعات الخاصـة

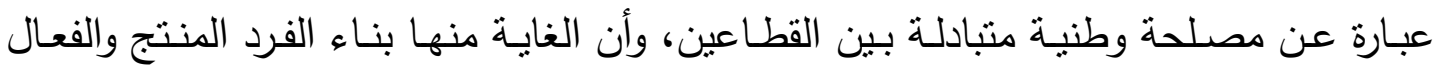

$$
\text { والمؤثر في المجتمع (العتيبي، وبارة عن أه). }
$$

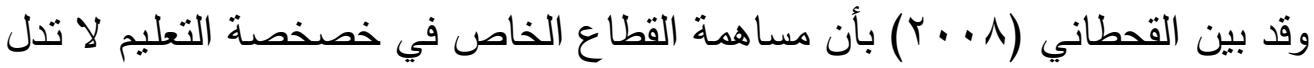

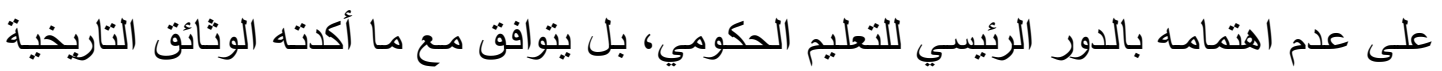

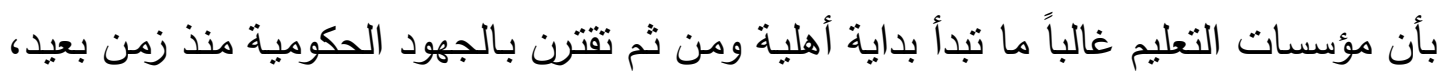

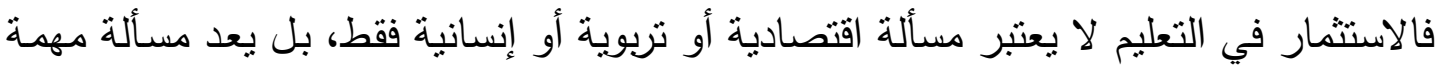

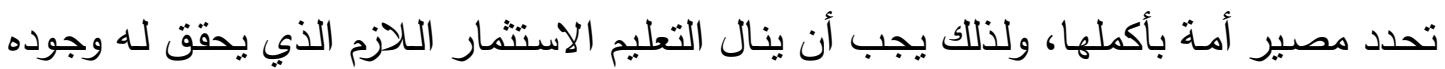

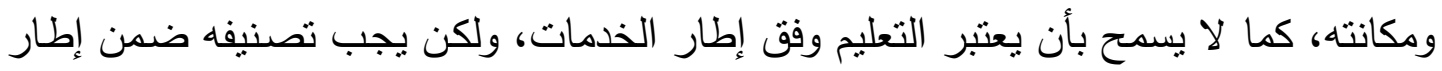

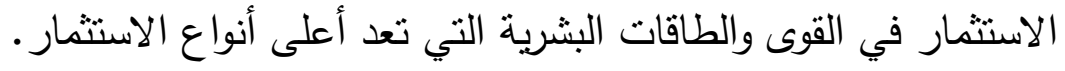
وقد ظهرت بوادر التوجه نحو خصخصة التعليم العالي في المملكة العربية السعودية،

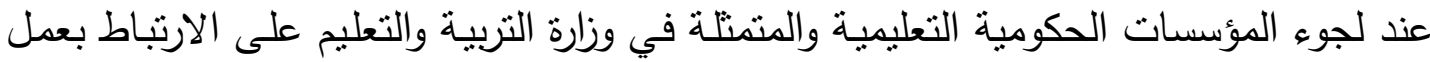

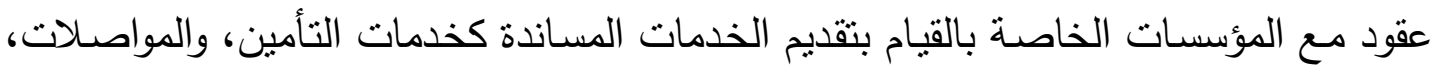

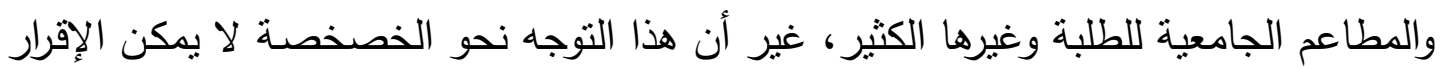

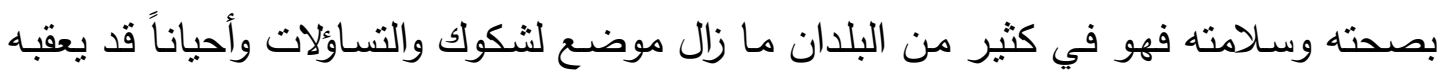

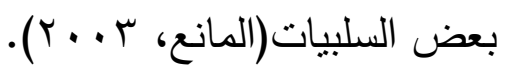

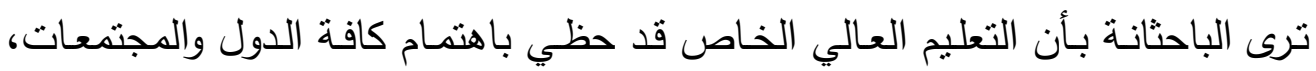

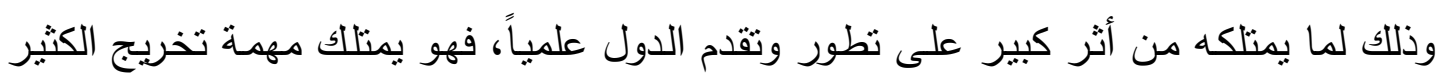


من الكوادر البشرية التي تعمل على تتمية الوطن والمجتمعات، وهذا ما دعا القطاعات الخاصة

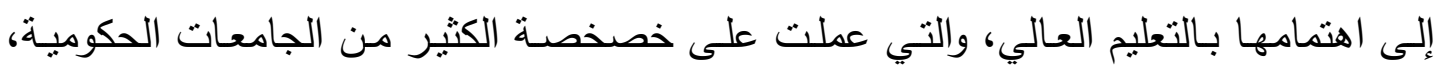
وذلك إيماناً منها بوجوب نوفير التعليم لكل فرد، ومدى حاجة الدولة لتهيئة كوادر بشرية مؤهلة لبناء المجتمع وتحقيق أهدافه التتموية.

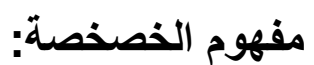

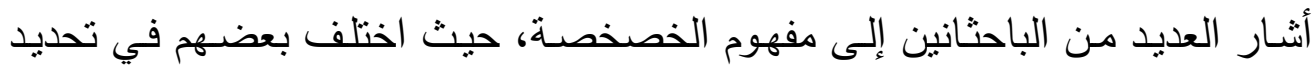

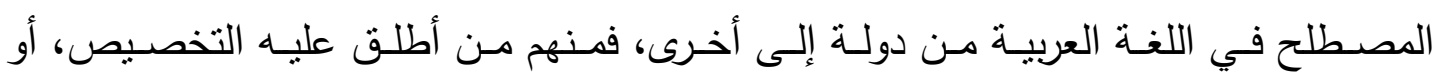

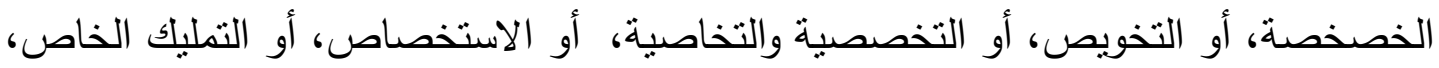

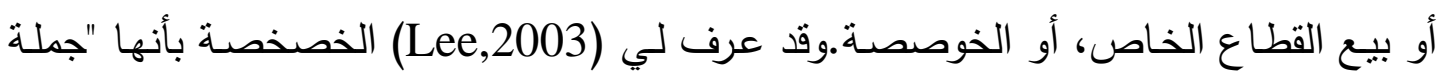

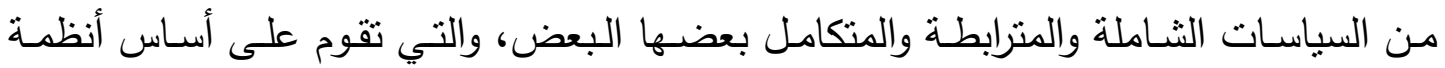

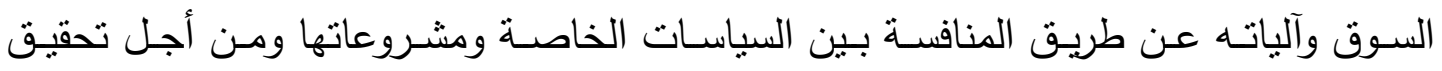

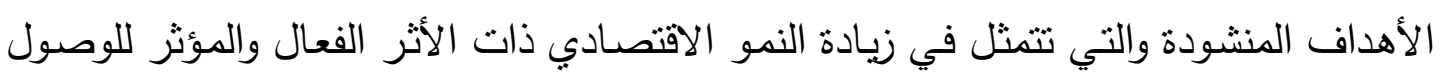
إلى تحقيق مبدأ العدالة الاجتماعية".

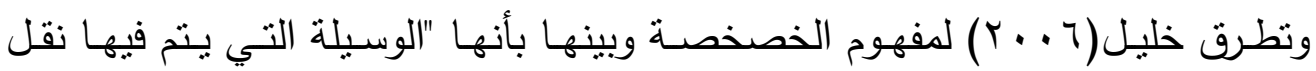
أنثطة المؤسسات التعليمية الحكومية العامة إلى القطاع الخاص من أجل تحقيق مستوى عالٍ في نتغيل المؤسسة التعليمية وإدارتها".

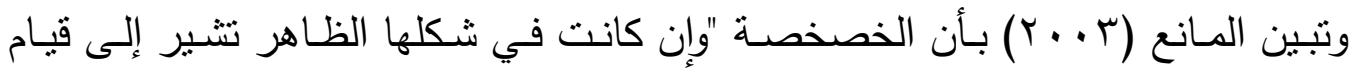

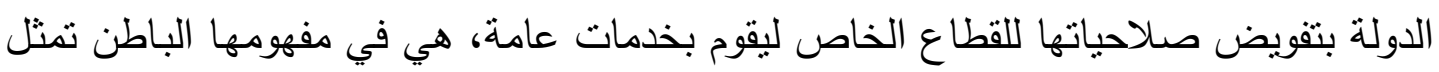

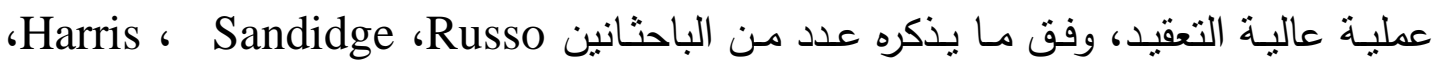
فليس للخصخصة مفهوم عالمي موحد يتفق عليه الجميع". Shapiro

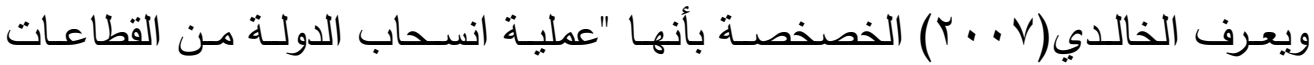

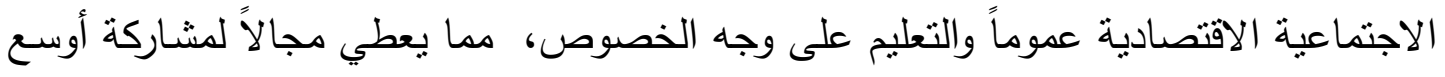

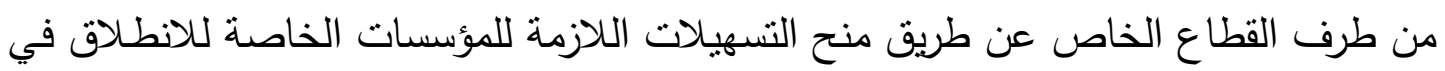

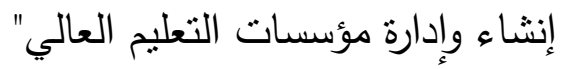

ويقصد العتيبي(1) ـ أهـ) بالخصخصة في التعليم بأنها "عبارة عن فرصة تعاون بين

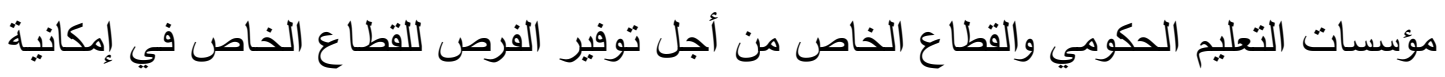
التوسع في إقامة المدارس والجامعات ومراكز البحث العلمي والتنريب وتملكها للغايات الربحية". 


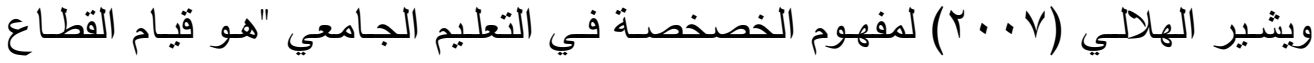

الخاص بتمويل وإنشاء وإدارة مؤسسات أو خدمات جامعية لتحقيق مجموعة من الأهداف يتم

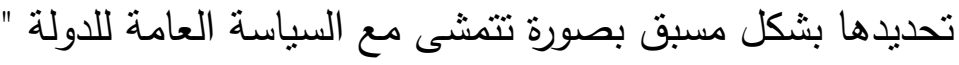

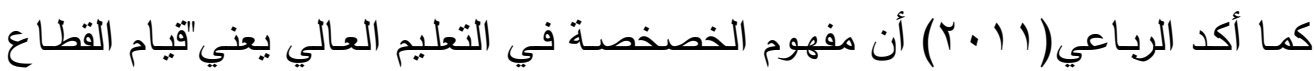

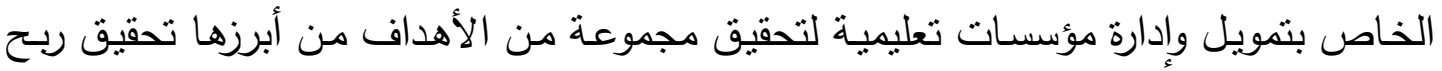

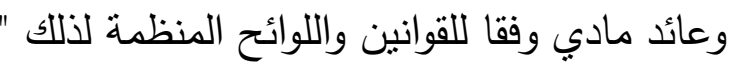

في ضوء المفاهيم السابقة التي تم عرضها لمفهوم خصخصة التعليم العالي فقد نوصلت

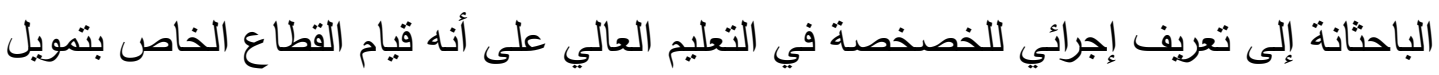

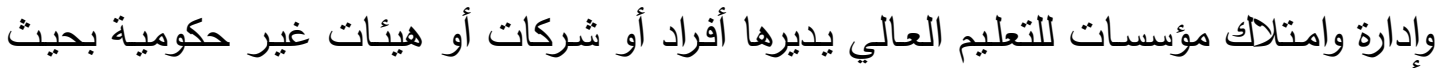
تتشمل جميع أنماط المؤسسات وتخضع لوزارة التعليم العالي في تقييم نوع الخدمة وكيفية أدائها ولا يكون هدفها الأساسي التربح، وذلك من أجل إحداث نقلات نوعية في أداء هذه المؤسسات.

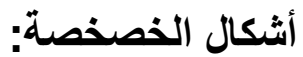

قسم عشيبة (1 + . rم) أنمـاط خصخصـة التعليم العالي في بعض الدول على ثلاثة أنماط كالتالي:

ا ـ الخصخصــة الكاملـة: تعطي الحكومـة فيها الصـلاحيات للقطـاع الخـاص بإنثـاء وإدارة

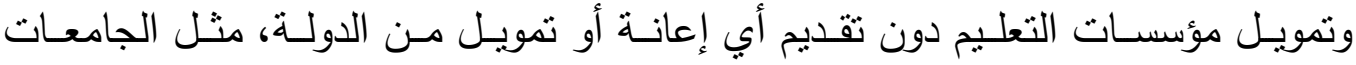

$$
\text { والكليات الغير معانة في ماليزيا. }
$$

r. الخصخصة المعتلةة: نسمح الحكومات للجهات الخاصة بإنشاء مؤسسات التعليم مع وجود

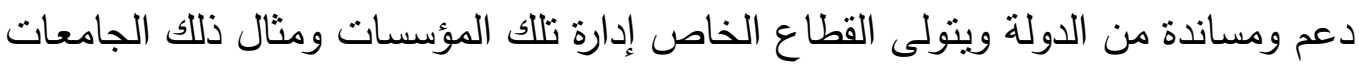

$$
\text { والكليات المعانة في اليابان. }
$$

r. الخصخصة البسيطة: تتولى الدولة فيها مسئولية إنشاء وإدارة وتمويل مؤسسات التعليم ولكنها في الوقت نفسه تستعين بمصادر التمويل الخاصة الأهلية منل الجامعات في الهند.

وفقًا للتقسيم السابق نجد أن المملكة العربية السعودية تقع ضمن الخصخصة المعتدلة

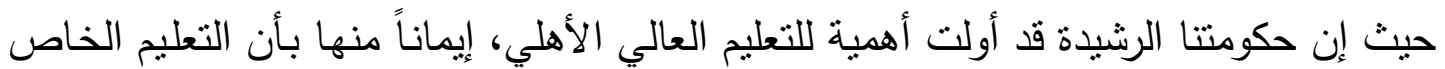

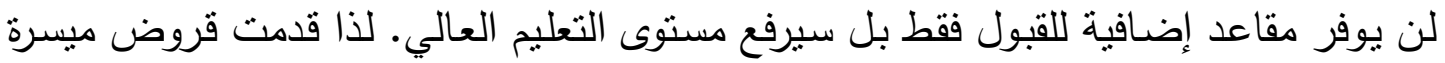

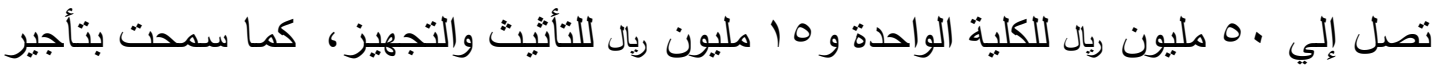

\section{TYO}


الأراضـي الحكوميـة بأسـعار رمزيـة للمستتمرين في التعليم العـالي الخـاص، وهي بـللك تتيح للقطاع الخاص المشاركة الفاعلة للنهوض بالتعليم العالي ولا يتطلب ذلك سوء شرطين: تقديم

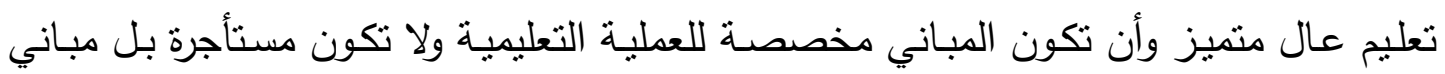

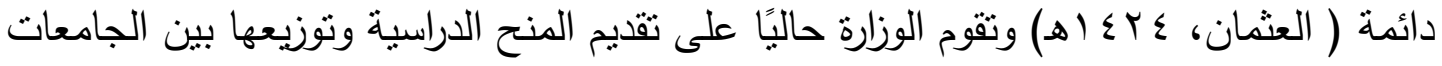

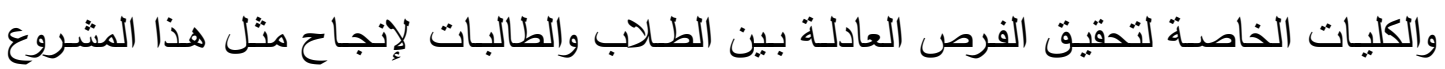

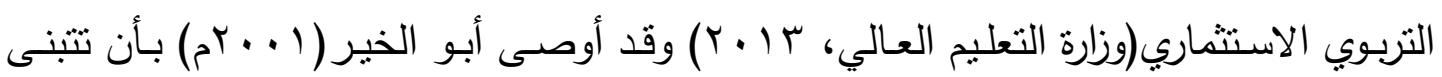

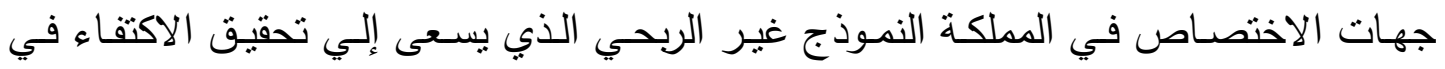

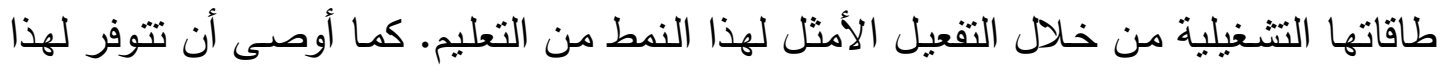

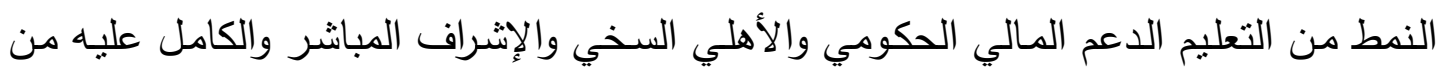

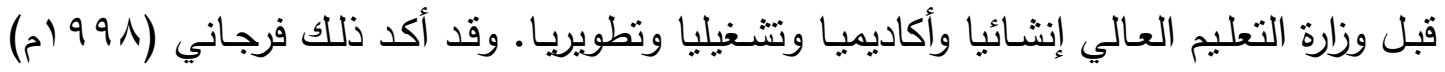

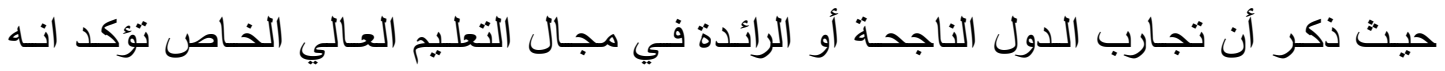

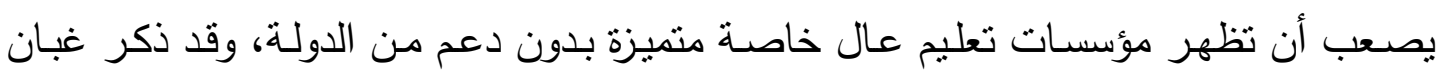

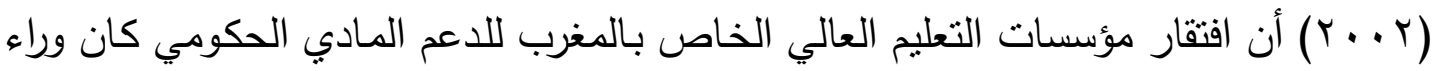

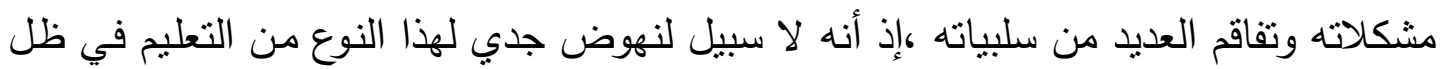

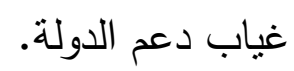

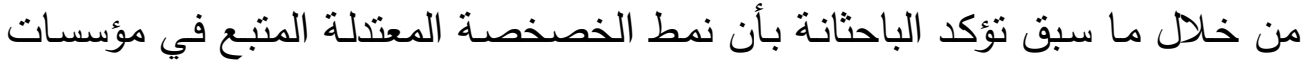

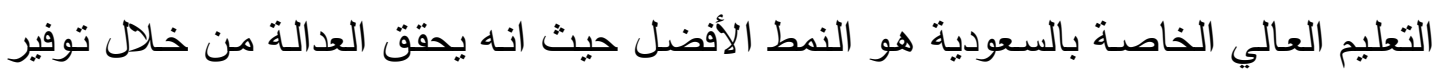

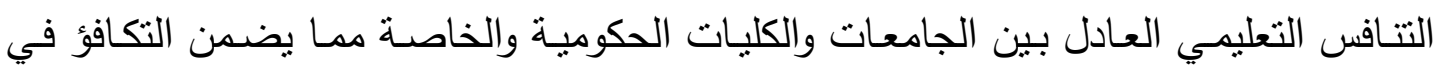

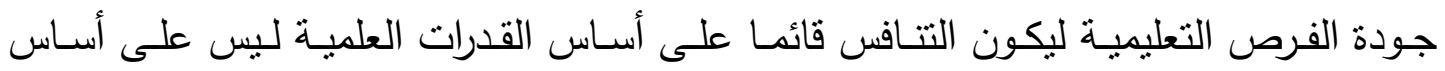

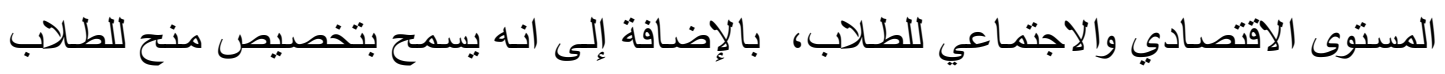

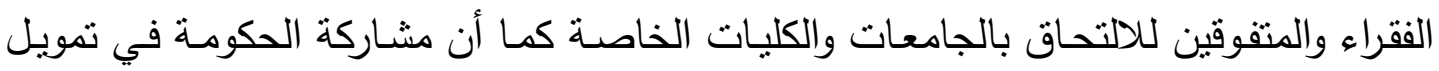

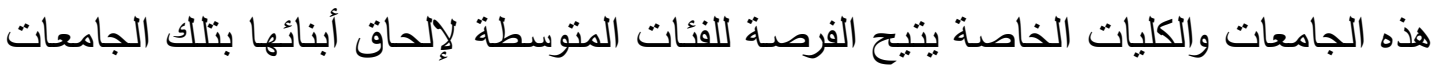

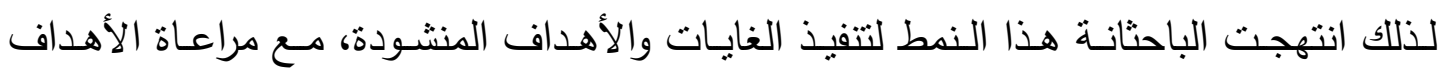
الرئيسية المرغوب تطبيقها في عملية التخصيص وتحقيقها.

\section{مبررات إنشاء مؤسسات التعليه العالي الخاصة:

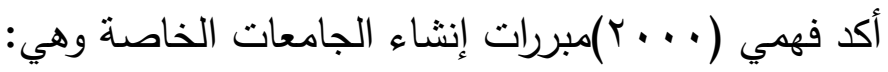


أ.مبررات تاريخية: التعليم العالي الخاص في نشأته كان في الحقيقة تعليمًا خاصا تتولى أمر

$$
\text { تقديمه مؤسسات أهلية }
$$

ب. مبررات اقتصادية: أن التطورات الاقتصادية الحديثة وخاصة بعد انهيار الاتحاد السوفيتي

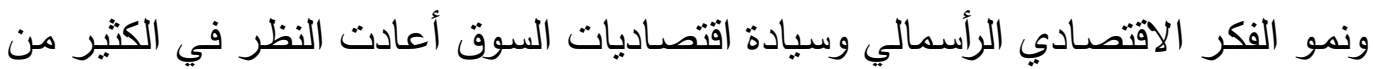

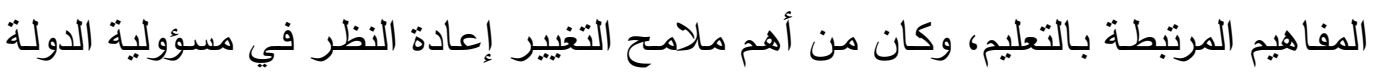

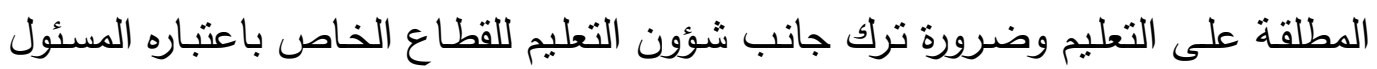

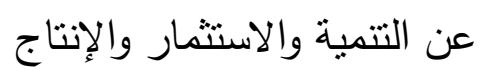

ج. مبررات اجتماعية: ومنها زيادة الطلب على التعليم الجامعي بسبب النمو السكاني، والتزام

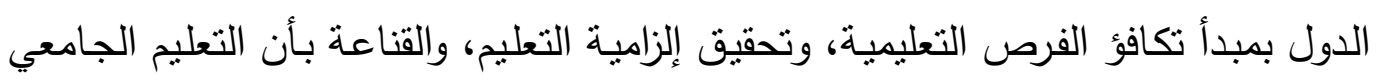

$$
\text { هو العنصر الأول في عملية الحراك الاجتماعي. }
$$

د. مبررات تعليمية: منها التكدس الكبير للطلبة في الجامعات الحكومية مما كان لله الأثر في

$$
\text { إضعاف الكفاية التعليمية المقدمة فيها. }
$$

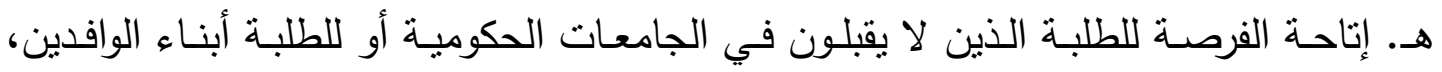

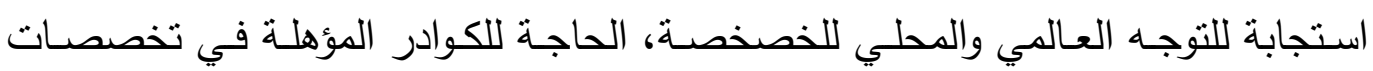
معينة غير متوفرة أو غير كافية في مؤسسات التعليم العالي الحكومية.

\section{إيجابيات مؤسسات التعليه العالي الخاصة :}

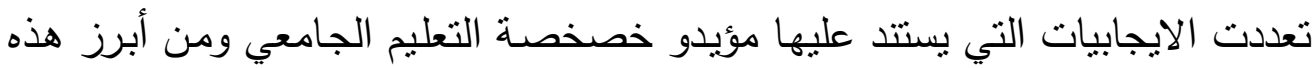

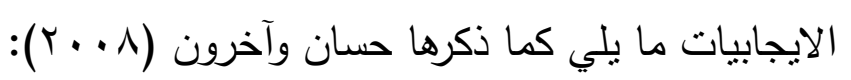

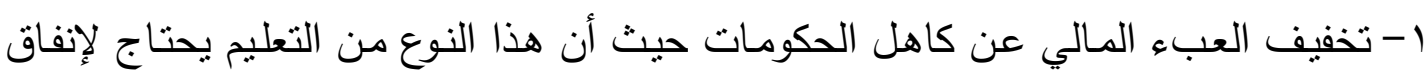

$$
\text { متزايد بالنظر إلى تنامي عدد السكان الهنان }
$$

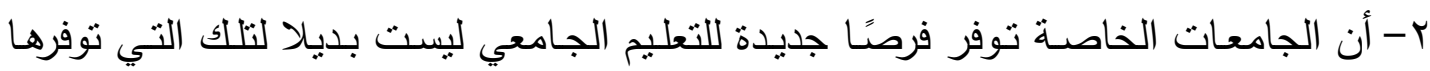

$$
\text { الجامعات الحكومية وإنما رديفًا لها. }
$$

r- استيعاب جميع الراغبين في التعليم الجامعي حيث الجيات أن نسبة التعليم الجامعي في الوطن العربي أقل بكثير من غالبية الدول الأجنبية. ع - إن الجامعات الخاصة بحكم ما تتمتع بـه من مرونة واستقلالية قد تكون أقدر على التكيف

$$
\text { مع المتغيرات الحديثة. }
$$

0- إنشاء الجامعات الخاصة يحقق التتافس باستحداث تخصصات جديدة يحتاجها المتمع. 
7- توفير فرص عمل لكثير من الأفراد مما يقلل نسبة البطالة في المجتمع.

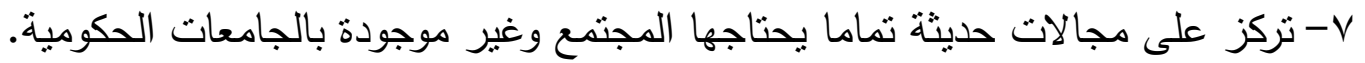

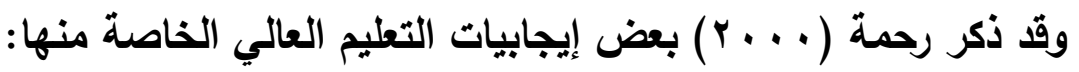

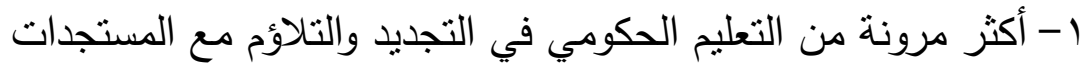

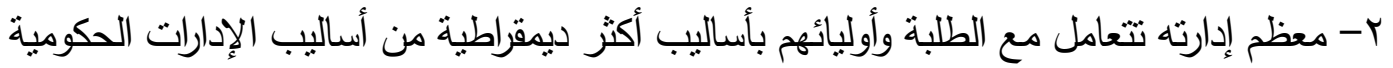

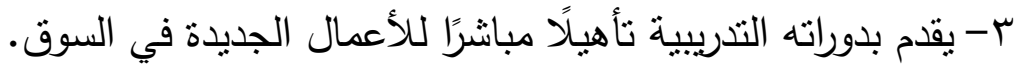

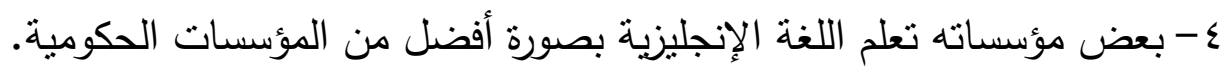
ه- يوجد أجواء منافسة بين مؤسسات التعليم العالي. צ- يزيد فرص التعليم ويحقق رغبات الكثيرين في الالتحاق بفرص التعليم العالي.

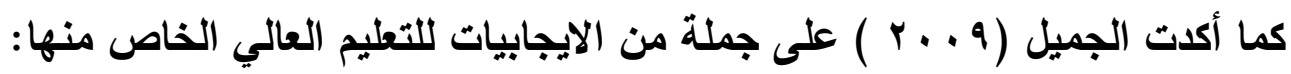

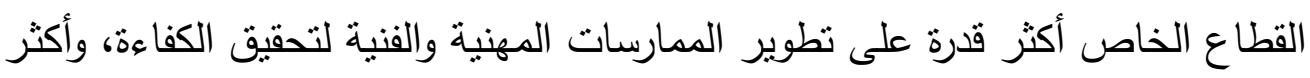

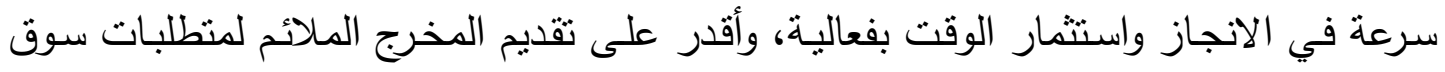
العمل، وأكثر قدرة على احتضان التدريب كما أنه يحقق اللامركزية في التخطيط وتنفيذ الأعمال بالإضافة إلى أنه أكثر قدرة على استتمار الموارد المادية المتاحة لتحقيق الربحية.

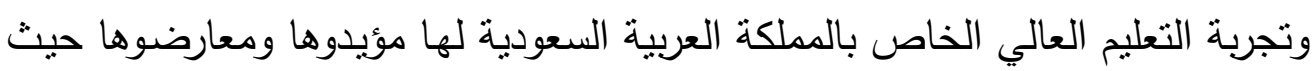

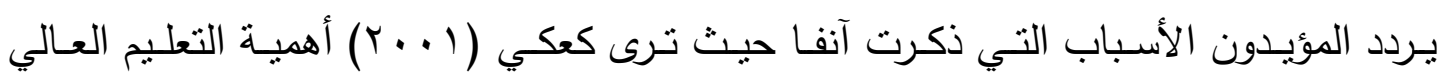

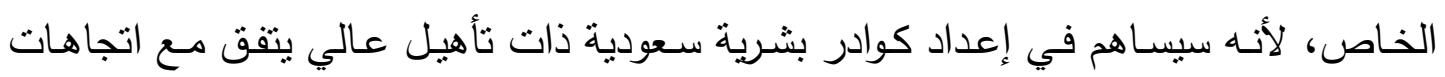

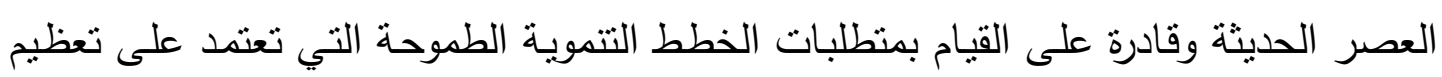

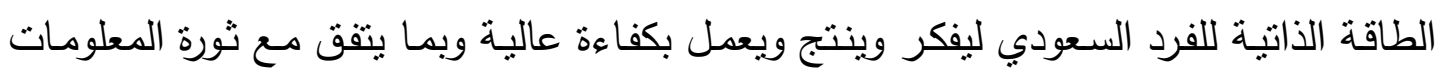
والإلكترونيات الحديثة.

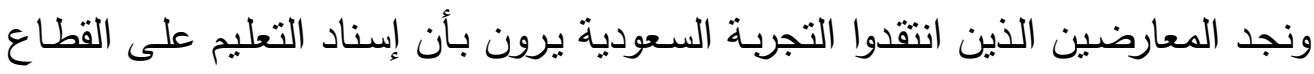

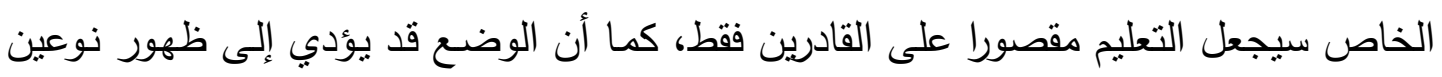

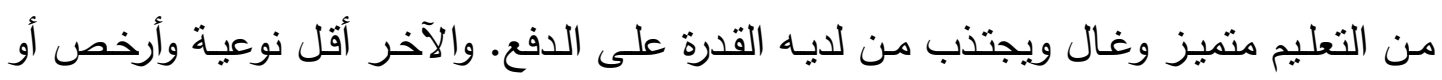

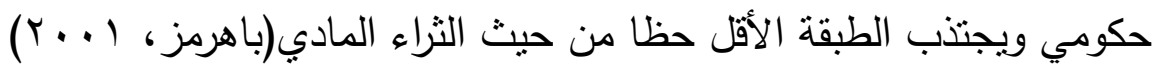

\section{السلبيات التي تواجه خصخصة التعليه العالي:}

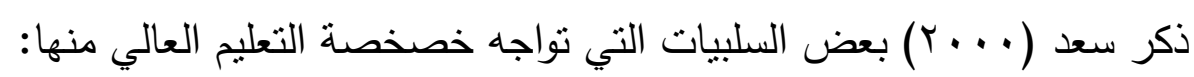


لم يستطع التعليم العالي الخاص كسب ثقة المواطن بحيث يصبح منافسًا للتعليم العالي الحكومي، هذه الثقة التي تؤدي إلى الارتقاء به كما هو متوقع منه، والتوسع في فتح مؤسسات التعليم العـالي الخـاص دون التأكد من مدى توفر الثـروط الضـرورية اللازمـة لتقديم التعليم

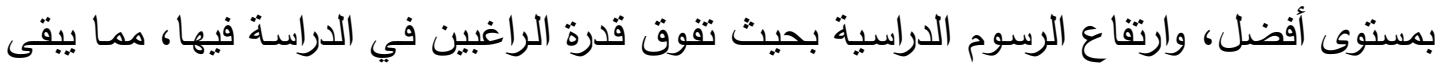
الضـطط على التعليم الجامعي الحكومي، إلى جانب عدم تعود المواطن على شـراء الخدمة التعليمية واعتقاده بأن ذلك من مسؤولية الدولة وحدها، والتركيز على فتح التخصصات النظرية نظرًا لقلة التكاليف التي تتطلابها، مقارنة بالتخصصات العلمية. وهنـاك مجموعـة مـن السلبيات لخصخصـة التعليم العـالي التـي تتطـرق لها (رحمـة،

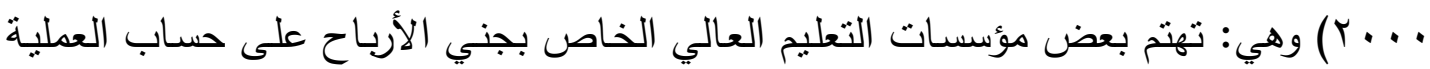
التعليمية التربوية، ومخالفة بعض مؤسسات التعليم العالي الخاص أهداف الدولة وسياستها في

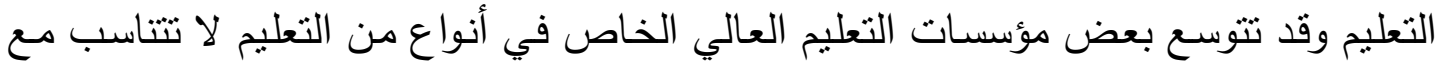
حاجـات المجتمـع، ويغـرس التعلـيم العـالي الخـاص بعض الفـروق الطبقيـة الاجتماعيـة بـين المواطنين، قد يؤدي التعليم العالي الخاص إلى هبوط مستوى التعليم العالي الحكومي.

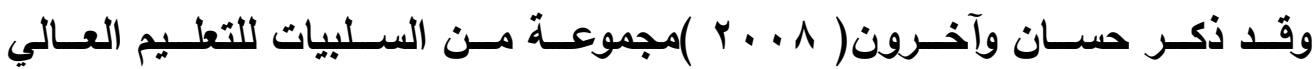

1- أن الجامعات الخاصـة نؤدي إلى ظهور طبقيـة التعليم العالي مهـا يسهم في تعميق التفاوتات الاجتماعية والاقتصادية

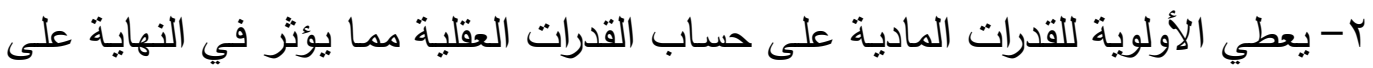

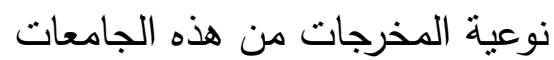
r- قد نتزع الجامعات الخاصة التعليم العالي من إطاره التقافي والوطني إلى إحدى حلقات التبعية والتغريب. ع - قد تهدد مبدأ تكافؤ الفرص التعليمية وتقوض ديمقراطية التعليم الجامعي حيث أنها تيح فرصا للقادرين ماديا

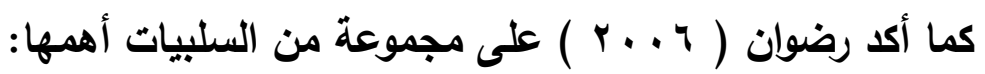

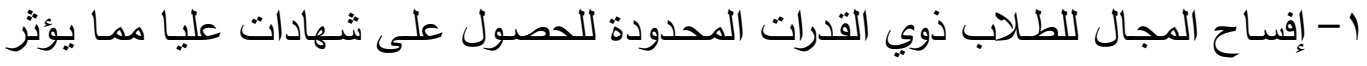
على قيادة البلد مستقبلا. r- أن الجامعات الخاصة مشروع استثماري وليس هدفها النطوير . 
r- أن الجامعات الخاصة سترتبط بنظريات غربية في التعليم مما يسبب الإقساد في المجتمع.

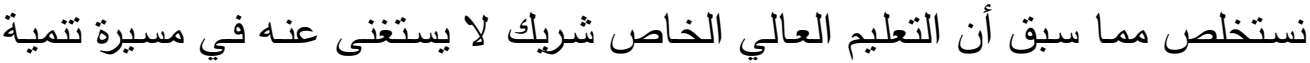

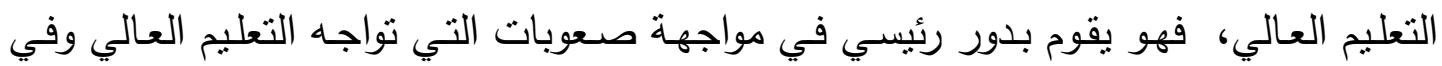

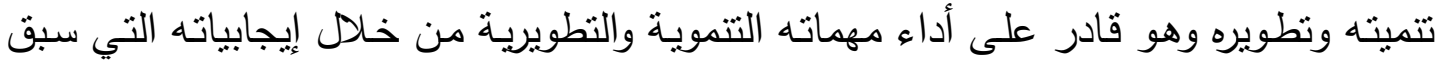

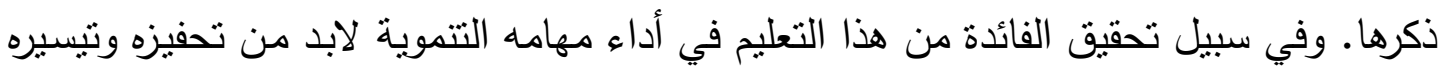

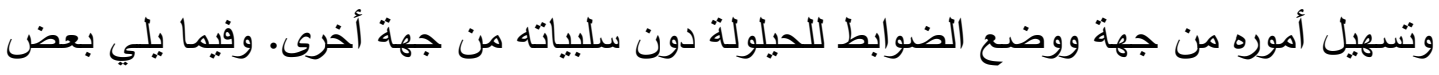

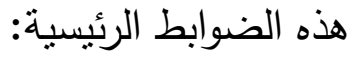

\section{ضوابط نجاح التعليم العالي الخاص:}

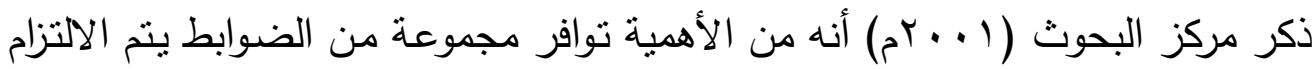

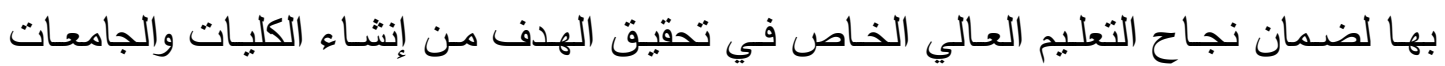

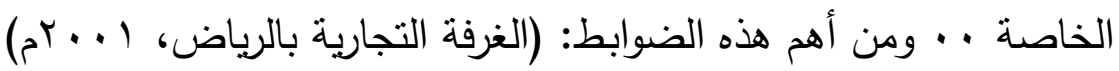

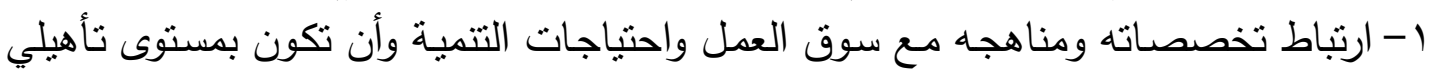

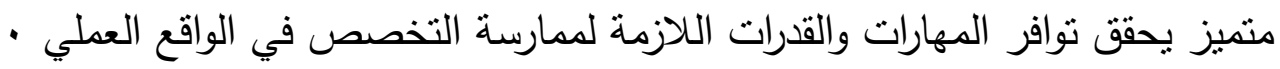

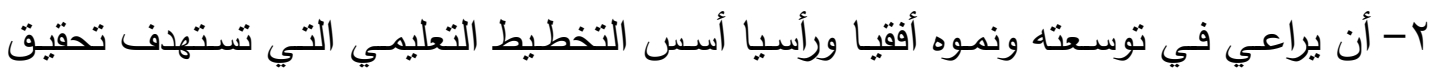

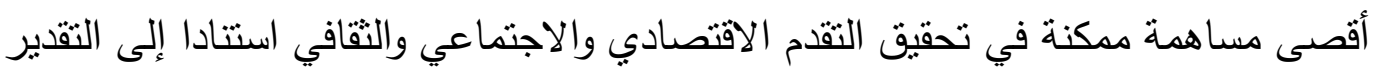

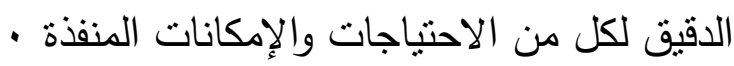

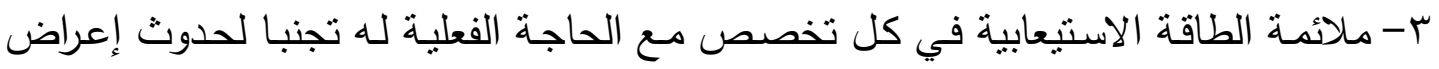

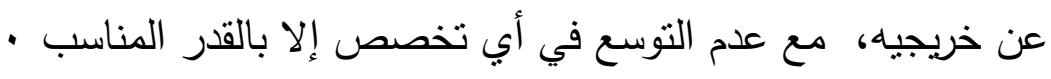

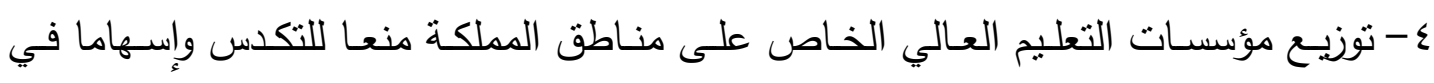
تحقيق التتمية الإقليمية المنوازنة .

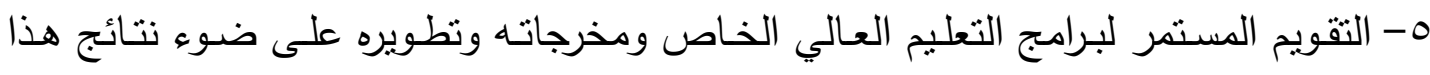

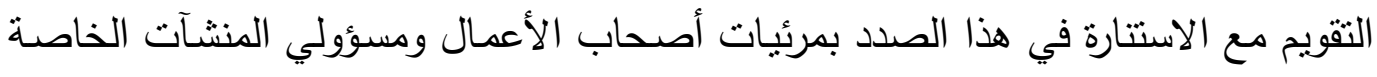

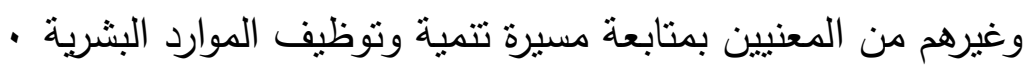

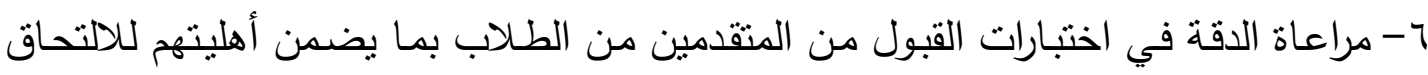

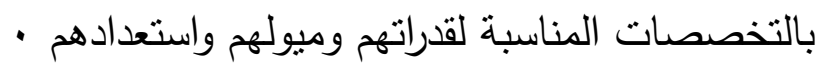
V- إخضاع التعليم الخاص لرقابة فعالة وتتسيق متكامل في إطار سياسة التعليم العالي للدولة

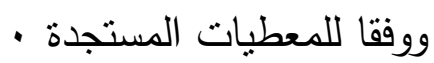
^- مواكبة النطورات والمتغيرات خاصة في مجالات الاكتشافات التي تنت في مجالات العلوم والثقنية واستخداماتها في التعليم · مواتهرات 
9- ترتبط أن يعطي جانبـا مـن الاهتمـام للبحوث والدراسـات التطبيقيـة وفقا لواقـع المنشـآت واحتباجات

• 1- الكليات الأهلية بالمتمع وتوثق علاقاتها به بكافة السبل وإتباع أساليب تحقق ذلك مثل:

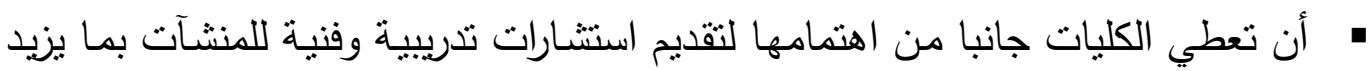

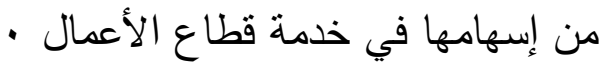

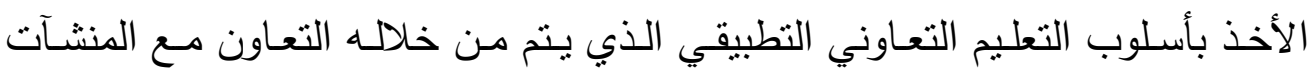

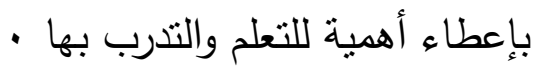
هإنشراك المتخصصين وذوي الخبرة في المنشآت في أنشطة الكليات مثل إلقاء بعض

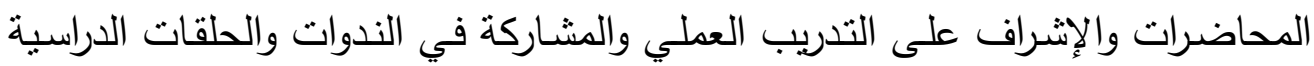

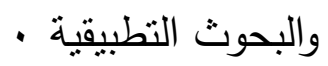

1 ا .دراسة تجارب الدول الأخرى في مجال التعليم الأهلي والاستفادة بما حققته من نتائج

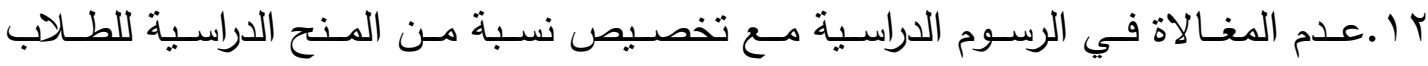

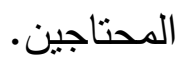

\section{المبحث الثاني : تجارب دول أخرى في خصخصة التعليم العالي.}

سنعرض بعض تجارب الدول في خصخصة التعليم العالي، وقد تم اختيار هذه الدول لاختلاف أنماط الخصخصة فيها، ولاختلاف بيئتها من عربية وخليجية وأجنبية، ولاختلاف عمر التالية

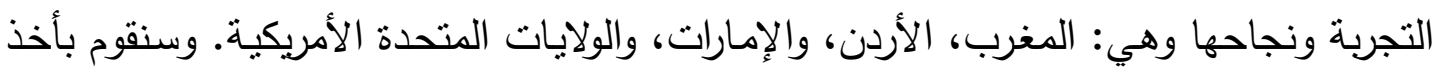
كل دولة على حده وعرض نبذة حول نمط تطبيق الخصخصة المتبع فيها ومن ثم توضيح كلاً

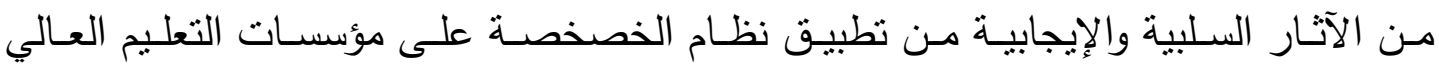

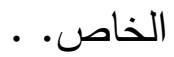

أولاً: تجربة التعليم العالي الخاص في المملكة المغربية(غبان، ب . . ب م )

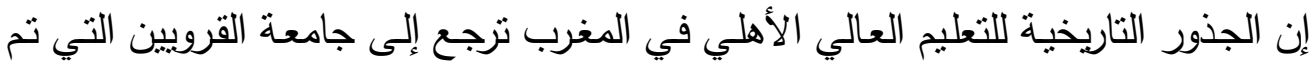

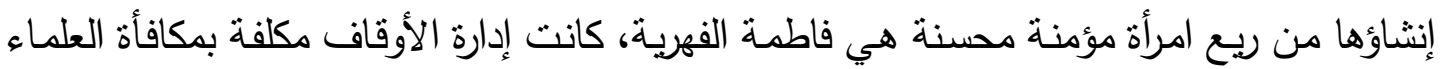

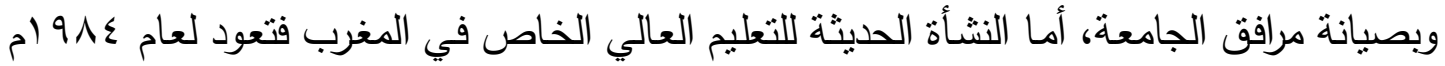

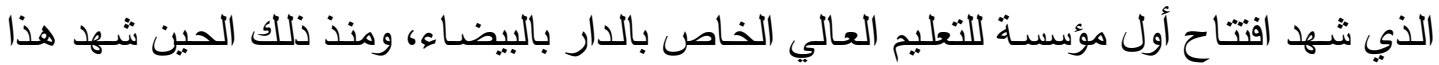

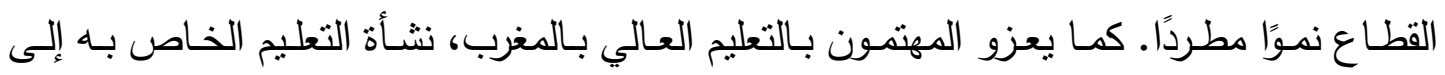


التحولات الاقتصادية التي شهدها المغرب وفي ضوء ذللك الوضع اكتسب التوجه نحو (الخصخصة)

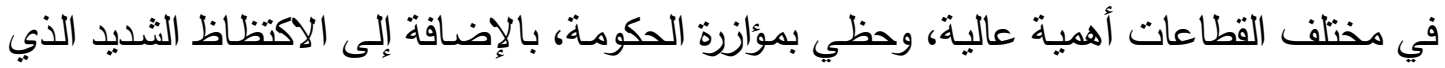

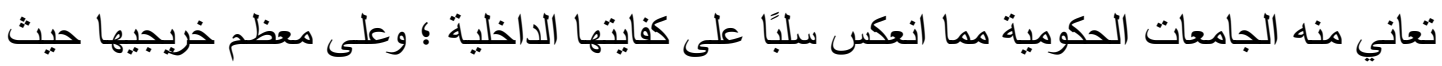

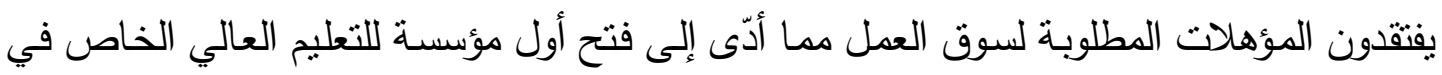
ميادين محدودة كانت مطلوبة في السوق. نمط التعليم الجامعي الخاص في المغرب:

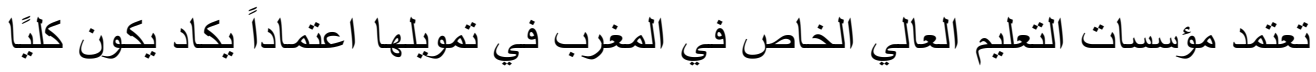

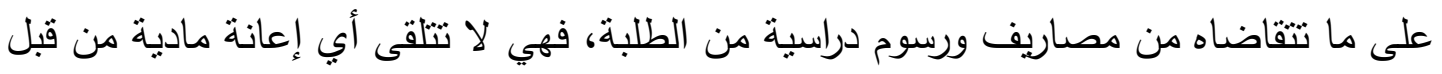
الحكومة، أو تبرعات أو هبات من القطاع الخاص فهي تمثل على هذا النحو شكلًا من أنثكال

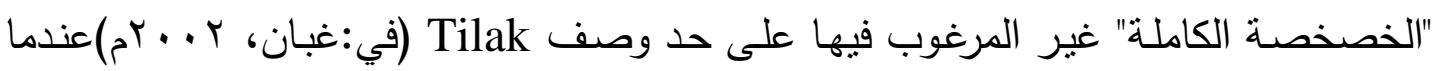
حاول أن يصنف مؤسسات التعليم العالي الخاص.

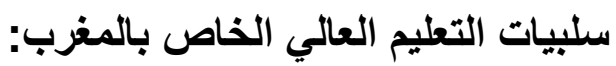

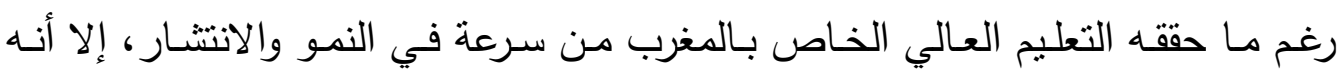
يعاني من مشكلات ونواحي قصور عدة، أهمها ما يلي:

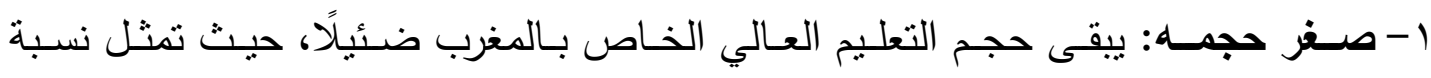

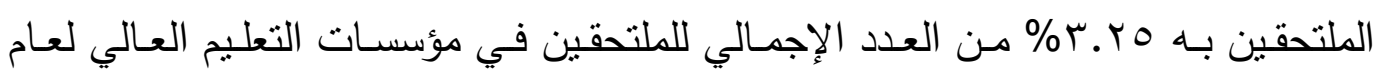

$$
\text { . . . / / } 1999
$$

r-وصمه بمـلاذ للراسبين: يصفه البعض بالقول: إنه "لا يشكل، في جزء كبير منه، سوى

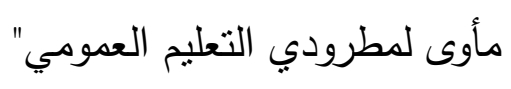

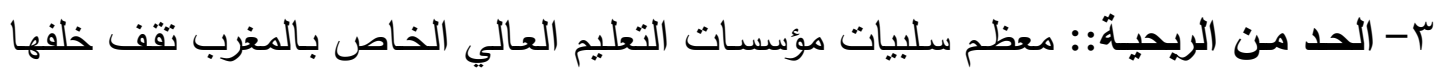

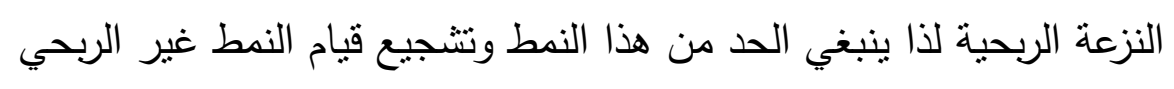

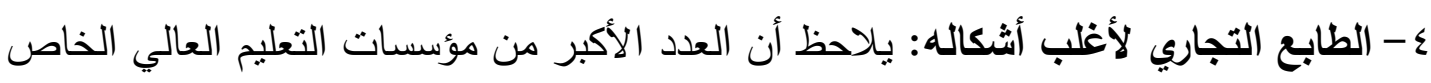

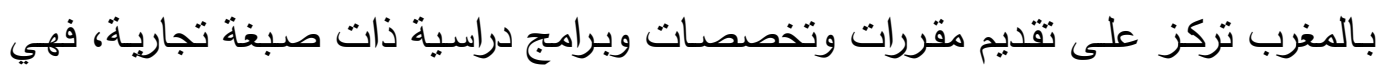

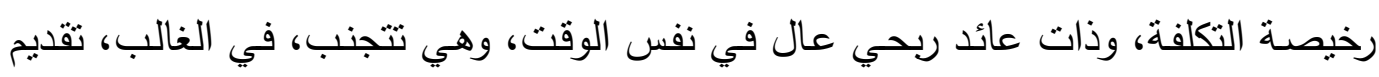
التخصصات التي تتطلب استثمارات تجهيزية وتقنية عالية التكلفة ماديًا.

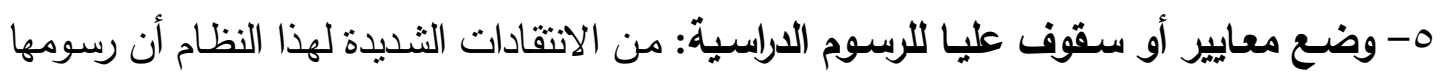

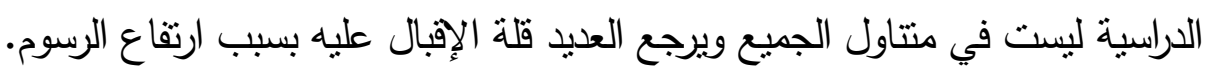


1- ضرورة دعم الدولة للتعليم العالي الخاص: أن افتقار التعليم العالي الخاص بالمغرب للدعم

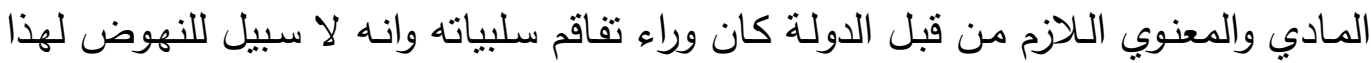
الثكل من التعليم في غياب هذا الدعم

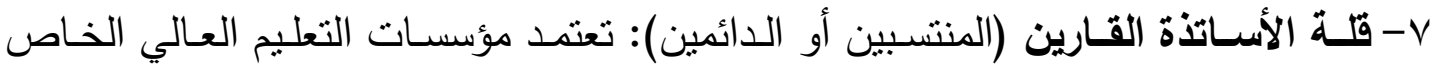

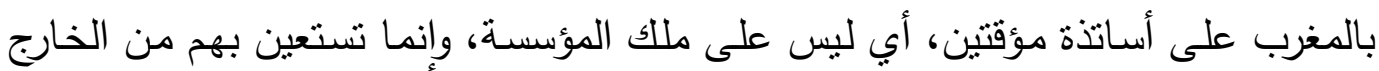

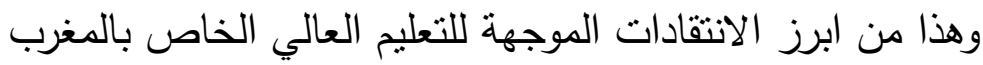

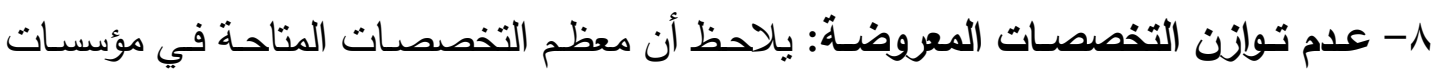
التعليم العالي الخاص بالمغرب مركزة في ميادين التجارة وتدبير (إدارة) الدقاولات والدحاسبة والتقنيات البنكية والتأمين ونحوها، وفي المقابل بلاحظ غياب معظم التخصصات الصناعية والطبية، التي تحتاج إلى تجهيزات ومختبرات ومعدات ذات تكلفة مادية عالية

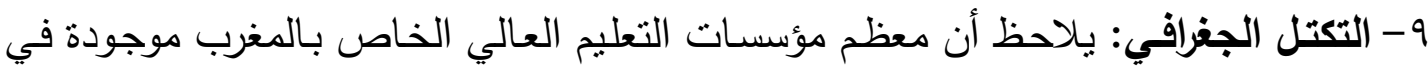
عدد محدود من المدن، وأنها تتركز بشكل واضـح في مدينـة الدار اليضضـاء (العاصـمة (التجارية للمغرب)

•

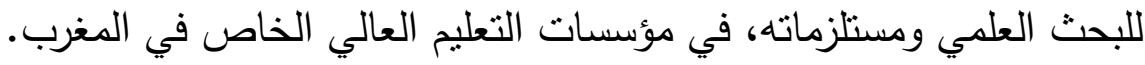
إيجابيات التعليم العالي الخاص بالمغرب:

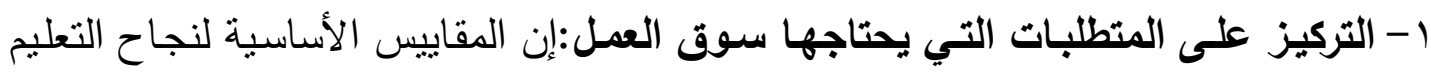

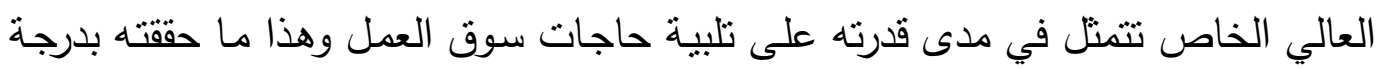
مقبولة التجربة المغربية. r- التركيز على التدريب والتعليم التعاوني: من الأسباب المفسرة لاستقطاب القطاع الخاص التصاص

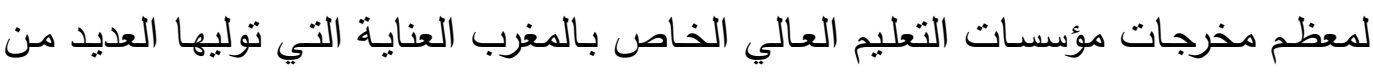

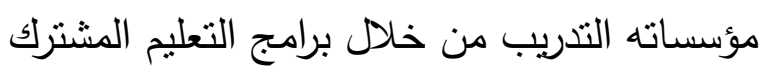

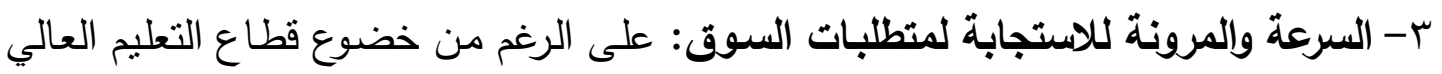

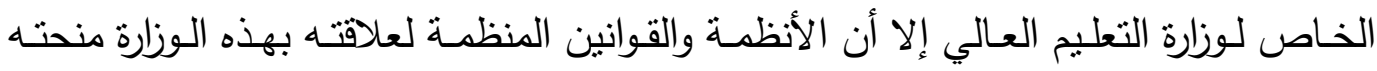

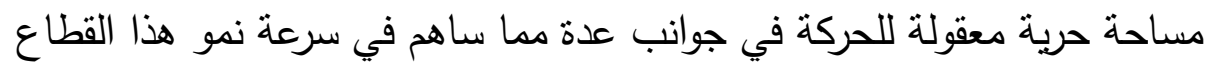

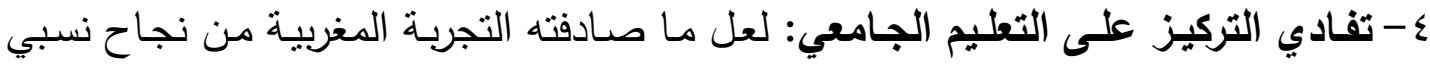

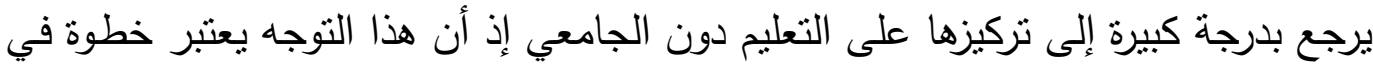
الاتجاه الصحيح لان مخرجات هذا المستوى مطلوبة بشدة في سوق الإنيم دون الإنتاج 
رغم ما حققه التعليم العالي الخاص بالمغرب من سرعة في النمو والانتتار، إلا أنه يعاني

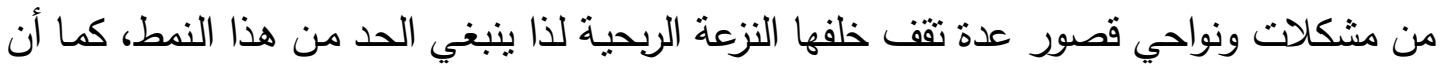

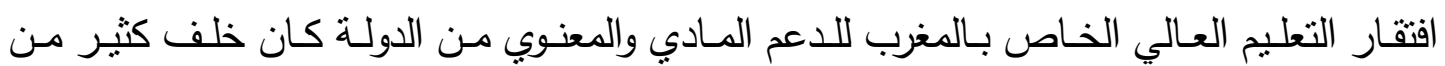

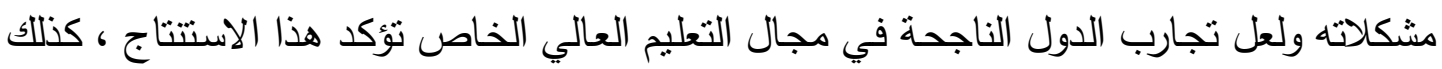

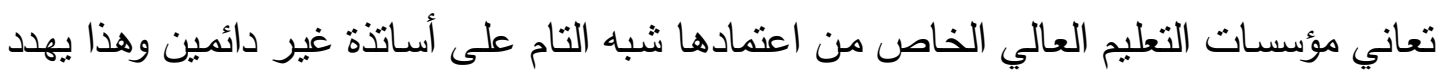

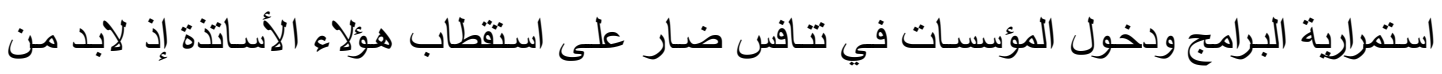

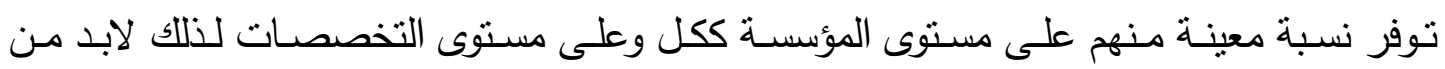

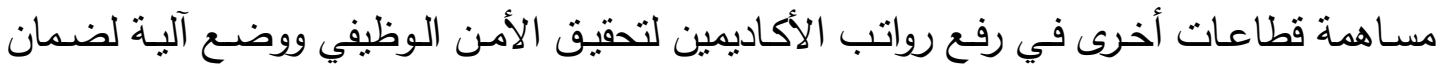

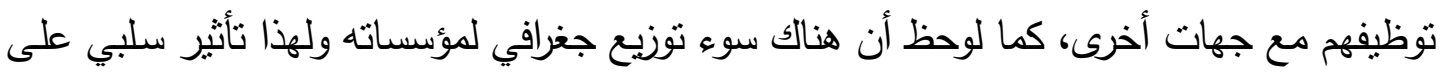

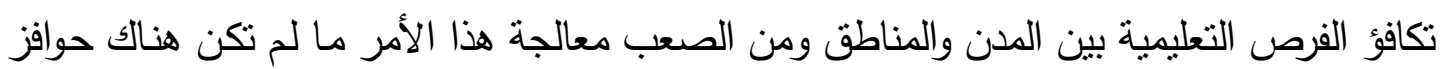

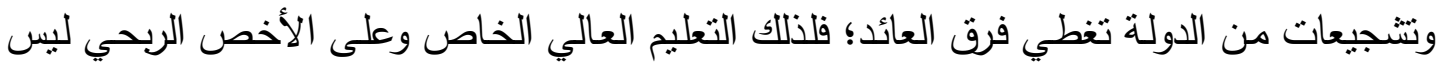

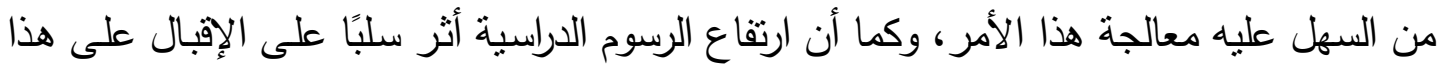

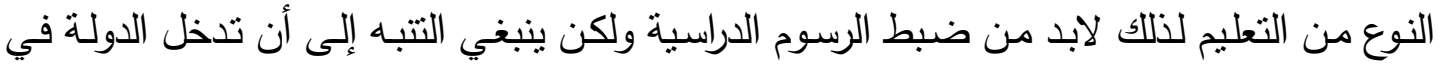

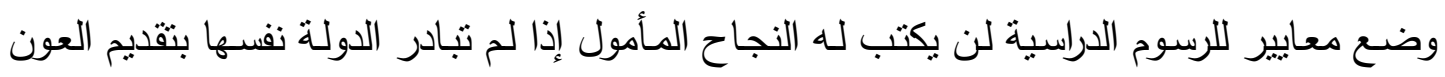

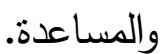

وعلى العهـوم يمكن القول إن الكفايـة الداخليـة والخارجيـة لمؤسسـات التعليم العـالي

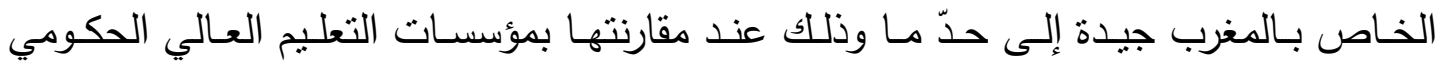

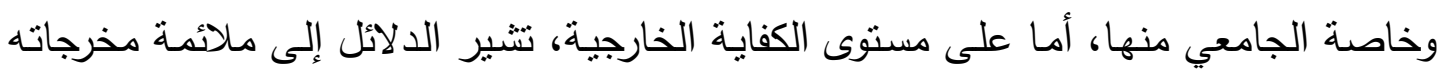

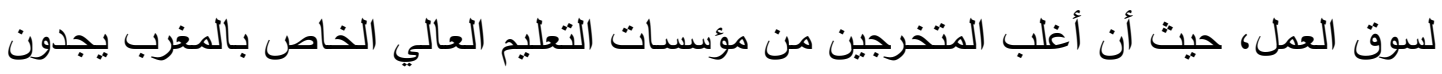

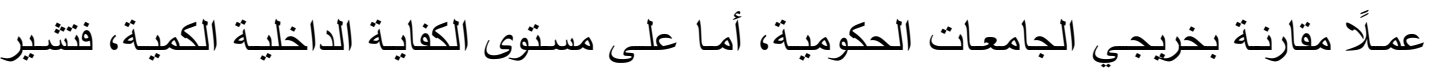

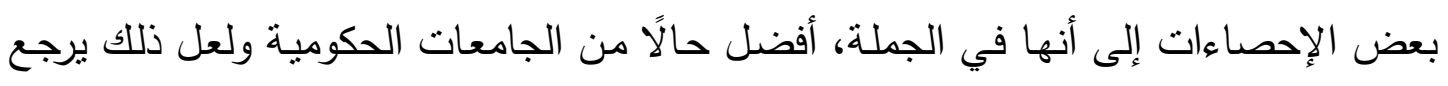

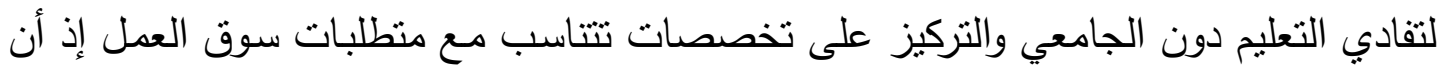

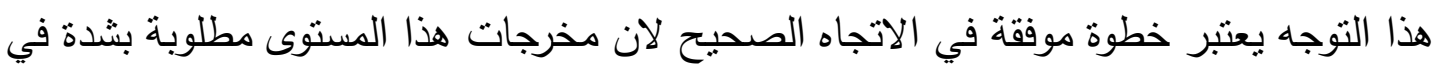
عالم الإنتاج.

ثانيًا: تجربة التعليم العالي الخاص في المملكة الأردنية الهاشمية:

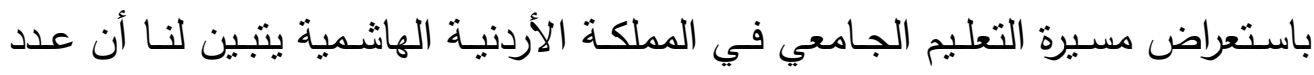

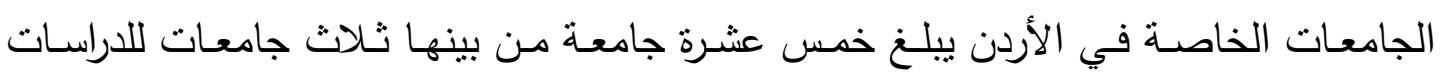

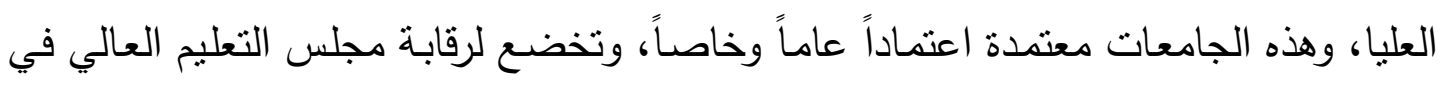


الأردن (المحفظة الوطنية للأوراق المالية في الأردن، ـ ـ بام)منها الجامعة الأردنية والبلقاء التطبيقية إضافة إلى عدد كبير من الكليات المتوسطة التي كانت في الأصل معاهداً للمعلمين.

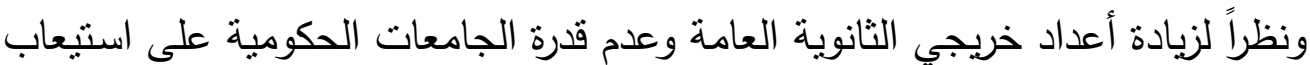

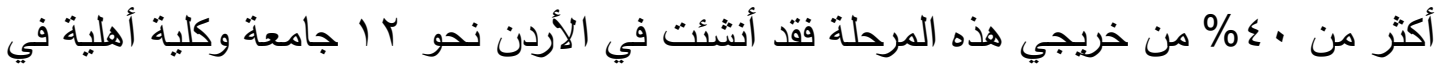
الفترة من 1919 إلى ـ99 19 السد هذا النقص الاستيعابي للجامعات الحكومية. وتقوم الجامعات

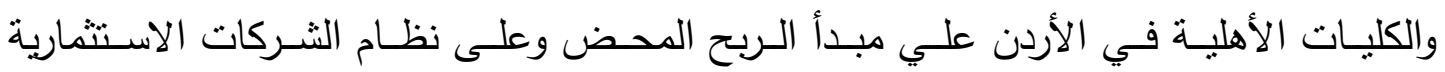

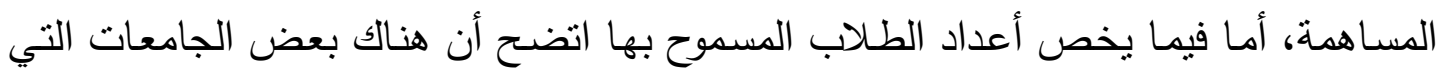

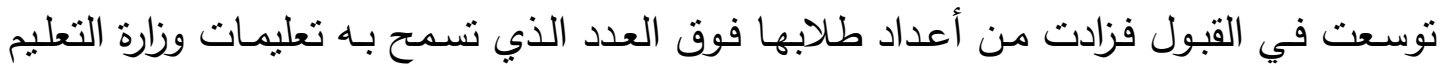
العالي ومعايير الاعتماد العام والخاص المعتمدة فيها وذللك لتعويض الفرق الناتج عن سياستها لفاعال

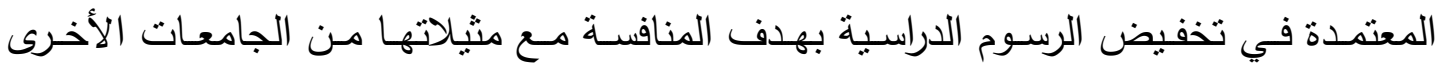

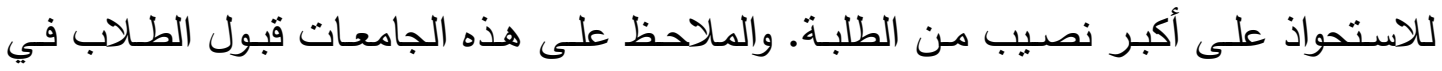
التخصصـات النظريـة والعلميـة بتقديرات أقل من المعدلات والتقديرات التي يتطلبها الالتحاق بالجامعات الحكومية، الأمر الذي أدى إلي إخفاق كثير من الطلاب في مسارهم التعليمي في لئي

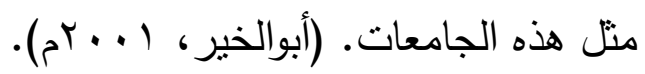
نمط التعليم الجامعي الخاص السائد في الأردن:

يمكن القول بأن نمط الخصخصة السائد في الأردن هو نمط الخصخصة الأنسان الكاملة ؛حيث

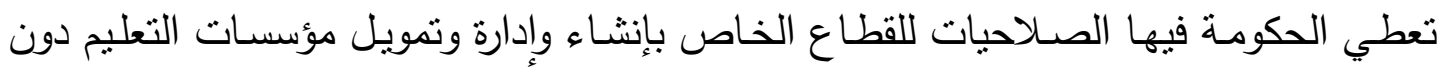

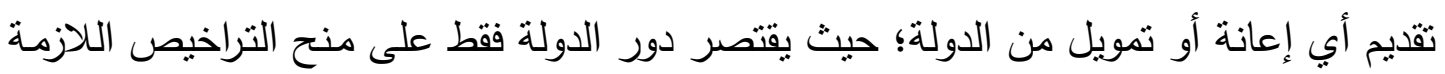

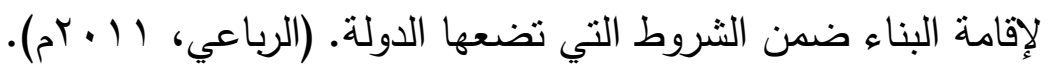
ومن الملاحظ أيضـاً على هذه الجامعات تماثل التخصصـات المقدمة فيها وبخاصـة

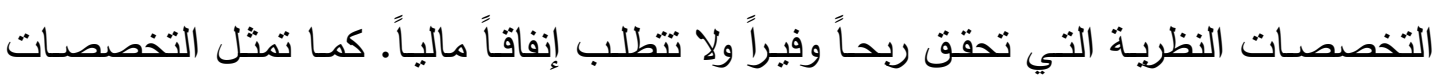

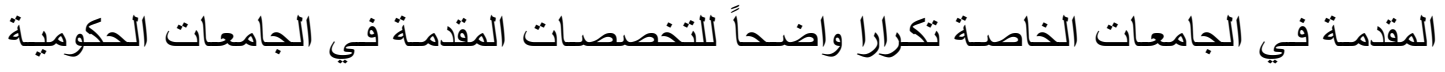
باستثاء بعض التخصصات المحددة في مجال إدارة المستتفيات، والتسويق والتحاليل الطبية،

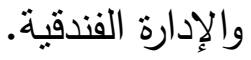

كمـا أن بعض الجامعات الخاصـة الأردنيـة تعد محدودة بصورة عامـة في إمكاناتها

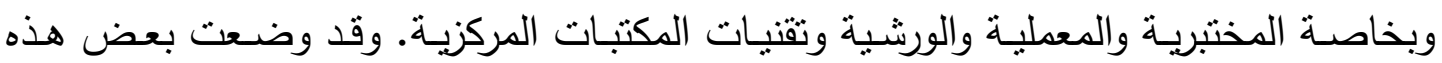

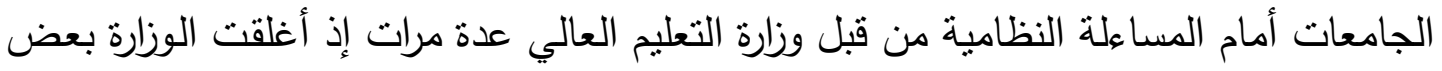


التخصصات في إحدى الجامعات الأردنية، وهددت بإغلاق بعض التخصصات في جامعات

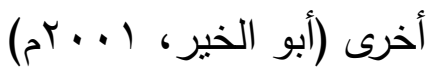

\section{إيجابيات تجربة التعليم العالي الخاص للمجتمع والاقتصاد الأردني وللتعليم العالي:}

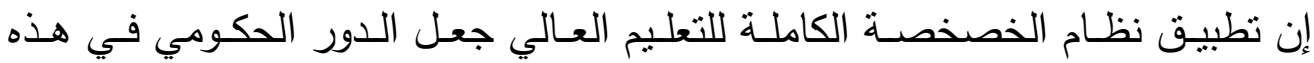

المؤسسات يقتصر على الدور الرقابي ويبعد المنشأة التعليمية عن التعقيدات والإجراءات المطولة

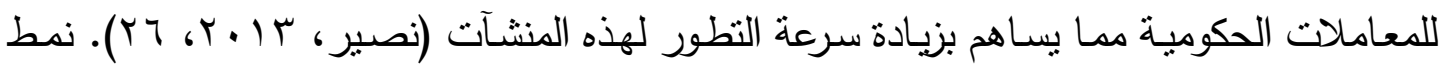

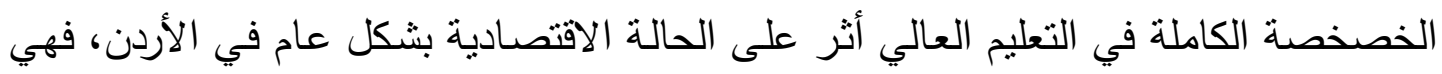

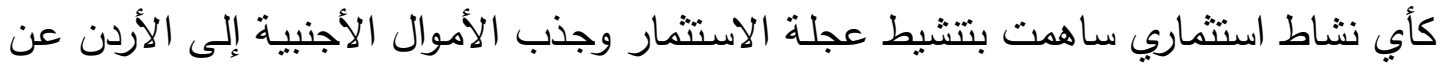

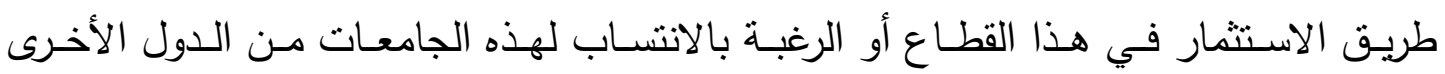

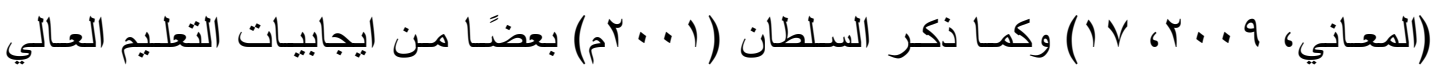

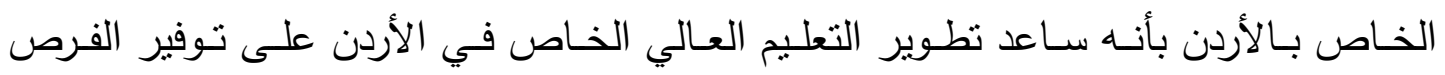

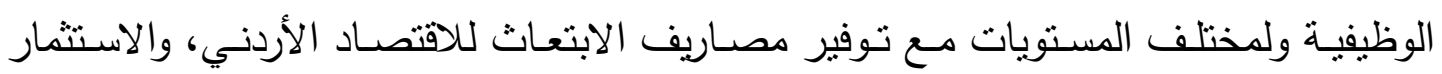

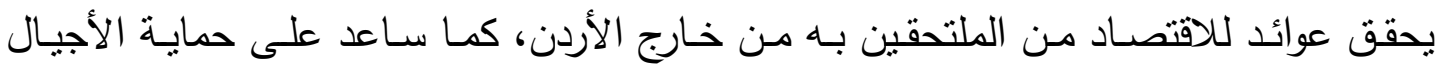

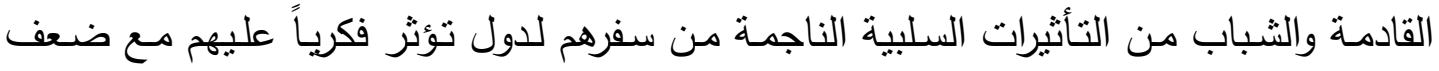

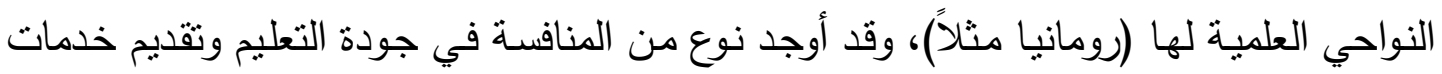
التعليم العـالي بين القطـاعين الحكومي والخـاص، ووفر التقنيـة الحديثة اللازمـة لدعم العمليـة التعليميـة وتطويرهـا لتتماثـى مـع التغيرات والمؤثرات الاقتصـادية العالميـة مثل العولمـة، الالتزام بالنسب المحددة للقبول في الجامعات الحكومية ولمختلف التخصصات والكليات

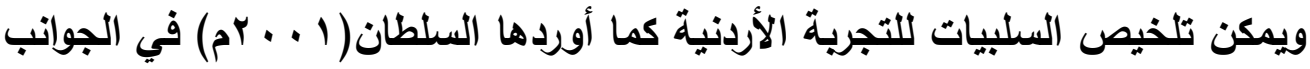

ككل مشاكل التعليم العالي في العالم العربي وفي المقابل يعتبر رافداً رئيسياً لدول العالم

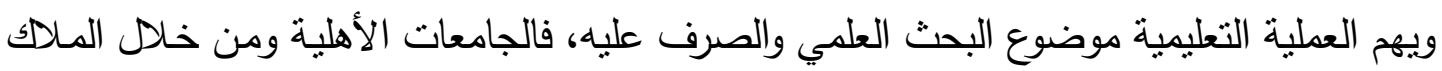
يهمها تخفيض الدصاريف واعتبار الصرف على البحث العلمي غير مجدية على المدى القصير،

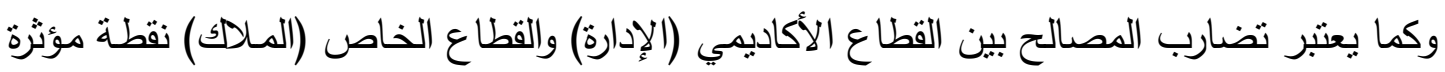

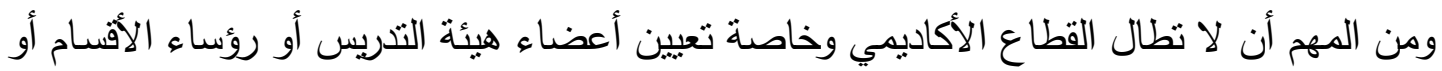

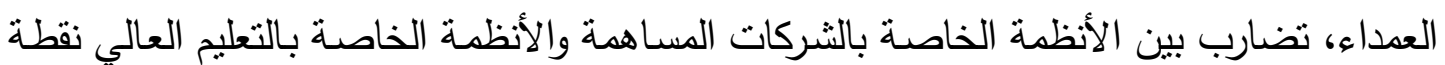

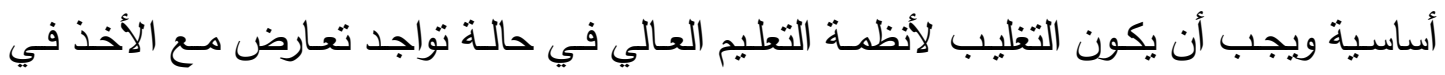
الاعتبار عدم ظلم الملاك، كما أن نفوذ الملاصك يجب أن يكون في حدود لا تؤثر سلباً على العطلية 
التعليميـة وجودتها والملاحظ أن هنالك نوع من الثـد ومـع نوعية مديري الجامعات تم الحد بصورة كبيرة من هذه السلبية، كما نلاحظ أنه يعاني التعليم العالي الأهلي في الأردن من عدم تقيد بعض الجامعات الأهلية بالأسقف التي تقررها وزارة التعليم العالي بالنسبة لأعضاء هيئة التدريس في ضوهي التهاء أعداد الطلاب المقيدين فيها فعلا. وقد دعا هذا الوضع الوزارة إيقاف بعض التخصصات فيها، وقد أكد البيلاوي ( . . . rم) أن بعض الجامعـات الخاصـة في الأردن قد لهثت وراء الـربح السـريع فانخفض المستوى التعليمي فيها إضـافة إلى أن التعليم الخاص لم يف بعهوده في تحقيق أهدافه الهـ وتقديم أنمـاط ونمـاذج جديدة مواكبـة لمتغيـرات العصـر الذي نعيشـه، بـل ظل تقليديًا وفي إطـار التخصصـات التقليدية، و ذكر المنيع(r r) أن من أهم المشكلات التي يواجهها المعلمون تدني الرواتب في كليات المجتمع، وأنه لا يؤخذ برأي المعلمين عند وضـع المنـاهج والخطط الدراسية ولا يتم تتمية قدراتهم التعليمية.

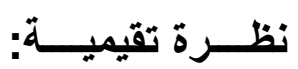

إن تجربـة التعليم العالي الخاص الأردني تجربة حديثه من ناحية وربحية تعتمد ابتداء على رؤوس الأموال الفردية ونظام الثركات الاستثمارية المحدودة والتضامنية من ناحية أخرى. وتطبق الثـركات التي أنشأت الجامعات والكليات الأهلية في الأردن قوانين العرض والطلب والربح والخسارة مستفيدة من القانون الاستثماري التجاري للشركات الأردنية الذي كان عاملا وراء إدارة أصحاب رؤوس الأموال لهذه الجامعات.

يحتـاج النــوذج الأردنـي في التعليم العـالي الخـاص إلـي دعـ إمكاناتـه بشـكل عـام

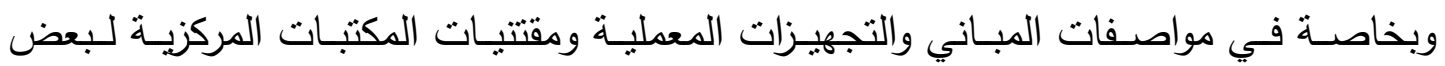
الجامعات الخاصـة. إضـافة إلي ذلك فهو يحتاج إلي دعم للكوادر التدريسية الوطنية إذ بعتمد هذا النموذج إلي حد ما على أيد غير وطنية من أعضاء الهيئة التدريسية والفنية الأمر الذي قد إند يزعزع حالة استقراره عند حدوث الأزمات السياسية أو المالية. كمـا يعاني التعليم العـالي الخاص هنـالك من قبول بعض الجامعات الخاصسة لأعداد طلابية تزبد عن حصصها المقررة من قبل وزارة التعليم العالي وذلك لتعظيم ربحها أو تعويض الفرق الناتج عن سياستها في تخفيض رسومها الدراسية بهدف المنافسة مع غيرها من الجامعات الأهليـة للاسـتحواذ على أكبـر نصـيب مـن الطـلاب الـذين لا تسـتطيع الجامعـات الحكوميـة استيعابهم أو ترفض قبولهم لتدني معدلاتهم في المرحلة ما قبل الجامعية.

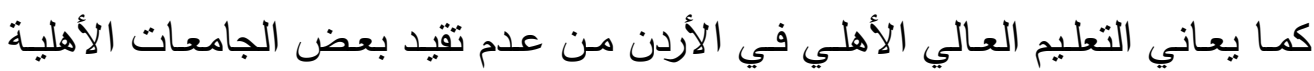

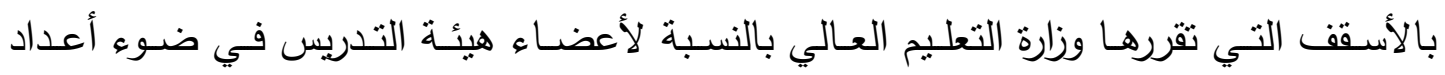


الطلاب المقيدين فيها فعلا. وقد دعا هذا الوضع الوزارة إلي توجيه الإنذارات إلي بعض هذه الجامعات وايقاف بعض التخصصات، ومن الملاحظ تكرر التخصصات المقدمة في الجامعات

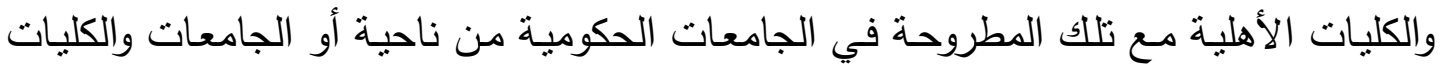

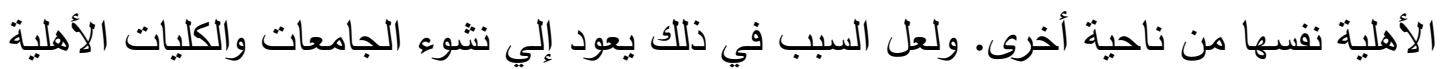

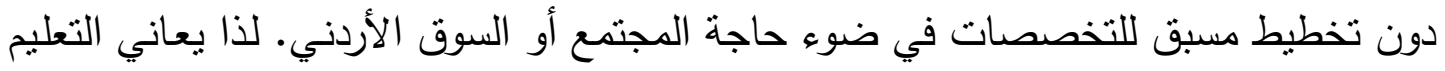

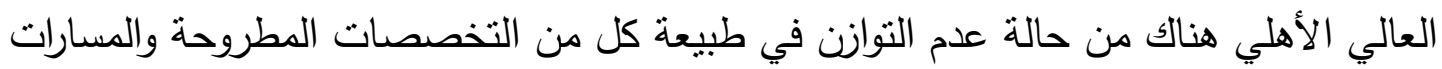

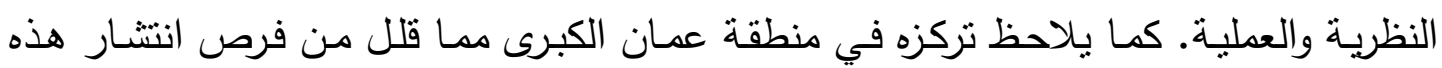

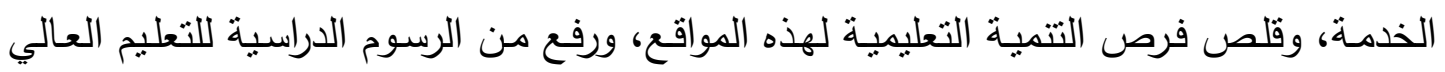
الأهلي.

والواقع أن وزارة التعليم العالي في الأردن تسعى جاهدة لضبط الجامعات والكليات الأهلية

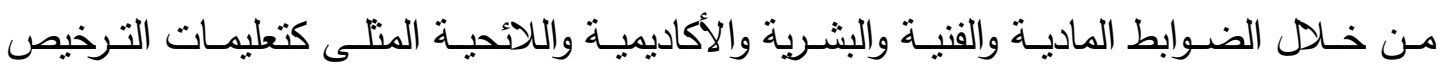
والاعتماد للجامعات والكليات الأهلية وتعليمات المجالس وأعضاء الهيئة التخريسية والفنية والمنابعة

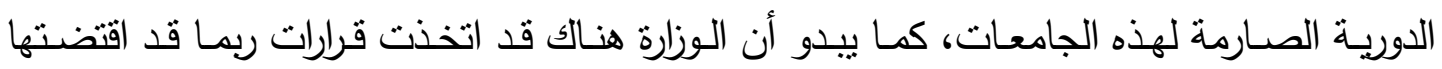
ظروف ذلك الوقت، فأصدرت موافقتها لإنشاء هذه الجامعات خلال فترة وجيزة قياسيا وبأعداد كبيرة نسبيا مـع السماح لمعظم هذه الجامعات بقبول الطـلاب ومباثـرة التدريس بعد استيفاء المعايير الإنثائية (معايير الاعتماد العام) دونما مراعاة لاستيفاء هذه الجامعات للبنى التتغيلية الأكاديمية

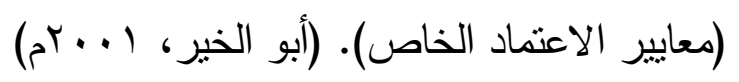

ثالثًا: تجربة التعليم العالي الخاص في الإمارات الفات العربية العية المتحدة:

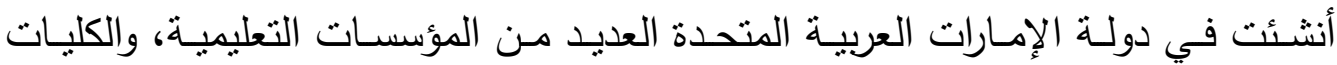

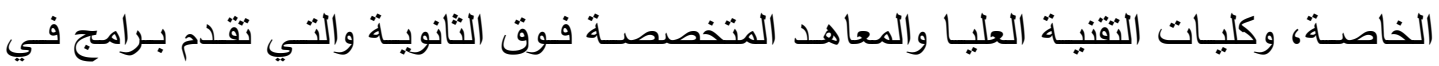

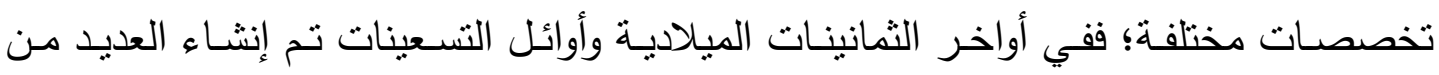

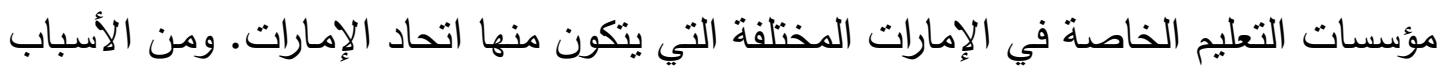

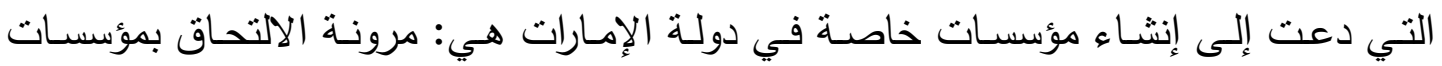

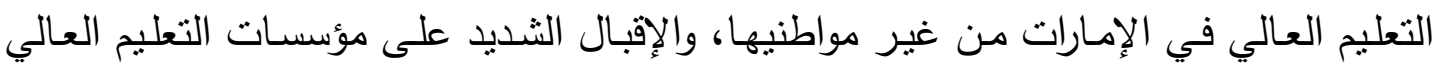

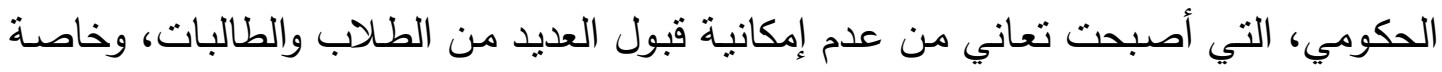

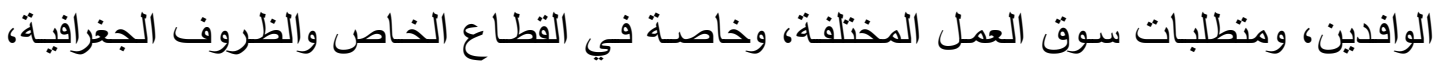
وتفضيل الطلاب للاراسة في كليات ومعاهد قريبة من مساكنهم. 
ومـن الجامعـات والكليـات الخاصـة فـي دولــة الإمـارات الآتـي: جامعـة عجمـان للعلـوم

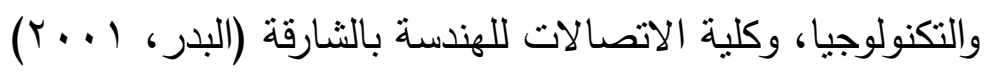
نمط التعليم الجامعي الخاص في الأمارات:

نمط الخصخصة المعتدلة هو النمط المتبع في الجامعات الخاصـة في دولة الإمارات

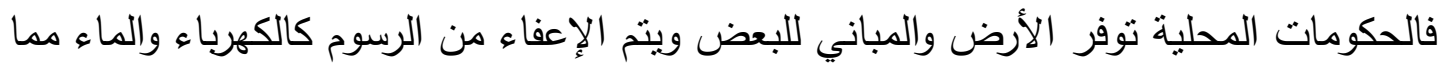

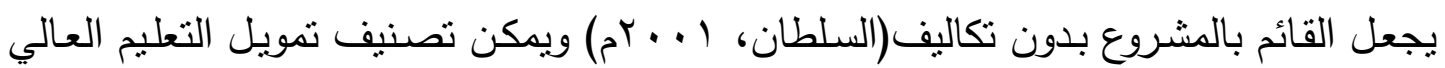

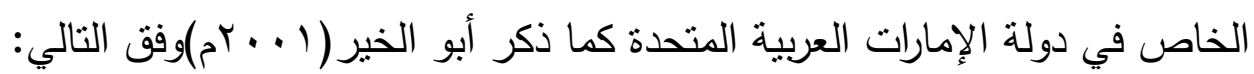

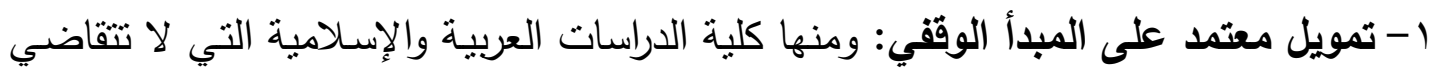

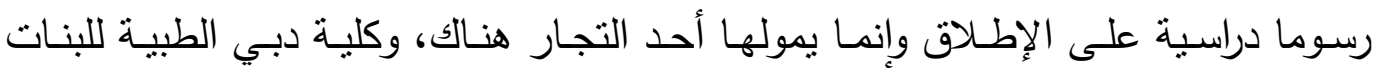
الوقفية ولكنها تنقاضى رسوما لتتغيلها. r- تمويل معتمد على المؤسسات ذات العلاقة: ككلية الاتصالات للهندسة التي تمولهات التها مؤسسة الإمارات للاتصالات، وكلية دبي للطيران التي تمولها وتترف عليها شركة طيران الخليج.

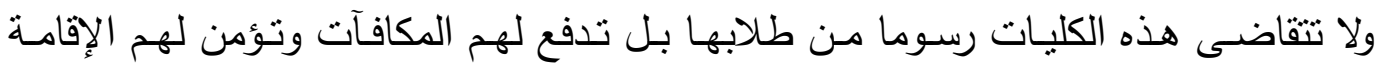
والإعاثة. وفي الغالب أن خريجي هذه الكليات سيعملون في المؤسسات التي تتبع لها هذه الكليات. ץ- تمويـل ربحي محضض: كجامعـة عجمـان للعلوم والتكنولوجيا والجامعـة الأمريكية وجامعـة الثنارقة على سبيل المثال لا الحصر .

التجربة أفرزت مزايا عديدة وإيجابيات للمجتمع وللاقتصاد الإماراتي وللتعليم العالي وهي: ضمان توفر البنية الأساسية لضمان الاستمرارية وضمان الجودة، فالحكومات المحلية

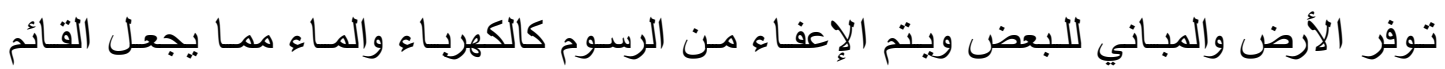
بالمشروع بدون تكاليف، الاستعانة بالخبرات الأجنبية في تطوير التعليم العالي نظراً لعدم توفر الإعراء الخبرات المحلية؛ مها وفر التتويع في التجربـة وخاصـة فيما يتعلق بالمستقبل ودخول الدول

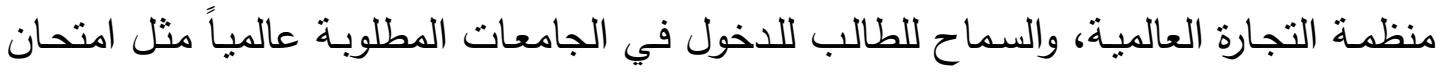
اللغة الإنجليزية (TOFEL)، والعودة لإثراء العملية التعليمية من خلال خلط جنسيات مختلفة

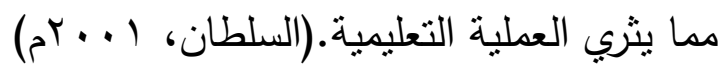
ويمكن تلخيص السلبيات للتجرية الإماراتية في الجوانب التالية: 
تظلب سيادة التخصصات النظرية بشكل عام على التخصصات العلمية، كم أنه يمثل

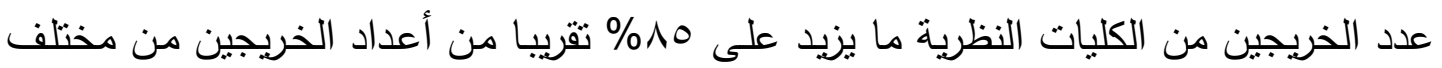

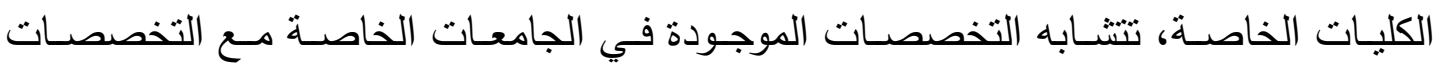

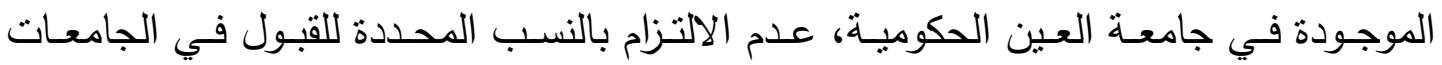
الحكومية لمختلف الكليات، حيث يتم القبول في الجامعات الخاصة إلى نسبة متدنية وريما في

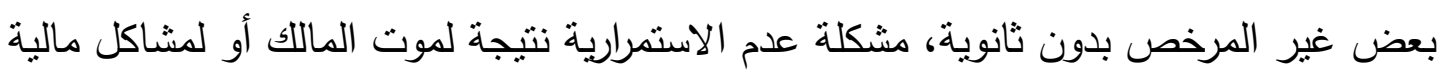
ولا تتوفر خطط لمواجهتها في المستقبل. العشوائية في التخطيط من ناحية تكوين البنية التحتية

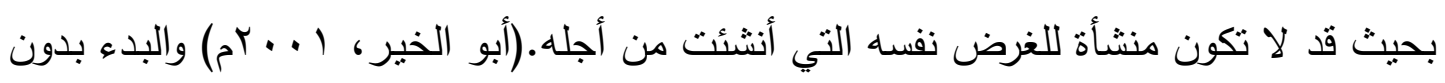
ترخيص سمة ظاهرة في الإمارات وقد تم إغلاق بعض الكليات ولم تمنح تراخيص. التعليم

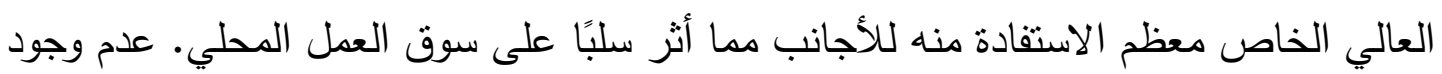

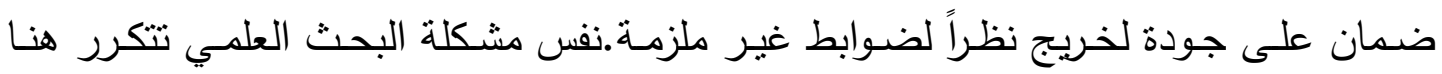

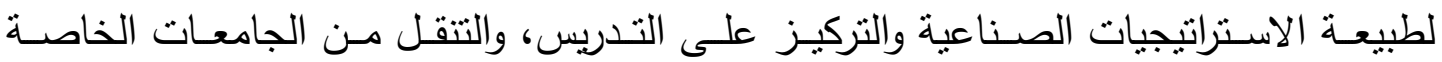

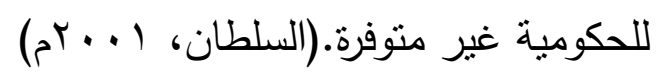
نظــرة تقييميـة:

يتبين مها سبق أنه على الرغم من أن التعليم العالي الخـاص في الإمـارات العربيـة

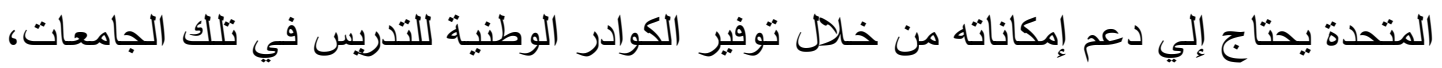

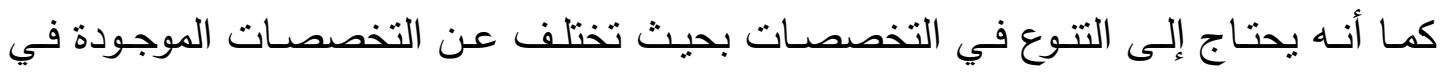

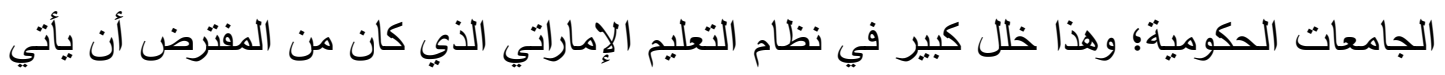

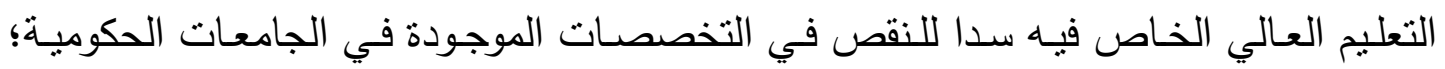
ويعود السبب في ذلك إلي التنافس بين هذه المؤسسات من ناحية ونشوئها بدون تخطيط مسبق

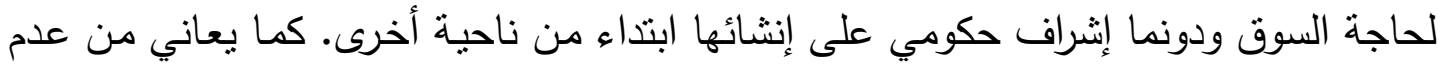

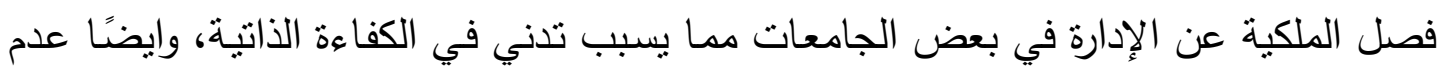

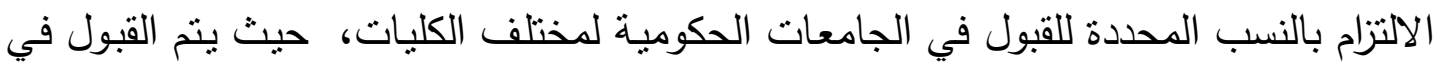

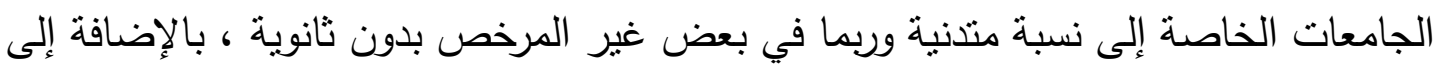

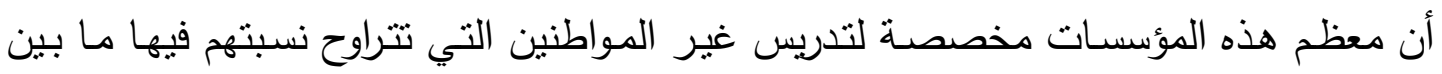
\%10 \% إلي 90\% من نسبة المواطنين المقيدين. 
وعلى العموم نلاحظ أنه يخطو حاليا خطوات مدروسة نتيجة للإثراف الصارم من قبل وزارة التعليم العالي وتقليصها للمؤسسات الغير مرخص لها وإلغائها للتراخيص السابقة وإيقافها لطلبـات التأسيس الحاليـة، ولا شـك أن مسـتقبل التعليم الأهلي في الإمـارات مرهـون بالدور الإثرافي للوزارة ووعي المؤسسين للكليات والجامعات الأهلية والدارسين فيها.

رابعًا: تجربة التعليم العالي الخاص في الولايات المتحدة الأمريكية:

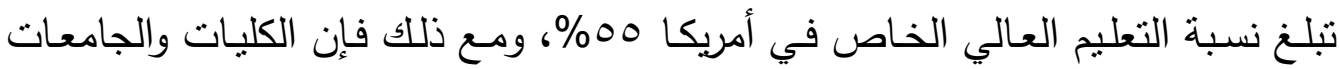

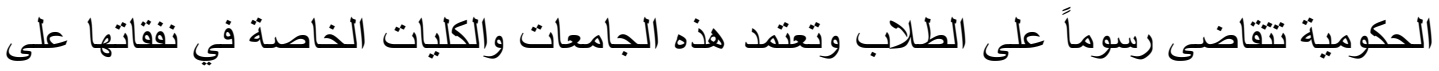

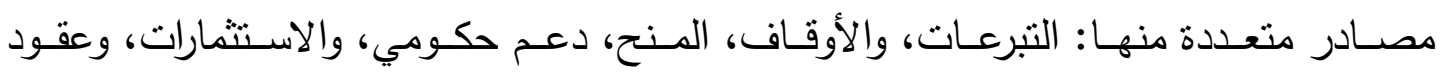

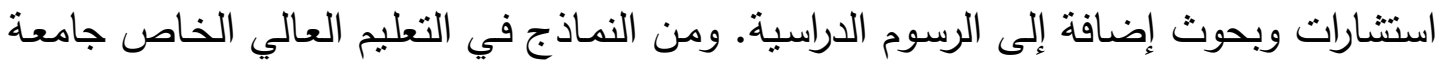

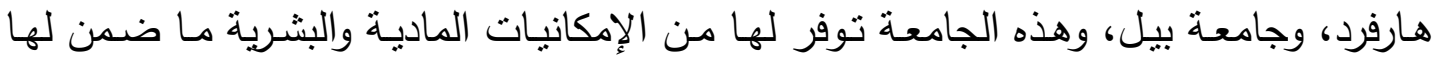

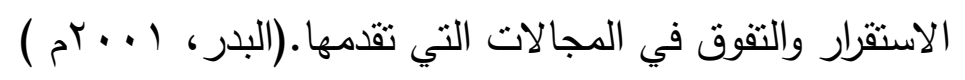

وقد وضح كعكي ( ا. - rم) تتمتع الكليات والمعاهد والجامعات باستقلالية كبيرة، حيث تقوم بإدارة شئونها التعليمية تبعاً لنصوص دستورية خاصة بكل ولاية، فالتتظيمات والمؤسسات

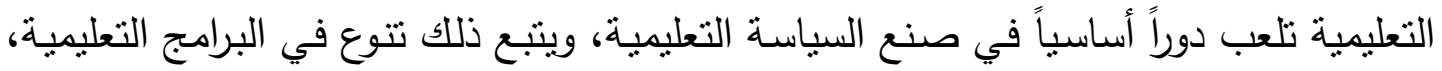

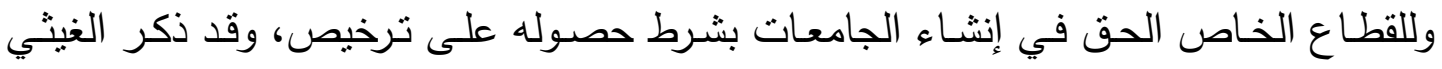

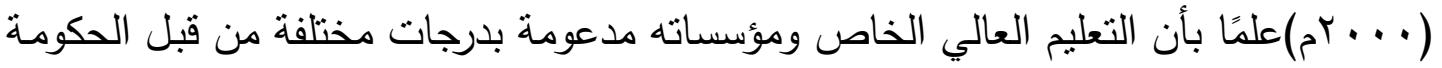

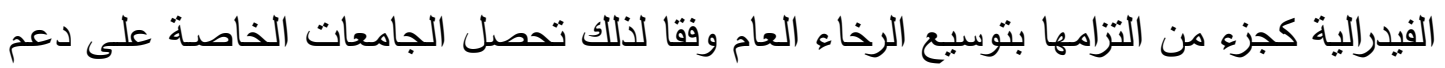

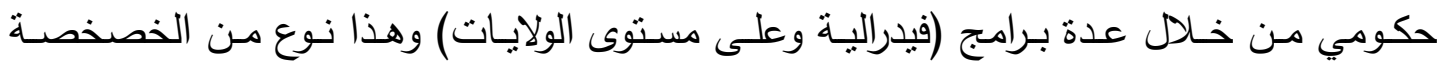

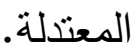

\section{أولاً: الدعم والمساعدات الفيدرالية للقطاع الخاص في التعليم العالي:} تقدم الحكومة الفيدرالية الأميركية دعما غير مباشر لمؤسسات التعليم العالي الخاصة

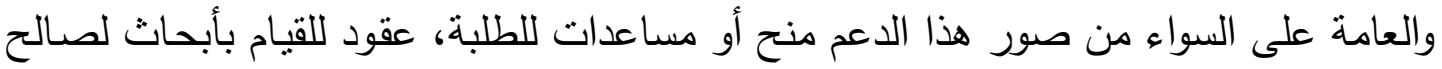

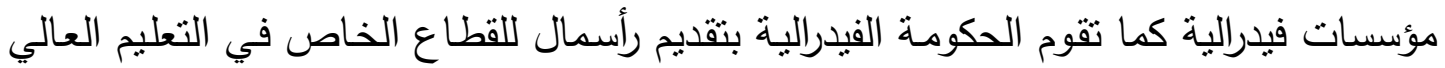
ولكن بطريقة محدودة وانتقائية، ومن صور هذا الدعم للطلبة في مؤسسات التعليم العالي: منح الفرص التعليمية الأساسية وهي مساعدات تقدم مباشرة للطلبة على أساس الحاجة المالية للطلبة (للفقراء والمحتاجين)، منح الفرص التعليمية المكمل /الرديف، منح حوافز للطلبة مناصفة بين

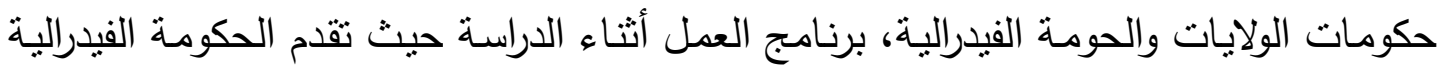

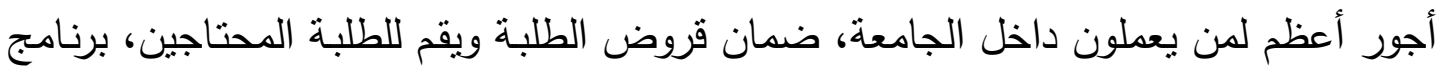


قروض الطلبة القومي المباشر ولا يدفع الطلبة أب فوائد طالما يعملون في السلك الحكومي وعند

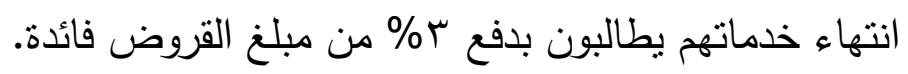
وهناك دعم فيدرالي للبحوث يخدم هدفين: تقدم المعرفة وبالثالي تحافظ على تقدمها البحثي في

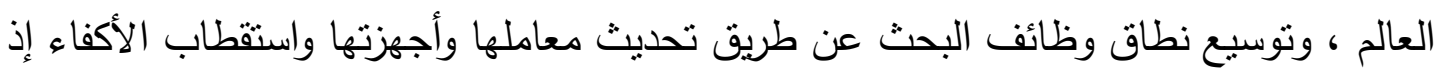

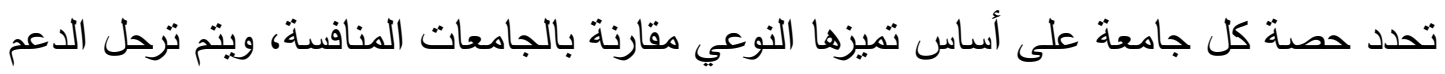

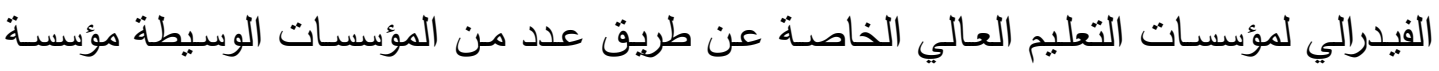

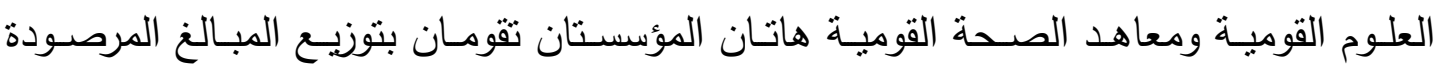
للبحوث على أساس علمي ومحايد بواسطة علماء محكمين من ذوي الخبرة والاختصاص.

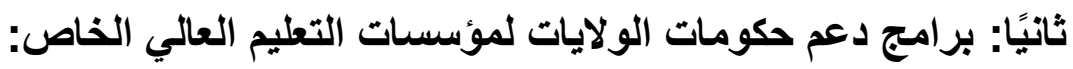

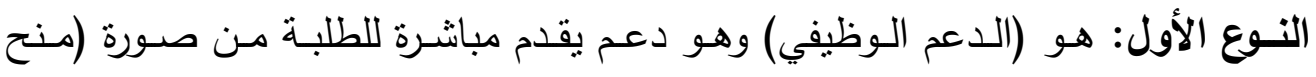

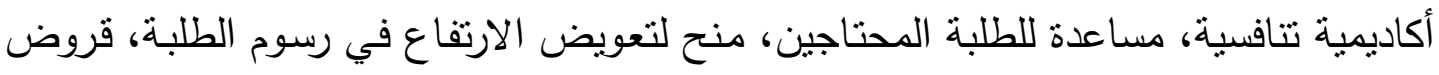
للطلبة المحتاجين). أما النوع الثاني: هو ( الدعم المؤسسي) وهو يقدم مباشرة لمؤسسات التعليم العالي

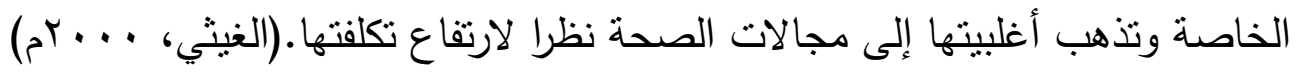

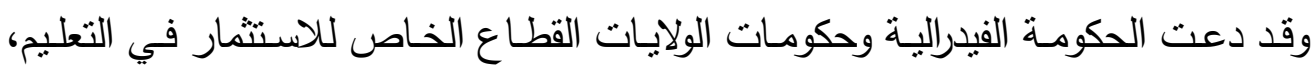

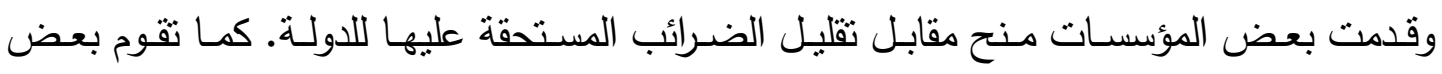

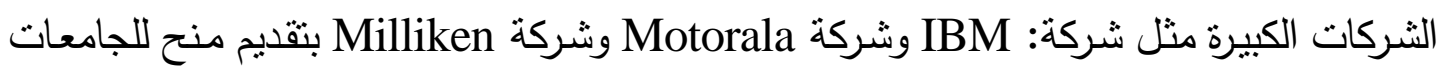

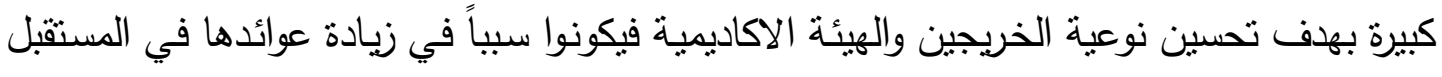

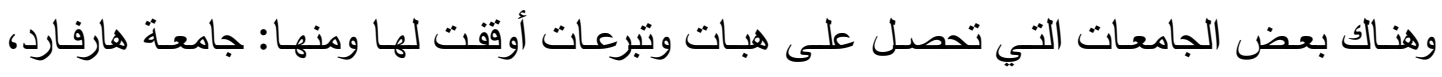

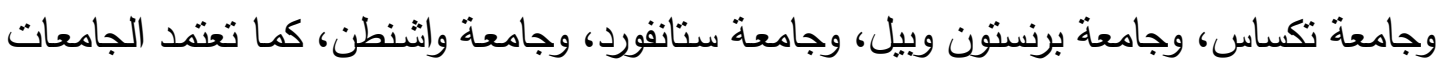

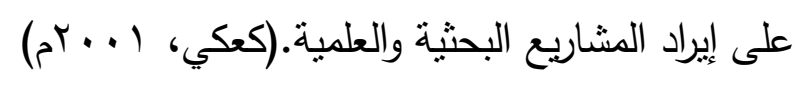

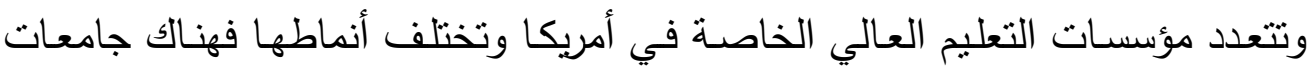
بحثية ونظرية ونطبيقية وهناك جامعات تطبق التعليم العالي التعاوني بشكل موسع في التئي الولايات

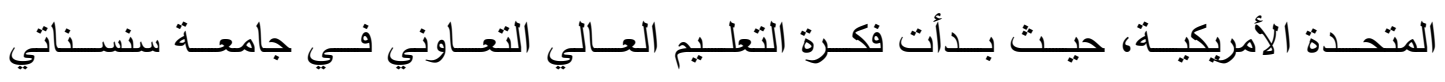
(CINCINNATI)

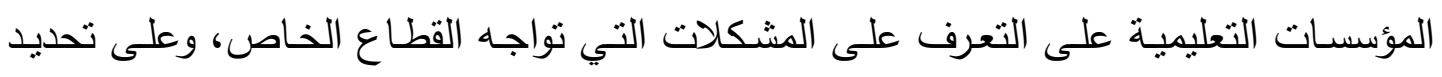


احتياجاته من القوى العاملة المتخصصة كما بساعد على تطوير المعلومات التقنية، والأبحاث

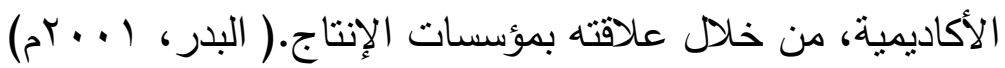

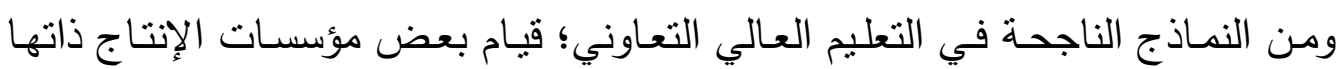

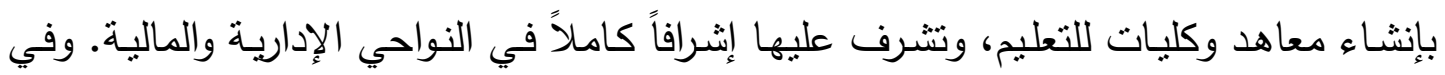

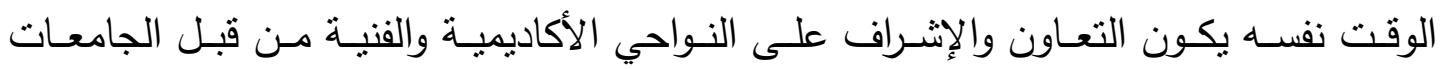

$$
\text { ومؤسسات التعليم العالي. }
$$

ومـن الكليـات التي تطبـق التعليم العـالي التعـاوني بأمريكـا كليــة رامـابو الجامعيـة

(Ramapo)

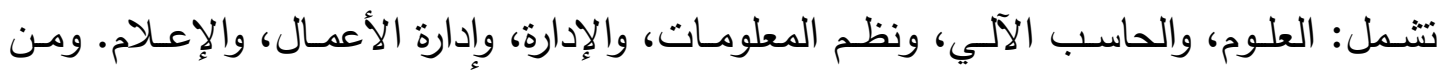

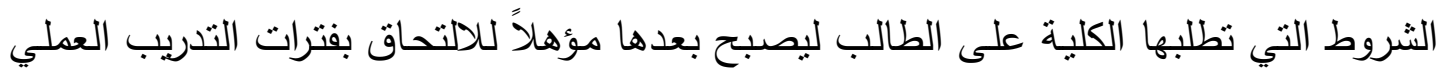

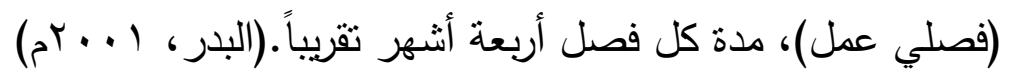

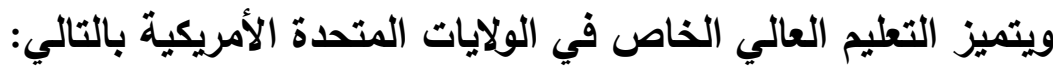

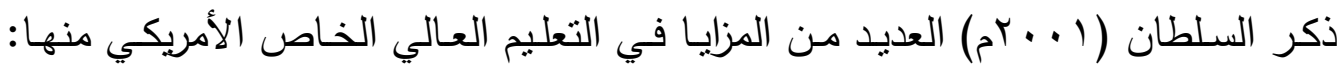

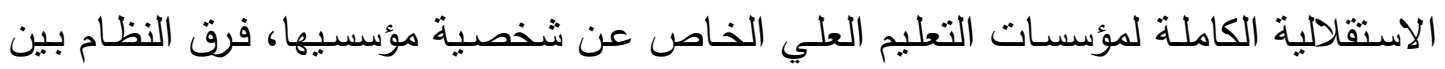
مصالح المؤسسين ومصالح المؤسسة التعليمية وبصورة واضحة وترك مجال الربحية من خلال

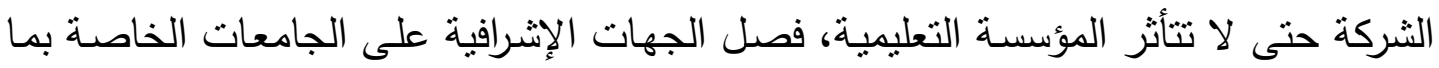
يتلاءم مع نطلعات الراغبين في الاستفادة، يعتمد على نظام له رقابة ذاتية ويحرص على تطبيق

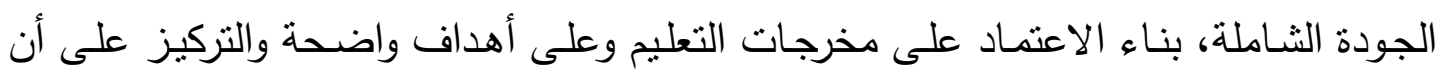

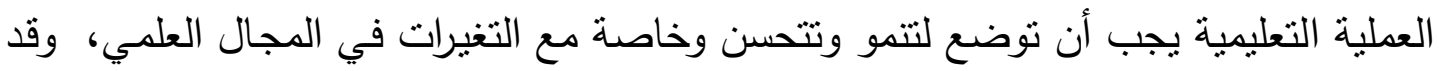

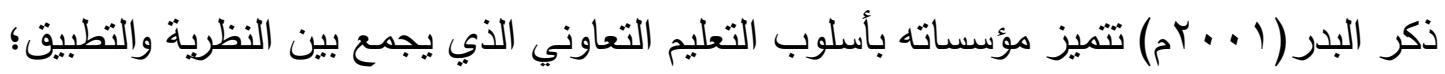

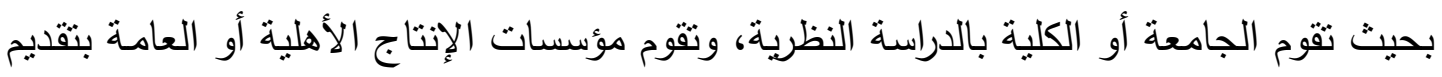

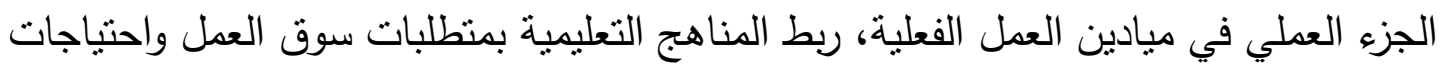

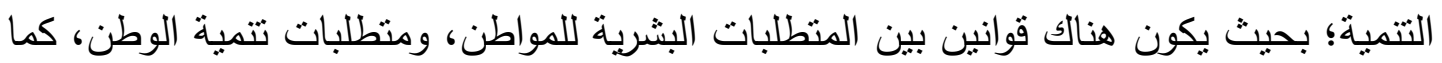

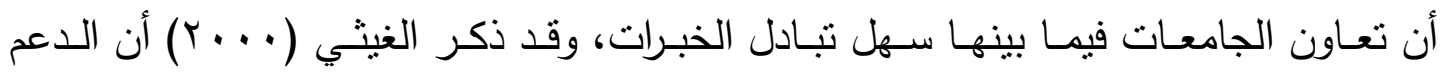

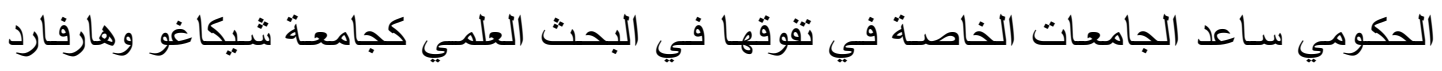

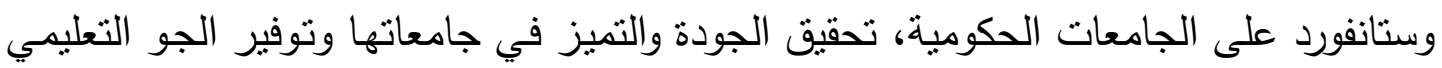
الملائم لطلابها جعل بعضها تتنقي الطلبة المتميزين فقط وتكون لصفوة الطلاب حيث يتوفر للى هذه الجامعات آلية لاستقطاب الطلاب والأساتذة المتميزين (جامعات انتقائية). 


\section{ويمكن أن نحصر عيوب النظام في النقاط التالية وهي:}

ا - الحصـول على الاعتمـاد اختيـاري على مستوى التخصص وليس إجباري وبالتالي هنالك مؤسسات غير معتمدة في التخصصـات الفرعي، .إعطاء الخيار للمؤسسـات التي ستفشل في الاعتماد التخصصي في الانسحاب قبل إتمام العملية. (السلطان، ( +. بام )

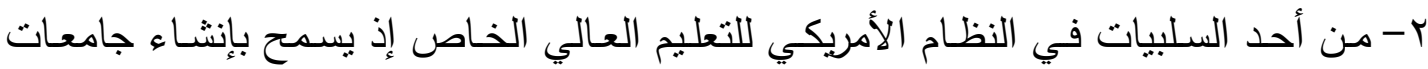
تخص (ثقافة الأغلبية) وهي تلبي ثقافة جماعة معينة ومعتقداتها الدينية والطائفية فتجد في هـذه المؤسسـات الخاصـة تلبيـة لأذواقهم وتمـول بالكامـل مـن قبـل الجماعـة والطائفـة

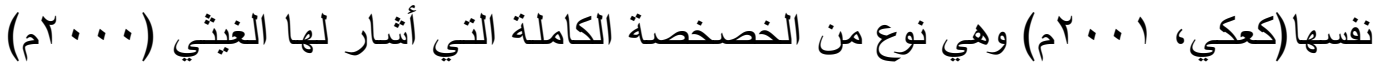
حيث أنها تهدف لترويج فكر ثقافي أو سياسي أو ديني معين، وهذه تعد أحد أكبر أخطار الخصخصة الكاملة، التي تكون فيها الإدارة من قبل الجهات والأفراد الممولين وتدخل الدولة فيها محدود ويكاد يكون معدوم؛ فتأتي هذه الجهات وتفرض نوع من التعامل مع المستقبدين من هذه الجهات؛ وبالتالي تجميع أكبر قدر من المؤيدين لتوجههم أو فكرهم أو الإيديولوجية التي يتبعونها.

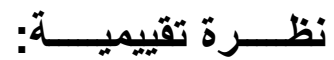

يعتبر النظام الأمريكي والمطبق في التعليم نتاج خبرات أكثر من قرنين من الزمان مـع كبر حجم السوق حيث بدأ التعليم الخاص (الأهلي غير الربحي) تلاه التعليم الحكومي. ويعتبر النظام الحالي متوازن من حيث الطلب والعـرض وتوفر الآليـة التي تضـمن استمرار الكفاءة وخاصة من خلال دعم الحكومة الفدرالية. يعتبر من أكبر المعوقات المؤثرة على سبر العملية التعليميـة حيث يكون تغليب الهدف الربحي سبباً في التأثير على الهدف الآخر في العمليـة التعليميـة وهي المخرجات سواء كانت طـلاب أو في عمليـات البحث والتطوير ، ولكن تدعيم الثاني على الأول ممكناً وفي حدود لا ضرر ولا ضرار وذلك من خلال جهة خارجية حياديـة تحرص على وجود مقاييس نؤدي لتحقيق الهدفين مثل النظام الأمريكي حيث يوفر جهة خارجية

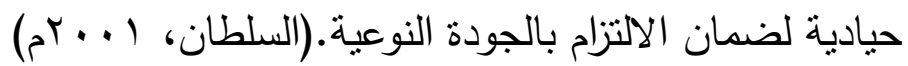
كما أن برامج المنح المقدمة من جهات مختلفة للطلاب والأساتذة ساعدت مؤسسات التعليم العالي الخاص من وضع مستوى مقبول من التعليم مع ارتفاع الرسوم للطلبة دونما خوف من نفور الطلبة بسبب ارتفاع الرسوم، كما ساعد الطلاب الغير قادرين ماديين من الالتحاق بهذه الجامعات والكليات الخاصـة وبالتالي حقق مبدأ العدالة والمساواة في تحقيق الفرص التعليمية، كما إن هنالك علاقة قوية بين تدخل الدولة في شؤون المؤسسة التعليمية وبين مقدار التمويل المقدم من الدولة؛ 
فكلما زاد التمويل زاد التدخل ويتمثل في شؤون الموظفين، الحقوق الدنيـة، شؤون الطلبة، حيث

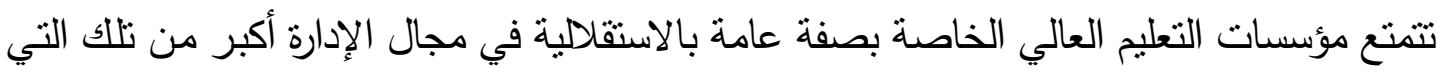

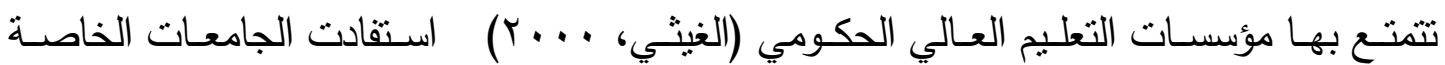
بالمتقاعدين حيث تعمل الجامعات بالتعاون مع الأثخاص فوق سن 00 على إيجاد فرص العمل

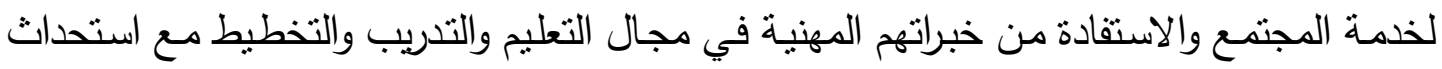
مراكز لهم. (R obert,1992)

يتبين من العرض السـابق أن التعليم العالي الخاص بمختلف مؤسساته يعتبر حاجة التها

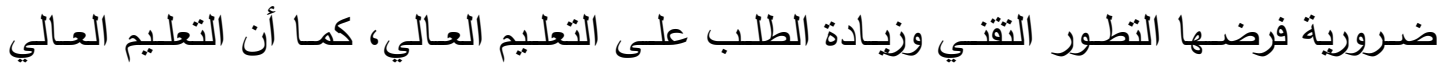

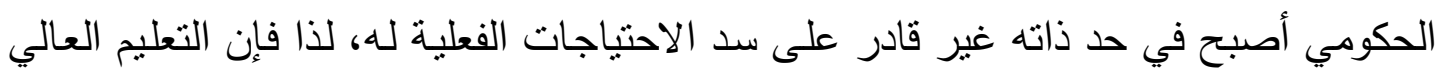
الخاص سيمكن من تخفيف الضغط على التعليم الحكومي، كما سيمكن من فتح تخصصيات

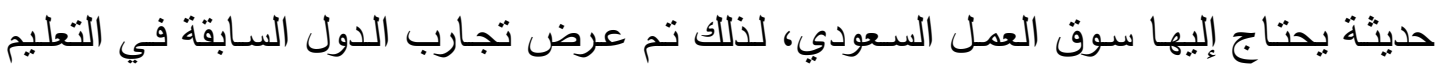

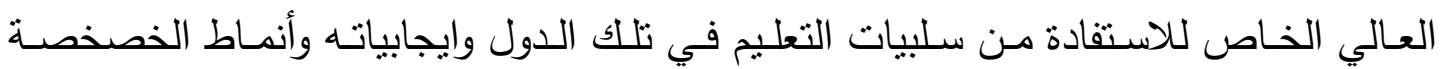
المطبقة لديه مما سيعود بالنفع على التعليم العالي الخاص في المملكة العربية السعودية؛ حيث

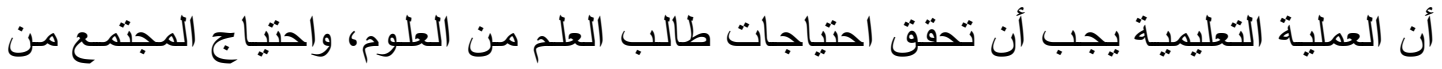

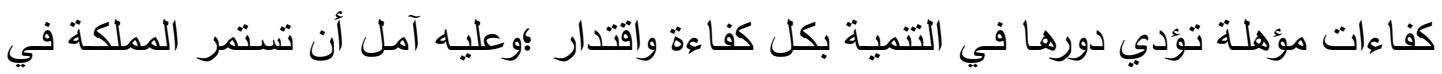

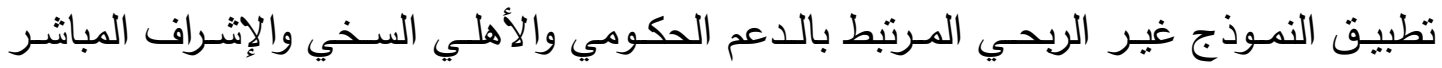

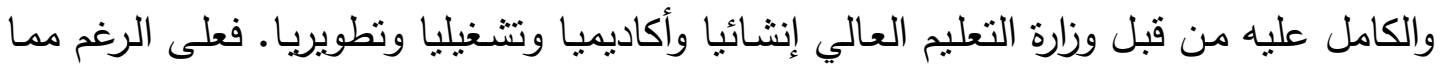

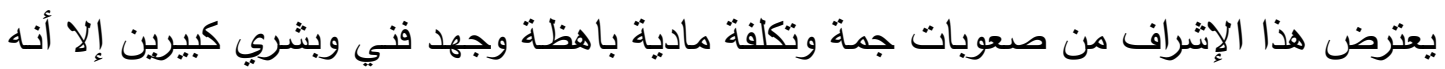

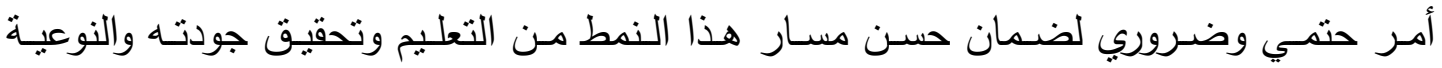

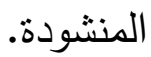

\section{وكما توصلت الباحثانة من العرض السابق:}

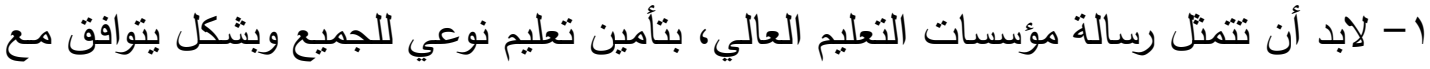
متطلبات التتمية واحتياجات سوق العمل بحيث يبني الثخصية المتكاملة والمتوازنة للمواطن

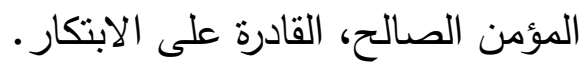

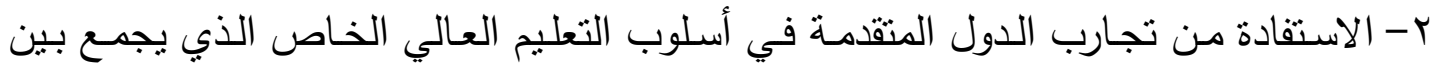

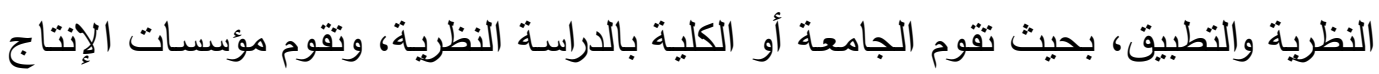
الأهلية أو العامة بتقديم الجزء العملي في ميادين العمل الفعلية. 
ץ- إيجاد أنماط جديدة للمؤسسات التعليمية تحقق التمايز مثل: الجامعات التخصصية، البحثية التطبيقية، والتخصصات البيئية.

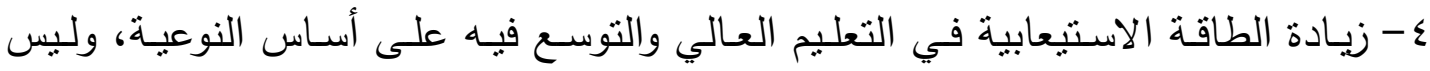

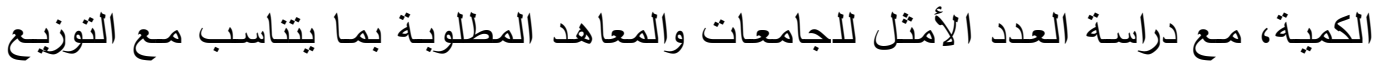

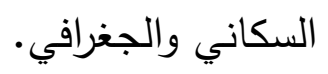

ختامًا، تبين أن كثبراً من الدول تعتمد على التعليم مادون الجامعي وعلى أنماط أخرى في مرحلة التعليم العالي، وهذا ما تفتقده في برامجنا.

\section{المبحث الثالث : تجربة المملكة العربية السعودية في خصخصة التعليم العالي :}

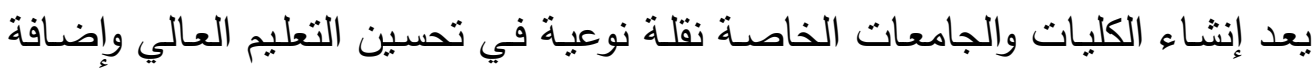

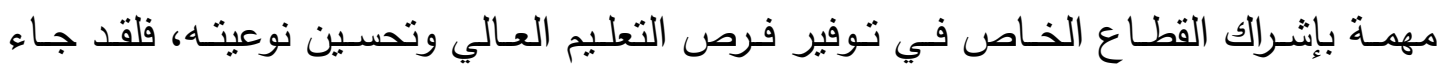

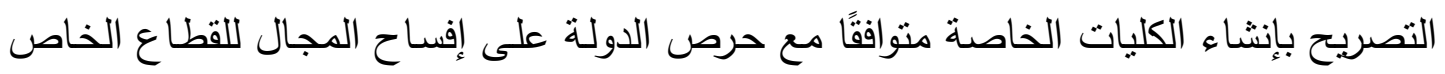

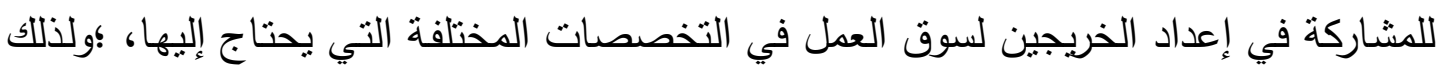

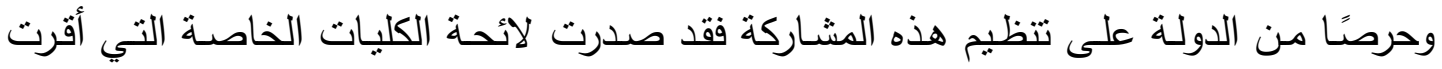

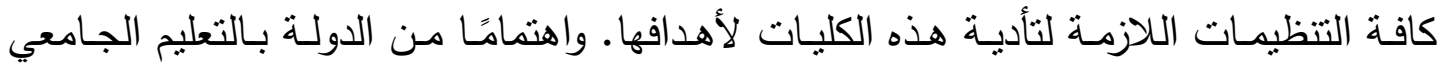

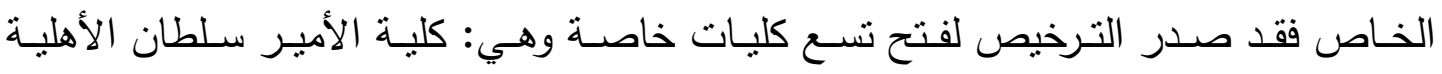

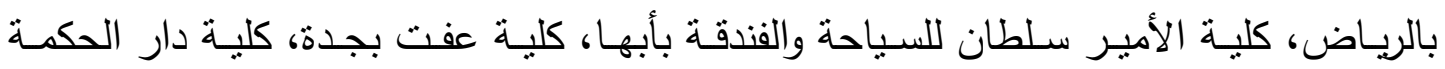

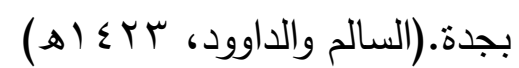
أولاً: أهداف التعليم العالي الخاص:

لا يختلف التعليم العالي الخاص عن الحكومي في الأهداف العامة فكل منهما يستهدف

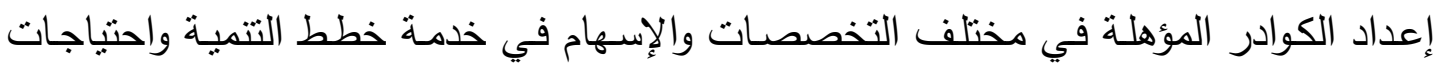

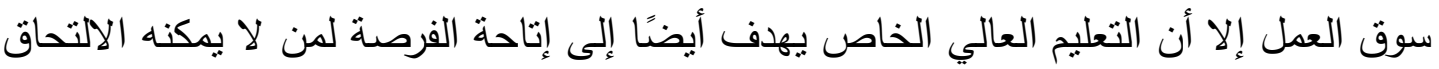

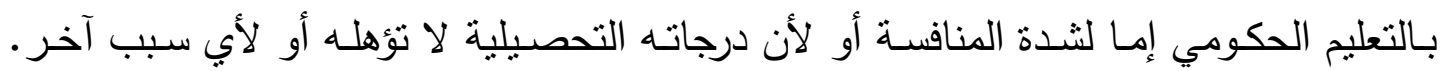

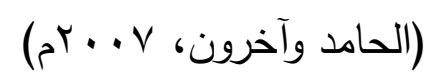

ثنائًا: نمط التعليم العالي الخاص في مؤسسات التعليم العالي في المملكة العربية السعودية: التعليم الجامعي الخاص الربحي وغير الربحي المدعوم من الدولة فئلة حيث عملت وزارة

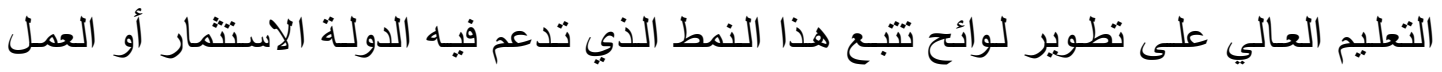

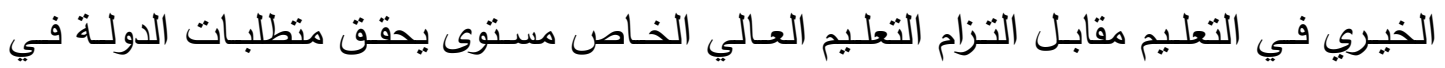

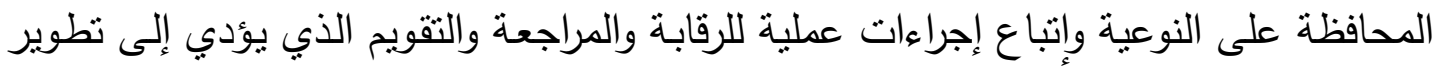

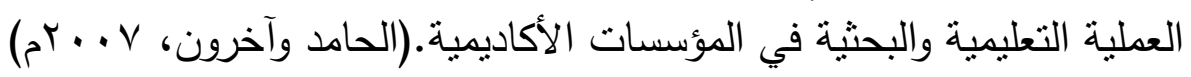


منذ إقرار الدولة للائحة الكليات الخاصـة والعمل جار في وزارة التعليم العالي لوضـع

القواعد المنظمة لتشجيع الكليات الخاصة وقد نمخضت تلك الجهود بصدور قرار مجلس الوزراء

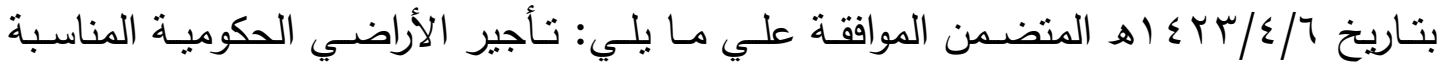
التابعة لوزارة الثؤون البلدية وغيرها من الجهات بأسعار رمزية.، قيام وزارة المالية بتقديم قروض ميسرة للكليات الخاصة المرخص لها، قيام وزارة التعليم العالي مع المالية بتقديم حوافز إضـافية لإنشاء الكليات في المناطق التي تحتاج إليها.

بالإضـافة إلى المزايا سالفة الذكر فإن الوزارة تضع حوافز تشجيعية كدعم مباشر أو غير مباشر فالدعم المباشـر مثنل: الإعفاءات الجمركية لتجهيزات الكلية، الإعفاء من رسوم التأثيرات، تخفيض رسوم الكهرباء والماء، تخفيض رسوم الانترنت. أما صور الدعم الغير مباثر فمثل تقديم

$$
\text { إعانات أو قروض للطلبة الدارسين في الكليات. (الحامد وآخرون، V . . rم) }
$$

من العرض السابق نتوصل إلى أن حكومة المملكة العربية السعودية قد أولت اهتمامًا كبيرًا ومتزايدًا بتتمية الموارد البشرية فخصصت لهذا الغرض نسب عالية من الاعتمادات المالية في خطط التتمية وشجعت القطاع الخـاص للمشـاركة في ذلك الاهتمام ؛ونتيجة لذلك أتيحت فرص التعليم العالي في المملكة لأعداد كبيرة من خريجي الثانويـة الأمر الذي أدى إلي تزايد

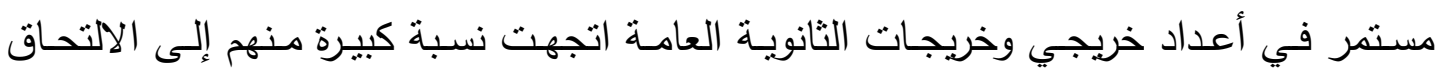
بالجامعات الحكومية والخاصة.

رابعًا: مبررات التعليم العالي الخاص في المملكة العربية السعودية:

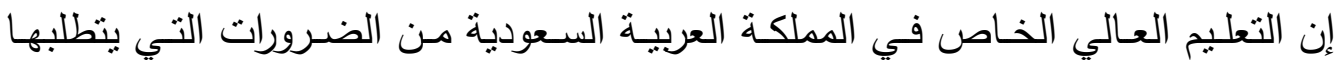
الوضـع الراهن، وهناك عدة مبررات تختص فيها طبيعة البيئة السعودية ومشكلاتها نساهم في التوجه للتعليم العالي الخاص ومنها ما يلي:

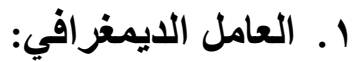

يمثل السكان عامل مهم عند التخطيط للتعليم العالي, وتميزت المملكة بمميزات خاصـة للسكان من جانبين:

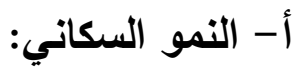
النمو السكاني في المملكة العربية السعودية يتميز بنسبة زيادة طردية نظرا لطبيعة المجتمع

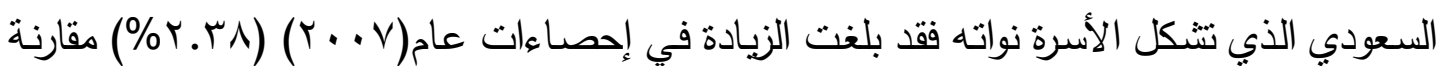




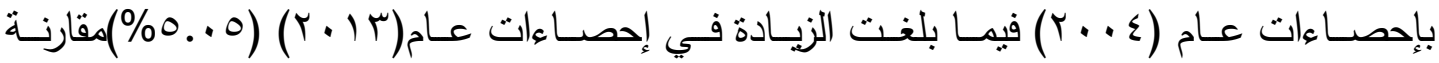

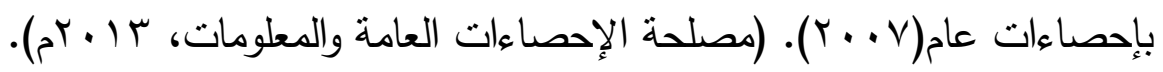

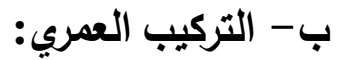

يعتبر المجتمع السعودي مجتمعًا فنيًا من الناحية الديمغرافية فقد بلغت نسبة من تقل

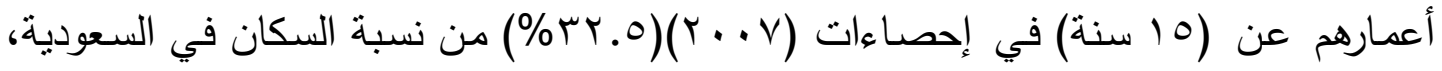

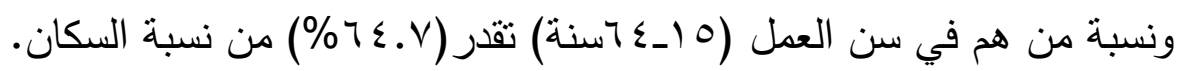

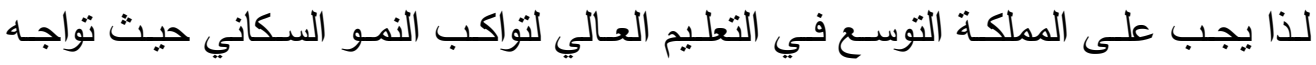

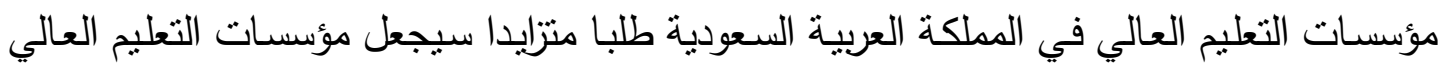
غير قادرة على استبعاب المزيد من المتقدين، فقد وصلت الطاقة الاستبعابية للجامعات ذروتها، ولم تقتصر زيادة عدد الملتحقين عن الطاقة الاستيعابية في الجامعات والكليات الأكاديمية، وإنما

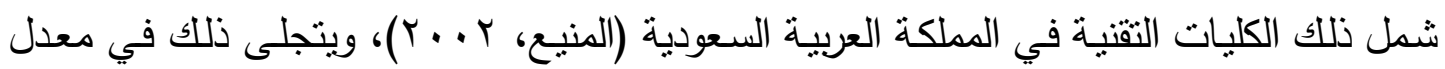

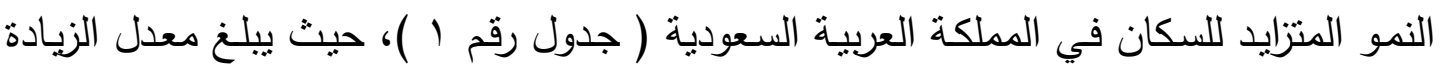

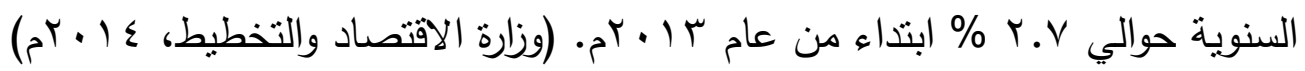

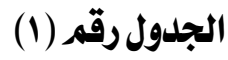

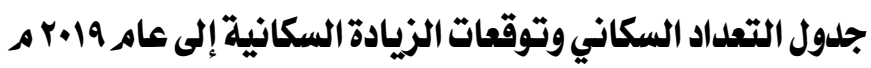

\begin{tabular}{|c|c|c|}
\hline معدل الزيادة السنوية & علد السكان & السنة \\
\hline ........... & rVOTTEYT & r.1. \\
\hline$\%$ r.r & ra99ErVr & r.lr \\
\hline$\% r . r$ & TrYEAIYT & $r .19$ \\
\hline$\% 1.9$ & TEYYOETO & $r .19$ \\
\hline
\end{tabular}

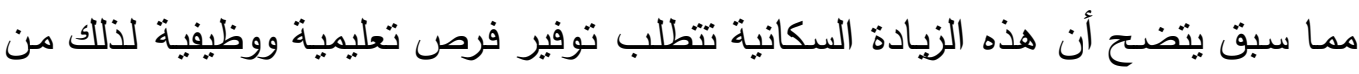

الضروري التوجه إلى زيادة استيعاب مؤسسات التعليم العالي، وهذا لا يتم إذا ما بقي التعليم معتمدًا

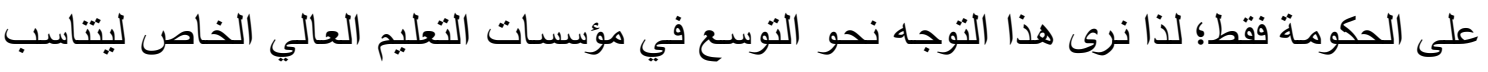
مع معدلات زيادة النمو السكاني

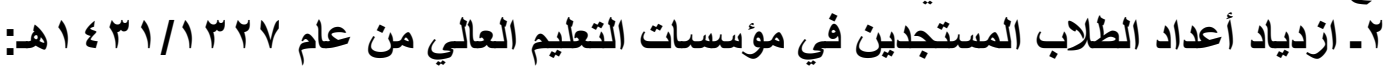

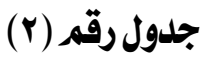

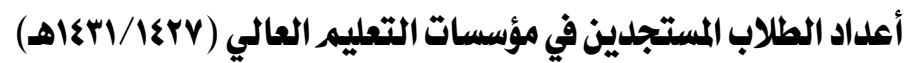

\begin{tabular}{|c|c|c|c|c|}
\hline$|\& H|$ & l\&t. & I\&Yq & IEFA & IEYV \\
\hline
\end{tabular}




\begin{tabular}{|c|c|c|c|c|c|}
\hline rav. Trt & TYY.AOS & roo. $7 \mathrm{rI}$ & TrY.YAE & MIY.YAI & إجمالي الطلاب المستجدين \\
\hline$r V .1 r q .9 V V$ & PO.rYT.01E & $r \xi . \Lambda \cdot V . r Y r$ & Y\&. YSY.OVA & Mr.TVA.ASQ & إجمالي علد السكان \\
\hline $1.99 \mathrm{~V}$ & $1 . \cdot v 0$ & $1 . \cdot r \cdot$ & $9 \xi$. & qr. & عدد المستجدين لكل (•.1) ألف \\
\hline
\end{tabular}

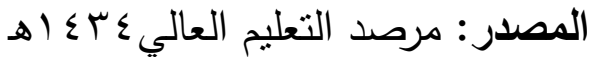

يبين الجدول رقم( r ) مؤشر عدد المستجدين لكل ( · · ( ) ) ألف من السكان خلال الفترة

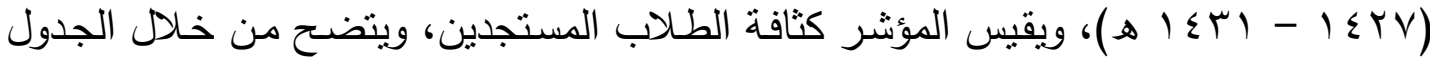

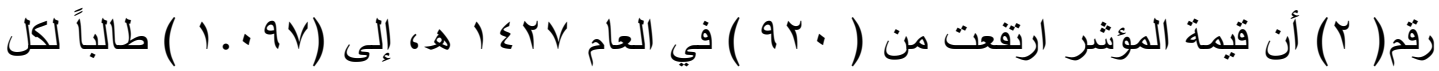

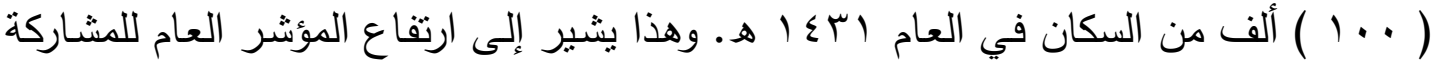
في التعليم العالي وتحسنه، الذي نتج بشكلٍ أساسي عن الارتفاع الكبير في أعداد المستجدين الذكور • (مرصد التعليم العالي عبء اهـ ) ويستخلص من العرض السابق أن الاهنمام بالتعليم الخاص الجامعي فرضه واقع ارتفاع الوعي بأهمية التعليم والرغبة في استكماله من التعليم العام إلى التعليم العالي والزيادة المطردة في أعداد خريجي وخريجات الثانوية العامة بما يفوق وبشكل كبير الطاقة المتاحة لقبول الطلاب بمنشآت التعليم العالي الحكومسي لذلك اتجهت الدولة إلى تشجيع القطاع الخاص للاستثمار في قطاع التعليم العالي وذلك لاستيعاب الكم الهائل من خريجي الثانوية.

r- نمو الإنتاج البحثي للمملكة حسب تصنيف (Scopus) جسـول رقم (r)

الإنتاج البحثي للمملكة حسب تصنيف إنس

\begin{tabular}{|c|c|c|c|c|c|c|c|}
\hline نسبة النمو الكلية & معدل النمو السنوي & $|\xi H|$ & 1हr. & 1Erq & IEYA & IEYY & السنة \\
\hline$\% 90$. & $\% 1 \Lambda .\{$ & S.V... & r. YOY & $r .9 \leq V$ & r. $7 r q$ & r.\&l. & عدد البحوث \\
\hline
\end{tabular}

المصدر: مرصد التعليم العالي ع ع اهـ

يوضح الجدول رقم ( r ) الإنتاج البحثي في المملكة حسب تصنيف الدوريات المحكمة خلال الفترة( Scopus)

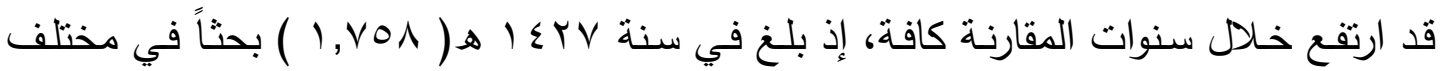

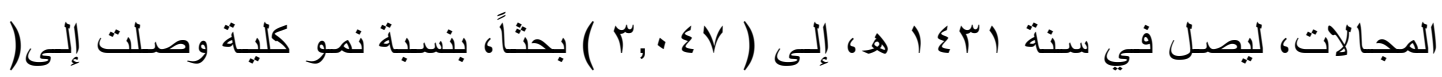

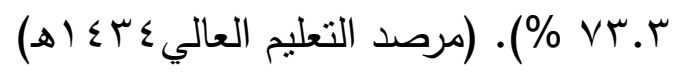




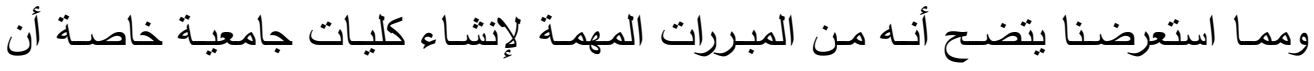
تستهدف هذه الكليات الإسهام في نمو الإنتاج البحثي للمملكة لمقابلة التوسع في البحث العلمي وما يصاحبه من زيادة التكاليف من عام لآخر، كما أنه من الضرورة أن يكون هناك مركز

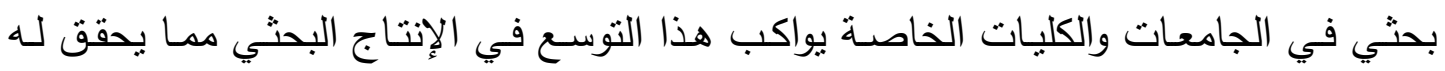
المنافسة مع الجامعات الحكومية المحلية والعربية والعالمية.

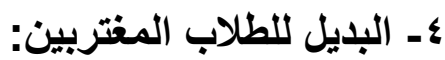

الجامعات الحكوميـة لا تتيح تسجيل الطـلاب المقيمين بنسب كبيرة فيما وفرت لهم الجامعات الخاصة البديل لمتابعة إكمال دراستهم فقد بلغت نسبة الطلاب المقيمين المسجلين في

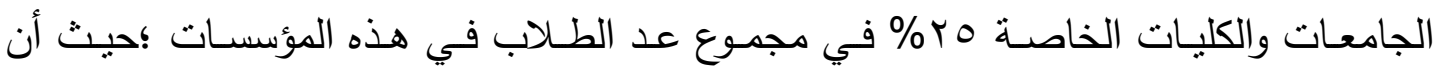

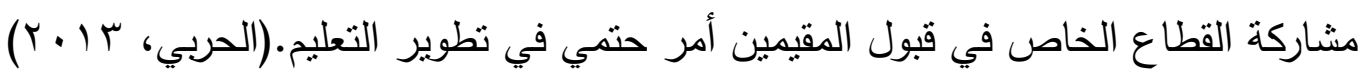

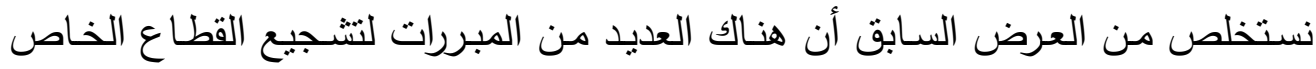

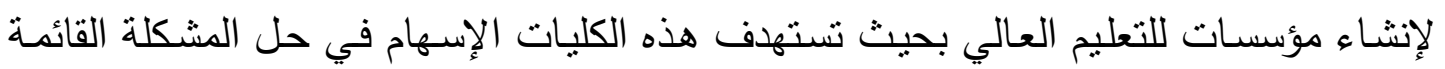

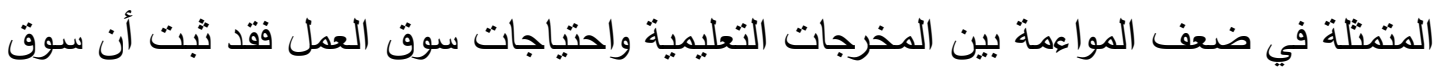

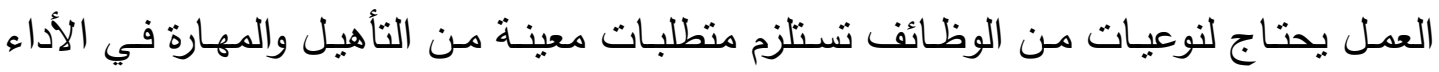

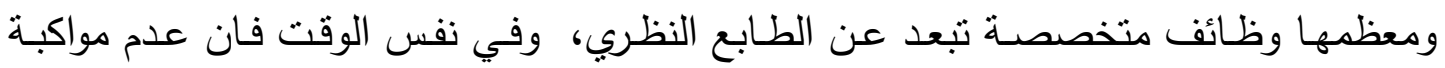

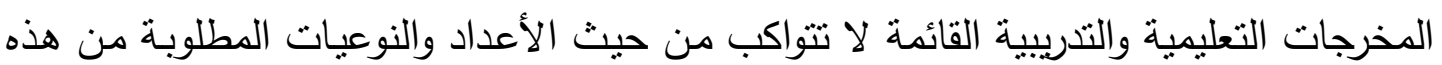
- الوظائف

خامسًا: نمو عدد الجامعات والكليات الخاصة:

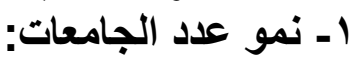

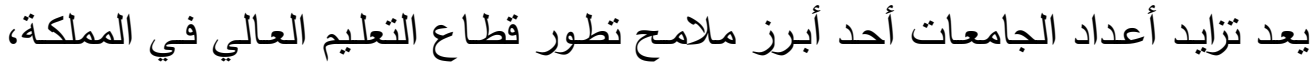

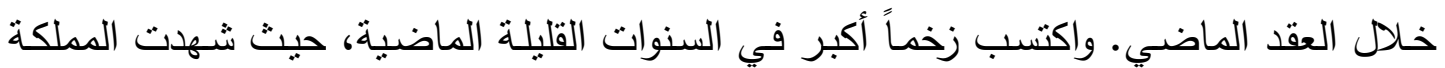
حراكاً غير مسبوق في إنثـاء الجامعات، وتوسعة القائم منها، باستحداث الكثير من البرامج والتخصصات.

\section{جدول رقم (₹)}

نمو علد الجامعات في المملكة (\&YO/IEO

\begin{tabular}{|c|c|c|c|c|}
\hline نسبة النمو الكلية & $|\varepsilon r|$ & IETO & \multicolumn{2}{|c|}{ السنة } \\
\hline$\% 111$ & r乏 & 11 & حكومية & \multirow{2}{*}{ علد الجامعات } \\
\hline$\% 1 \ldots$ & $\wedge$ & $\varepsilon$ & خاصة & \\
\hline
\end{tabular}




\begin{tabular}{|l|l|l|l|l|}
\hline$\% 11 r$ & rr & 10 & إجمالي & \\
\hline
\end{tabular}

المصدر: مرصد التعليم العالي ع إ اهـ

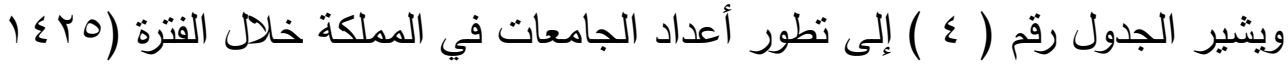

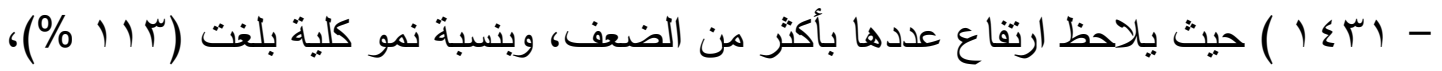

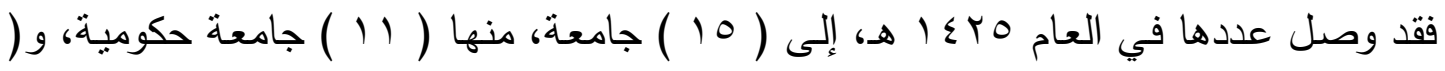

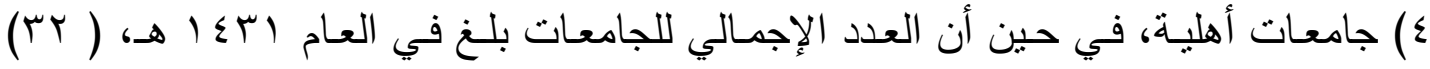

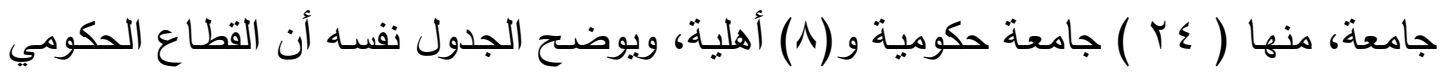
هو الذي قاد النطور في هذه المرحلة، حيث تجاوز النمو في عدد الجامعات الحكومية النمو

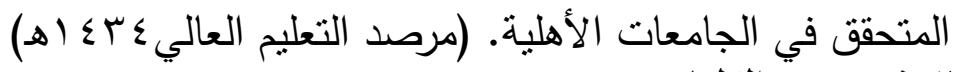

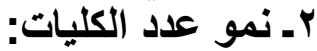
وكما هو حال الجامعات الأمر نفسه ينسحب على الكليات، حيث ارتفعت أعدادها بشكلٍ كبيركما هو موضح هو هال

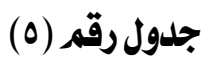

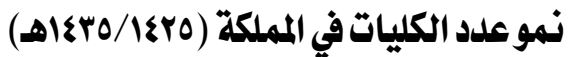

\begin{tabular}{|c|c|c|c|c|}
\hline نسبة النمو الكلية & $|\xi T|$ & 1Ero & \multicolumn{2}{|c|}{ السنة } \\
\hline$\% r 1$ & roq & $r+1$ & حكومية & \multirow{3}{*}{ علد الكليات } \\
\hline$\% r$ & $r q$ & ir & أهلية & \\
\hline$\% r \wedge$ & § & TIE & إجمالى & \\
\hline
\end{tabular}

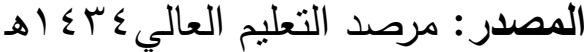

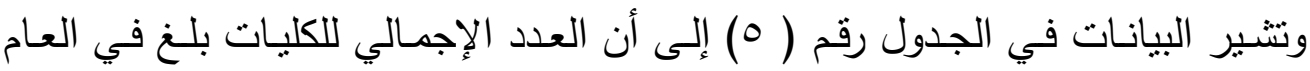

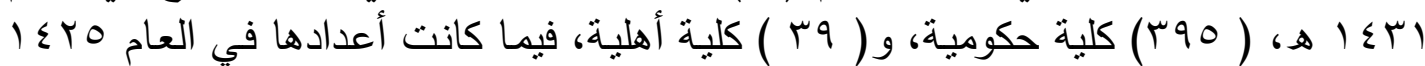

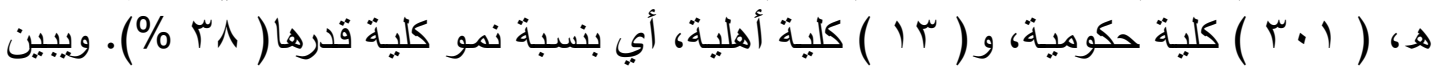

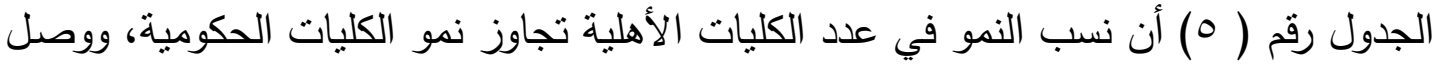

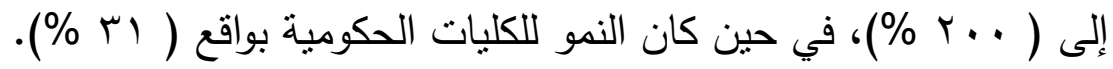

rـ الجامعات أو الكليات التي تمنح درجة الماجستير:

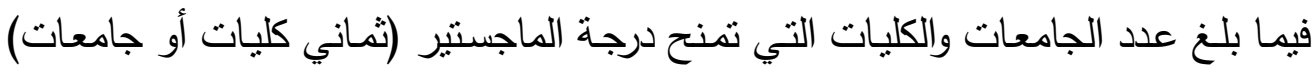

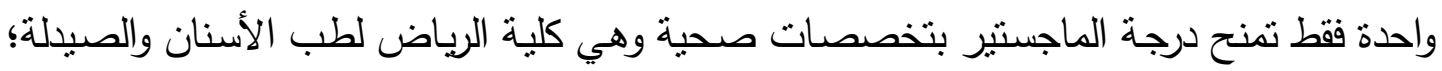

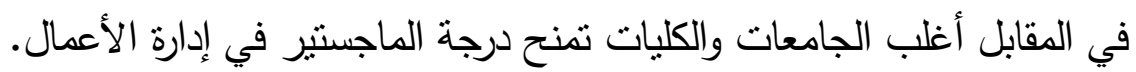

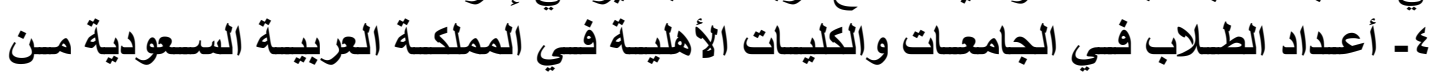


يوضح الشكل رقم ( ) أعداد الطلاب في الجامعات والكليات الأهلية بالمملكة العربية

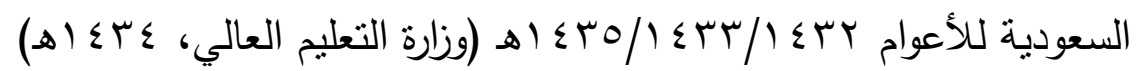

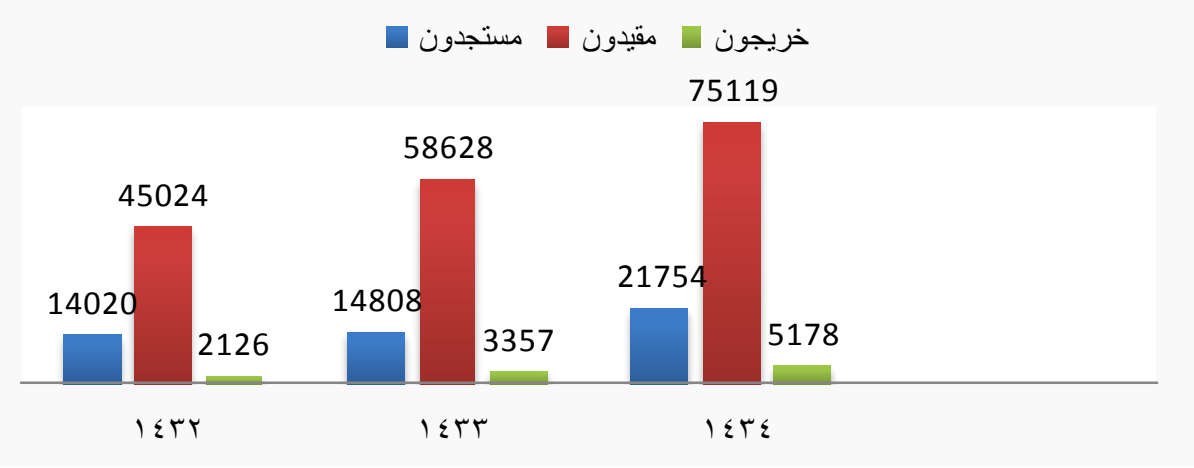

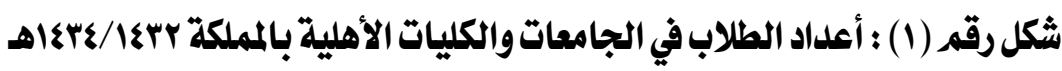

نستخلص ممـا سبق أن المملكة شهدت نمـًا منزايدًا للقطاع الخـاص اكتسب معـه قدرات

أهلته لأن تتيط بـه الدولة مسؤولية كبرى في تحقيق أهداف التتمية المرتبطة بضمان الاستمرار في معدلات النمو الاقتصادي، ورفع الكفاءة الداخلية للتعليم وإتاحة فرص العمل للمواطنين. سادسًا: من المشكلات الاقتصادية التي قد تشاهم خصخصة التعليم العالي في حلها:

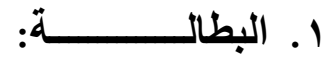

العمل على زيادة فرص العمل والتشغيل الأمثل للقوى الوطنية العاملة من خلال وضـع البرامج والأنظمة المالائمة والحوافز للقطاع الخاص لتوظيف السعوديين، وتعزيز القوى العاملة الوطنية وزيادة معدلات السعودة، وتوفير فرص تأهيل وتدريب العمالة الوطنية على رأس العمل هذا وتعد نسبة البطالة بين السعوديين في ازدياد فقد بلغت نسبة البطالة في عام ر م. . بم

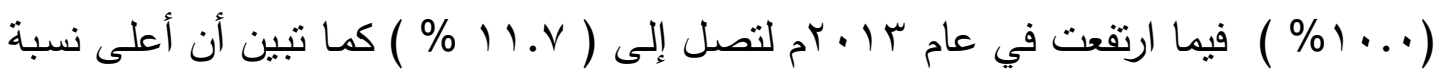

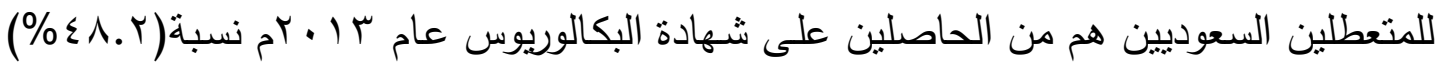

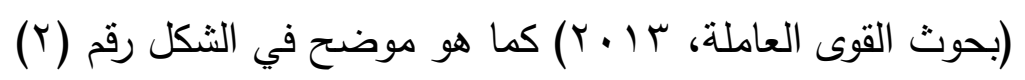




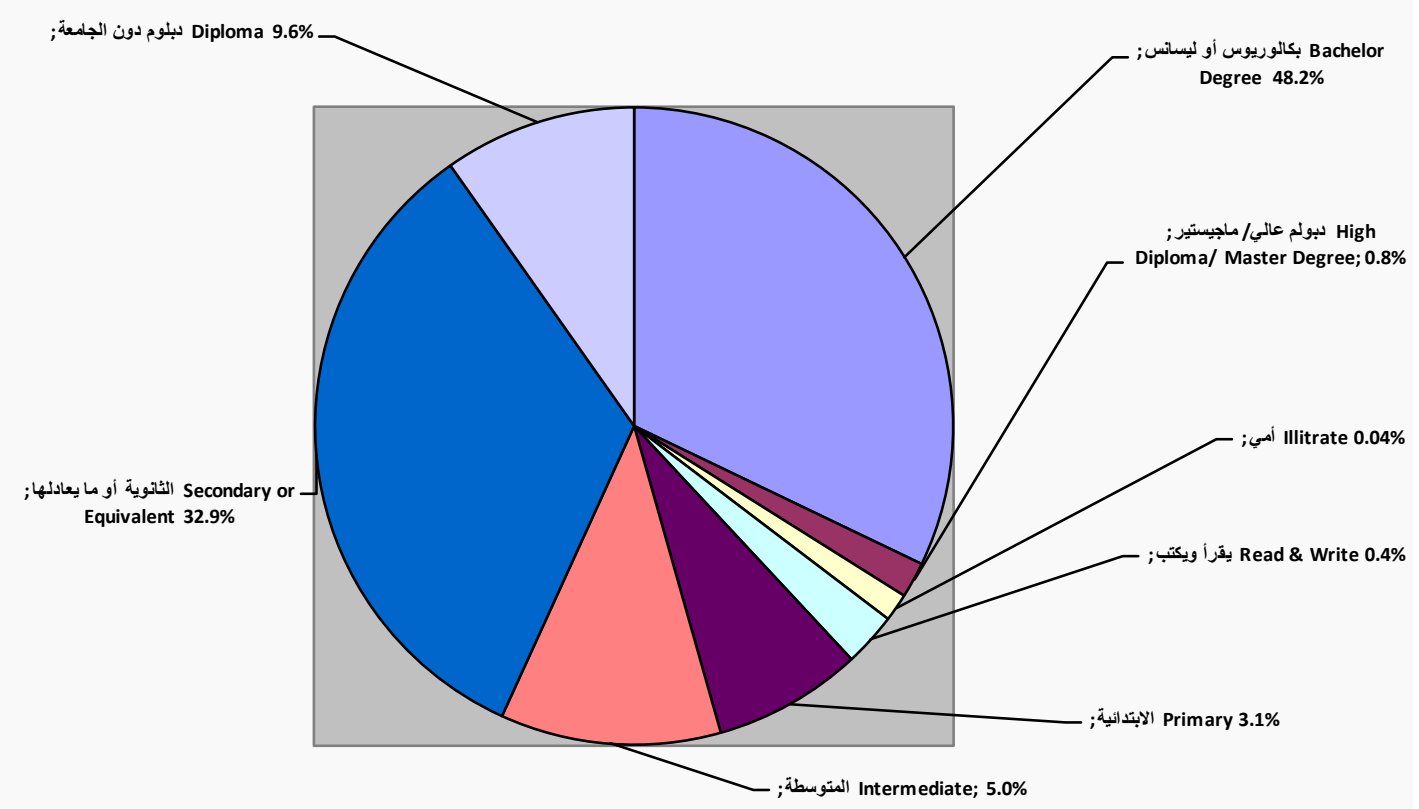

شكل رقم (r) :التوزيع النسبي للمتعطلين السموديين (0اسنة فأكثر ) حسب الحالة التعليمية

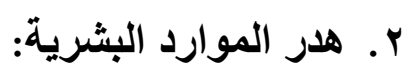

إن هدر الموارد البشرية السعودية الناتج عن عدم العدالة في توزيع القوى العاملة بين

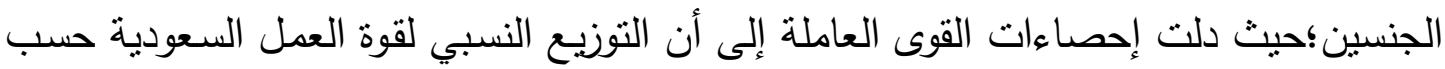

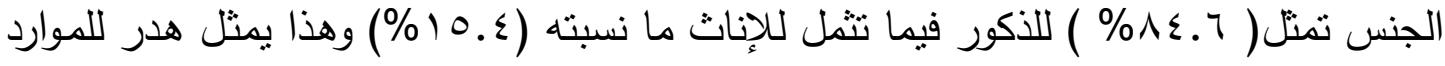
البشرية ( بحوث القوى العاملة، ب ا ـ ץ)كما هو موضح في الثكل رقم (ب، ع)

\section{Employed المشتظلون}

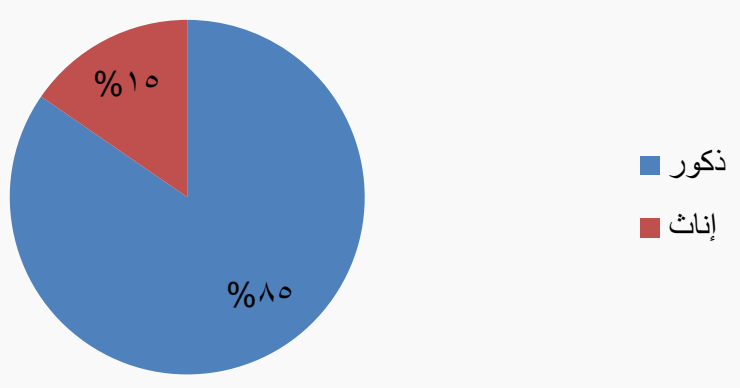




\section{شكل رقم (ץ) :التوزيع النسبي لقوة العمل السعودية (10 سنة فأكثر) حسب الجنس}

Unemployed المتعطلون

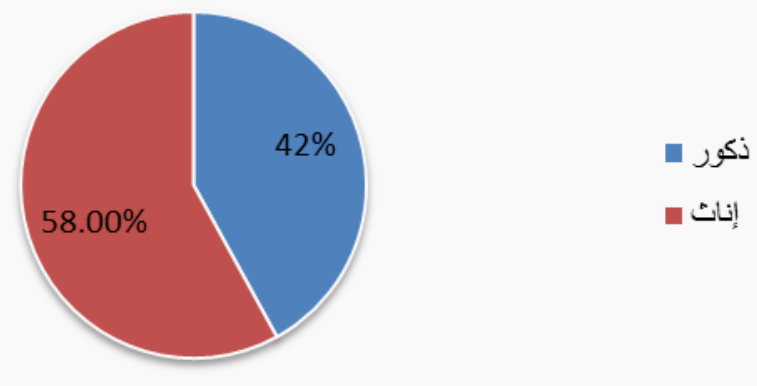

شكل رقم (؟) :التوزيع النسبي لقوة العمل السعودية (10 سنة فأكثر ) حسب الجنس

r. توفير التفقات التعليمية المصروفة في الخارج: إن خصخصة التعليم العالي في المملكة سيوفر بالتأكيد النفقات التعليمية المصروفة التهات بالخارج نتيجة الابتعاث للخارج لدراسة التخصصات المطلوبة والتي جاءت التخصصات الإدارية والهندسية والطبية على رأسها. حيث وجدت الباحثانة من خلال تحليلها لإحصائية أعدتها وزارة

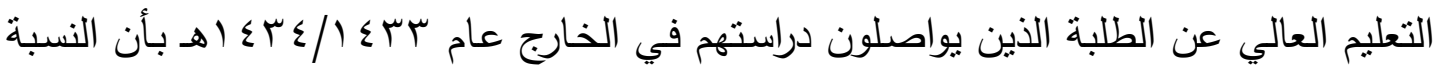
الأعلى جاءت لصالح العلوم الإدارية ثم الطبية ثم الهندية، كما وضحتها الباحثانة من خلال الرسم البياني التالي في الثكل رقم (0):

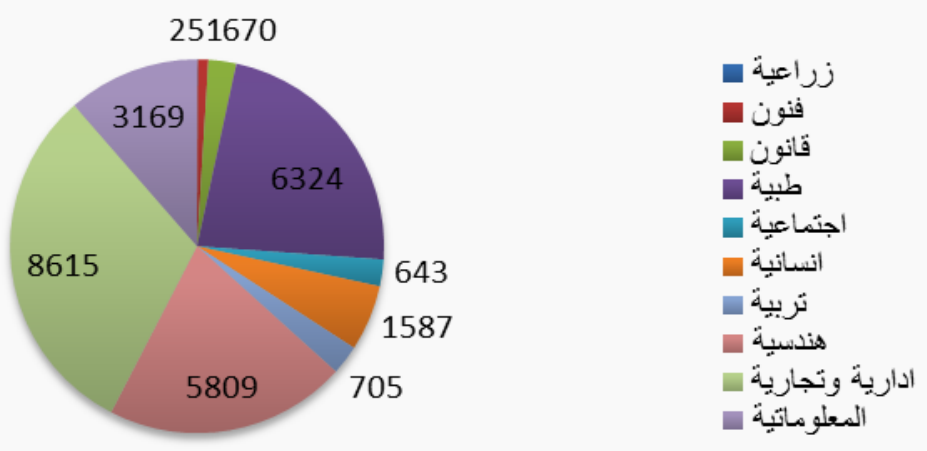

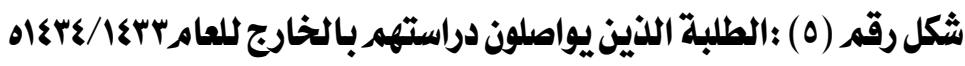

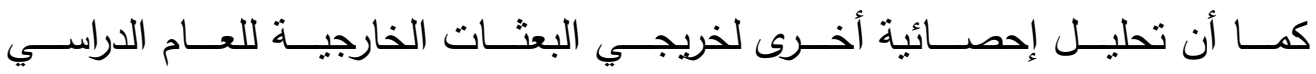

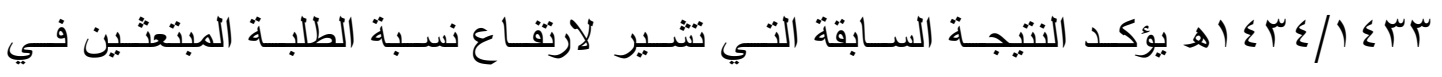
التخصصـات الإدارية والطبية والهندسية والتي وضحتها الباحثانة من خلال الرسم البياني في لإني

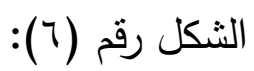




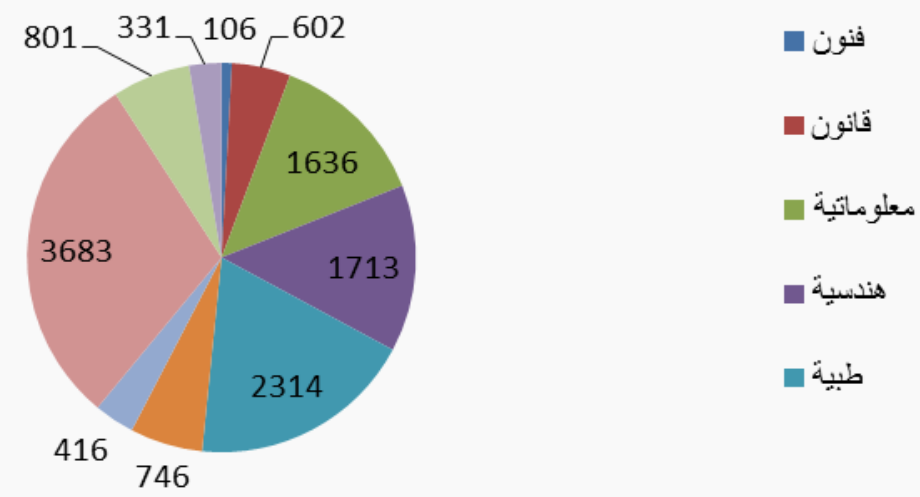

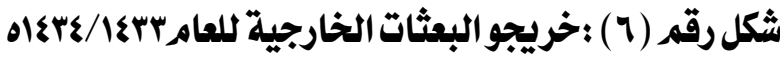

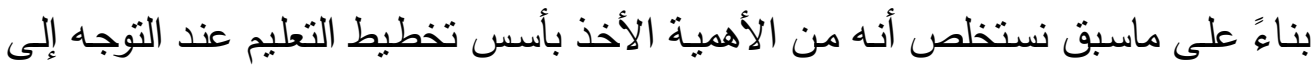

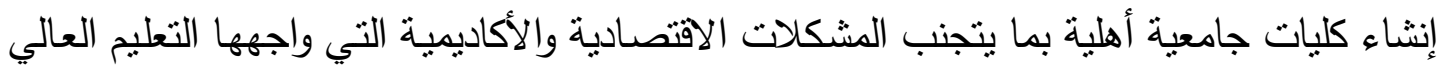

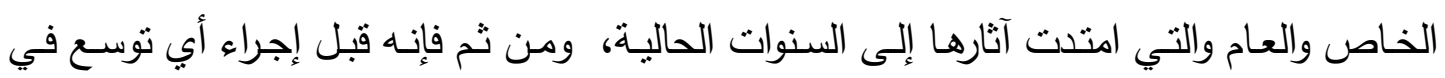
التعليم الجامعي عن طريق التعليم الخاص فإنه يجب التعرف بشكل دقيق على الاحتياجات المرتقبة

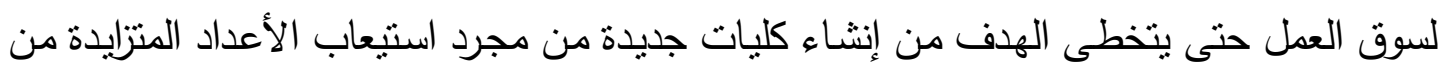

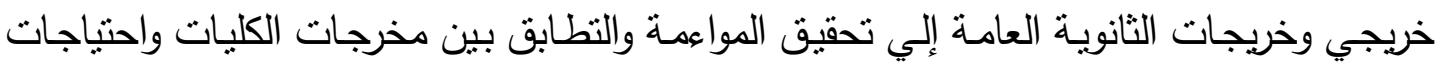
سوق العمل، مع ضرورة وضع خطط لاستقطاب هؤلاء الخريجين.

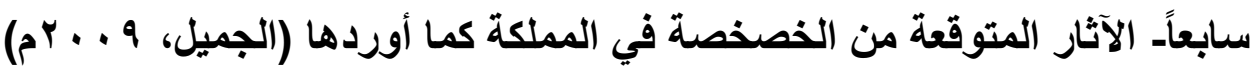

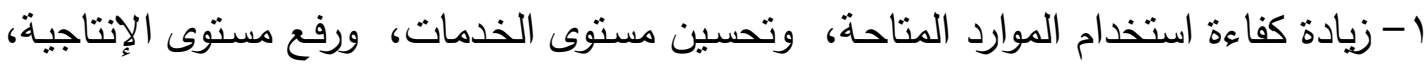

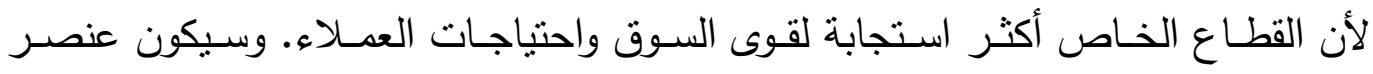
المنافسة هو الدافع الرئيس لتحسين إنتاجيتها وخدماتها وتخفيض تكلفتها.

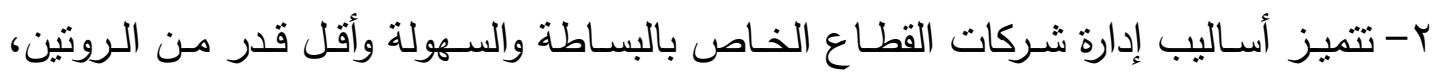
فضلاً عن سرعة اتخاذ القرارات بما يحقق أهدافها بعيداً عن الجمود والبيروقراطية.

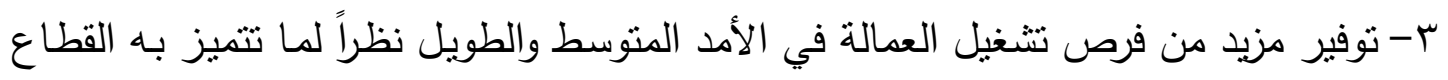

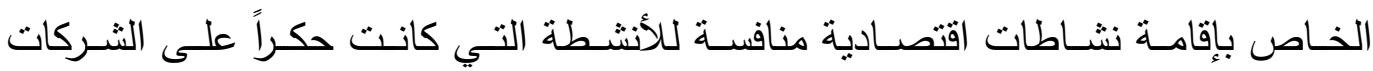
والمؤسسات العامة، وبالتالي إضافة فرص عمل جديدة.

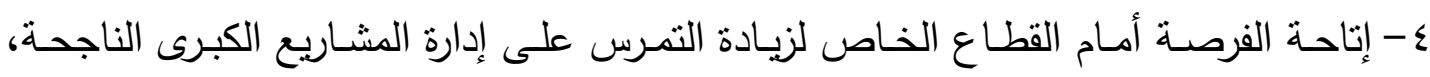

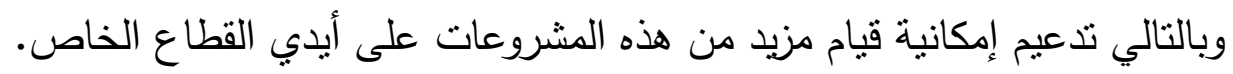

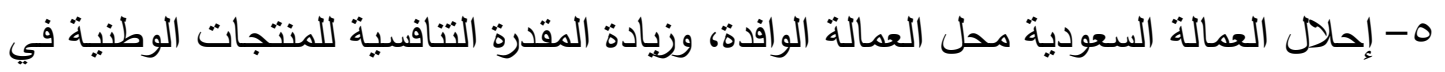
مواجهة المنتجات الأجنبية في الأسواق المحلية. 
ثامناً. نظرة تقييمية للتعليم العالي الخاص بالمملكة العربية السعودية:

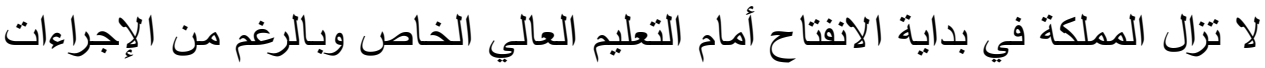

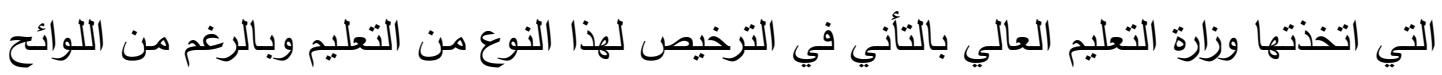

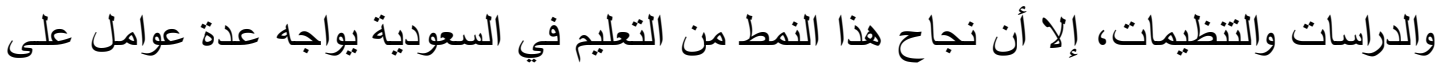

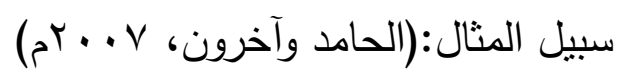

• وعي المواطن بأن التعليم العالي الخاص ينبغي أني أن يكون مجالاً للتميز ولا للتراخي والربح

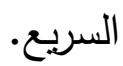

هناك حاجـة ماسـة إلى تعـاون الجامعـات الحكوميـة مـع مؤسسـات التعليم العـالي الخـاص

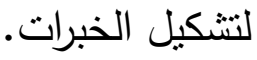

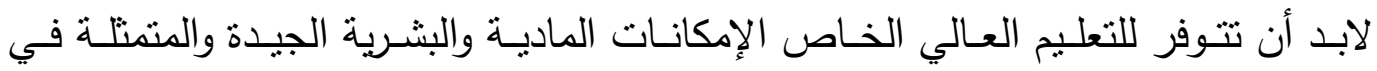

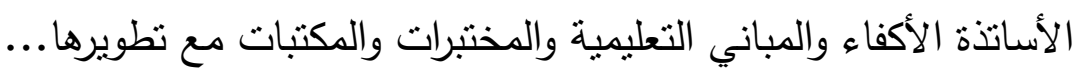
من الضروري أن ترتبط التخصصات باحتياجات سوق العمل حتى تكون متكاملة مع التعليم العالي الحكومي.

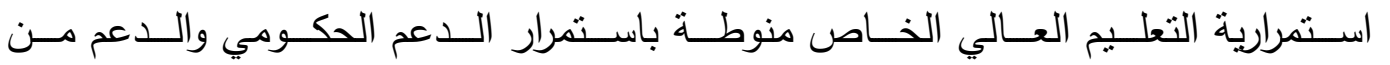

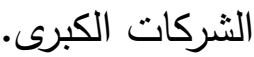
لابـد مـن استمرارية وزارة التعليم العـالي في الإتــراف والتقويم ومنـح الاعتهـاد الأكاديمي وسحب التزاخيص في حال المخالفة للثروط.

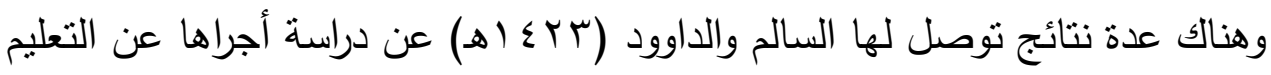

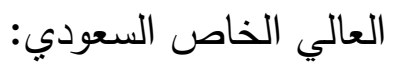

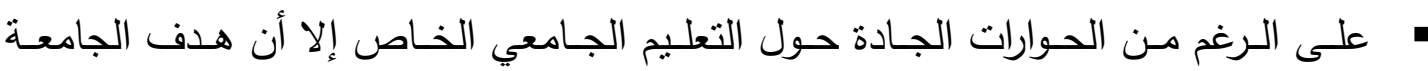

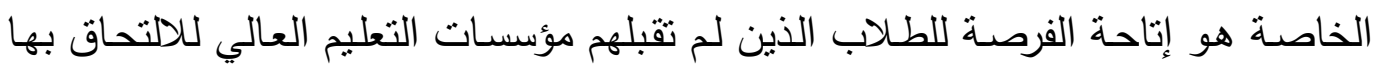

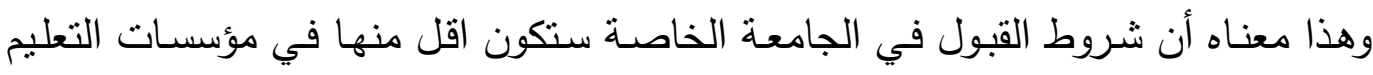

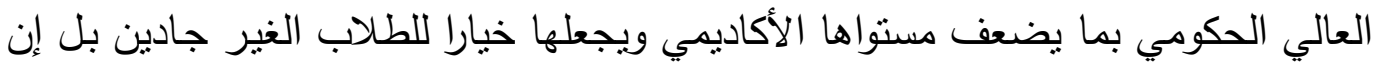

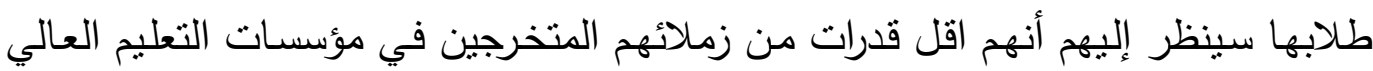
وسيصعب حصولهم على وظائف مناسبة.

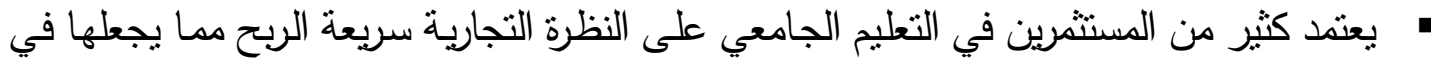

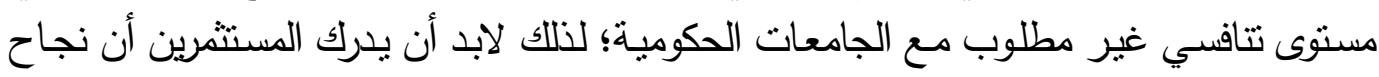

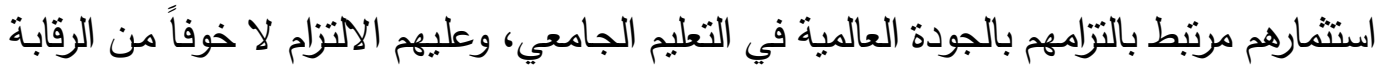

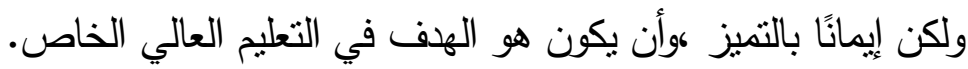


التوسع في استحداث أنماط غير تقلبدية لتوفير التعليم الجامعي على أن تتنوع وفقًا لطبيعة

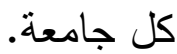

• أن الضعف الذي يعترض شركات ومؤسسات القطاع الخاص، لا يرجع إلى ضعف الحوافز

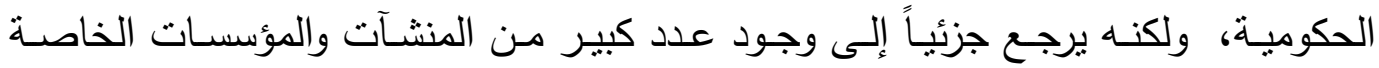

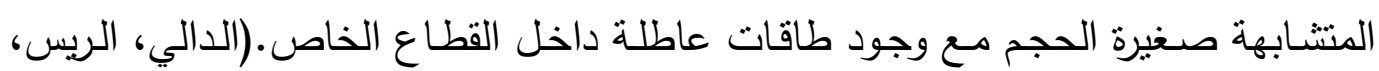

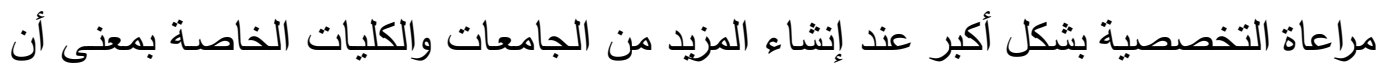

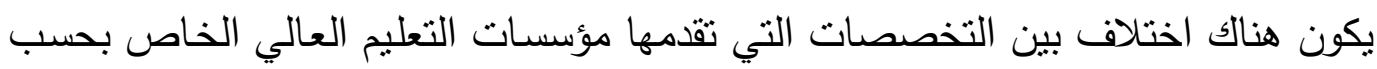

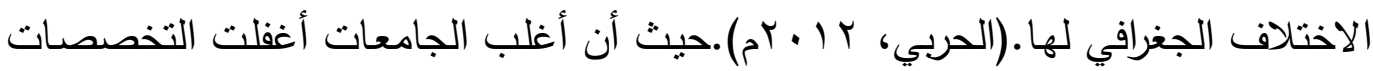

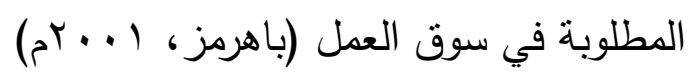

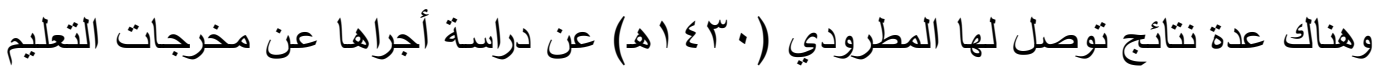

$$
\text { العالي (الحكومي، الخاص) السعودي: }
$$

- - وجود عائق الخبرات العملية للمنقدمين على الوظائف من مخرجات التعليم العالي والذي لابد من إعادة النظر فيها ومعالجتها من قبل القطاع الخاص.

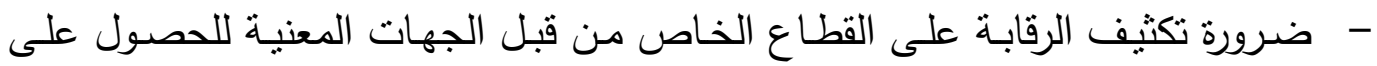
نتائج ملموسة بخصوص نسب مساهمة القطاع في توظيف السعوديين.

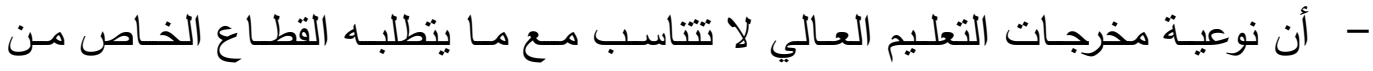
تخصصات ومهارات وغير ذلك. - وهناك عدة نتائج توصل لهات المنيع (د.ت) عن دراسـة أجراهـا عن تطوير مؤسسات

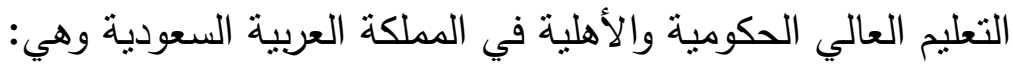

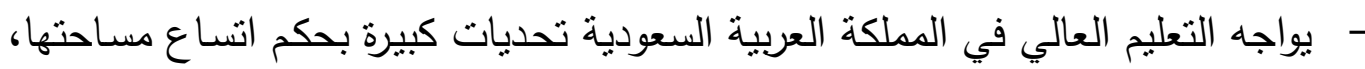

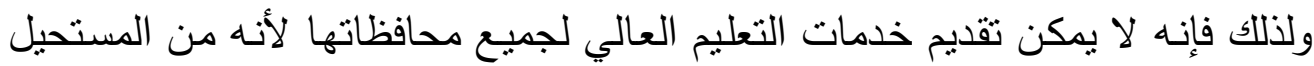
إنشاء مؤسسات للتعليم العالي في كل محافظة، ولكن باستخدام التعليم عن بعد يمكن

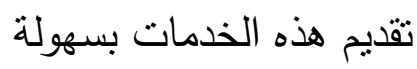

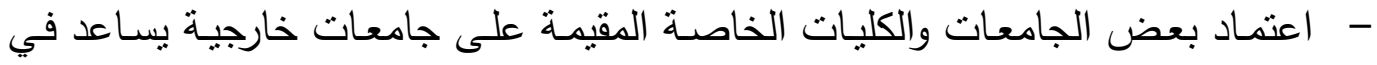
الاعتراف الأكاديمي وتطوير الجودة والنوعية في البرامج الأكاديمية والتدريسية ولكنها

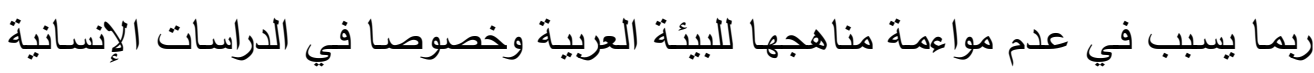
والتزبوية التي يجب أن تنبع من البيئة العربية.

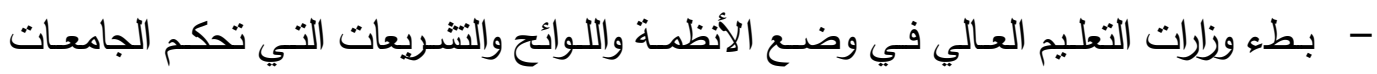
YOV 
والكليات الخاصة كما أن بعض هذه الوزارات تميل إلى إيجاد شروط يصعب تتفيذها حتى في

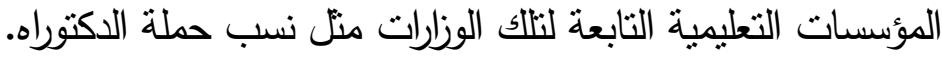

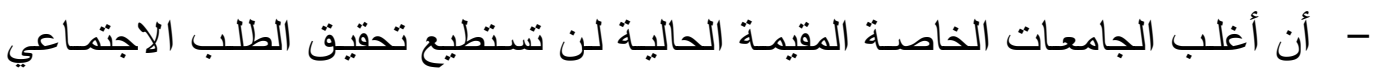

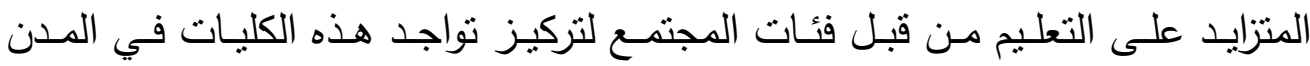

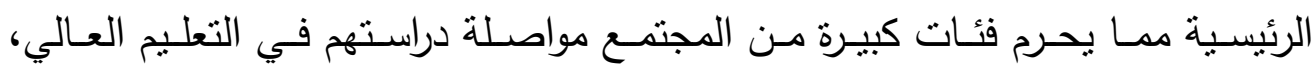

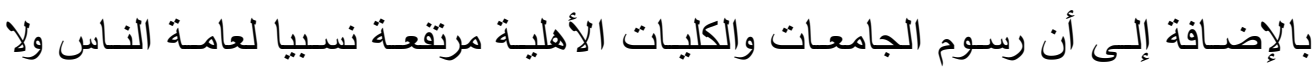

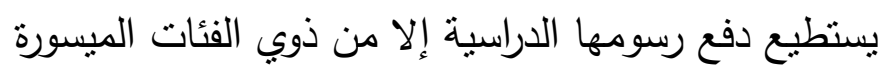

عدم تفعيل دور الثراكة بين التعليم العالي الخاص والحكومي بحيث يتم الاستفادة الفعلية

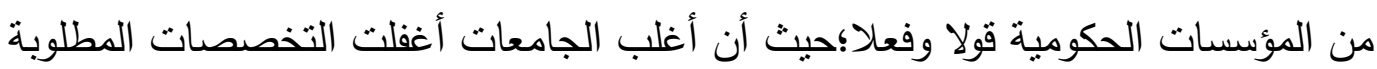

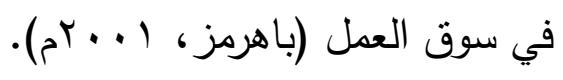

نستخلص مما سبق أن إفساح المجال أمام القطاع الخاص للمشاركة في ملكية وإدارة

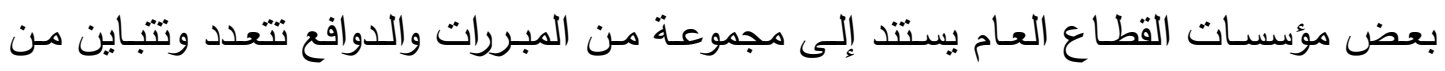

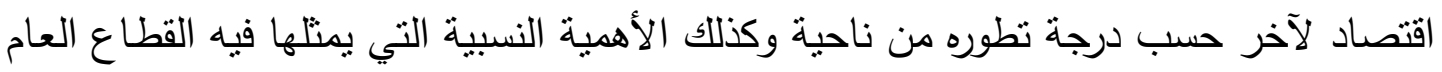

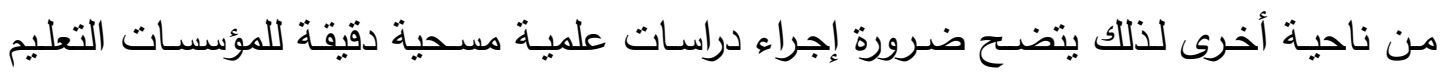
العالي الخاص لمعرفة سلبياتها وإيجابياتها ومساهمنها في توطين الوظائف الأكاديمية والمهنية

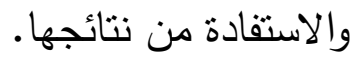

\section{الفصـل الرابـــع \\ إجــــــر اءات الدر اســـــة}

$$
\text { ا - منهج البحث: }
$$

من خلال طبيعة البحث والأهداف التي تسعى لتحقيقها تم استخدام المنهج الوصفي

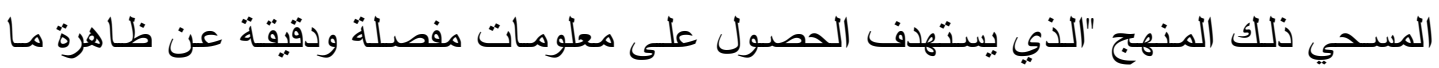

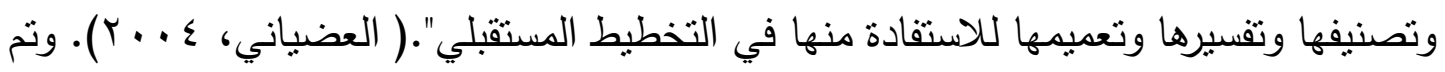

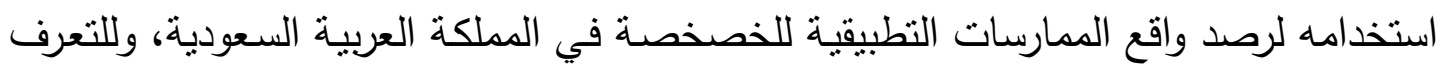

على الايجابيات، والسلبيات ، ووضع الإجراءات المقترح تطبيقها.

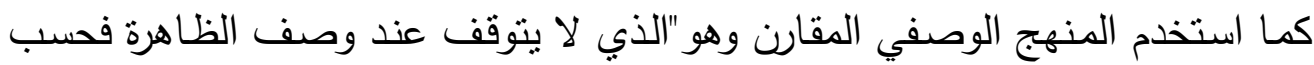

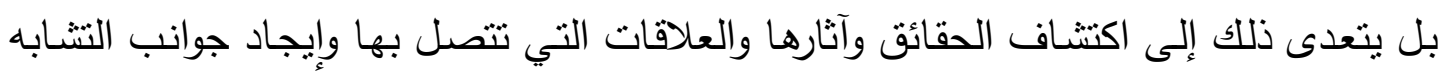

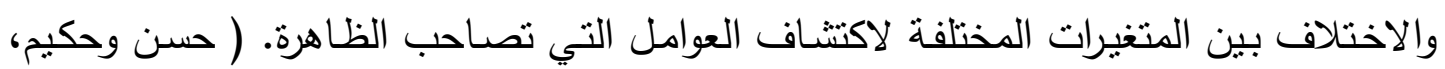


• • • (Y). وأستخدم لإبـراز الفروق بين نتائج أفراد العينـة في متغيرات الدراسـة (نوع الجامعة) لتقسيرها مجتمع البحث:

يتمثل مجتمع البحث في كلاً من: كلية الاقتصاد والإدارة في جامعة الملك عبد العزيز

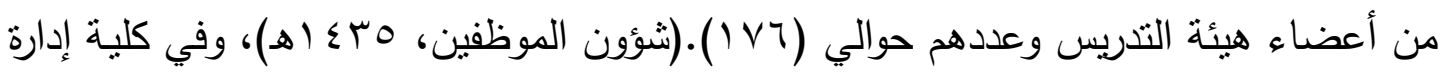

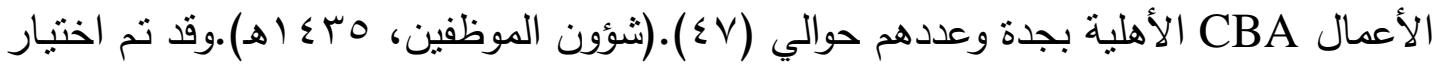

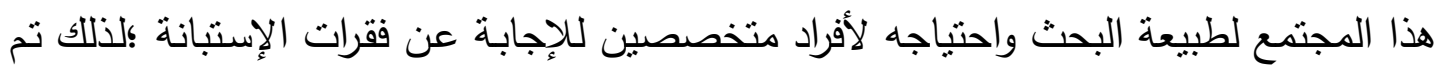

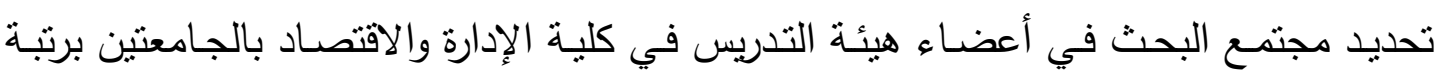
(أستاذ، أستاذ مشارك، أستاذ مساعد).

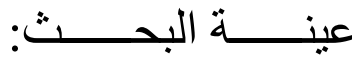

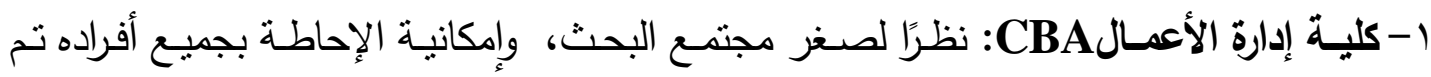

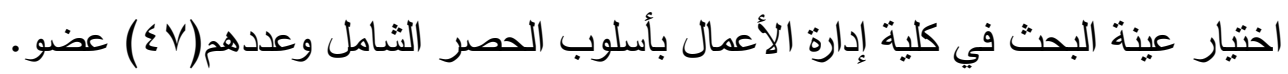

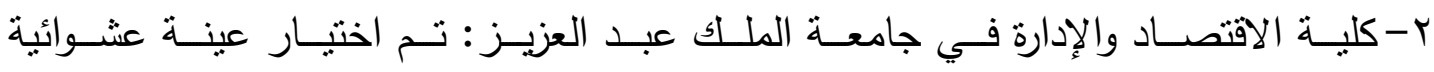

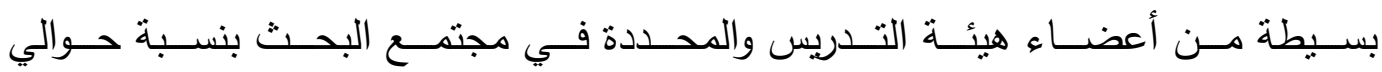

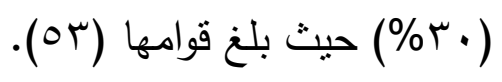

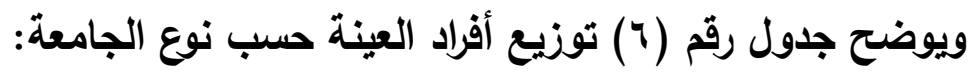

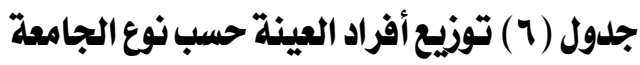

\begin{tabular}{|c|c|c|}
\hline النسبة المئوية \% & العدد & جهة العمل \\
\hline 53.0 & or & جامعة الملك عبد العزيز بجلدة \\
\hline 47.0 & sv & كلية إدارة الأعمال الأهلية بجدة \\
\hline$\% 1 \ldots$. & $1 .$. & المجموع \\
\hline
\end{tabular}

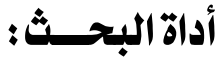

بعد أن تم الاطلاع على الأدب التربوي، والدراسات السابقة المتعلقة بموضوع البحث ووفقًا لتعريفات البحث الإجرائية، نم بناء أداة البحث (الاستبانة) وفق الخطوات التالية:

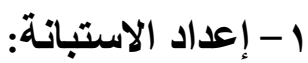
- تكونت الاستبانة من جزأين رئيسين هما: 
عبارة عن بيانات أولية عن عينة البحث تتمثل في: (نوع الجامعة).

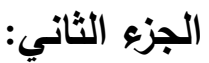

تتاول عبارات للخصخصة في التعليم العالي في المملكة العربية السعودية والذي أحتوى

$$
\text { على أربعة (ع) محاور انتملت على (OV) عبارة نم توزيعها كالثالي: }
$$

المحور الأول: واقع الممارسات التطبيقية للخصخصة في التعليم العالي ويتكون من (V) فقرات.

المحور الثاني: إيجابيات خصخصة التعليم العالي بالمملكة العربية السعودية ويتكون من (9 (1)

فقرة.

المحور الثالث: السلبيات التي قد تتتج عن خصخصة التعليم العالي ويتكون من (r (I) فقرة.

المحور الرابع: الإجراءات المقترح تطبيقها للخصخصـة في مؤسسات التعليم

$$
\text { العالي ويتكون من(9 (1) فقرة. }
$$

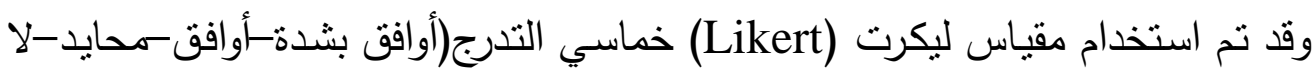

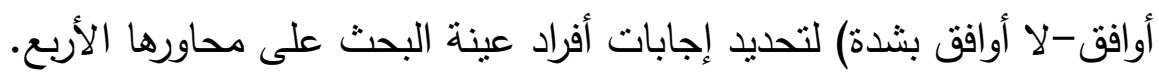

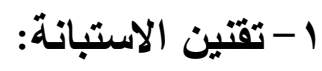

للتأكد من صدق الاستبانة تم استخدام الطرق النالية:

$$
\text { أ- أ- صدق أداة البحث: }
$$

اعتمد الباحثان للتحقق من صدق الأداة على طريقتين الأولى وتسمى الصدق الظاهري

(Face validity)، التي تعتمد على عرض الأداة على مجموعة من المتخصصين الخبراء في المجال، أما الثانية وتسمى الاتساق الداخلي (Internal Consistency) وتقوم على حساب معامل الارتباط بين كل محور من محاور الأداة، وفيما يلي الخطوات التي اتبعتها الباحثانة للتحقق من صدق الأداة طبقا لكل طريقة من الطريقتين: أ- (1) الصدق الظاهري (صدق المحكمين): بعد الانتهاء من بنـاء الاستبانة، تم عرضهها في صورتها الأولية على مجموعة من

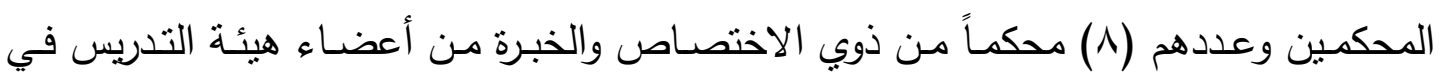


الجامعات المختلفة ملحق رقم (...)، وذللك بهدف إصدار الحكم لمدى وضوح صياغة العبارات وانتمائها للأُعد الذي وردت فيه، واقتراح ما يرونه مناسباً من تعديل أو حذف أو إضافة عبارات أخرى أو غير ما ورد مما يرونه مناسباً.

فأثنار \% \% إلى وجود بعض الفقرات المركبة وعددها (ع) والتي تحتاج إعادة صياغة حتى تكون قابلة للقياس بسهولة، وقد تم أخذ جميع الملاحظات بعين الاعتبار كما اتفق عليه

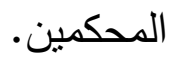

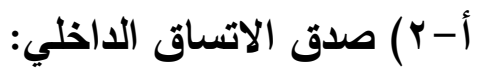
من أجل التأكد من صدق الاستبانة الداخلي، فقد تم توزيع الاستبانة على عدد (·r) عضو هيئة تدريس من مجتمع البحث من غير أفراد العينة، ومن ثم حساب صدق الاتساق الداخلي للاستبانة عن طريق حساب معاملات ارتباط كل فقرة مع الدرجة الكلية للدحور الذي تهري تتنمي إليه وكانت النتائج كالتالي: 
جلدول رقم (v) معامل ارتباط كل فقرة مع درجة المحور الذي تنتمي إليه

\begin{tabular}{|c|c|c|c|c|c|c|c|}
\hline الارتباط معامل & رقثم & معامل الارتباط & رقم الفقرة & 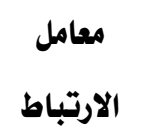 & رقم الفقرة & الارتباط معامل & رقمر \\
\hline$* * 0.619$ & $\{7$ & $* 0.407$ & ri & $* * 0.756$ & 17 & $* * 0.885$ & 1 \\
\hline$* * 0.682$ & sv & $* 0.806$ & $r r$ & $* * 0.742$ & iv & $* * 0.776$ & $r$ \\
\hline$* * 0.632$ & $\{\wedge$ & $* * 0.681$ & rr & $* 0.500$ & 11 & $* * 0.813$ & $r$ \\
\hline$* 0.573$ & 29 & $* * 0.793$ & $r \xi$ & $* 0.793$ & 19 & $* * 0.652$ & $\xi$ \\
\hline$* * 0.843$ & 0. & $* 0.693$ & ro & $* 0.789$ & r. & $* * 0.458$ & 0 \\
\hline$* * 0.852$ & 01 & $* 0.655$ & $r q$ & $* 0.725$ & $r$ & $* 0.839$ & 7 \\
\hline$* * 0.824$ & or & $* * 0.603$ & $r v$ & $* 0.783$ & $r r$ & $* * 0.804$ & $r$ \\
\hline$* * 0.763$ & or & $* 0.779$ & $r \Lambda$ & $* 0.846$ & rr & $* * 0.756$ & $\wedge$ \\
\hline$* * 0.891$ & oq & $* 0.876$ & $r q$ & $* * 0.726$ & Yq & $* * 0.804$ & 9 \\
\hline$* 0.769$ & 00 & $* 0.729$ & $\xi$ & $* 0.784$ & ro & $* 0.743$ & 1. \\
\hline$* * 0.429$ & 07 & $* 0.562$ & \&1 & $* * 0.569$ & rq & $* * 0.654$ & 11 \\
\hline$* 0.619$ & or & $* * 0.350$ & $\varepsilon r$ & $* * 0.573$ & $r V$ & $* * 0.382$ & ir \\
\hline & & $* 0.495$ & $\xi r$ & $* 0.486$ & $r \Lambda$ & $* * 0.689$ & ir \\
\hline & & $* 0.394$ & $\llbracket$ & $* * 0.382$ & rq & $* * 0.582$ & $1 \xi$ \\
\hline & & $* 0.619$ & so & $* * 0.824$ & r. & $* * 0.789$ & 10 \\
\hline
\end{tabular}

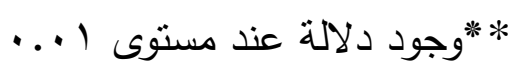

يلاحظ من الجدول (V) أن جميع معاملات الارتباطات لجميع الفقرات موجبة الإشـارة ودالة إحصائياً عند مستوى (1 . . ) مما يشير إلى تمتع الفقرات جميعها بصدق اتساق داخلي جيد مع محاورها الممثلة لها.

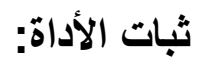
للتحقق من ثبات الاستبانة، فقد تم توزيع الاستبانة على عدد (·r) عضو هيئة تدريس من مجتمع البحث من غير أفراد العينة، ومن ثم تم حساب معامل الثبات باستخدام معادلة ألفا كرونباخ (Cronbach Albha). 
ويوضح الجدول التالي معاملات الثبات الناتجة باستخدام هذه المعادلة:

جدول رقه ( 1) معاملات ثبات أداة البحث

\begin{tabular}{|c|c|c|}
\hline معامل الفاكرونباخ & علد الفقرات & المحســـــــــور \\
\hline$\cdot$. ATE & $\checkmark$ & واقع الممارسات التطبيقية للخصخصة في التعليم العالي \\
\hline .9 . $9 \mathrm{r}$ & 19 & إيجابيات خصخصة التعليم العالي بالمملكة العربية السعودية \\
\hline$\cdot$ Arr & ir & السلبيات التي قد تنتج عن خصخصة التعليه العالي \\
\hline$\cdot$. Arq & 19 & الإجراءات المقترحة عند تطبيق الخصخصة في مؤسسات التعليه العالي \\
\hline •.974 & or & الاستبانة ككل \\
\hline
\end{tabular}

يتضـح من الجدول (^) إن قيم معاملات الثبات جميعها قيم عالية حيث تراوحت قيم

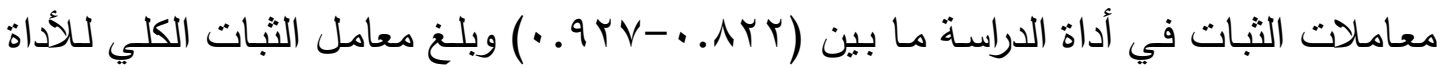

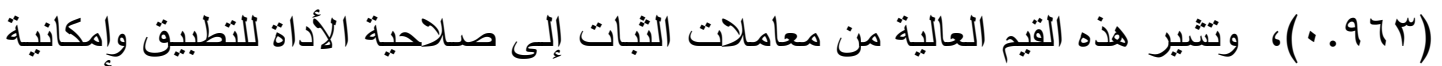
الاعتماد على نتائجها والوثوق بها.

\section{الفصـــــل الخامــــس \\ مناقشة وتحليل نتائج الدر اسة}

عرض نتائج الدارسة ومناقثنتها:

يتتاول هذا الفصل عرض نتائج الدارسة الميدانية ومناقشتها من خلال عرض إجابات

أفراد الدراسة على عبارات الاستبانة وذللك بالإجابة عن أسئلة الدراسة على النحو التالي: السـؤال الأول: مـا واقع الممارسـات التطبيقيـة للخصخصـة في مؤسسـات التعليم العـالي في المملكة العربية السعودية من وجهه نظر أعضاء هيئة التدريس في كلية الاقتصاد والإدارة في جامعة الملك عبد العزبز وكلية إدارة الأعمالCBA الأهلية بجدة ؟ للإجابـة على السـؤال الأول قـام الباحثنان بتخصـيص (V) فقرات لقيـاس واقـع الممارسـات التطبيقية للخصخصة في مؤسسات التعليم العالي في المملكة العربية السعودية من وجهه نظر أعضـاء هيئة التدريس في كليـة الاقتصـاد والإدارة في جامعـة الملك عبد العزبز وكليـة إدارة الأعمالCBA الأهلية بجدة، وفيما يلي عرض نتائج إجابات أفراد العينة على هذه الفقرات:

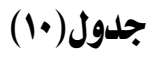


المتوسطات الحسابية والانحرافات المعيارية والتزتيب لفقراتواقع الممارسات التطبيقية للخصخصة في

مؤسسات التعليه العالي في المملكة العربية السعودية العباتية

\begin{tabular}{|c|c|c|c|c|c|c|c|}
\hline \multicolumn{3}{|c|}{ كلية إدارة الأعمالCBA الأهلية } & \multicolumn{3}{|c|}{ 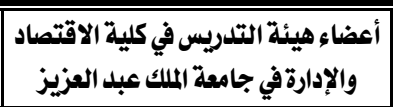 } & \multirow{2}{*}{ الفقــــــــــــات } & \multirow[b]{2}{*}{ هـ } \\
\hline الموافقة & | الترتيب & المتوسط & لدرجة & الترتيب & المتوسط & & \\
\hline محايل & 4 & 3.36 & أواقت & 3 & 3.40 & |تطبق الخصخصة الآن بشكل مرحلي & 1 \\
\hline محايل & 5 & 3.15 & 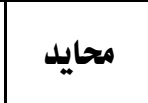 & 5 & 3.34 & | تحويل بعضاص الـبرامج في التعليه العـالي العـام إلى & 2 \\
\hline 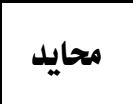 & 6 & 2.64 & 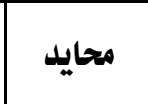 & 6 & 2.92 & | مع القطاع الخصخصة حاليًا على عقود صيانة وتشفيل & 3 \\
\hline أوافق & 3 & 3.40 & 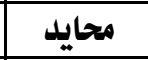 & 4 & 3.38 & هناك برامج تدار بأكملها من القطاع الخاص & 4 \\
\hline ل أوافق & 7 & 2.34 & 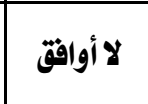 & 7 & 2.55 & 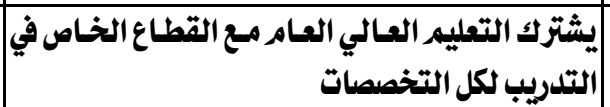 & 5 \\
\hline أوافق بشدة & 2 & 4.38 & أواقق & 2 & 4.15 & 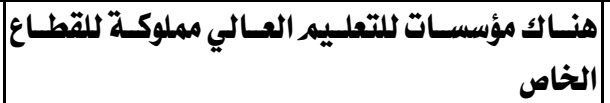 & 6 \\
\hline أوافق بشدة & 1 & 4.51 & أوافق بشدة & 1 & 4.30 & | الخاصـارك الدولـة في تمويل مؤسسات التعليه العالي| & 7 \\
\hline أواقت & & 3.40 & أواقق & & $r . \& r$ & الواقـــــــــــــل & \\
\hline
\end{tabular}

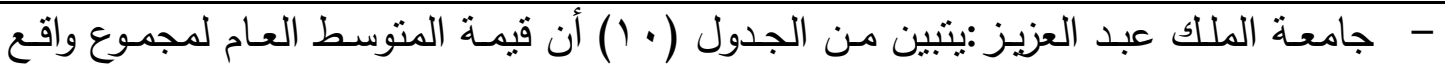

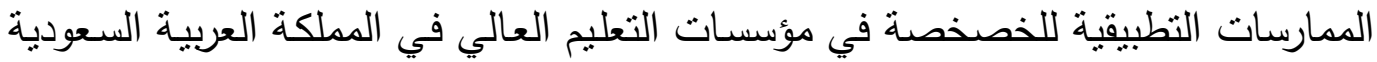

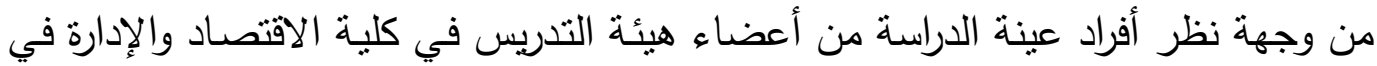

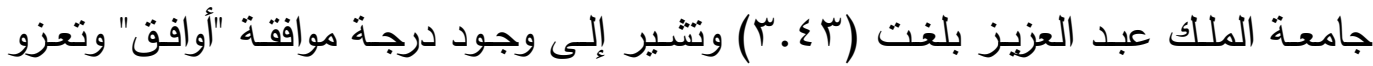

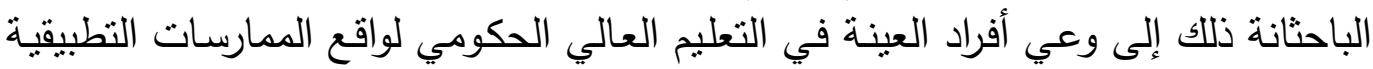

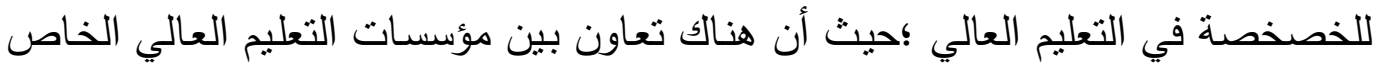

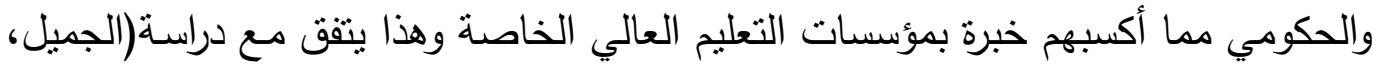
. 9

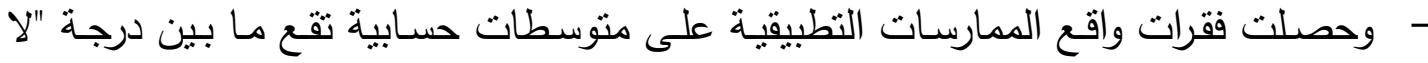

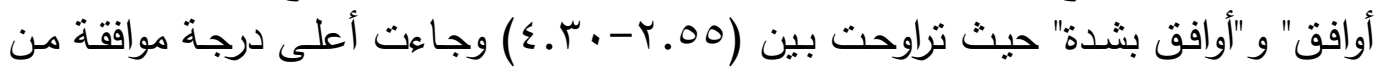

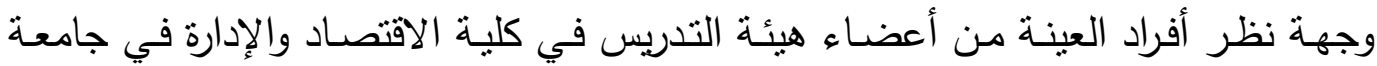

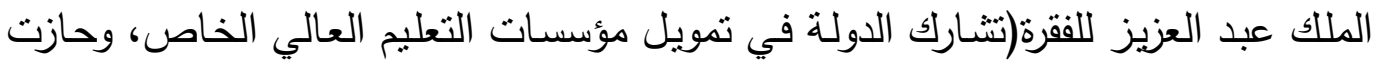

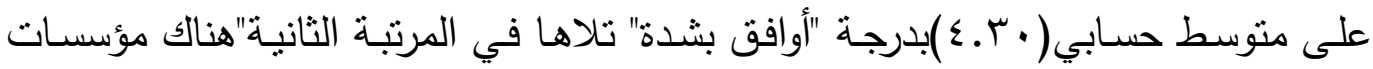

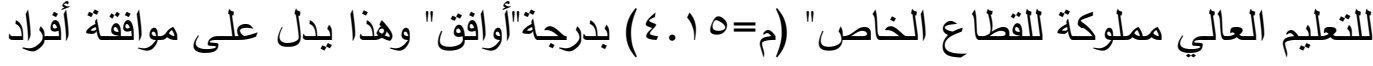

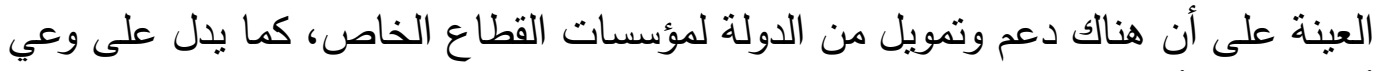

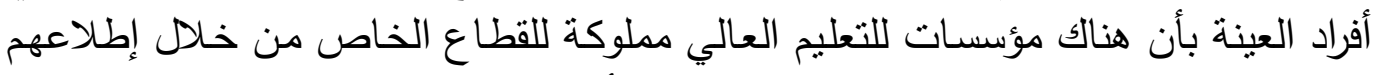

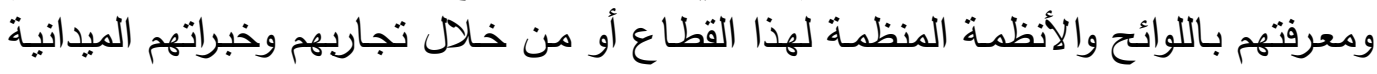




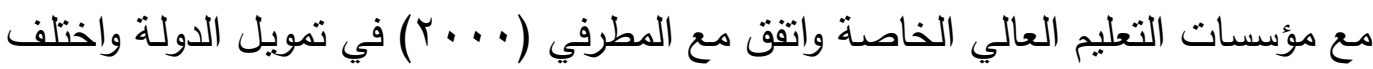

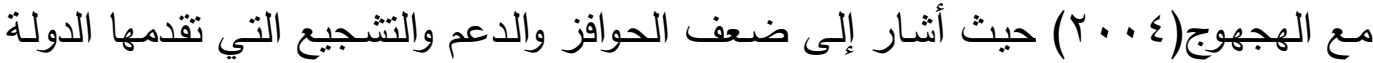

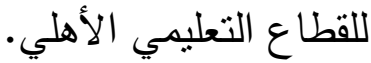
- وجاء في المرتبتين الأخيرتين كلا من الفقرتين "تقتصر الخصخصة حاليًا على عقود صيانة

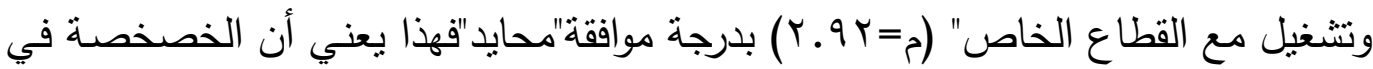

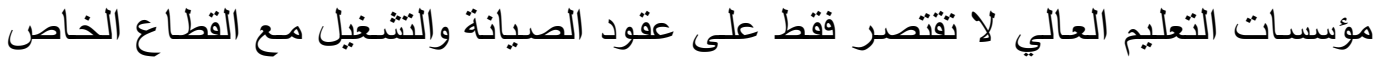

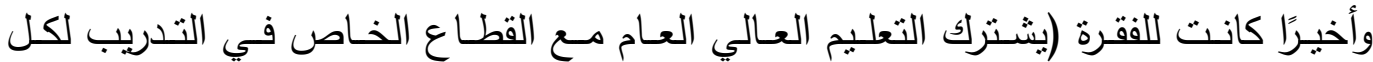

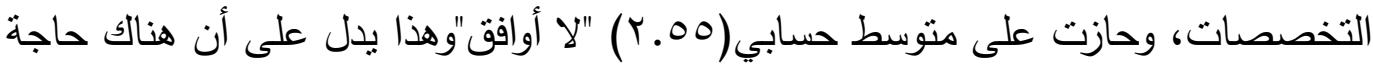
لمزيد من التعاون بين القطاعين العام والخاص لتكثيف التدريب.

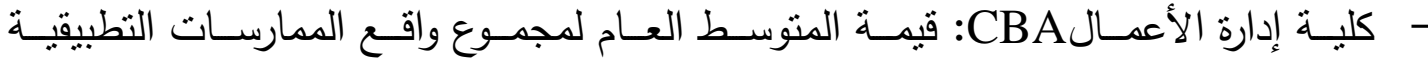

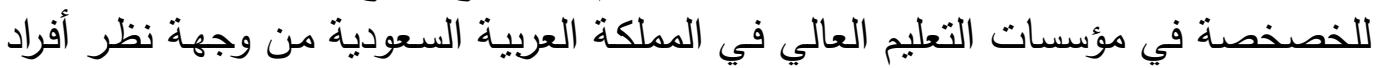

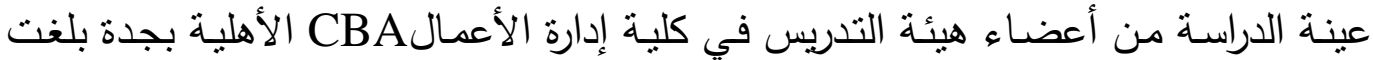

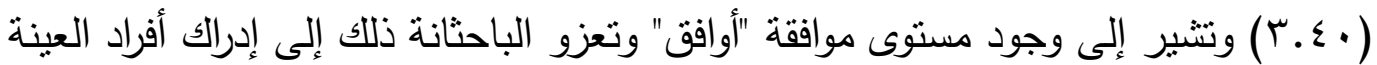

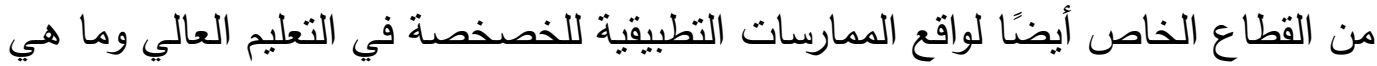

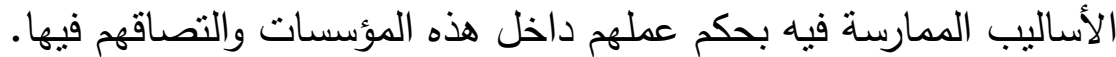

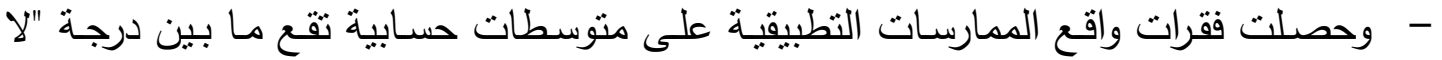

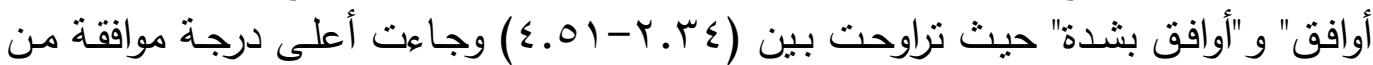

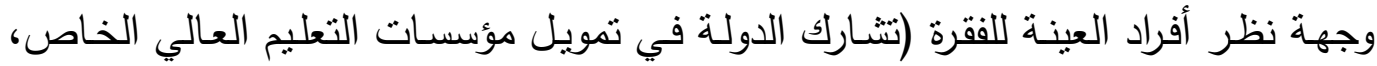

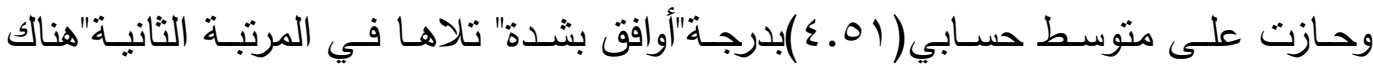

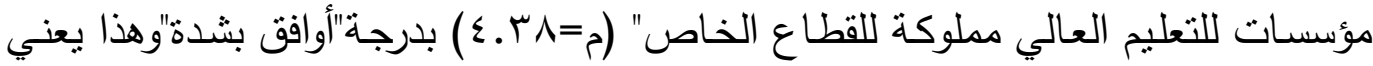

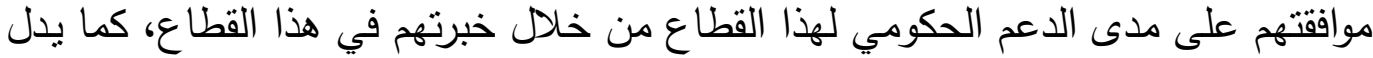

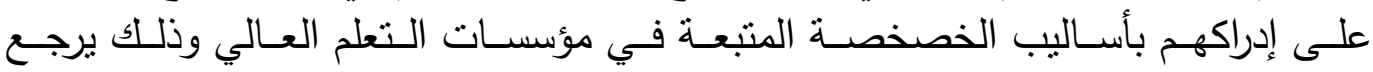
لمالامستهم والتصاقهم بهذا الواقع. - - وكان أقل درجة موافقة من وجهة نظر أفراد العينة من أعضاء هيئة التدريس في كلية إدارة

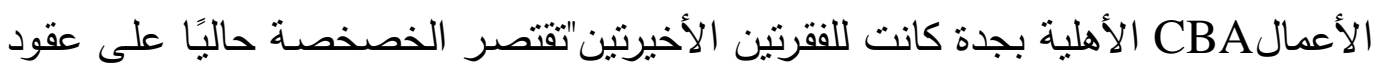

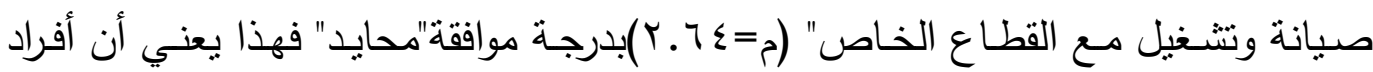

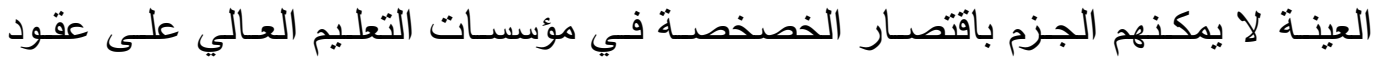

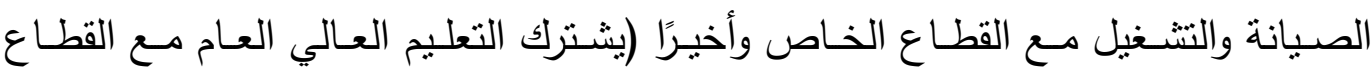

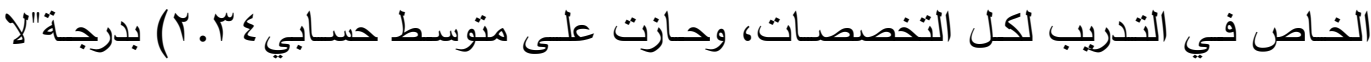
أوافق"ويدل ذلك على أن واقع التدريب المشترك بين العام والخاص لم يكن مفعلاً بكفاءة التهاء ويحتاج إلى مزيد من التدريب والتأهيل للطلبة واتفق ذلك مع دراسة (باهرمز ، ( . . ب). 
السؤال الثاني: ما الايجابيات التي تدعو للتوسع في الخصخصـة في مؤسسات التعليم العالي في المملكة العربية السعودية من وجهه نظر أعضاء هيئة التدريس في كلية الاقتصاد والإدارة

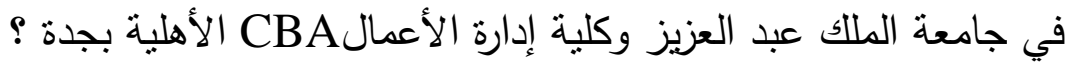

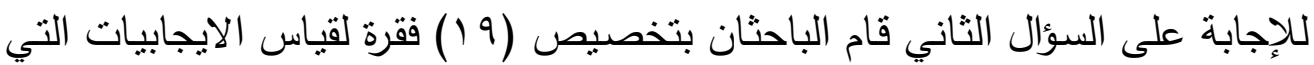

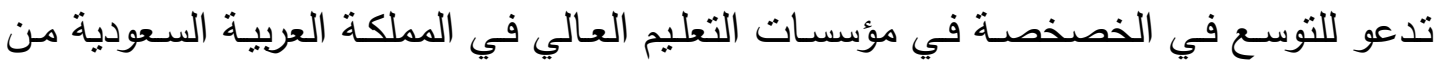
وجهه نظر أعضاء هيئة التدريس في كلية الاقتصاد والإدارة في جامعة الملك عبد العزيز وكلية

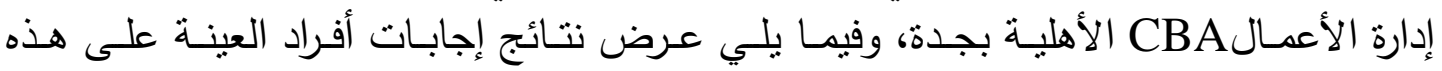
الفقرات:

جدول(II)

المتوسطات الحسابية والانحرافات المعيارية والترتيب لفقرات الإيجابيات التي تلعو للتوسع في الخصخصة في مؤسسات التعليه العالي في المملكة العربية السعودية

\begin{tabular}{|c|c|c|c|c|c|c|c|}
\hline \multicolumn{3}{|c|}{ كلية إدارة الأعمالCBA الأهلية } & \multicolumn{3}{|c|}{ أعضاء هيئة التدريس في كلية الاقتصاد } & \multirow[t]{2}{*}{ الفقــــــــــــات } & \multirow[t]{2}{*}{ هـ } \\
\hline | درجة الموافقة | & |الترتيب & |المتوسط & درجة المواققة & الترتيب & المتوسط & & \\
\hline | أواقق بشدة & 6 & 4.45 & أواقق & 4 & 4.08 & | تفطي تخصصات جليدة ومتنوعـة لا توجـد في & 1 \\
\hline | أواقق بشدة & 10 & 4.36 & أواقق & 5 & 4.08 & |متطلبات سوقة العمل فيـق الـبرامج وتكييفهـا حسبـ| & 2 \\
\hline | أوافق بشدة & 13 & 4.32 & أواقق & 6 & 4.06 & |تحقـق الشـراكة المجتمعيـة في إعـلـاد بـرامج & 3 \\
\hline | أوافق بشلة & 8 & 4.40 & أوافق & 2 & 4.15 & | تأفودي إلى إيجـاد روح التنــافس على المسـتوى & 4 \\
\hline | أواقق بشدة & 5 & 4.49 & أوافق & 15 & 3.81 & |تلتجارة العالية فواكبـة التطورات العالميـة لمنظمـة & 5 \\
\hline | أوافق بشلة & 2 & 4.53 & أواقق & 19 & 3.74 & |تمانًا فر فرة الاستثمار الوطني بالداخل الاكثر| & 6 \\
\hline أوافق & 16 & 4.17 & أوافق & 16 & 3.79 & |الاججنبي تسـاعد في الاسـتفادة مـن خـبرات الشـريك & 7 \\
\hline أواقق بشدة & 1 & 4.55 & أوافق & 12 & 3.87 & تخريج الكفاءات البشرية المؤهلة لسوق العمل & 8 \\
\hline | أواقق بشدة & 11 & 4.34 & أواقق & 14 & 3.81 & أكثر سرعة ومرونة في الإنجازبطريقة فاعلية & 9 \\
\hline | أواقق بشدة & 9 & 4.36 & 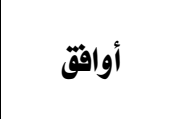 & 13 & 3.87 & | أفضل تسـاعد في اسـتثمار المـوارد البشـرية بشـكل & 10 \\
\hline | أواقق بشدة & 4 & 4.51 & أوافق بشلة & 1 & 4.21 & | التوسع في نشر التعليه العالي & 11 \\
\hline
\end{tabular}




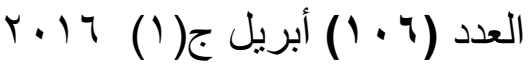

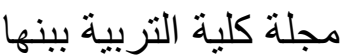

\begin{tabular}{|c|c|c|c|c|c|c|c|}
\hline \multicolumn{3}{|c|}{ كلية إدارة الأعمال CBAA الأهلية } & \multicolumn{3}{|c|}{ أعضاء هيئة التدريس في كلية الاقتصاد } & \multirow[t]{2}{*}{ 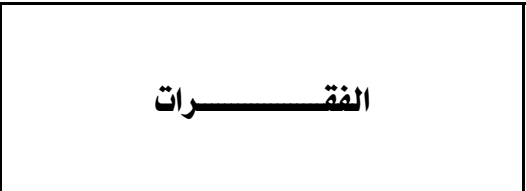 } & \multirow[t]{2}{*}{ ه } \\
\hline |درجة المواققة | & الترتيب & |المتوسط & درجة المواقتة & الترتيب & المتوسط & & \\
\hline أواقق & 18 & 3.98 & أواقق & 18 & 3.77 & |تخفيض النفقـات الحكوميـة علـى التعليـيـ & 12 \\
\hline أوافق بشدة & 7 & 4.43 & أوافق & 7 & 4.04 & |العامة إتيعاب أكبر علد من الحاصلين على الثانويـة & 13 \\
\hline أوافق بشلة & 12 & 4.34 & أواقق & 9 & 4.02 & | الأعمال يحقـق اللامركزيــة في التخطـيطوتنفيــذ| & 14 \\
\hline أوافق بشلة & 3 & 4.51 & أواقق & 3 & 4.15 & 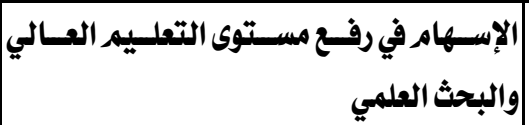 & 15 \\
\hline أواقق & 17 & 4.15 & أواقق & 17 & 3.79 & 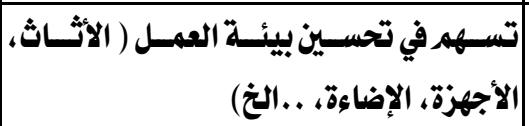 & 16 \\
\hline محايد & 19 & 3.30 & أواقق & 8 & 4.02 & |المتدنية & 17 \\
\hline أوافق بشدة & 14 & 4.28 & أواقق & 10 & 4.00 & |الأزمات & 18 \\
\hline أواقق بشلة & 15 & 4.28 & أواقق & 11 & 3.92 & 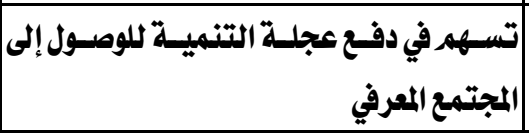 & 19 \\
\hline |أواقق بشدة & & S.T. & أواقق & & $r .97$ & الايجابيات ككل & \\
\hline
\end{tabular}

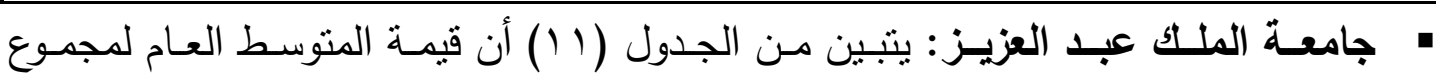
ايجابيات الخصخصة في مؤسسات التعليم العالي في المملكة العربية السعودية من وجهة

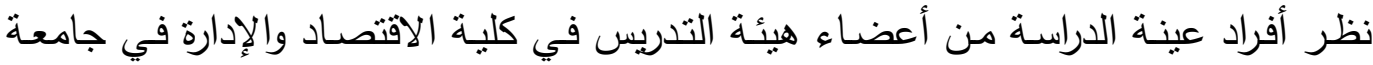

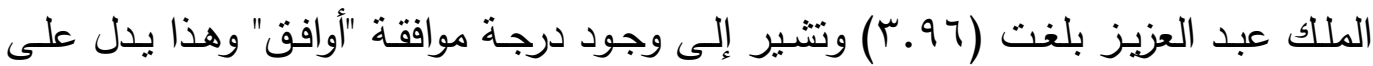

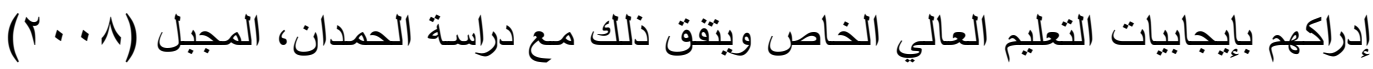

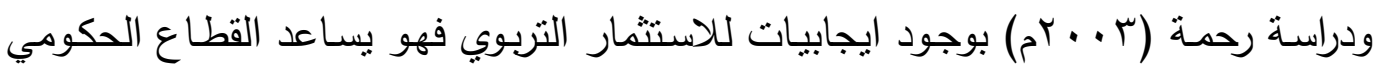

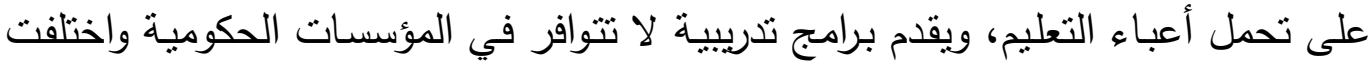
مع بالانياندي (Palaniandy, 2013) لاختلاف المجتمع (ماليزيا). " وحصلت فقرات الايجابيات للخصخصة على منوسطات حسابية تقع ما بين درجة "أوافق"

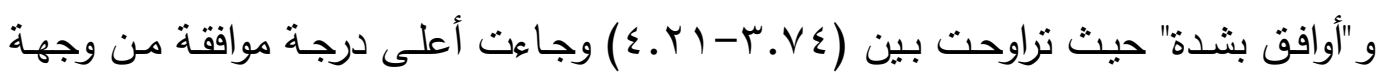

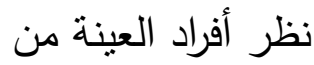


• أعضـاء هيئة التدريس في كلية الاقتصـاد والإدارة في جامعـة الملك عبد العزيز للفقرة

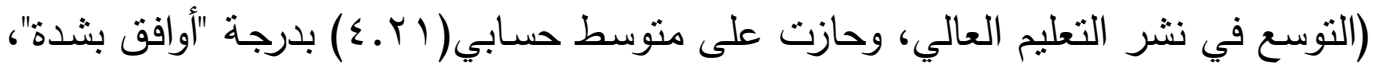

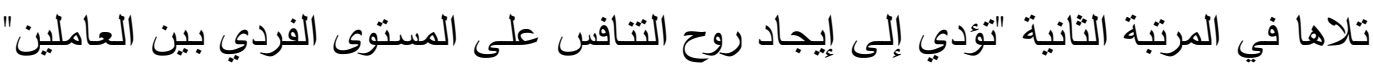

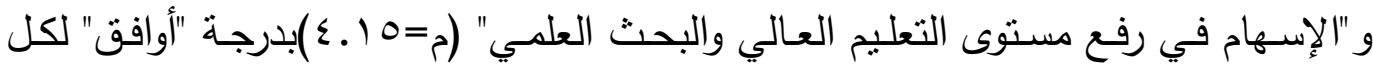
منهما؛ وهذا الأمر طبيعي ومنطقي وتعزو الباحثانة ذلك نتيجة لزيادة الطلب على التعليم

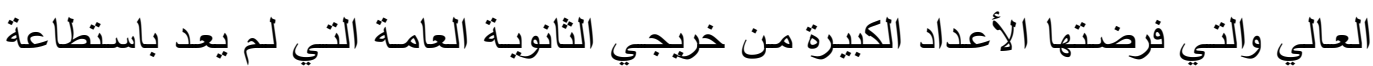

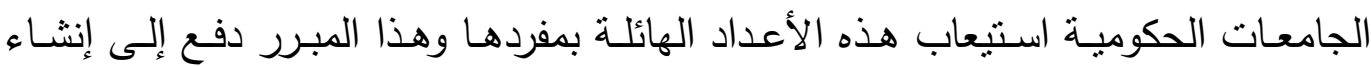

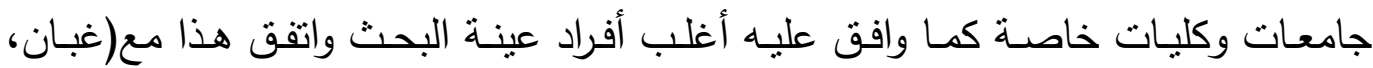

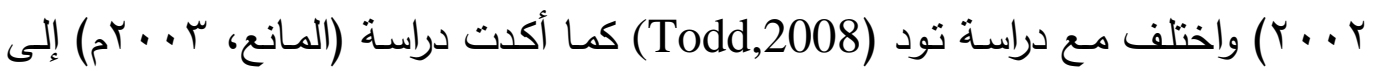

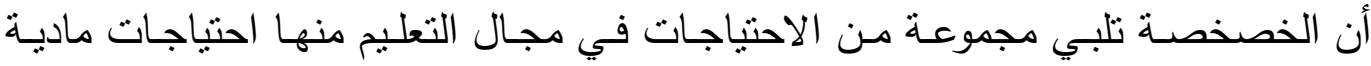

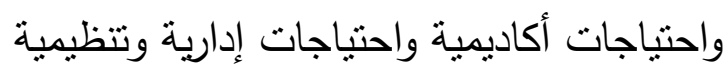

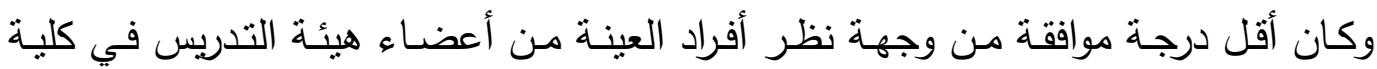
الاقتصاد والإدارة في جامعة الملك عبد العزيز كانت للفقرة "تخفيض النفقات الحكومية على التى

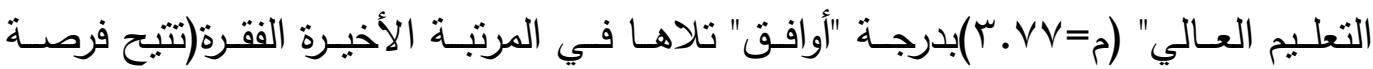

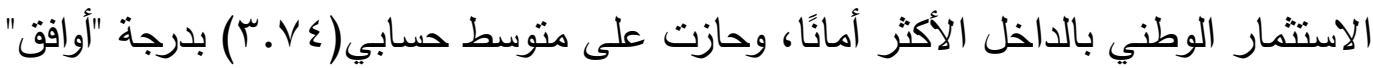

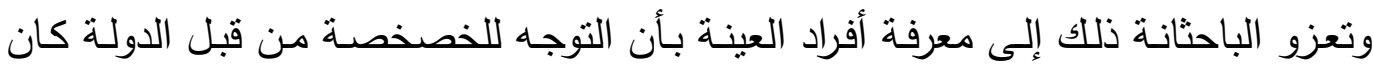
لأهداف أكاديمية مما يدل على أن قضية التعليم وإصلاح عيوبة ذليه من أهم القضايا التعليمية

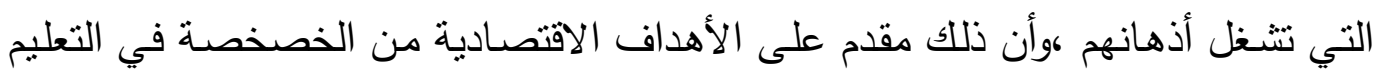
كأللاك لم يشغل هذا الأمر أفراد العينة.

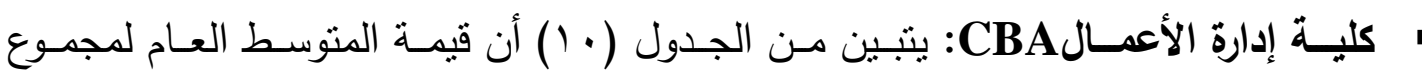

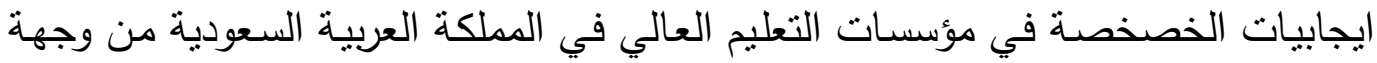

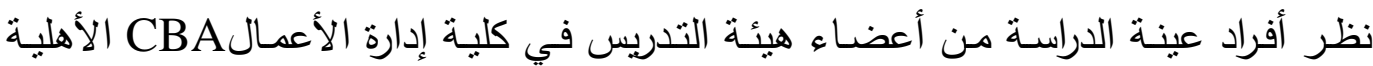

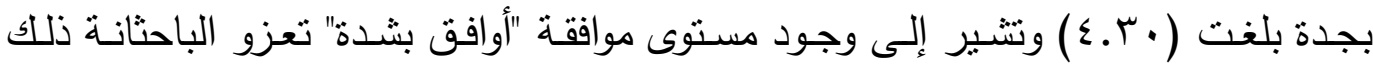

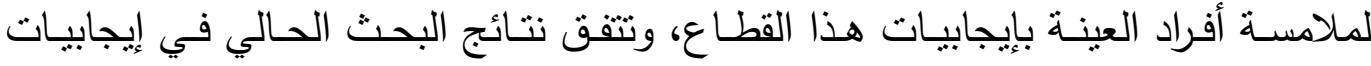

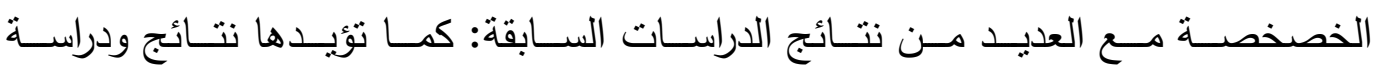

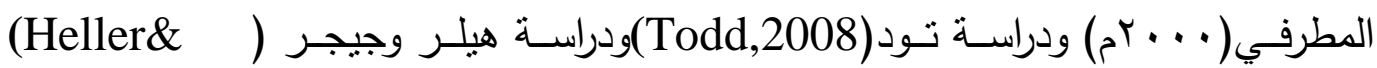
Geiger,2011 ودراسة كلارك( Clark,2000) أن الخصخصة تؤدي إلى عوائد مادية، وتبني طرق وأساليب إدارية حديثة وتنساعد في إيجاد فرص عمل. 
وحصلت فقرات الايجابيات للخصخصة على متوسطات حسابية تقع ما بين درجة "محايد"

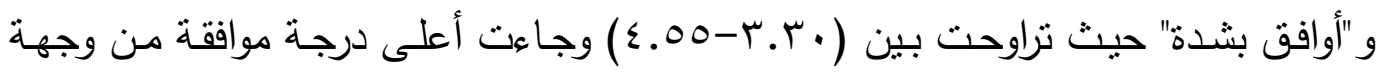

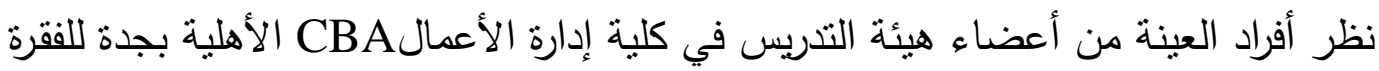

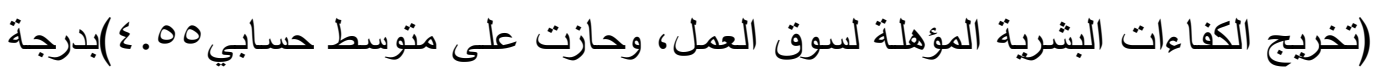

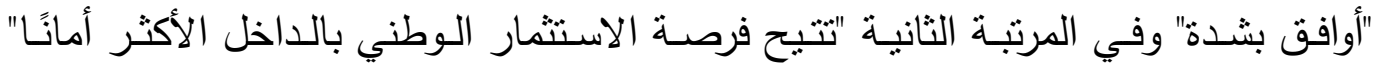

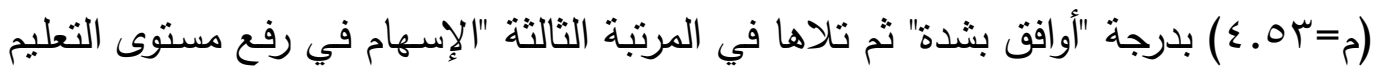

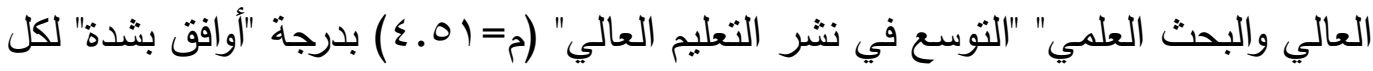

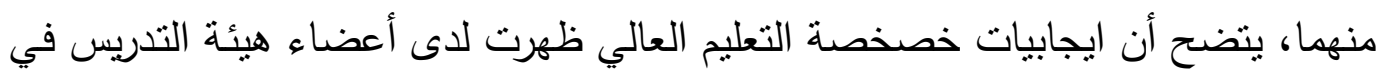

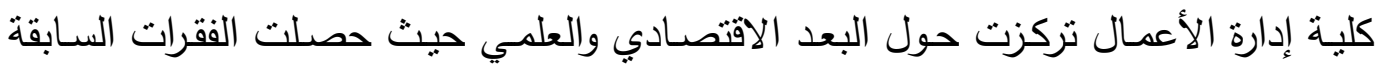

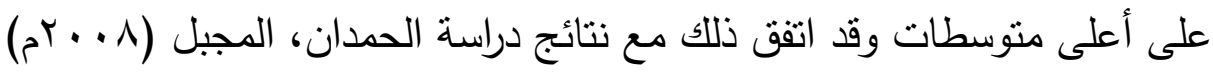
وكان أقل درجة موافقة من وجهة نظر أفراد العينة من أعضاء هئسئة التدريس في كلية إدارة

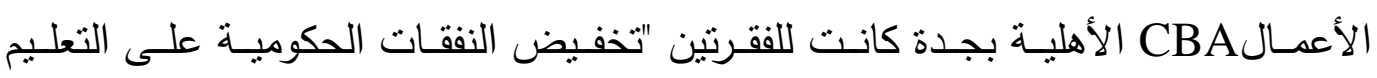

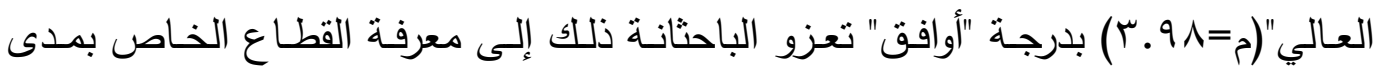

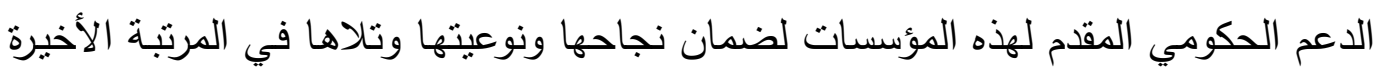

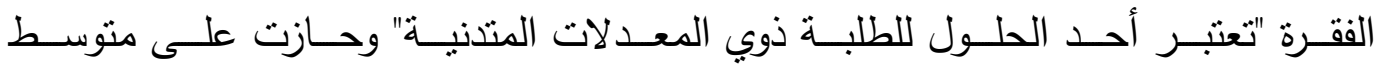

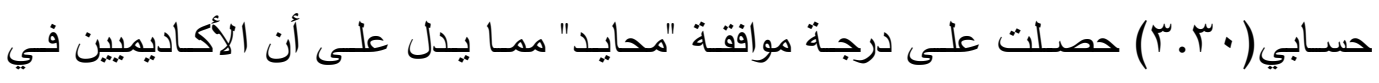

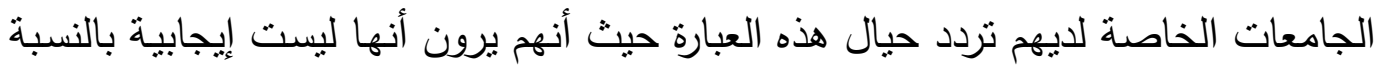

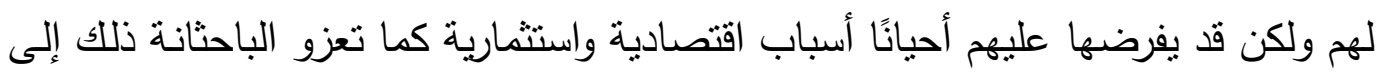

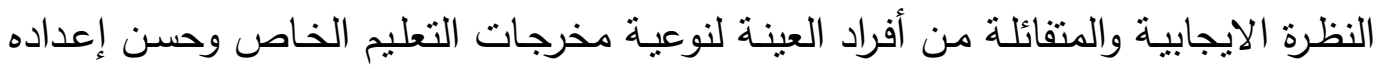

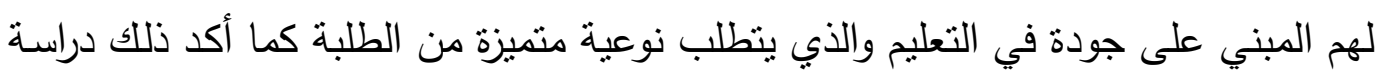

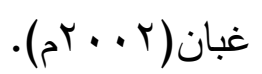

ونخلص من هذا المحور إلى أن أفراد العينـة يؤيدون الخصخصـة كونها تسـاعد في

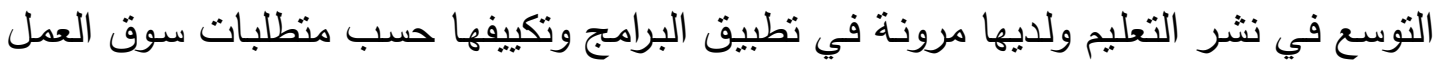
والاستفادة من خبرات الثريك الأجنبي كما أن القطاع الخاص أكثر قدرة على لفئ استثمار الموارد 
السؤال الثالث: ما السلبيات التي تعوق التوسع في الخصخصة في مؤسسات التعليم العالي في

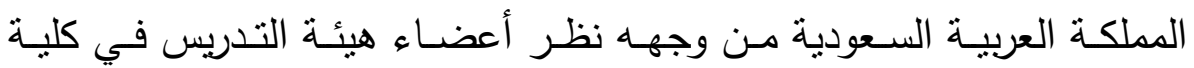

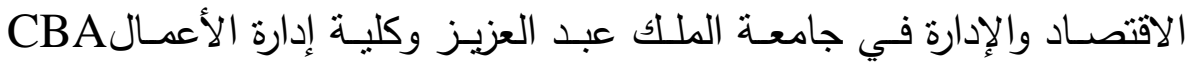

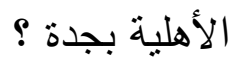

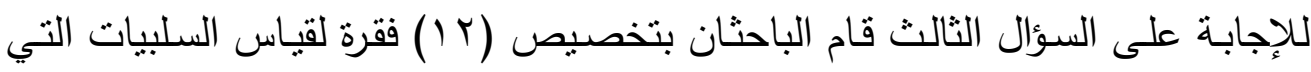

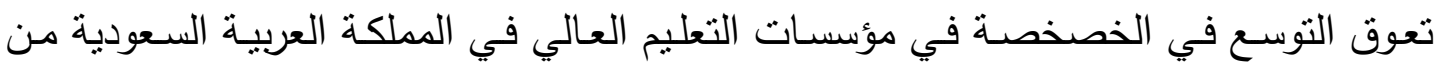

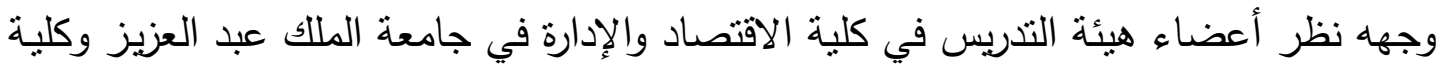

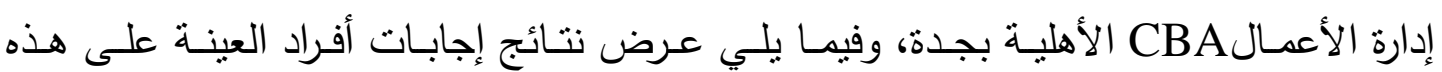

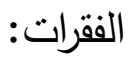

\section{جدول رقمر(ir)}

المتوسطات الحسابية والانحرافات المعياريةوالترتيب لفقرات السلبيات التي تعوق التوسع في الخصخصة في مؤسسات التعليهر العالي في المملكة العربية السعودية العماتية

\begin{tabular}{|c|c|c|c|c|c|c|c|}
\hline \multicolumn{3}{|c|}{ كلية إدارة الأعمالCBA الأهلية } & \multicolumn{3}{|c|}{ الاقتصادوالإدارة في جامعة الملكك عبد التلدئ } & \multirow[t]{2}{*}{ الفقــــــــــــــات } & \multirow[t]{2}{*}{ هـ } \\
\hline ل درجة المواققة & الترتيب & المتوسط & | درجة المواققة & الترتيب & المتوسط & & \\
\hline لاوأواقق & 10 & 2.49 & أواقق & 7 & 3.66 & | ارتقاع تكاليف الدراسة & 1 \\
\hline أوافق & 3 & 3.83 & 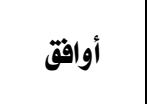 & 10 & 3.49 & | تكلفتهـ & 2 \\
\hline ل ألاواقق & 9 & 2.51 & أواقق & 4 & 3.89 & التساهل في منح الشهادات والدرجات العلمية & 3 \\
\hline ل ال أواقق & 11 & 2.43 & 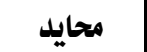 & 12 & 2.96 & | احتكار الخدمات التعليمية المتميزة & 4 \\
\hline ل الاواقق & 12 & 2.42 & | أواقق بشلة & 1 & 4.43 & | تحول التعليم العالي إلى سلعة تجارية & 5 \\
\hline 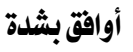 & 1 & 4.28 & 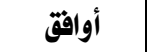 & 3 & 3.89 & |خفض رواتب أعضاء هيئة التدريس & 6 \\
\hline محايد & 8 & 2.64 & 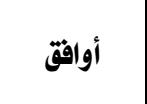 & 5 & 3.87 & | تكلفته المادية جـودة التعليه العـالي فيـه مـن أجسل خفضض & 7 \\
\hline أواقق & 5 & 3.64 & محايد & 11 & 3.34 & | مقارنة حجالتعليه (استقطابه لنسب ضئيلة جداً من الطلبـة & 8 \\
\hline أواقق & 2 & 4.00 & 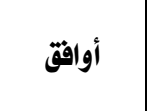 & 6 & 3.83 & | النظــرة السـلبية اتجــاه مؤسسـات التعليـيـ العـالي & 9 \\
\hline 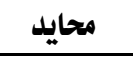 & 7 & 2.89 & أواقق & 9 & 3.58 & تواجده غالبًا في مقرات (مباني) غير ملائمة & 10 \\
\hline أواقق & 4 & 3.74 & أوافق & 8 & 3.60 & | تمركزه في المدن الكبيرة ( الرياض، جدة ) & 11 \\
\hline أواقت & 6 & 3.57 & أواقق & 2 & 3.92 & تفاوت المستويات الاكاديمية للمؤسسات التعليمية & 12 \\
\hline محايل & & r.r. & أواقق & & $r . v 1$ & السلبيات ككل & \\
\hline
\end{tabular}


• جامعة الملك عبد العزيز : يتبين من الجدول (r () قيمة المتوسط العام لمجموع السلبيات

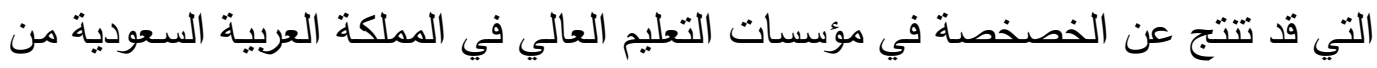

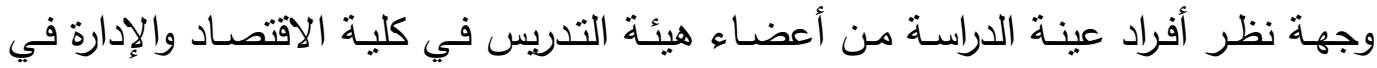

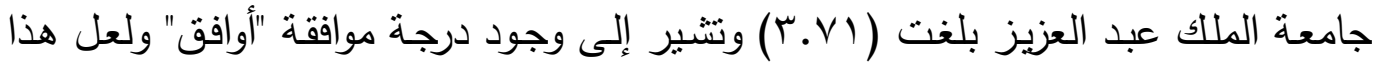
يظهر اتفاق على تخوف العينة بشكل عام من طغيان الربحية على حساب جودة التعليم

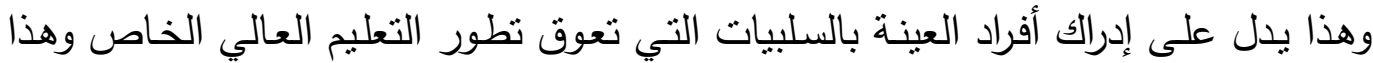

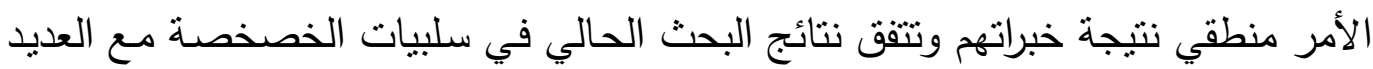

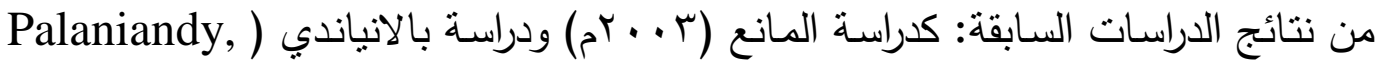
2013) والرباعي(1 ( • rم) ودراسة بابو (Babu,2011). وحصلت فقرات سلبيات الخصخصـة على منوسطات حسابية تقع ما بين درجـة "محايد"

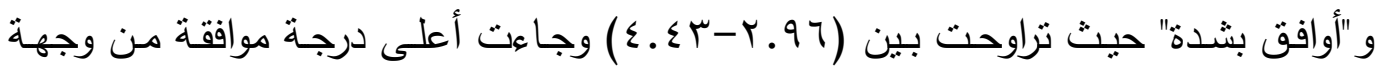

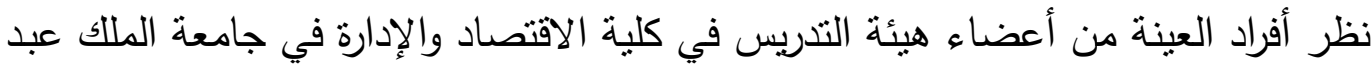

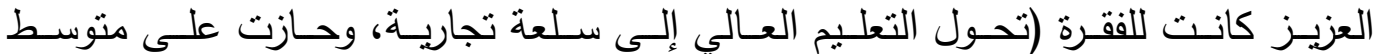

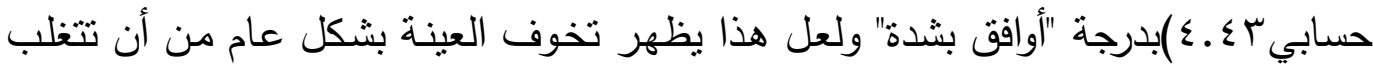
الرغبة في الربح المادي على المستوى التعليمي، فينخفض مستوى خريجي التعليم العالي

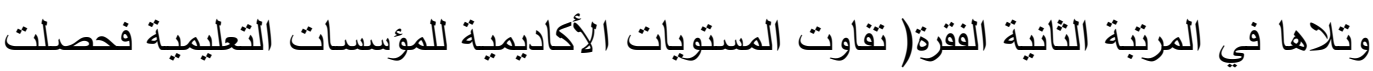

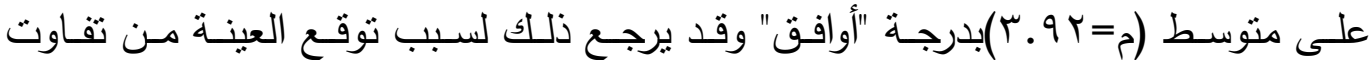
مستويات الاهتمامات الربحية لتلك المؤسسات فالجامعة والكلية القادرة ماديًا ستوفر بيئة

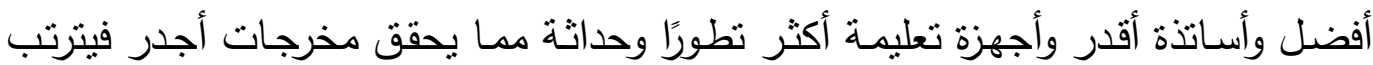
على ذلك رسوم دراسية مرتفعة فينحصر هذا النوع من التعليم على الأسر المقتدرة مما قد

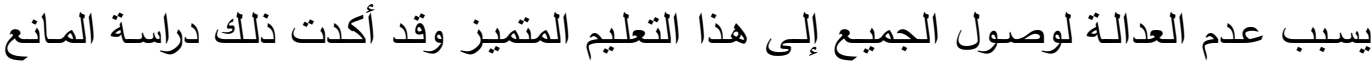

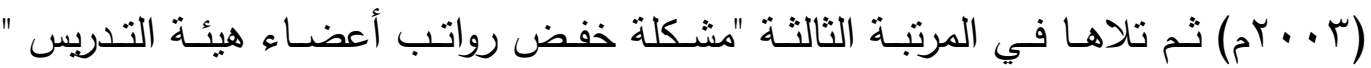

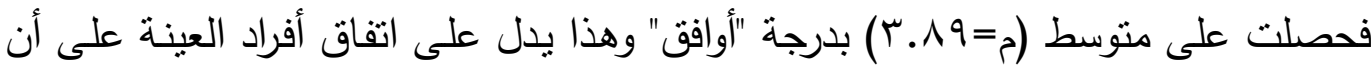
خفض الرواتب مقارنـة بـالحكومي مـن أهم الأسباب مـن وجهة نظرهم لعزوف الأسـاتذة السعوديين وغيرهم من الأكفاء عن التوظيف لديهم بالإضافة إلى أنه يسبب تسرب للموظفين

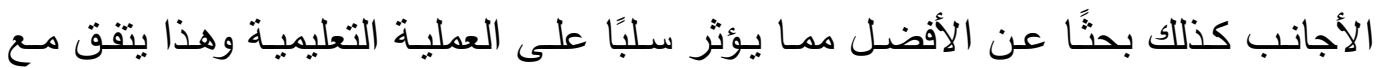

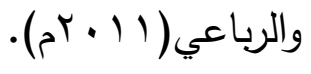


وكان أقل درجـة موافقة من وجهة نظر أفراد العينـة من أعضـاء هيئة التدريس في كليـة

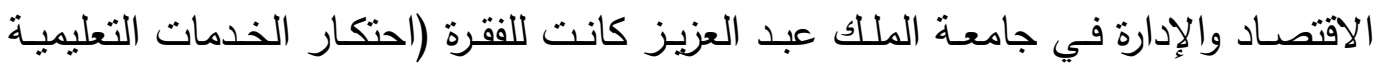

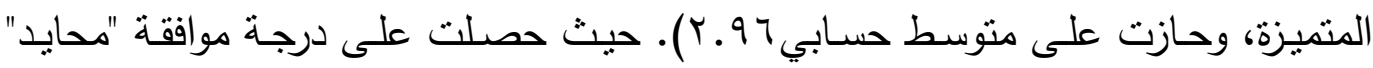

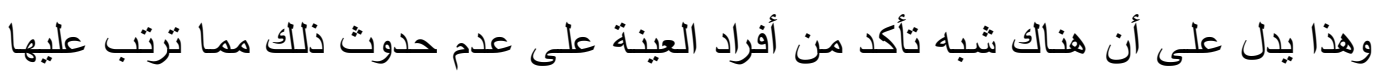

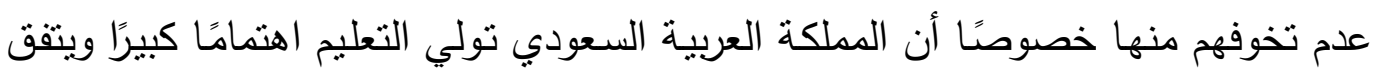

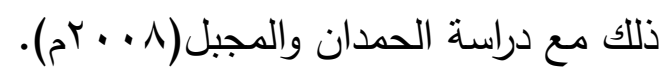

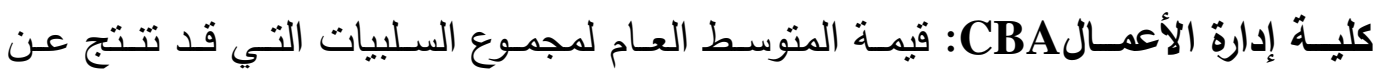

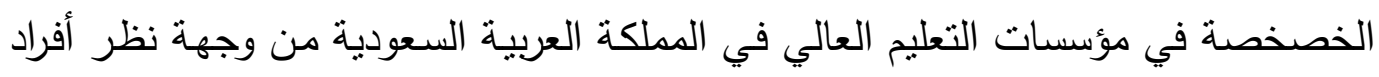

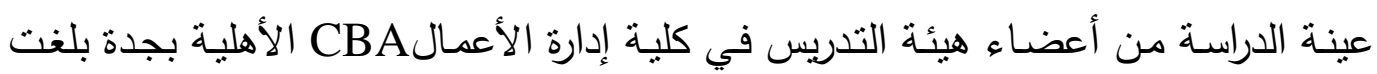

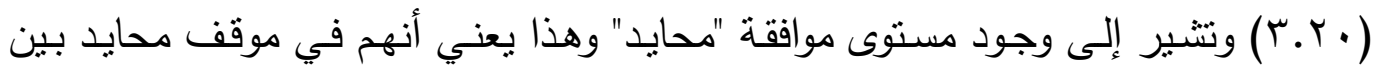

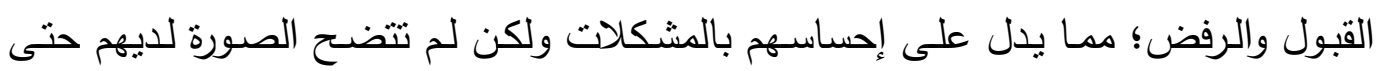

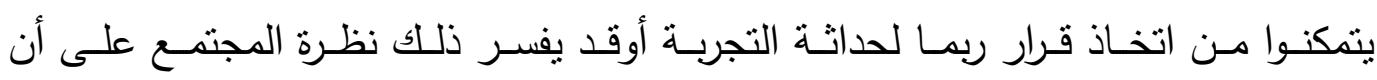

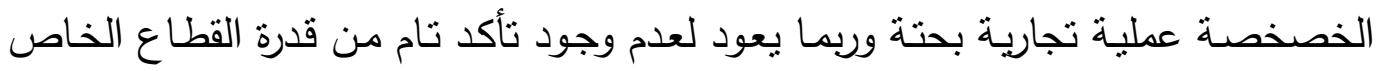

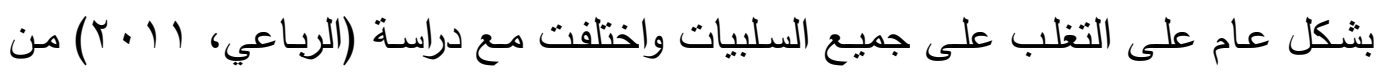

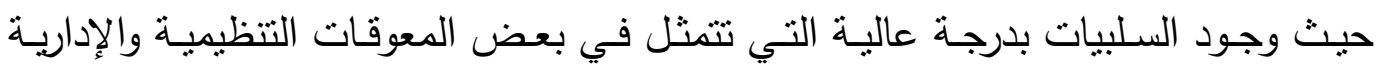
والمالية التي تسبب عزوف الكثير من المستثمرين.

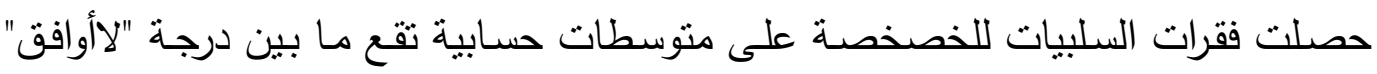

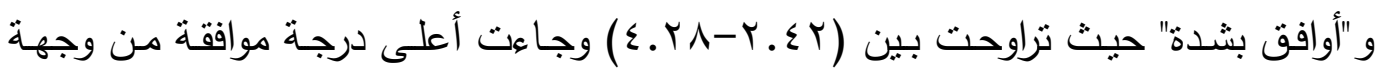

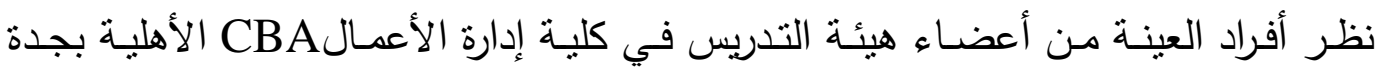

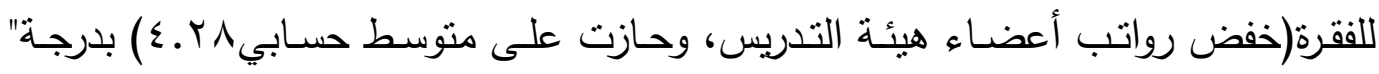

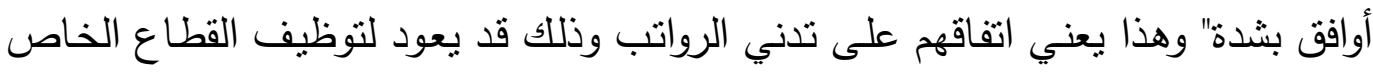

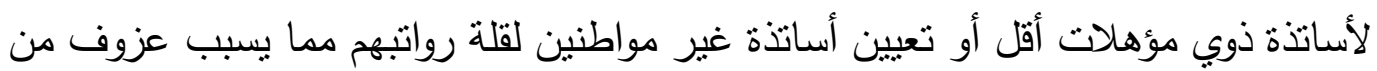

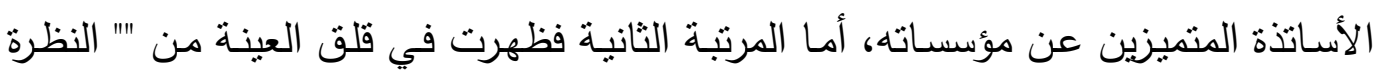

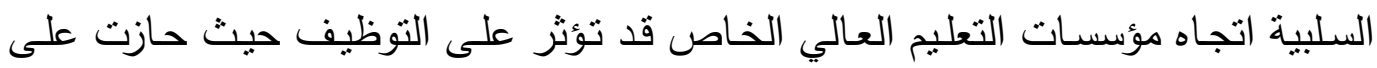

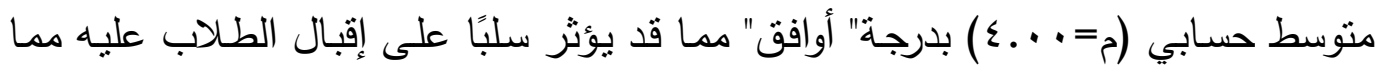

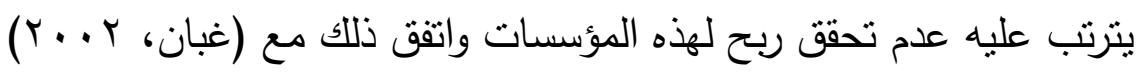

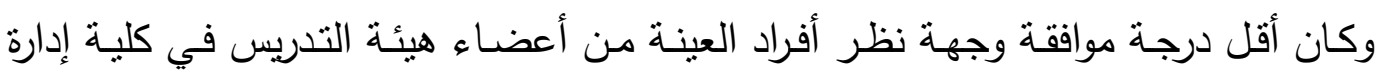

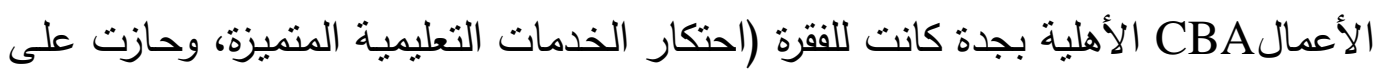


متوسط حسـابي بـ ـr)بدرجـة "لا أوافق" والمرتبـة الأخيرة للفقرة (تحـول التعليم العـالي إلى

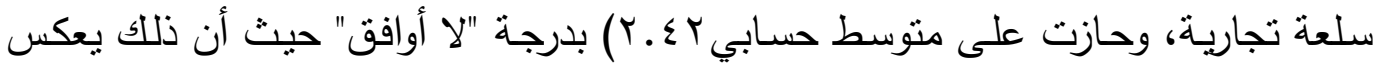
نظرة القطاع الخاص المتفائلة بعدم حدوث ذلك نظرًا لاهنمام المسئولين بالمستوى العلمي لاى مؤسسات التعليم العالي الخاصة. السؤال الرابـع: مـا الإجراءات المقترح تطبيقها للخصخصـة في المملكة العربية السعودية من وجهه نظر أعضاء هيئة التدريس في كلية الاقتصاد والإدارة في جامعة الملك

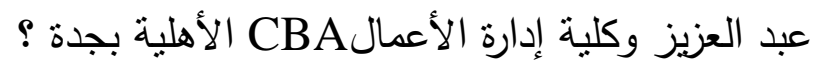

للإجابة على السؤال الرابع قام الباحثان بتخصيص (9 (1) فقرة لقياس الإجراءات المقترح

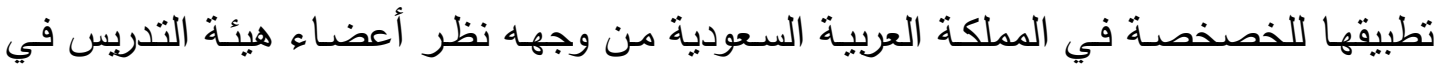
كلية الاقتصاد والإدارة في جامعة الملك عبد العزيز وكلية إدارة الأعمال وفيما يلي عرض نتائج إجابات أفراد العينة على هذه الفقرات:

جســلـول(r)

المتوسطات الحسابية والانحرافات المعيارية والترتيب لفقرات الإجراءات المقترح تطبيقها للخصخصة

في مؤسسات التعليه العالي في المملكة العربية السعودية

\begin{tabular}{|c|c|c|c|c|c|c|c|}
\hline \multicolumn{3}{|c|}{ كلية إدارة الأعمال بلجدة الأهلية } & \multicolumn{3}{|c|}{ الاقعضاء هيئة التدريس في كلية } & \multirow{2}{*}{ الفقـــــــــــــرات } & \multirow[t]{2}{*}{ م D } \\
\hline | درجة المواققة & الترتيب & المتوسط & المواققة & | الترتيب| & المتوسط & & \\
\hline | أوافق بشدة | & 9 & 4.38 & محايل & 19 & 3.17 & |مالية أكؤبر من قبل التعليه العـالي الخاصـة إعانـات & 1 \\
\hline | أوافق بشدة | & 1 & 4.68 & |أواقق بشدة & 6 & 4.26 & 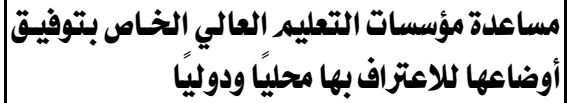 & 2 \\
\hline | أوافق بشلة & 5 & 4.55 & |أواقق بشدة & 5 & 4.38 & 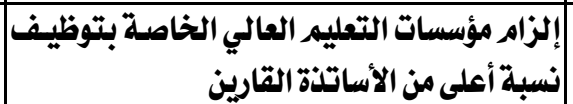 & 3 \\
\hline | أوافق بشدة | & 3 & 4.60 & أواقق & 10 & 4.15 & |زؤسيادة ساعات التعليم التداليب الخاص التطيق العملي في بـرامج & 4 \\
\hline | أوافق بشلة & 7 & 4.51 & أواقق & 11 & 4.09 & 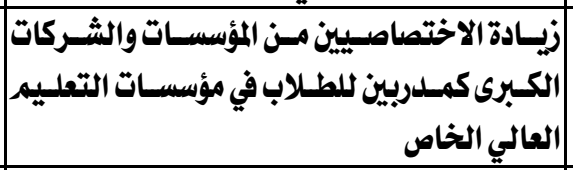 & 5 \\
\hline أواقق & 13 & 3.89 & |أوافق بشدة & 8 & 4.25 & |إنتلاء مؤسسة وطنية لمراقبة الالتزار بأخلاقيـات & 6 \\
\hline | أوافق بشلة & 4 & 4.60 & |أواقق بشدة & 4 & 4.55 & 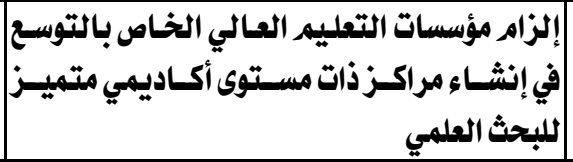 & 7 \\
\hline
\end{tabular}

TVM 


\begin{tabular}{|c|c|c|c|c|c|c|c|}
\hline \multicolumn{3}{|c|}{ كلية إدارة الأعمالCBA الأهلية } & \multicolumn{3}{|c|}{ أعضاء هيئة التدريس في كلية } & \multirow[t]{2}{*}{ الفقـــــــــــــــرات } & \multirow[t]{2}{*}{ مر } \\
\hline |درجة المواقتة & الترتيب & المتوسط & الموافقة & |الترتيب| & المتوسط & & \\
\hline أواقق & 16 & 3.68 & | أوافق بشدة & 1 & 4.75 & 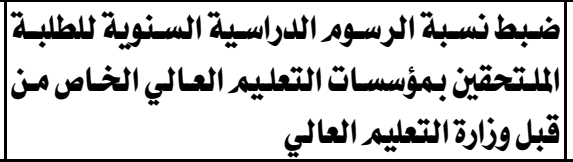 & 8 \\
\hline | أوافق بشدة & 2 & 4.62 & أواقق & 13 & 3.89 & |زئادة عدد المنتح الدراسية مـن الدولـة للطلاب في & 9 \\
\hline محايل & 17 & 2.94 & أواقق & 16 & 3.55 & 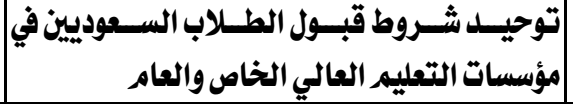 & 10 \\
\hline أواقق & 14 & 3.79 & أواقق & 12 & 3.91 & 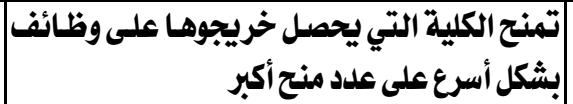 & 11 \\
\hline | أواقق بشدة & 6 & 4.55 & | أوافق بشدة & 7 & 4.26 & | الحككومي التعاون بين التعليــ العالي الخـاص والعـالي| & 12 \\
\hline محايل & 18 & 2.89 & 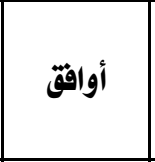 & 15 & 3.58 & 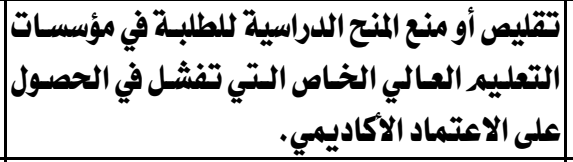 & 13 \\
\hline أواقق & 15 & 3.72 & محايل & 18 & 3.34 & | محليًا & 14 \\
\hline لا أواقق & 19 & 2.30 & أواقق & 17 & 3.47 & 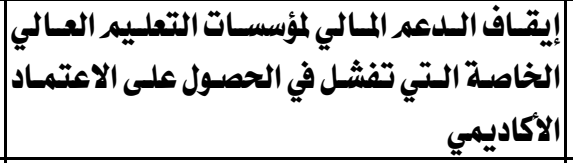 & 15 \\
\hline أواقق & 11 & 4.15 & | أوافق بشدة & 2 & 4.66 & | زالتعليه العالي الاكاديميين السعوديين في مؤسسات & 16 \\
\hline | أواقق بشدة & 10 & 4.34 & أواقق & 14 & 3.77 & | القطاعات النائية منح التراخيص للكليات الخاصة في & 17 \\
\hline | أواقق بشدة & 8 & 4.47 & | أواقق بشلة & 9 & 4.23 & 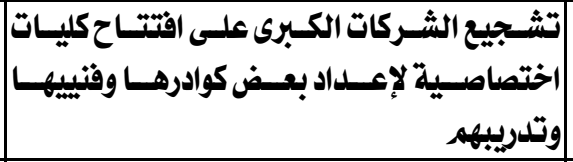 & 18 \\
\hline أوافق & 12 & 4.02 & | أوافق بشلة & 3 & 4.60 & 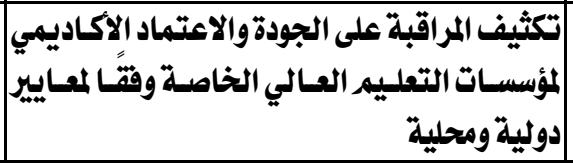 & 19 \\
\hline أواقق & & $\xi . \bullet \xi$ & أواقق & & $\xi . \cdot \xi$ & الاجراءات المقترحة ككل & \\
\hline
\end{tabular}

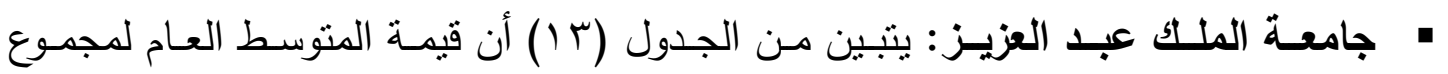
الإجراءات المقترح تطبيقها للخصخصـة في مؤسسـات التعليم العـالي في المملكة العربيـة السعودية من وجهة نظر أفراد عينة الدراسة من أعضـاء هيئة التدريس في كلية الاقتصاد 
والإدارة في جامعة الملك عبد العزيز بلغت (ع ...؟) وتشير إلى وجود درجة موافقة "أوافق"

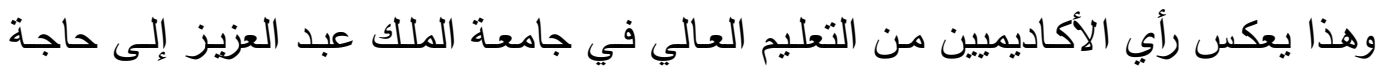

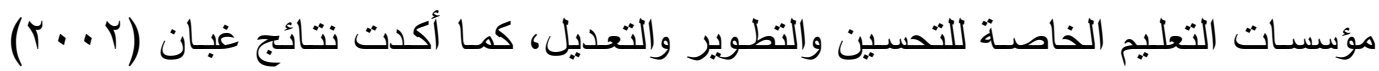

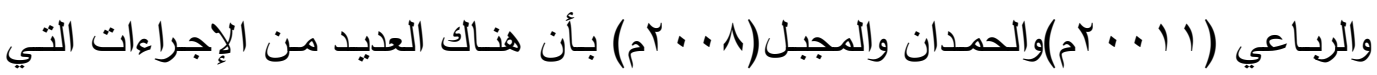

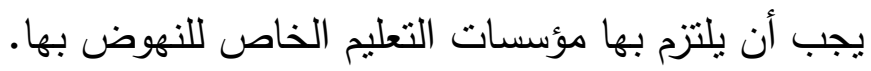

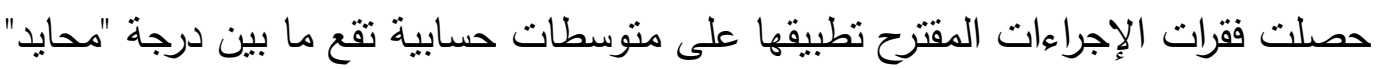

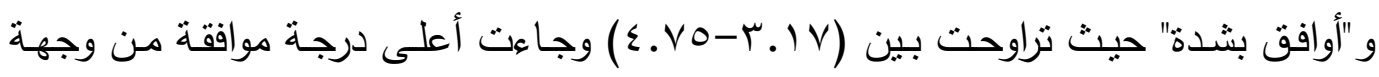
نظر أفراد العينة من أعضاء هيئة التدريس في كلية إدارة واقتصاد بجامعة المادئ الملك عبد العزيز

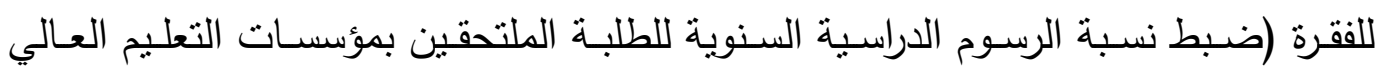

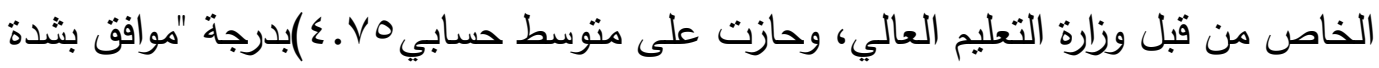

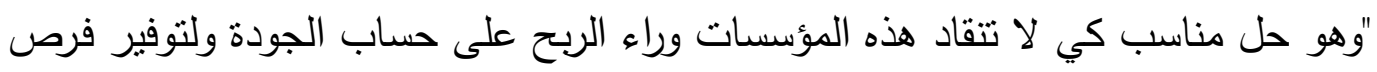

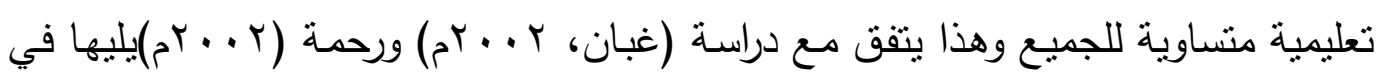

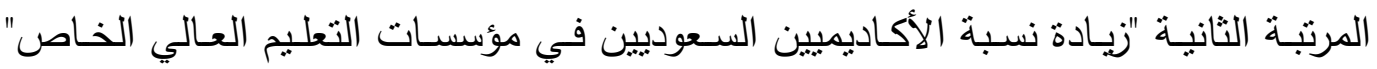

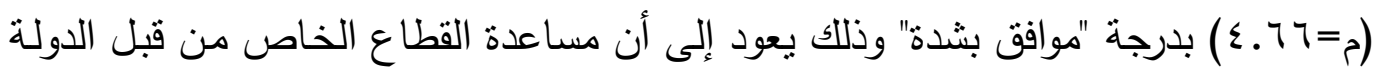

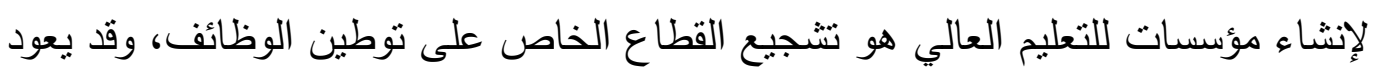
ذلك إلى تحقيق استقرار في البيئة التعليمية.

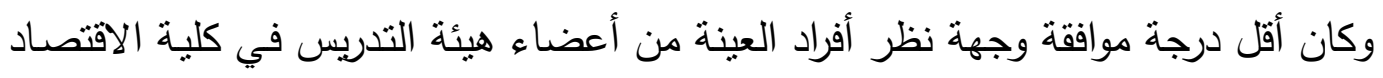

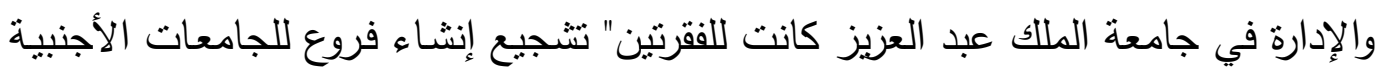

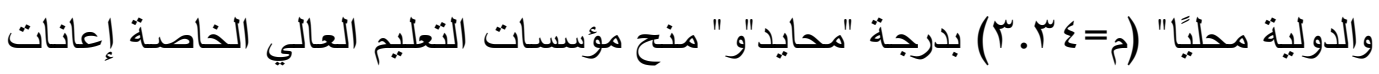

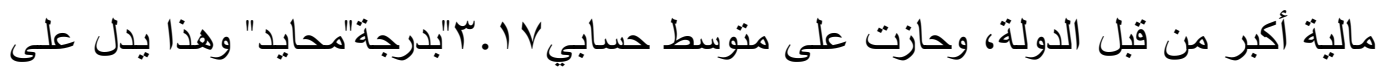

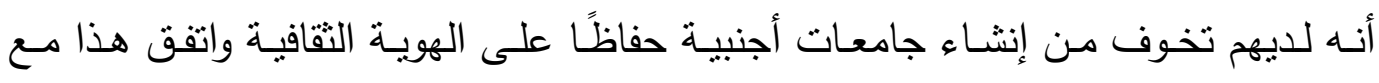

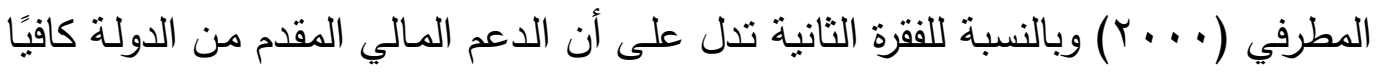

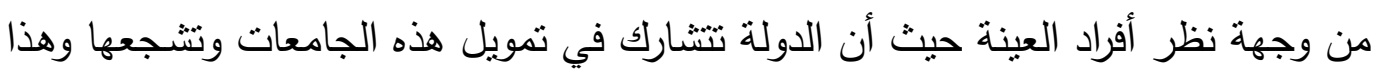

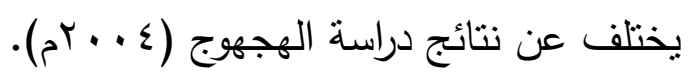

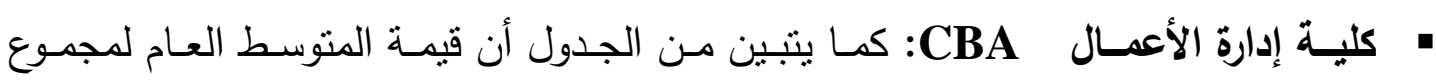
الإجراءات المقترح تطبيقها للخصخصـة في مؤسسـات التعليم العـالي في المملكة العربيـة 
السـودية مـن وجهـة نظر أفراد عينـة الدراسـة مـن أعضـاء هيئة التدريس في كليـة إدارة الأعمالCBA الأهلية بجدة بلغت (ع . ..ع) وتثتير إلى وجود مستوى موافقة "أوافق" وهذا يدل على حاجة التعليم العالي الخاص إلى ألى

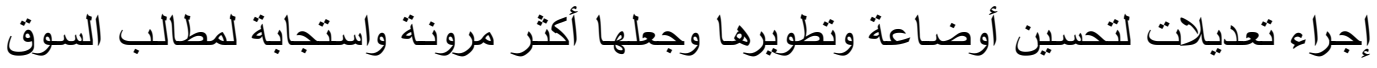
والمستهلك، ويتفق ذلك مع دراسة ماركوس (Marcos, 2003)

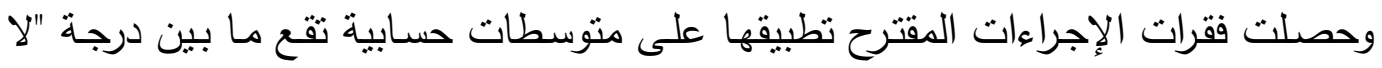

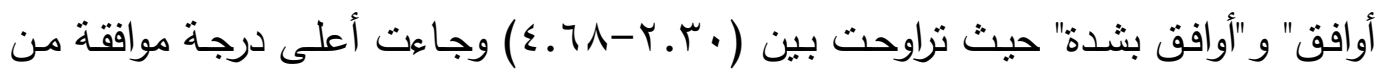

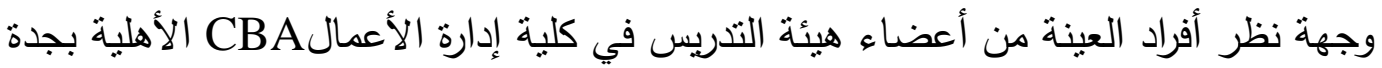

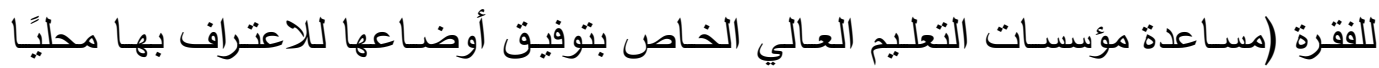

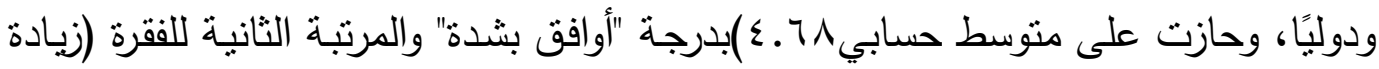

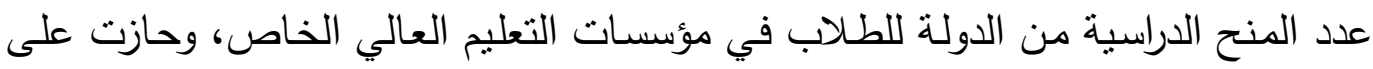

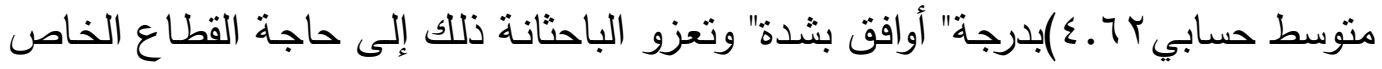

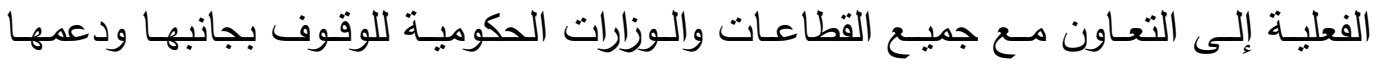

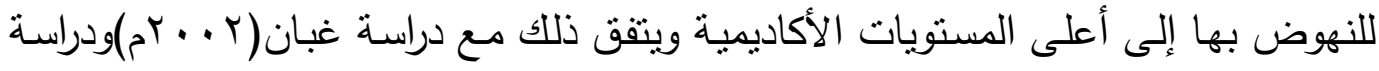

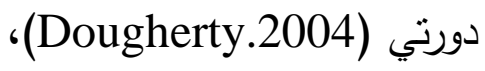
وكان أقل درجة موافقة من وجهة نظر أفراد العينة من أعضـاء هيئة التدريس في كلية إدارة

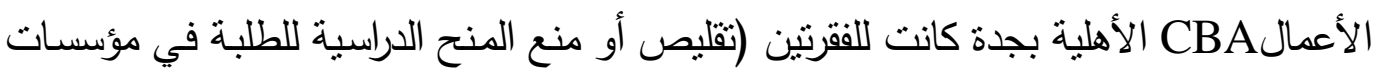

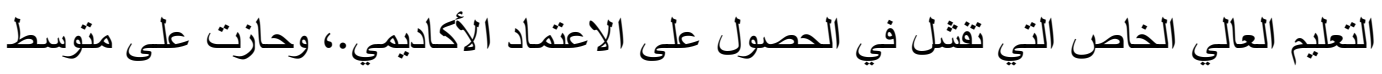

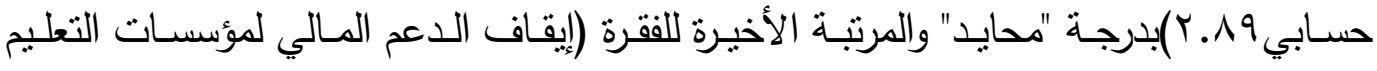

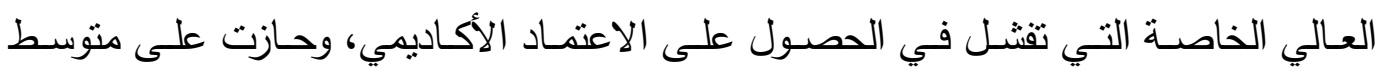

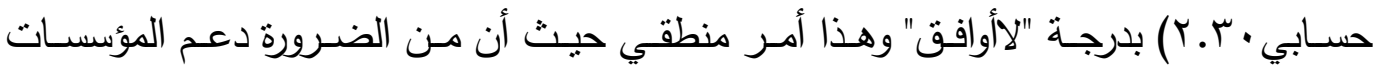

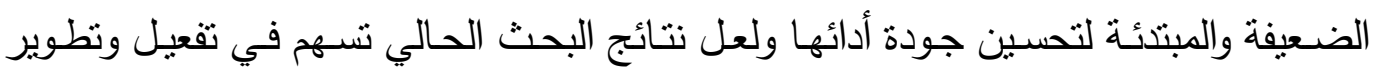

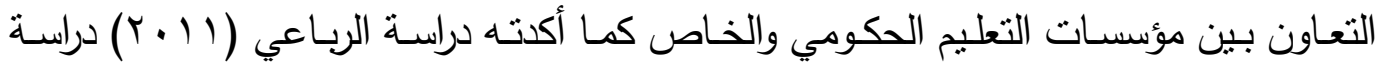

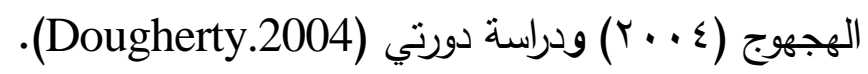
السؤال الخـامس: هل توجد فروق من وجهة نظر الأكاديميين على مجالات مقياس الدراسة

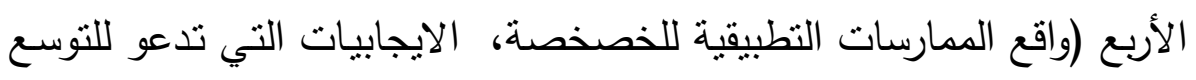


في خصخصـة التعليم العـالي، السلبيات التي تعـوق التوسـع في خصخصـة التعليم العالي، الإجراءات المقترح تطبيقها للخصخصـة في مؤسسات التعليم

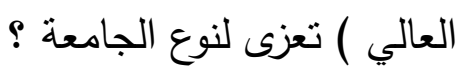
وللإجابة عن هذا السؤال تم فرض أربع فرضيات وسيتم شرح كل منها على حده:

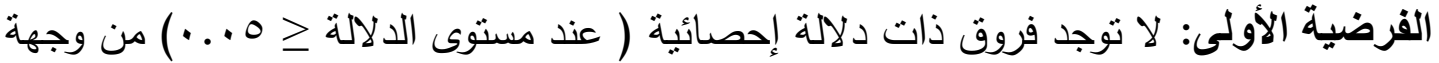

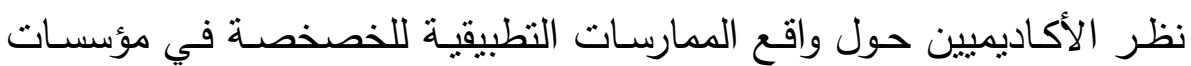
التعليم العالي في المملكة العربية السعودية نعزى لنوع الجامعة.

لبحث هذه الفرضية تم استخدام اختبار (ت) لعينتين مستقلتين ( Independent (Samples T-Test حول واقع الممارسـات النطبيقية للخصخصـة في مؤسسات التعليم العالي في المملكة العربية السعودية تعزى لنوع الجامعة ويوضح الجدول (ع () نتيجة الاختبار :

جلدول (i)

نتائج اختبار (ت) لعينتين مستقلتين (Independent Samples T-Test) للالالة الفروق بين

متوسطات استجابات أفراد عينة الدراسة

\begin{tabular}{|c|c|c|c|c|c|c|}
\hline مستوى & قيمة & الالانحراف & الحسابي & العدد & نوع الجامعة & المحور \\
\hline \multirow{2}{*}{0.693} & \multirow{2}{*}{0.396} & 0.433 & 3.43 & 53 & جامعة الملكد عبد العزيز & \multirow{2}{*}{ 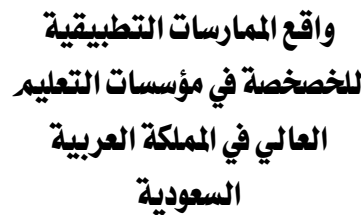 } \\
\hline & & 0.470 & 3.40 & 47 & كلية إدارة الأعمال & \\
\hline
\end{tabular}

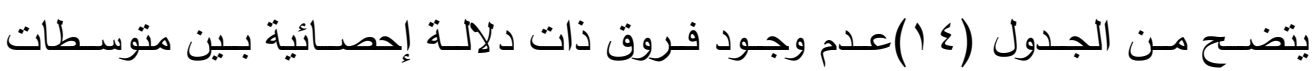
استجابات أفراد عينة الدراسة من الأكاديميين حول واقع الممارسات النطبيقية للخصخصة في

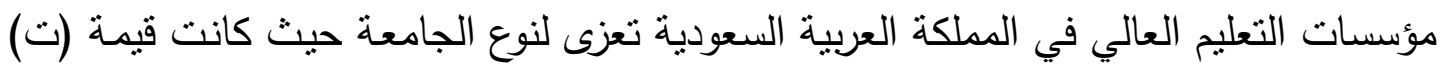
(0.396) وكان مستوى الدلالة (0.693)وهو مستوى غير دال، وهذا الاتفاق بين العام والخاص

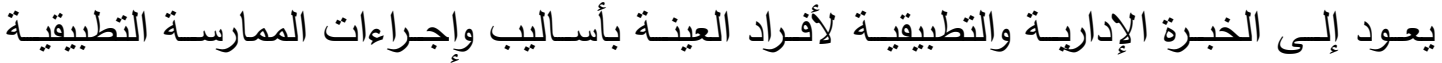

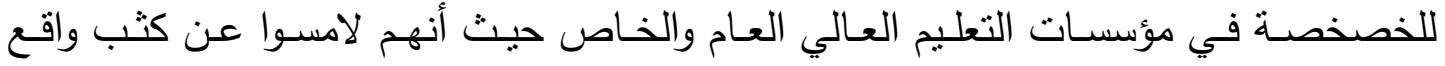
الجامعات الخاصة وما يمارس فيه من أساليب للخصخصة في مؤسسات التعليمة التهات العالي.

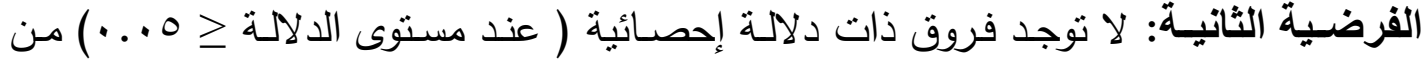

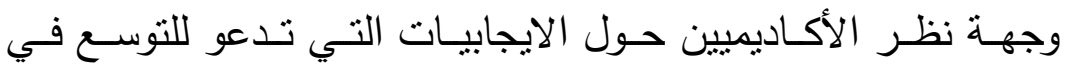


الخصخصة في مؤسسات التعليم العالي في المملكة العربية السعودية

$$
\text { تعزى لنوع الجامعة. }
$$

لبحث هذه الفرضية تم اسـتخدام اختبـار (ت) لعينتين مستقلتين ( Independent (Samples T-Test حول الايجابيات التي تدعو للتوسـع في الخصخصـة في مؤسسات التعليم العالي في المملكة العربية السعودية تعزى لنوع الجامعة ويوضح الجدول (0 1) نتيجة الاختبار جلول (10)

نتائج اختبار (ت) لعينتين مستقلتين (Independent Samples T-Test) للالة الفروق بين

\section{متوسطات استجابات أفراد عينة الدراسة}

\begin{tabular}{|c|c|c|c|c|c|c|}
\hline مستوى & قيمة (ت) & الانحراف & الحسابي & العلد & نوع الجامعة & سـور \\
\hline \multirow{2}{*}{$* 0.000$} & \multirow{2}{*}{$4.25-$} & 0.461 & 3.96 & 53 & جامعة الملك عبد العزيز & الايجابيات التي تدعو للتوسع \\
\hline & & 0.351 & 4.30 & 47 & كلية إدارة الأعمال & التعليم العالي في المملكة \\
\hline
\end{tabular}

*وجود دلالة عند مستوى ه ه ...

يتضـح من الجدول (0 1 ) وجود فروق ذات دلالـة إحصـائية بين منوسطات استجابات أفراد عينـة الدراسـة مـن الأكاديميين حول الايجابيـات التي تـدعو للتوسـع في الخصخصـة في مؤسسات التعليم العالي في المملكة العربية السعودية تعزى لنوع الجامعة لصالح أعضاء هيئة التدريس بكلية إدارة الأعمال الأهلية بجدة حيث كانت قيمة (ت) (-4.25) وكان مستوى الدلالة (0.000) وهو مستوى دال، وتعزو الباحثانة ذللك لكون الأكاديميين في التعليم الخاص أكثر قربًا بايجابيات هذا النمط من التعليم بالتالي يستشعرون تلك الايجابيات أكثر من الحكومي، وقد

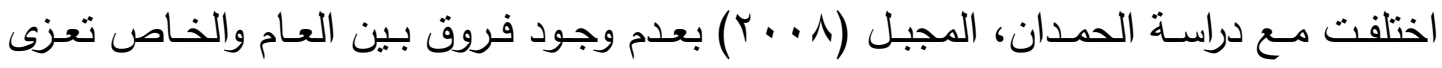
لاختلاف العينـة والمجتمع حيث انحصرت فقط على القيادات الأكاديميـة في مؤسسـات التعليم الخاص والعام في دولة الكويت. 


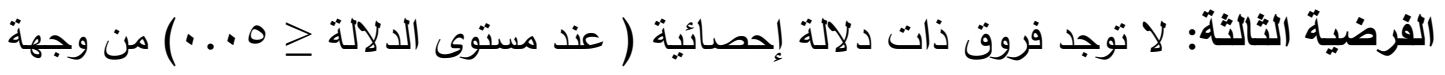

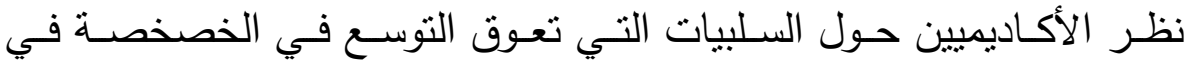
مؤسسات التعليم العالي في المملكة العربية السعودية تعزى لنوع الجامعة.

لبحث هذه الفرضية تم استخدام اختبار (ت) لعينتين مستقلتين ( Independent (Samples T-Test حول السلبيات التي تعوق التوسع في الخصخصـة في مؤسسات التعليم العالي في المملكة

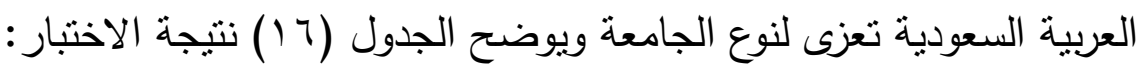

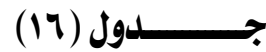

نتائج اختبار (ت) لعينتين مستقلتين (Independent Samples T-Test) للالالة الفروق بين متوسطات استجابات أفراد عينة الدراسة

\begin{tabular}{|c|c|c|c|c|c|c|}
\hline مستوى & قيمة (ت) & الالمعياري & المسابي & العدد & نوع الجامعة & المحور \\
\hline \multirow{2}{*}{$* 0.000$} & \multirow{2}{*}{3.93} & 0.493 & 3.71 & 53 & جامعة الملك عبلد العزيز & الخصخيلة في مؤسسات التعليم \\
\hline & & 0.743 & 3.20 & 47 & كلية إدارة الأعمال & العالي في المملكة العربية \\
\hline
\end{tabular}

*وجود دلالة عند مستوى ه...

يتضح من الجدول (7 (1) وجود فروق ذات دلالة إحصائية بين متوسطات استجابات

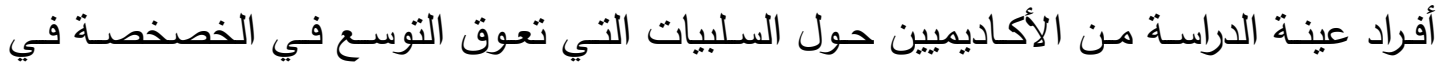

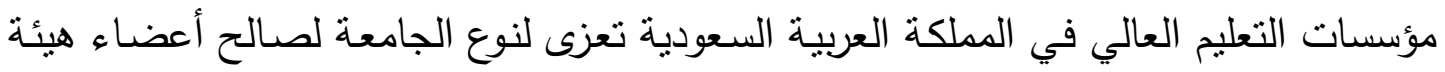
التدريس بكلية الاقتصاد والإدارة بجامعة الملك عبد العزيز بجدة حيث كانت قيمة (ت) (3.93) وكان مستوى الدلالة (0.000) وهو مسنتوى دال، ولعل ذللك يعود إلى إدرالك مسئولي التعليم

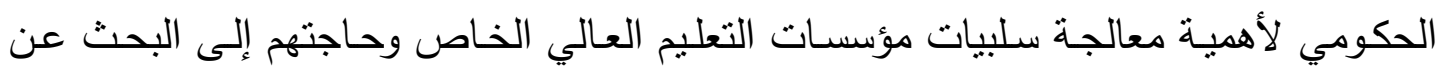
حلول في ظل عدم مقدرة بعض الجامعات والكليات الوفاء بمتطلبات جودة العطلية التعليمية

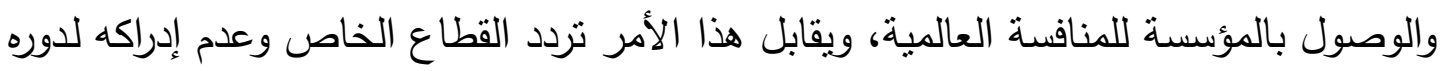

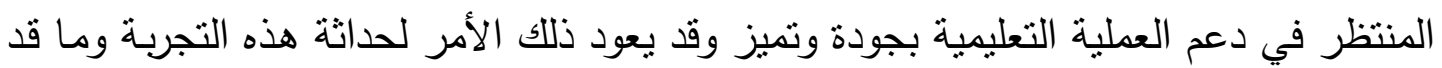

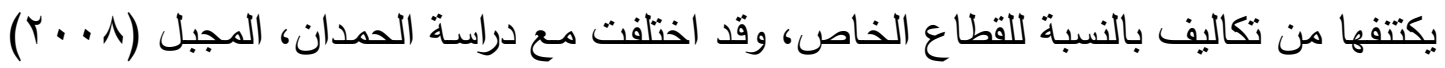
في ذلك ويرجع إلى اختلاف مجتمع البحث، واختلاف مدة التجربة حيث أن تجربة التعليم العالي دئي rva 
الخـاص بالكويت أكثر حداثة من المملكة العربية السعودية فلذلك من الصعب الجزم بتلك

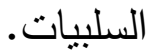

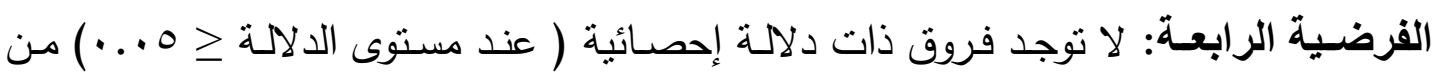

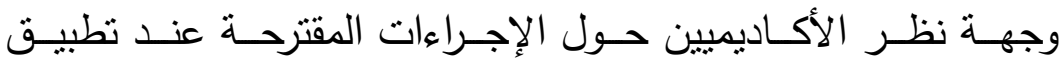
الخصخصة في مؤسسات التعليم العالي في المملكة العربية السعودية

$$
\text { تعزى لنوع الجامعة. }
$$

Independent ） لبحث هذه الفرضية تم استخدام اختبار (ت) لعينتين مستقلتنين (Samples T-Test حول الإجراءات المقترحة عند تطبيق الخصخصـة في مؤسسـات التعليم العـالي في المملكة

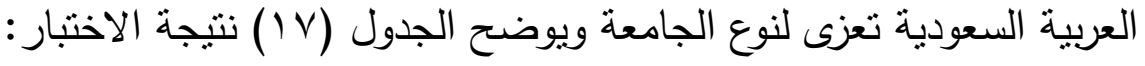
جدول (iv) (2)

نتائج اختبار (ت) لعينتيز مستقلتيز (Independent Samples T-Test) لدلالة الفروق بيز متوسطات استجابات أفراد عينة الدراسة

\begin{tabular}{|c|c|c|c|c|c|c|}
\hline مستوى & قيمة (ت) & الالمعياري & الحسابي & العدد & نوع الجامعة & المحور \\
\hline \multirow{2}{*}{0.999} & \multirow{2}{*}{$0.001-$} & 0.286 & 4.04 & 53 & جامعة الملك عبل العزيز & الخصخصة في مؤسسات التعليه \\
\hline & & 0.422 & 4.04 & 47 & كلية إدارة الأعمال & العالي في المملكة العربية \\
\hline
\end{tabular}

يتضـح مـن الجدول (IV) عدم وجـود فـروق ذات دلالــة إحصـائية بـين متوسطات استجابات أفراد عينة الدراسة من الأكاديميين حول الإجراءات المقترحة نطبيقها للخصخصة في

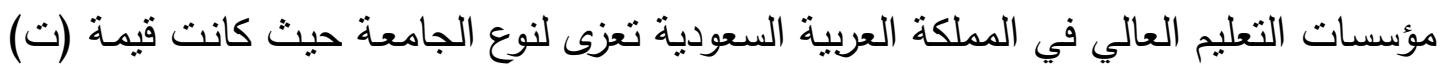

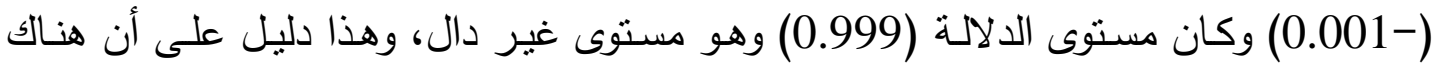

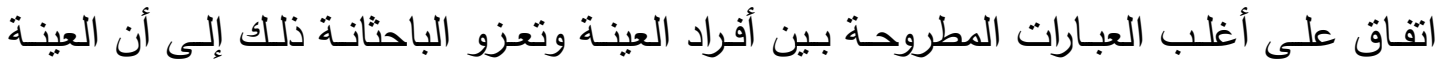

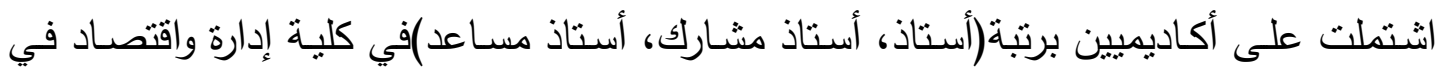

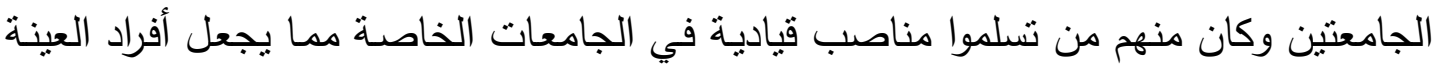

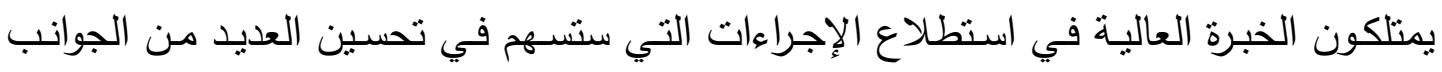
التنظيمية والتعليمية والإدارية التي يفتقدها التعليم الجامعي الخاص وهذا كله يبرر عدم حصول 


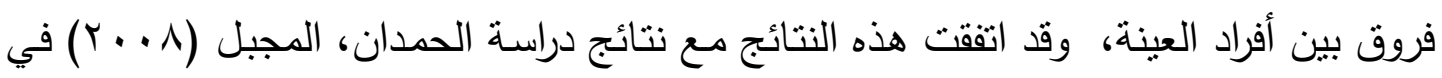

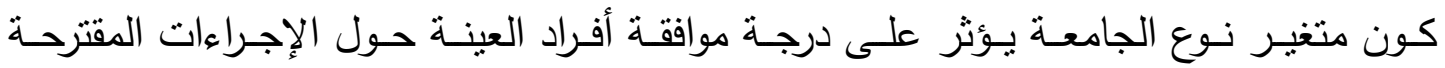

للخصخصة في التعليم العالي.

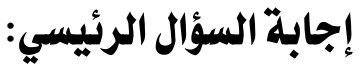

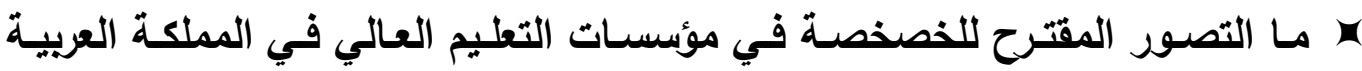

السعودية؟ من

في ضوء نتائج الإطار النظري، ونتائج البحث الحالي يمكن التوصل لوضـع تصـور

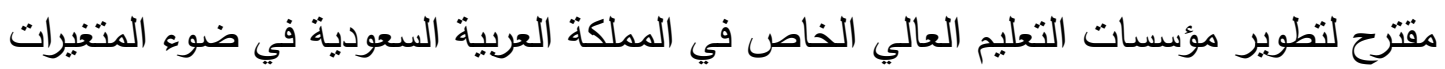

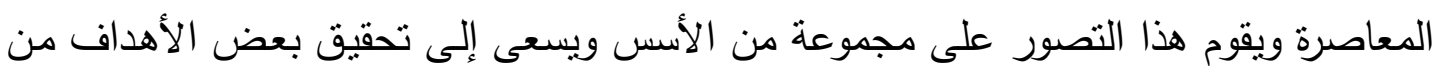

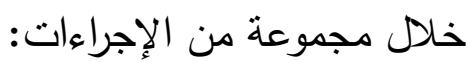

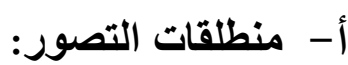

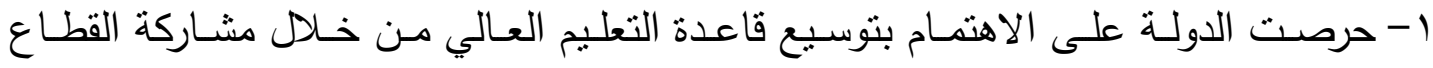

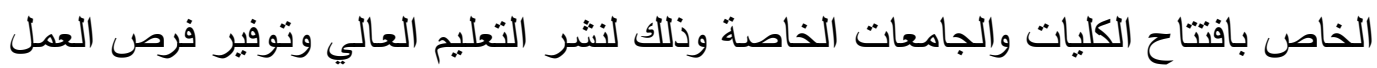
وتوطين الوظائف والمواءمة بين المخرجات وسوق العمل واستحداث الصيخ الجديدة التي

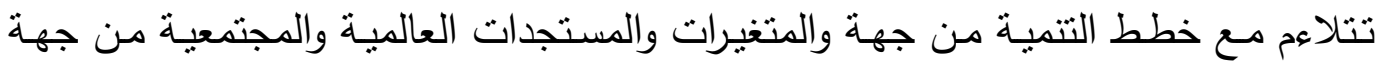

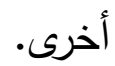

r- أكدت نتائج البحث على أن واقع التعليم العالي الخاص يشهد مجموعة من السلبيات التي تعوق تطوير ونمو هذا القطاع بشكل إيجابي.

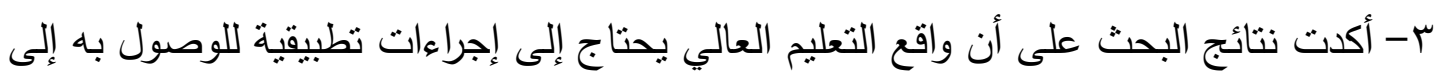
أعلى المستويات الأكاديمية. ع - تأكيد مسئولي الجامعات والكليات الحكومية والخاصـة على أهمية التعليم العالي الخاص

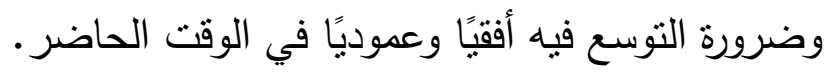

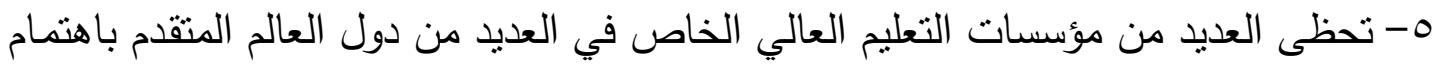

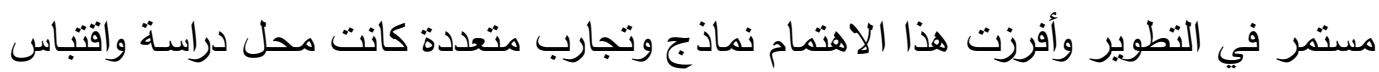
من قبل العديد من دول العالم لتطوير هذا النوع من التعليم.

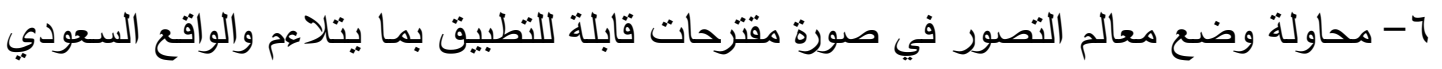

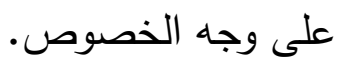


ب- - أسس وفلسفة التصور:

تقوم أسس وفلسفة التصور المقترح على ما يلي:

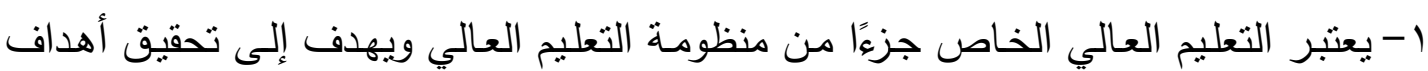

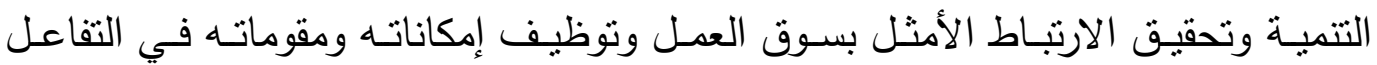
المستمر مع المتغيرات المحلية والعالمية . ץ- الأحداث العالمية المعاصرة أبرزت الحاجة إلى إدخال تغييرات في النظام التعليمي بصفة عامة تتناسب مع نلك المستجدات. r- الطلب المتزايد من سوق العمل على نوعية ذات كفاءة عالية ومدربة من خريجي التعليم العالي الخاص تتوفر فيهم المهارات الكافية لسد احتياجات العمل. ع - قدرة بعض الجامعات والكليات الخاصـة العربية والمحلية والعالمية على إحداث التغييرات

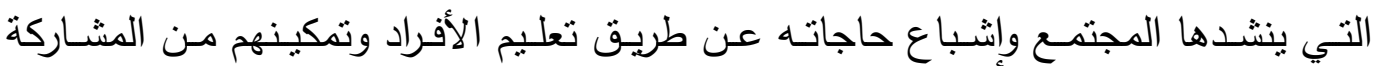
الإيجابية في برامج التنمية.

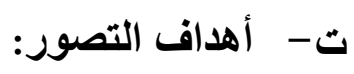

من خلال العرض السابق لقلفة وأسس التصور المقترح يمكن تحديد أهدافه فيما يلي: 1- تتمية قدرة مؤسسات التعليم العالي الخاص على التعامل مع المتغيرات المعاصرة من خلال تطوير كثير من أنظمته تحقيقاً للتميز والتوافق مع منطلبات التتمية.

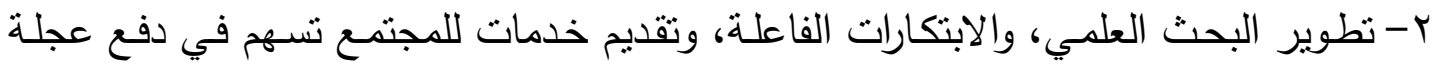
التنمية للوصول إلى المجتمع المعرفي.

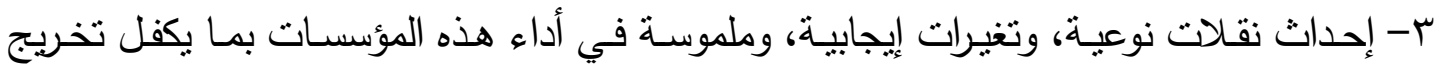
الكفاءات البشرية المؤهلة لسوق العمل والقادرة على تحقيق الريادة والمنافسة عالميًا.

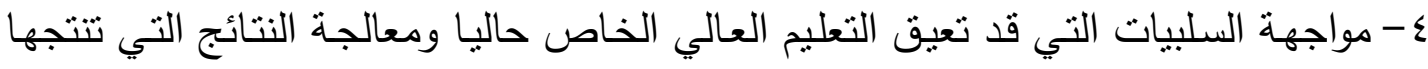
هذه السلبيات مستقبلاً. ه- اقتراح إجراءات تطبيقية لتلافي القصور في نظام التعليم العالي الخاص والتي تتمثل في عدم تحقيق بعض أهدافه، التجهيزات التعليمية، الكفاءة البشرية، نظام القبول. ث- - م- إجراءات التصور: لتحقيق أهداف التصور المقترح يتطلب ذلك مجموعة من الإجراءات والمتطلبات من نظام التعليم العالي الخاص تهدف إلى تطوير كافة عناصر المنظومة التعليمية، وتتضمن هذه

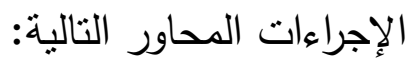




$$
\begin{aligned}
& \text { ـ أهداف الجامعات الخاصة. } \\
& \text { • الهيكل الإداري. } \\
& \text { • إجراءات إدارية حكومية. } \\
& \text { - ن نظام القبول. }
\end{aligned}
$$

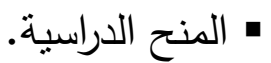

$$
\begin{aligned}
& \text { ه أعضاء هيئة التدريس. } \\
& \text { • نظام الاستقطاب والسعودة. } \\
& \text { - المقررات والتخصصات العلمية. } \\
& \text { ه الإمكانات التجهيزية. } \\
& \text { • - الخربجون. }
\end{aligned}
$$

أولاً: أهداف مؤسسات التعليم العالي الخاص:

أهداف مؤسسات التعليم العالي الخاص من أهم القضايا التي تثار حولها الثكوك التهاهي

في مدى جدواها وتطبيقها بفاعلية في التعليم؛ حيث يشير واقع بعض مؤسسـات التعليم العـالي الخاص عن قصسورها في تحقيق أهدافها المعلنة. ومن خـلال هذا التصسور ينبغي مراعـاة بعض النقاط المههـة عندـ وضـع أهداف التعليم العـالي الخـاص لمواكبـة المتغيرات

$$
\text { العصرية على النحو التالي: }
$$

• يراعى عند وضـع الأهداف إكسـاب الطلاب مهارات العمل والإنتاج المعاصـرة مثل (إتقان اللغــة الإنجليزبـة، ومهارة التعامـل مـع الكمبيـوتر وشبكة الانترنـت وذلك لتحقيـق الكفـاءة للخريجين.

الاهتمام بالبحث العلمي وخدمة المجتمع وذلك من خـلال تأسيس مركز بحثي في التعليم العالي الخاص لتحليل مشكلاته وأوضاعه واقتراح الحلول وتقديمه لسعادة مستشار مشرف العام على التعليم العالي الخاص. التركيز على إعادة صياغة الأهداف بما يتتاسب مع متغيرات العصر بحيث يتضمن الهدف من بنائها استحداث كليات تخصصية جديدة لا تتوفر في الحكومي. " تحديد سقف عالي من التمييز الأكاديمي يجب أن تصل إليه المؤسسة، وذلك يتطلب إسناد مهمة تصميم نظام الجامعة وبرامجها الأكاديمية لجهة خبيرة تتحقق لها هذا التطلع. الاهتمام بالتعليم المستمر والتعليم التعاوني والتطوير المهني لتحقيق التمايز في التعليم. 
يتطلب تحقيق الأهداف مساهمة الهيكل الإداري والتنظيمي على النحو التالي:

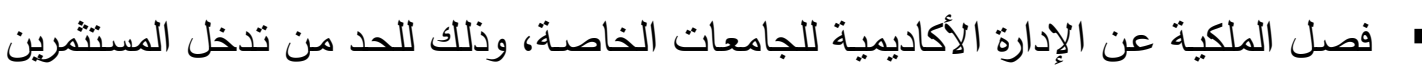
في الكثير من مجريات الأمور مما يعوق رفع كفاءتها الذاتية.

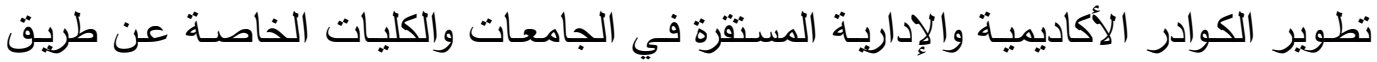
الابتعاث وتوفير المنح الدراسية. التوسع في إنثاء مؤسسات للتعليم العالي الخاص دون الجامعي لأن مخرجاته مطلوبة بشدة في عالم الإنتاج، وأن يراعى استحداث جامعات وكليات متتوعة تحقق التكامل والتمايز . تضمين العقود شروط جزائية تحدد حقوق وواجبات الطرفين لضمان استمرارية العلاقة التعاقدية. عند شغل الوظائف لابد من تحديد الوظيفة ويكون هناك وصف وظيفي لها. سد الاحتباج للوظائف الإدارية عن طريق الاستفادة من قوائم طالب العمل سواء في الخدمة المدنية أو صندوق الموارد البشرية.

تحديد أسلوب تعيين رؤساء هذه الجامعات ووضع معايير للاختيار أو التجديد.

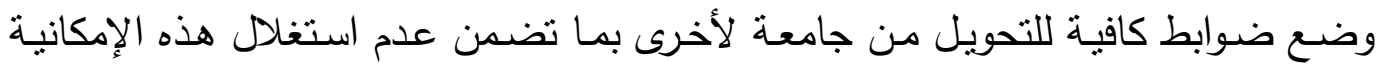
لالتهرب من التقييم الجامعي. الاهتمـام بتقنيـة المعلومـات والاتصـالات وأن نستخدم إدارة الجامعـة نظسام معلومـات إداريـة متكاملة لتواكب بيئة الثقنية العالمية المتغيرة. إنشاء وحدة متخصصة للتطوير والتدريب تهتم بتطوير القيادات الإدارية والكوادر الإدارية

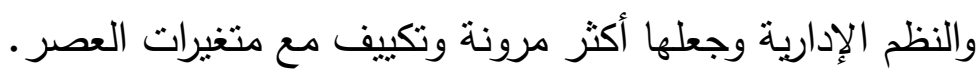
عمل حملات توعية تبين وظائف الجامعات الخاصة ودورها في المجتمع وأن هذا الدور لا يقتصر

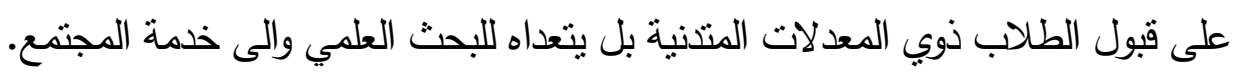
الاهتمام بإيجاد الجامعات وسائل لتقييم أدائها (رقابة ذاتية).

ثالثًا: إجراءات إدارية ذات الصلة بأجهادة حكومية: ربط الموافقة على التعاقد من الخـارج للكليات الخاصـة بإفادة الجهات الحكة الحكوميـة المعنيـة

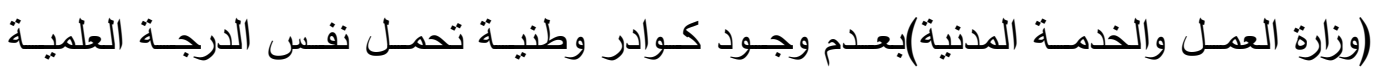
والتخصص المطلوب للتعاقد عليه 


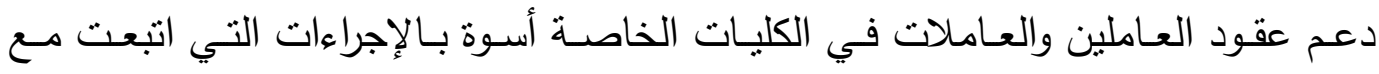

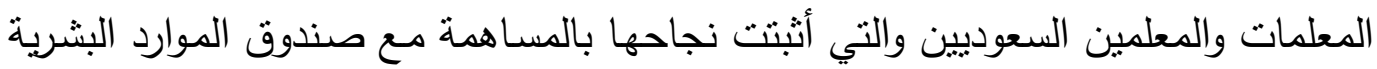
في هذا الجانب.

أن يتضمن طلب الترخيص المبدئي خطة حول احتياج الكليات من الكفاءات ولا يعطي ترخيص مبئي إلا بعد نوظيف عدد من المعيدين وإعطائهم منح ابتعاث.

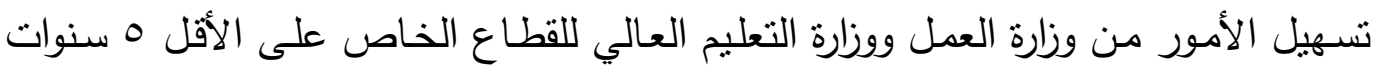

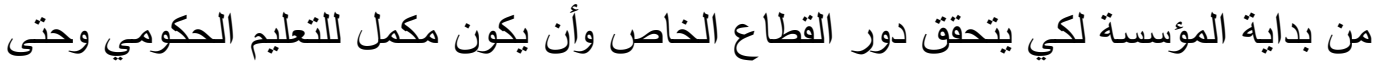
يتمكن المستثمرين من توسيع النطاق الجغرافي لإنشائها بحيث لا تتمركز في المدن الكبيرة

إثتراف التعليم العالي الخاص لهذه المؤسسات على أن يكون هناك يوم على غرار يوم

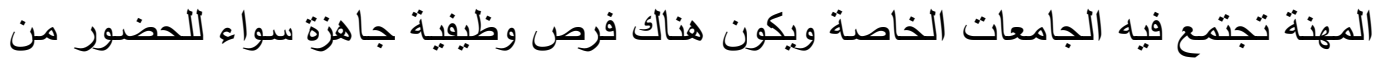
خريجي البعثات أو المتقاعدين تحصل المقابلات بدل البوابات الالكترونية بساعد ذللك على هلى

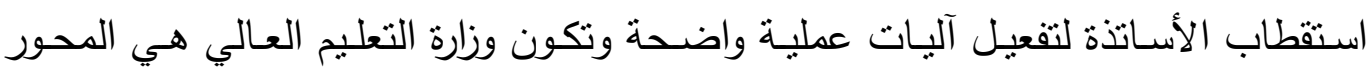
لإنجاح هذا اليوم الإنام ضرورة الاستفادة من خريجي بعثة خادم الحرمين الثريفين وذلك عن طريق استحداث قاعدة

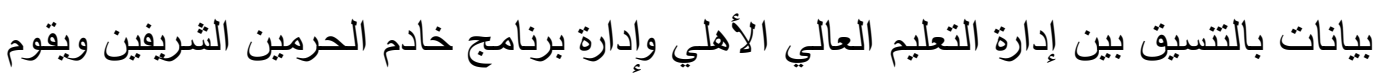

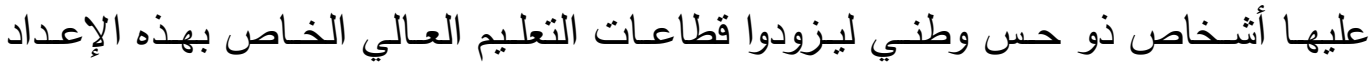
وبسيرهم الذاتية.

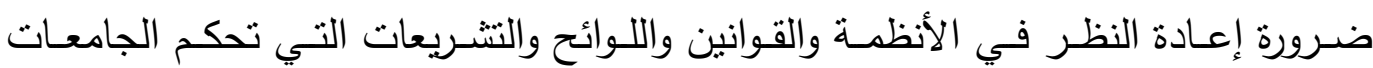
والكليات الأهلية لجعلها أكثر مرونة ومواكبة للواقع حتى تسهل الأمور لهذه المؤسسات.

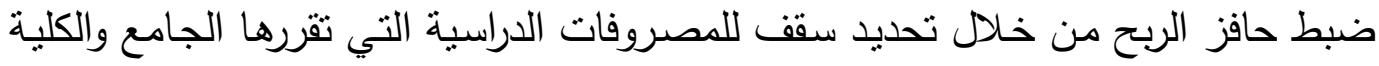
لكل تخصص أو برنامج. بث التتافس بين المستثرين بما ينتج عنه تخفيض التكلفة وتحسين النوعية بما يعود بالفائدة

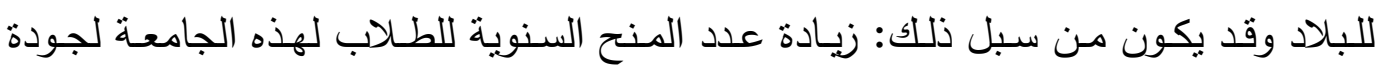

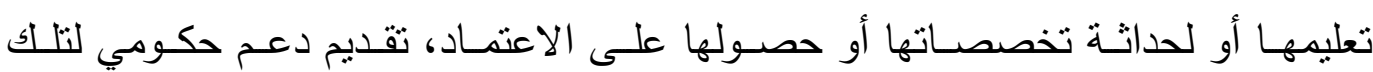

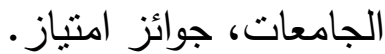

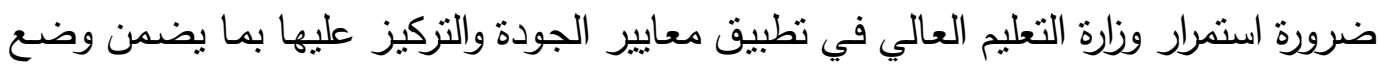
الجودة والاعتماد في التعليم العالي الخاص وجعل هذه المؤسسات محل نقة المجتمع. 
إلزام الجامعات والكليات الخاصـة بتعيين مستشـار أكاديمي لكل كلية على حده يختص

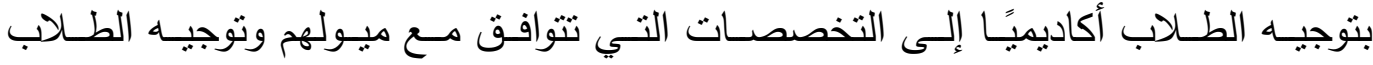

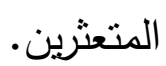

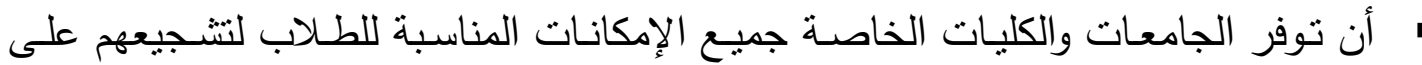
الدراسة في مناخ تعليمي مناسب. أن يتم تكليف لجنة بفرز طلبات القبول للطلاب على أن يتم قبولهم بناء على المعدلات الأعلى وليس بناء على أسبقية الحجز . "تقليص التفاوت في درجات القبول في الجامعات الخاصة والحكومية بنسب مقبولة. • أن برتبط قبول الطلاب بالقدرة الاستبعابية المقررة لكل كلية والقدرات الخاصة بالطلبة بما يتوافق ومنطلبات الدراسة التي تحددها الجامعة وذلك عن طريق لجنة محايدة متخصصة. خامسًا: المنح الدراسية للطلاب: لكي يكون قرار المنح مرتبطاً بجودة التعليم ولكي يكون محفزاً على تميز مؤسسات الطيات

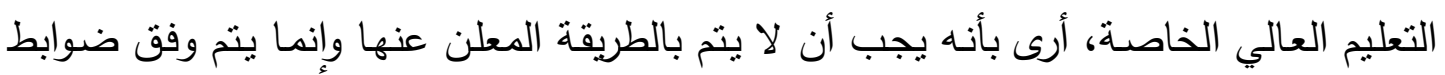
من أهمها مايلي: • أولاً: تقدم المنح لمن تستقطبه الكلية الخاصة بالرغم من إمكانية قبوله في الكلية الحكومية

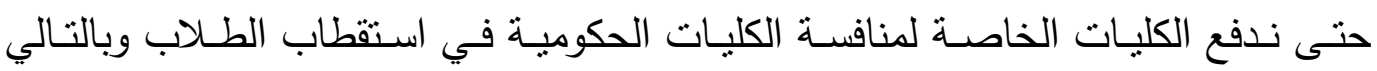

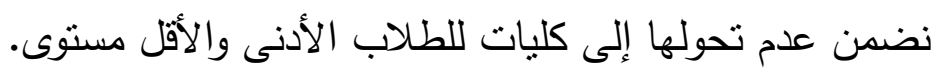

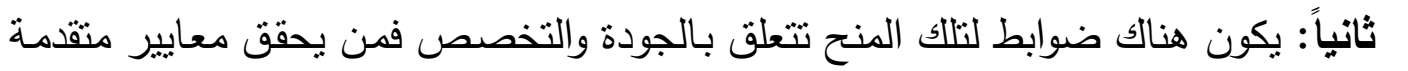

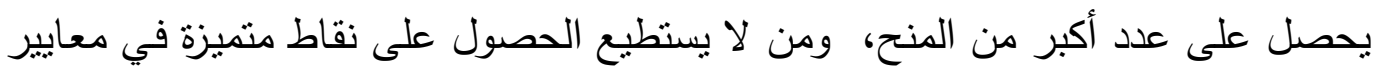

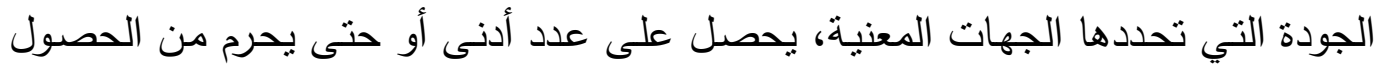

$$
\text { على منح دراسية. }
$$

ثالثاً: وحتى تربط تلك المنح باحتباجات سوق العمل يمكن أن تمنح الكلية التي يحصل

$$
\begin{aligned}
& \text { خريجوها على وظائف بشكل أسرع على عدد منح أكبر . } \\
& \text { سادسًا: أعضاء هيئة التدريس: }
\end{aligned}
$$


إعادة النظر في نسبة حملة الدكتوراه بالنسبة للتعليم العالي الخاص حيث أن الباحثانين عن

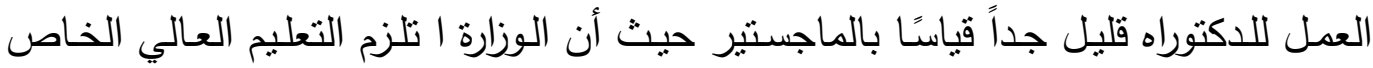
بتوفير نسبة حملة الدكتوراه مرتفعة مما يعوق توفرها.

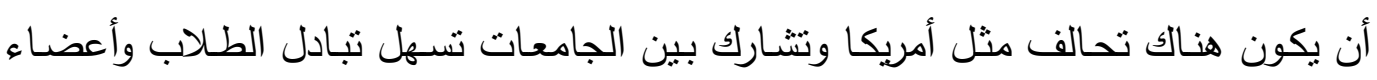

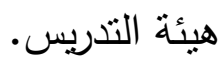
تفعيل دور الثراكة بين التعليم العالي الخاص والحكومي وأن يكون قولاً وفعلاً لأنهم كلهم في نفس الموكب وذللك عن طريق تسهيل إجراءات الندب والتعاقد للأكاديميين والقيادات في لفي الجامعات الحكومية وذلك لتبادل الخبرات. تبسيط إجراءات التقديم وإعادة النظر في المعايير العالميـة المعتمدة مثنل خبرات طويلـة ومهارات يمكن اكتسابها في العمل. إناحـة الفرصـة لأعضـاء هيئة التدريس بالتمتع بالحقوق الأكاديمية للعاملين في الجامعات الحكومية ( التفرغ العلمي، البحوث العلمية). تفعيل دور أعضاء هيئة التدريس في اتخاذ القرارات الخاصة بكلياتهم بما يكفل جودة العملية

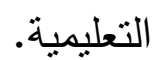

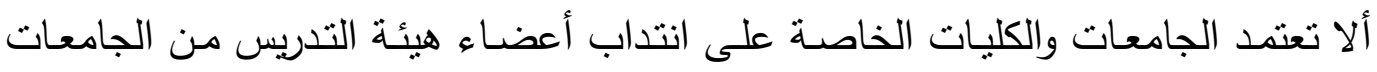

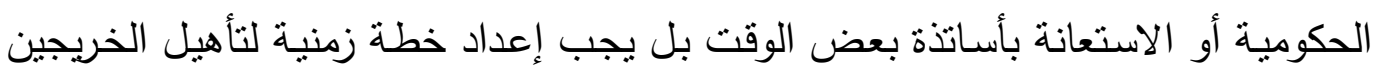

$$
\text { وخصوصًا في التخصصات الحديثة. }
$$

إناحـة الفرصـة للأعضـاء العـاملين للمشـاركة في المؤتمرات والملتقيـات العلميـة العالميـة وتسهيل اثتراكهم فيها وينطلب ذللك رصد الميزانيات لعقد وحضور المؤتمرات.

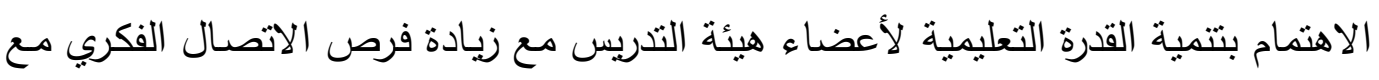
أعضاء هيئة التدريس بالجامعات الأجنبية. سابعا: نظام الاستقطاب والسعودة:

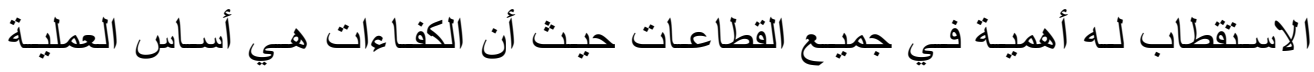
التعليمية في أي مؤسسه والتي تحدد مدى جودة هذه العملية.

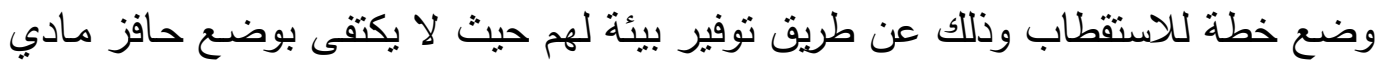

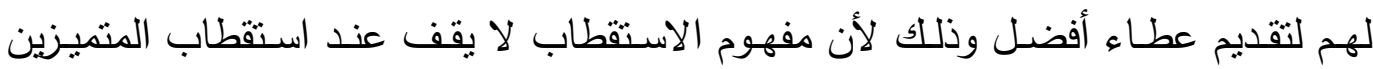
يتعدى لتهيئة بيئة مناسبة لهؤلاء للإبداع. 
تحديد معايير واضحة لآلية الاستقطاب على أن تكون واضحة ومحددة يمكن الرجوع إليها وتوفر الحيادية في عمليه الاستقطاب.

وضع آلية تحقق صفة الأمن الوظيفي لاستقطاب الكفاءات الوطنية للعمل في الجامعات

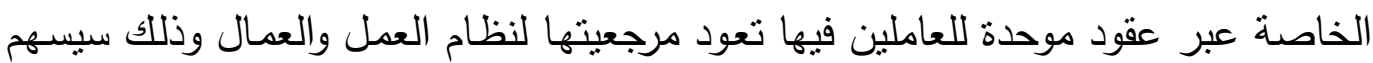

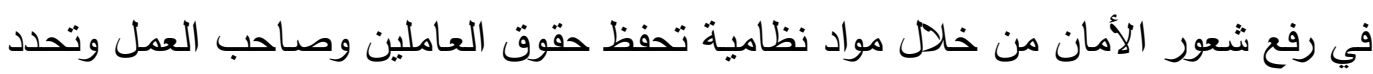
واجباتهم والنص عليها صراحة في العقد الموحد بالإضافة إلى الالتزام من قبل الجامعات

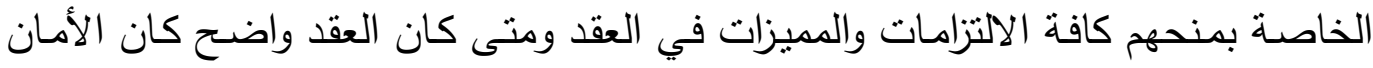
متحقق.

لابـد مـن مشـاركة الجهات المعنيـة بحمـلات توعويـة موجهـة لكافـة الثـرائح لتغيير نقافـة

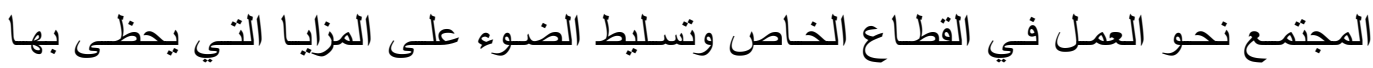

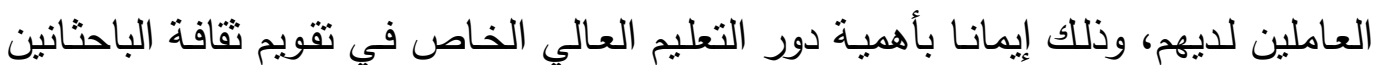
عن العمل للاتجاه للقطاع الخاص. رفع رواتب الأكاديميين في القطاع الخاص بالأتعاون مـع الموارد البشرية وتقليل الفرق بين

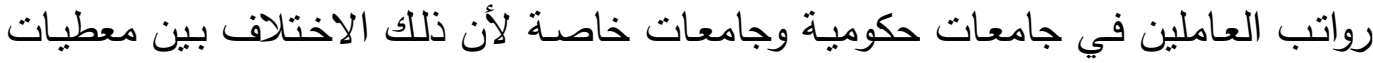

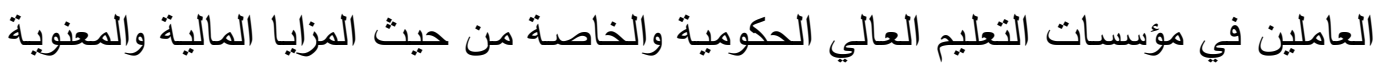

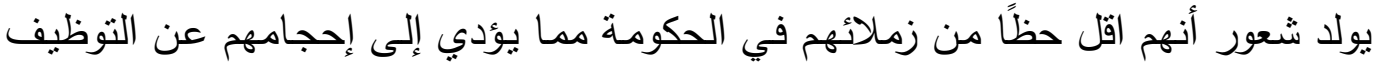

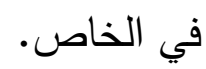

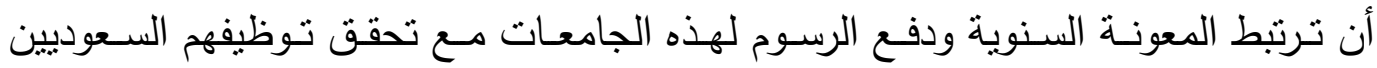

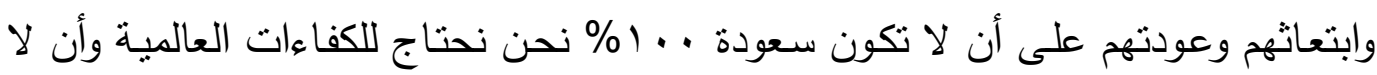
يكون التوطين على حساب الجودة حيث يجب أن أن نحرص في في قضية التوطين على قضية

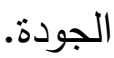
تخصيص الوزارة . .0 منحـة للكليات والجامعـات الخاصـة في الابتعـاث الخـارجي وهذا سيجعلهم يعملون لتلك الجهات ويكون هنالك ولاء لتنالك الجهات. تعيين المبتعثين على برنامج خادم الحرمين الثريفين في الابتعاث الخارجي بعد حصولهات لأهم

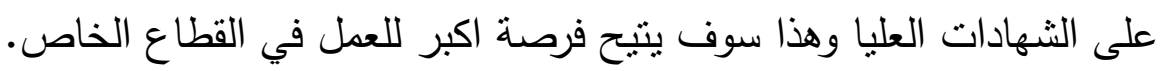

\section{الاستفادة من المتقاعدين وذلك عن طريق:}

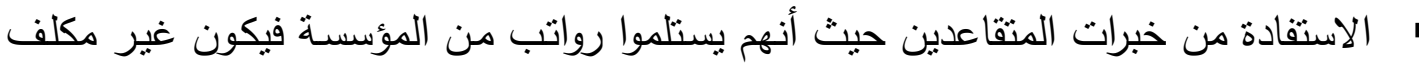

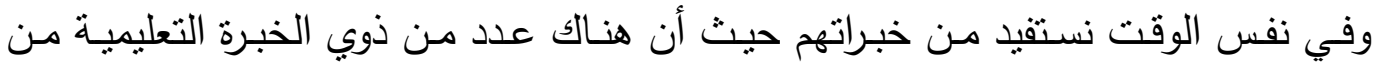
المتقاعدين من الجهات الحكومية. 
ضـرورة أن تقوم وزارة التعليم العـالي الخـاص بوضـع إستراتيجية مستقبلية للاستفادة مسن الخبرات التعليمية من المقبلين للتقاعد في القطاع الخاص في توظيف هؤلاء الخريجين

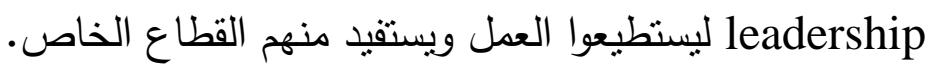
ه إنثاء هيئة للمنقاعدين خاصة بالتعليم العالي حتى تسمح للكليات والجامعات التعاقد معهم.

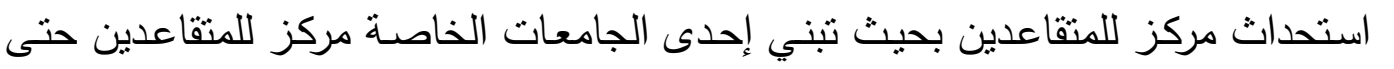
يستقيدوا منهم جميع الجامعات والكليات الخاصة. ثامنا: المقررات و التخصصات العلمية:

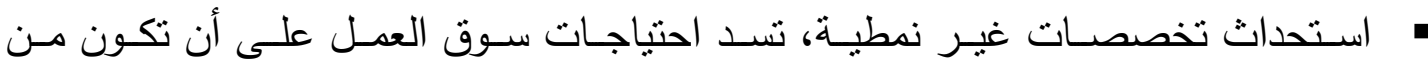
التخصصات التي لم بتطرق إليها الجامعات الحكومية حتى يكون بينهما تكامل، وذلك لتلبية منطلبات التتمية ومواكبة المتغيرات المعاصرة. الاهتمام بتدريب الطلاب من خلال برامج التعليم المشترك(التعاوني) وذلك عن طريق تعزيز الصلة بين هذه المؤسسات والقطاع الخاص لتأهيله للعمل بكفاءة.

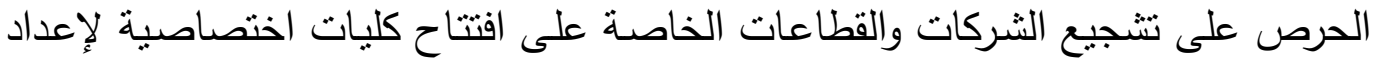
كوادرها وفنييها وتدريبهم مما يستدعي زيادة الاختصاصبين من القطاع الخاص كمدربين في بعض البرامج النطبيقية التي تحتاجها مجالات القطاع الخاص.

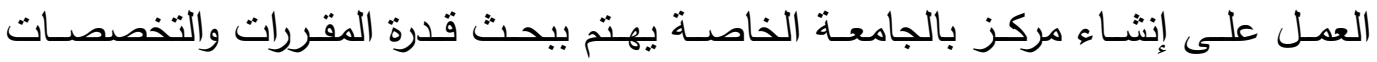
والأساليب وطرق التقويم على مواكبة المتغيرات وتكون مهمته معرفة مواطن الضعف والقوة في العملية التعليمية والعمل على علاجها إلى أقصى قدر مولى مدكن. تاسعا: المباني والتجهيزات الجامعية: توفير الأجهزة المنطورة اللازمة لعمليتي التعليم والتعلم مع ضرورة توفير الأدوات والخامات والأجهزة اللازمة للتنريب الميداني. مراعاة توفير جميع الإمكانات المادية والتجهيزات التعليمية من مختبرات وقاعات وملاعب ومعامل وغيرها من التجهيزات التي تدل على بيئة تعليمية جدية.

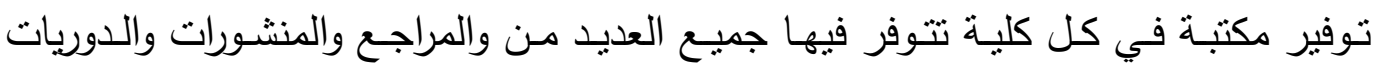

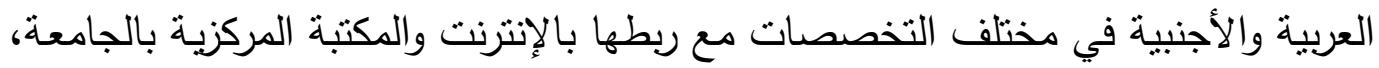

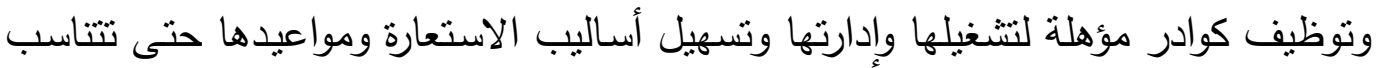

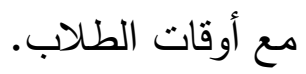




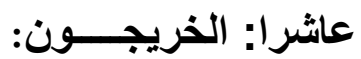

• الاستفادة من مخرجات التعليم العالي الخاص المتميزة بإتاحة الفرصـة لهم للحصول على ملى درجات علميه عاليه بالابتعاث مع شرط العمل لديهم لفترات زمنيه محدودة. • أن تتشئ كل جامعة وكلية خاصة وحدة لخريجيها تقوم بمتابعتهم بعد التخرج ومدى انجازهم

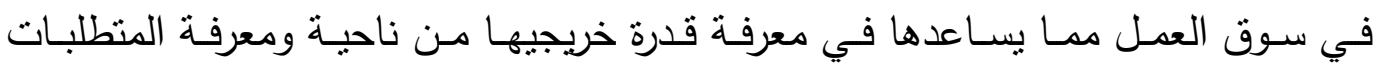
المجتمعية الحالية والمستقبلية من ناحية أخرى.

\section{الفصل الخامس}

\section{خلاصة النتائج و التوصيات و المقترحات}

$$
\text { ملخص نتائج البحث: }
$$

في ضوء النتائج السابقة التي استخلصت من البحث سنعرض أهم النقاط الجوهريـة في

$$
\text { نتائج البحث والتي بمكن تلخيصها باءلاتي: }
$$

• جـاءت درجـة الموافقة حول واقـع الممارسـات التطبيقيـة للخصخصـة في مؤسسـات التعليم العـالي في المملكـة العربيـة السعودية مسن وجهـه نظـر أعضـاء هيئة التدريس في كليـة

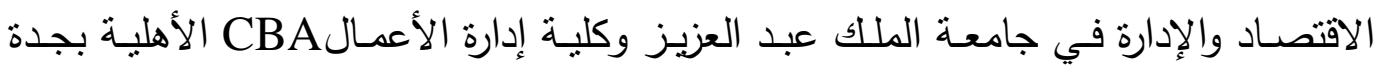
"أواقق" لكلاً منهما. • أظهرت نتائج البحث أن درجة الموافقة حول الإيجابيات التي تدعو للتوسع في الخصخصة

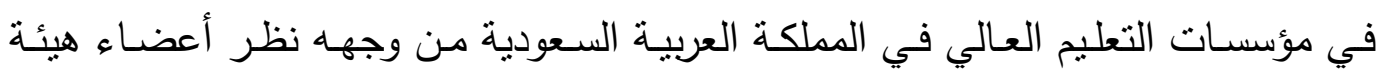

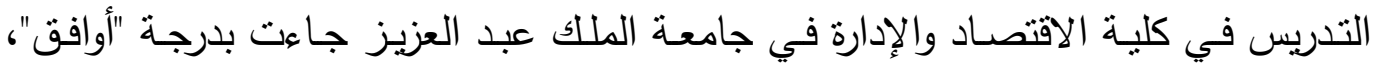
واختلفت من وجهة نظر أفراد العينة من أعضاء هيئة التذربس في كلية إدارة الأعمال

$$
\text { الأهلية ؛حيث جاءت بدرجة "أوافق بشدة". }
$$

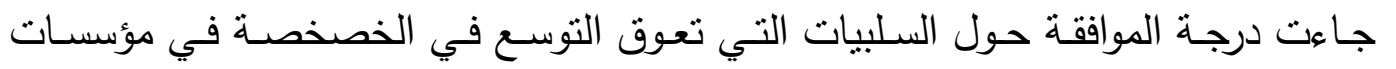
التعليم العالي في المملكة العربية السعودية من وجهه نظر أعضاء هيئة التدربس في كلية الاقتصاد والإدارة في جامعة الملك عبد العزيز بدرجة "أوافق"، واختلفت من وجهة نظر اعنة أفراد

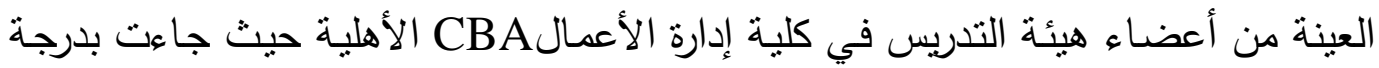

$$
\text { موافقة "محايد". }
$$

" جـاءت درجـة الموافقة حول الإجـراءات المقترح تطبيقها للخصخصـة في المملكة العربيـة السعودية من وجهه نظر أعضاء هيئة التذريس في كلية الاقتصاد والإدارة في جامعة الملك عبد العزبز وكلية إدارة الأعمال CBA الأهلية بجدة "أواقق" لكلاً منهما. 


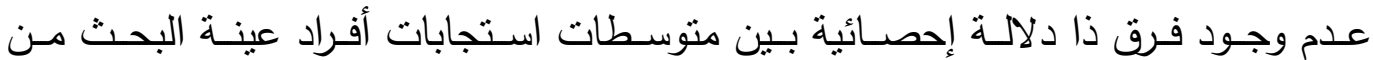

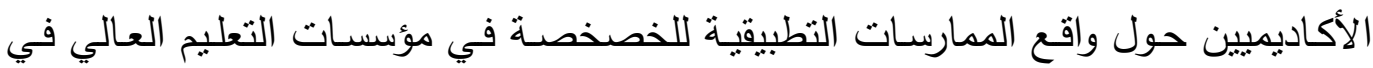
المملكة العربية السعودية تعزى لمتغير "نوع الجامعة". وجود فرق ذا دلالة إحصائية بين منوسطات استجابات أفرات الفراد عينة البحث من الأكاديميين

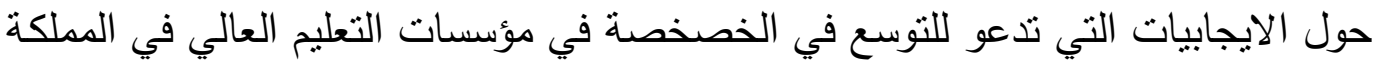

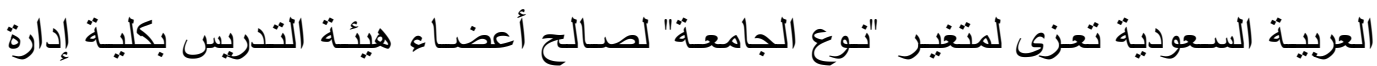

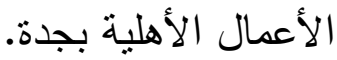
كما أظهرت نتائج البحث وجود فرق ذا دلالة إحصائية بين منوسطات استجابات أفراد عينة

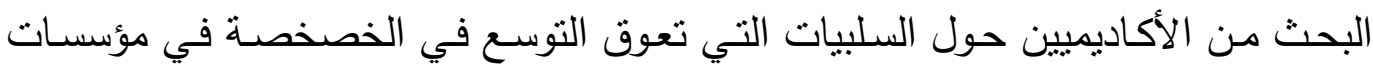

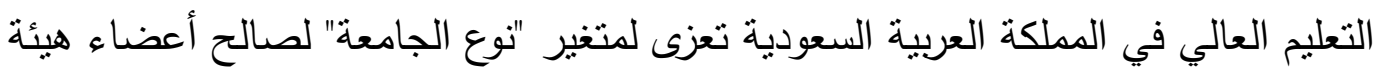

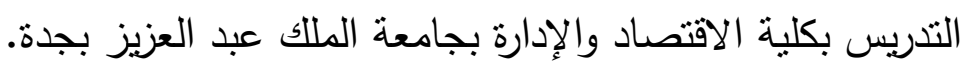

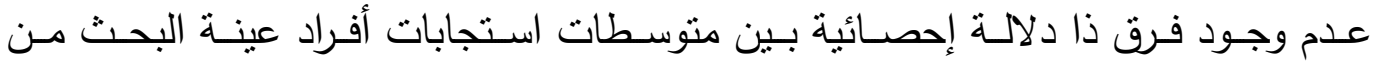

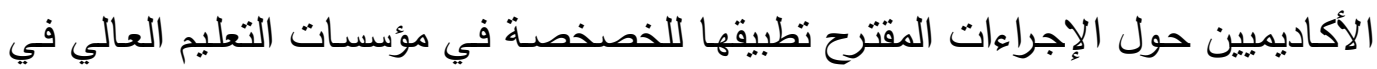

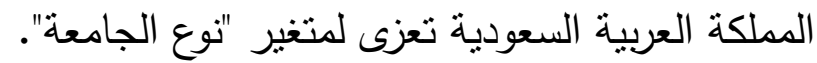

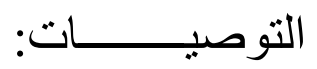
من نتائج البحث الحالي ومن الدراسات السابقة يمكن الخروج ببعض التوصيات التي تفيد مجال خصخصة التعليم العالي وهي كالتالي:

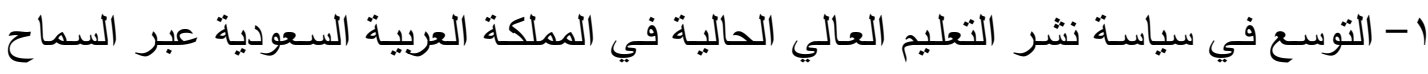

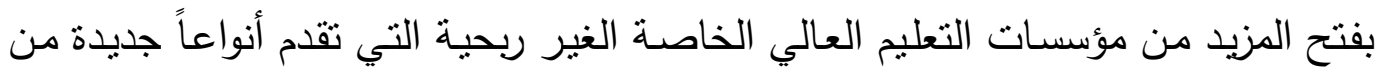

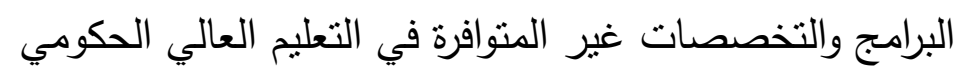
r- استمرار إنشراف الدولة على مؤسسات التعليم العالي الخاصة وتطبيق معايير الجودة حتى التى التئي

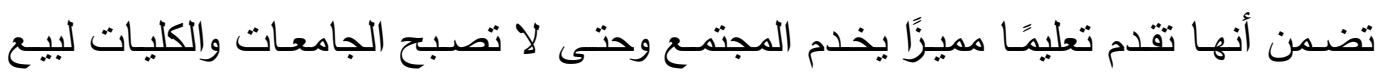
الثهادات لغير المؤهلين علميًا والقادرين ماديًا. r- الاعتدال في فرض الرسوم الجامعية في مؤسسات التعليم العالي الخاصة ومراعاة الظروف التران لجميع فئات المجتمع من مواطنين وغير المواطنين.

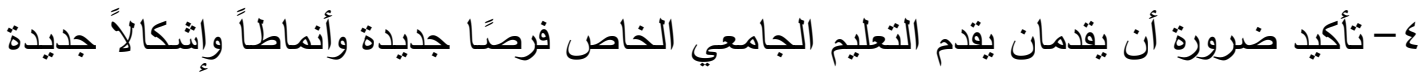

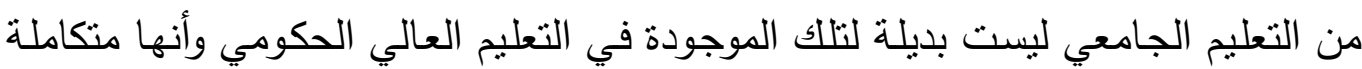
معها ورديفة لها. 
0- انشتراط وجود حد أدنى من الأكاديميين الدائمين ويستحسن أن يكون هناك حد عام على الكى مستوى المؤسسة ككل وحد خاص على مستوى التخصصات العلمية لكل التخصصات.

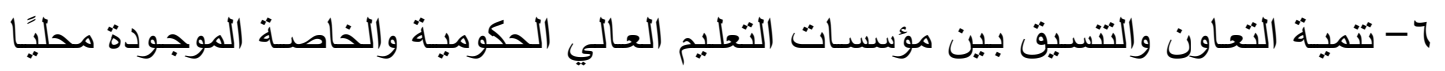

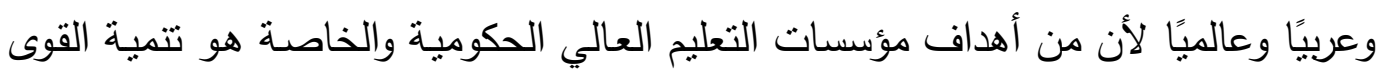

$$
\text { البشرية لمواجهة التحديات العربية والعالمية. }
$$

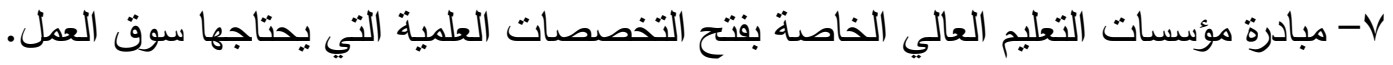

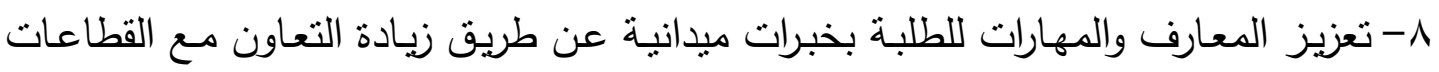

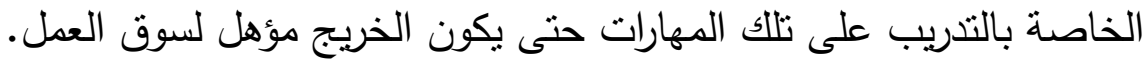

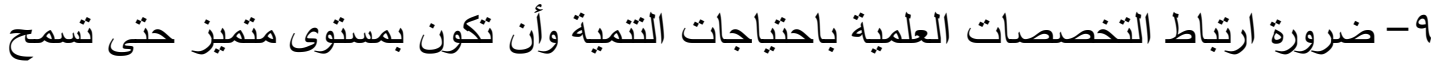
بممارسة العمل في الواقع العملي. • 1 - زيادة فاعلية التعليم العالي عبر وضع العمع نوع من أنواع المنافسة بين مؤسساته حول من بقدم أفضل مستوى للتعليم العالي.

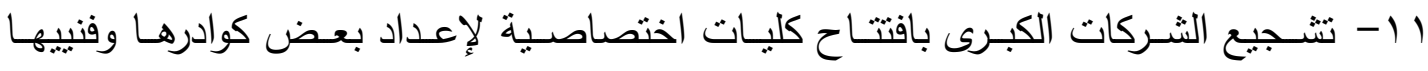

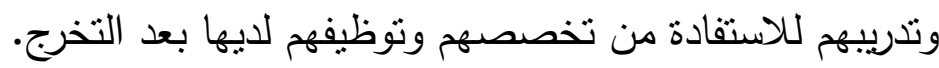

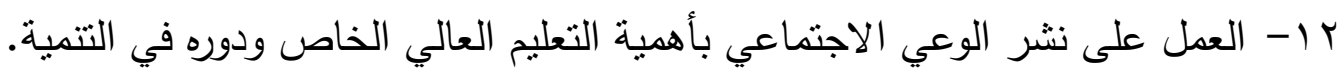

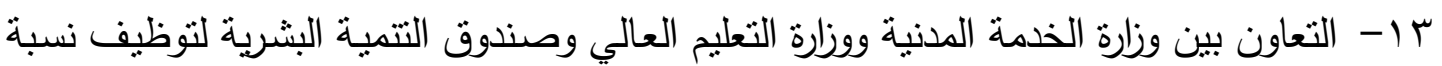
من الأكاديميين السعوديين مع توفير مقومات استمرارهم في تلك المؤسسات.

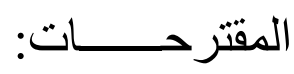

1- إجراء دراسة مماثلة عن خصخصة التعليم العالي في المملكة العربية السعودية يتم التركيز

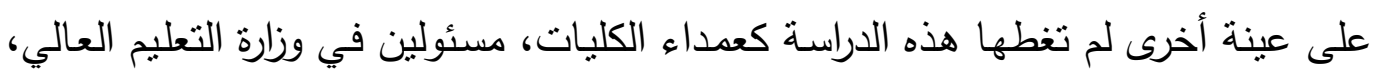

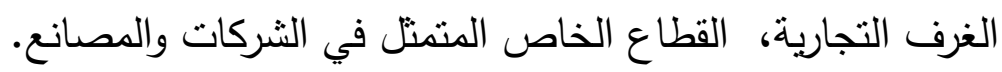
r- إجراء دراسات تحليلية مقارنة لتجارب الخصخصة العالمية لم تتتاولها هذه الدراسة كتجربة

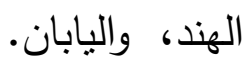
r- إجراء دراسات تقويمية عن دور الجامعات الخاصة في تلبية متطلبات التتمية وحاجات

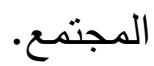

ع- إجراء دراسة عن طرق تفعيل التعاون بين مؤسسات التعليم العالي الخاص وقطاع الأعمال. ه- إجراء دراسات عن التحديات التي تواجها الخصخصـة في الدول العربية عامـة والدول الخليجية خاصة צ- إجراء دراسة عن مدى إسهام الجامعات الخاصة في نمو البحث العلمي وكيفية زيادة فاعليته. 


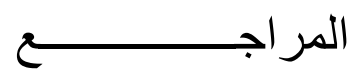

\section{أولاً المراجع العربية:}

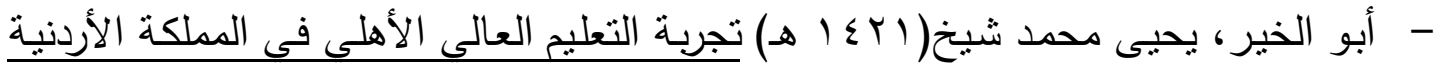

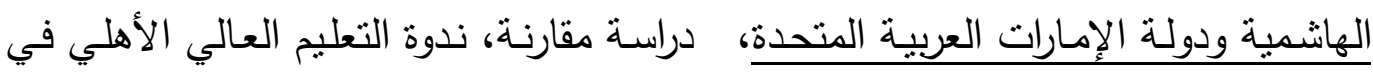
المملكة، كلية التربية، جامعة الملك سعود: الرياض.

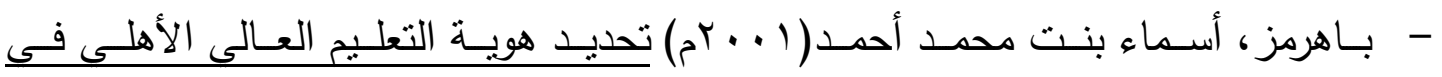

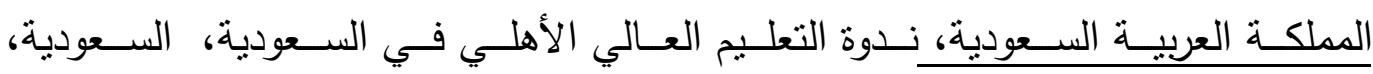

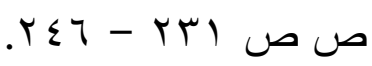

- البدر، حمود عبدالعزيز (1 . بrم) تجارب بعض الدول العبية والإسلامية والأجنبية، ندوة

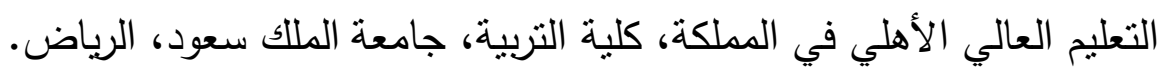

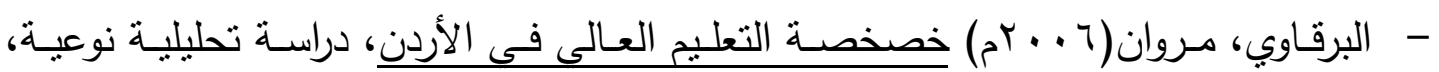
أطروحة دكتوراه غير منشورة، جامعة اليرموك: الأردن.

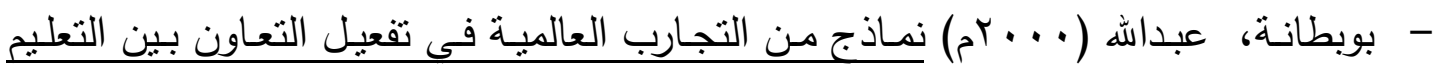

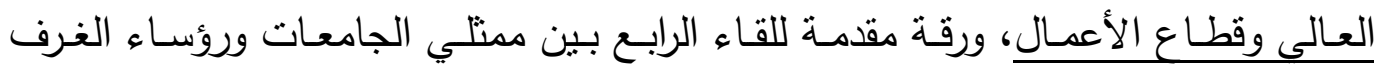

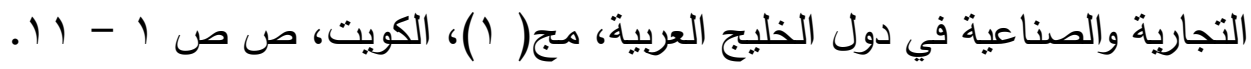

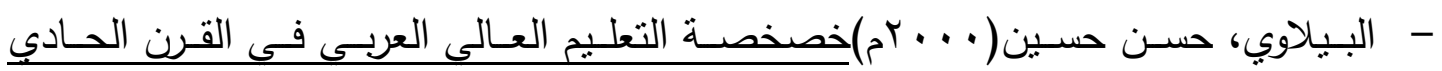
والعشرين: التحديات والاستجابات، ورقة عمل مقدمة للمؤتمر التزبوي الثاني، الإمارات.

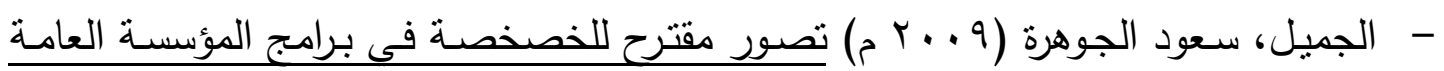

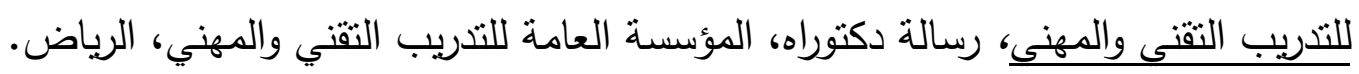

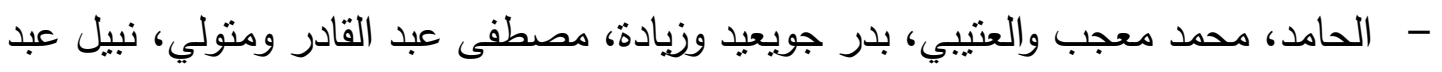

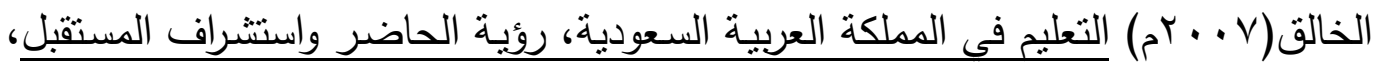

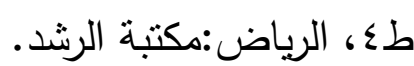

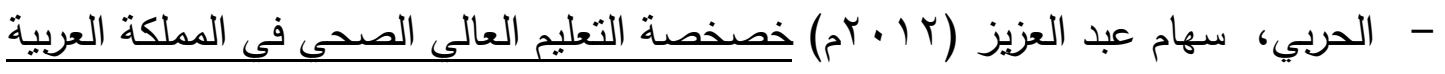
السـودية وأثره على تلبيـة الاحتياجـات مـن الموارد البشرية، كلية التربيـة، جامعـة طيبـة: 
- حسان، حسن محمد ومجاهد، محمد عطوة وعلي، فكري محمد (1 . . r م)التعليم الجامعى الخاص النطور والمستقبل، الأزاريطة: دار الجامعة الجديدة.

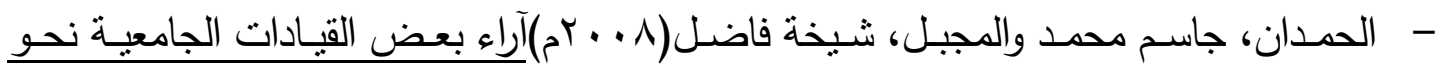

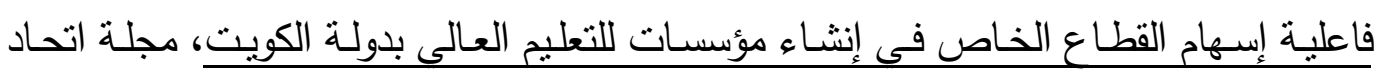

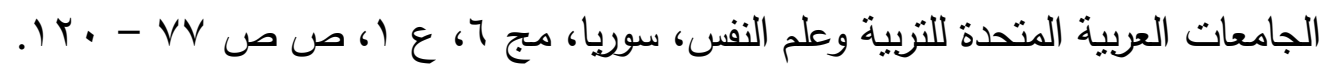

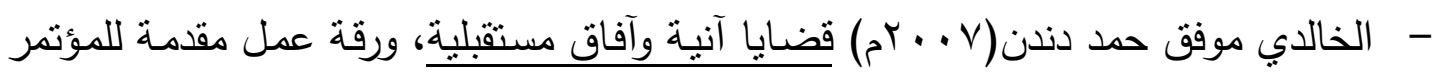

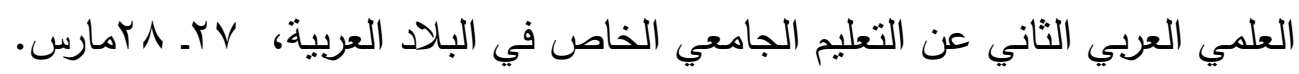

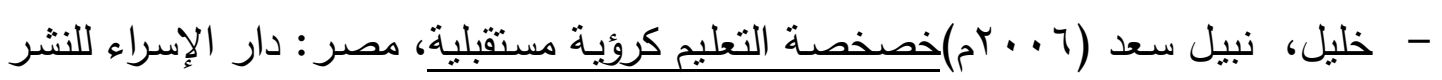
والطبع والتوزيع.

- الرباعي، زهير علي(1) (1 بم) خصخصة التعليم الجامعى في الأردن، دراسة نقدية، مجلة

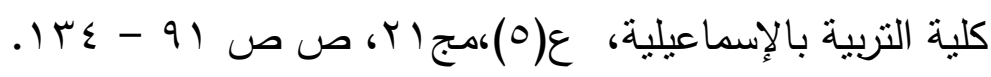

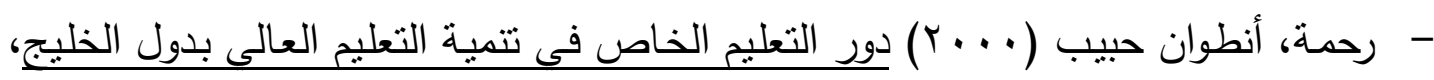
بحث مقدم للمؤتمر التزبوي الثاني، جامعة عمان: مسقط.

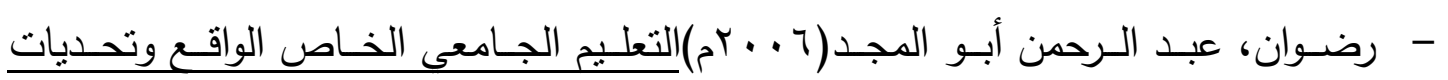

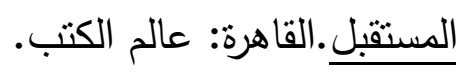

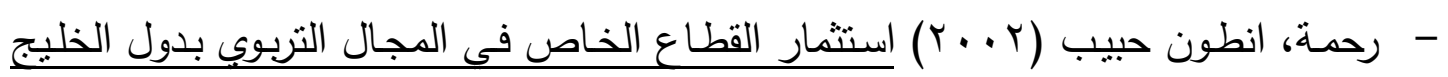
العربي، رؤى مستقبلية، مكتب التربية العربي لدول الخليج: الرياض.

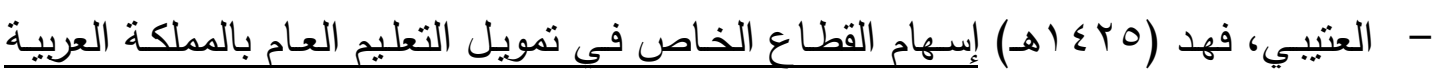
السعودية، أطروحة دكتوراه، كلية التربية، جامعة الملك سعود:الرياض.

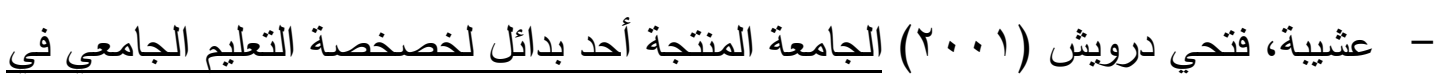

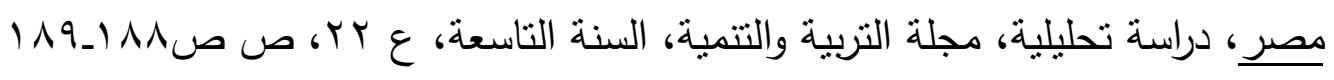

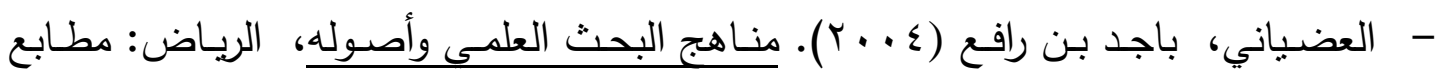
الجزيرة. 


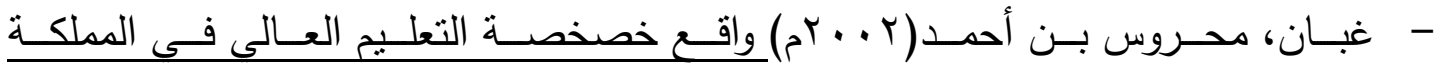

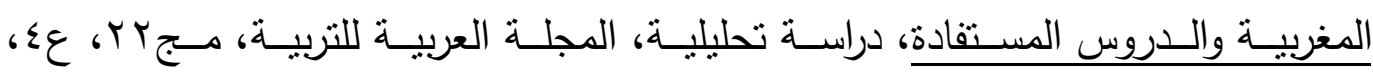

$$
\text { ص ص }
$$

- الغرفـة التجاريـة الصناعية بالرياض( ( + . rم) التعليم الجـامعي الأهلي أهميته، تخطيطه، ضوابطه، ورقة عمل مقدمة إلى ندوة التعليم الأهلي في المملكة، كلية التربية، جامعة الملك

$$
\text { سعود، }
$$

- الغيثي، عبداله مبارك( · . . rم)التعليم العالي الخاص: خصوصيته، حجمه، أنواعـ، أسباب

نموه، علاقته بالدولة، مجلة الدراسات والبحوث التربوية، ع 0 ا.

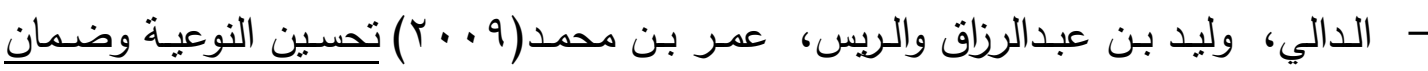
الجودة في مؤسسات التعليم العالي السعودية الأهلية، ورقة عمل مقدمة للمؤتمر الإقليمي

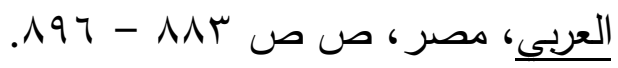

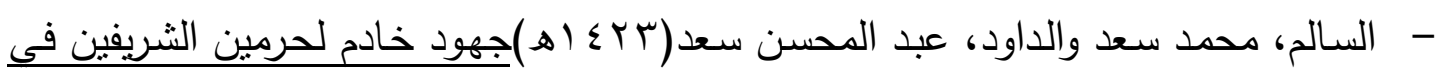

تطوير التعليم العالي، رؤية مستقبلية، الرياض:مكتبة الملك فهد.

- سعد نجابر عبد الله( . . . ب)التعليم الجامعي في اليمن ودوره في خدمة التمية، دراسة مقدمه

$$
\text { إلى مؤتمر التعليم العالي الأهلي، صنعاء، · ب مايو. ا يوليو. }
$$

- السلطان، خالد صالح وباشيخ، عبد الرحمن محمد والحمود، محمد عبد الله( ( . . rم) ندوة

التعليم العالي الأهلي في المملكة، كلية التربية، جامعة الملك سعود، الرياض - فرجاني، نـادر (991 (م) مساهمة التعليم العالي في التتمية في البلدان العربية، المؤتمر الإقليمي العربي حول التعليم العالي، لبنان: بيروت، بـ0 مارس.

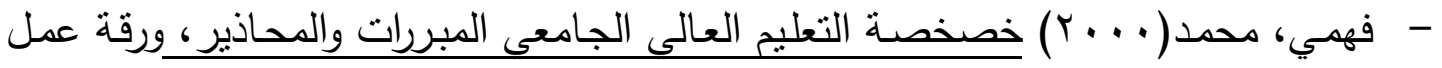
مقدمة للمؤتمر التربوي الثاني، عمان: مسقط. - القحطاني، محمد(1 . . r) الاستثمارات المستقبلية للقطاع الخاص في التعليم العام في المملكة العربية السعودية، أطروحة دكتوراه غير منشورة، جامعة أم القرى: مكة المكرمة.

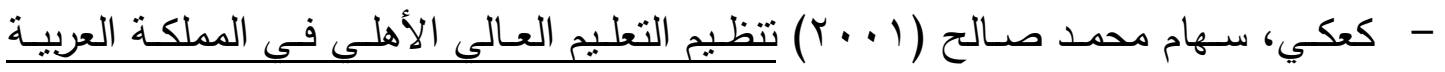
السعودية والاستفادة من الاتجاهات التتظيمية العالمية المعاصرة، ندوة التعليم العالي الأهلي

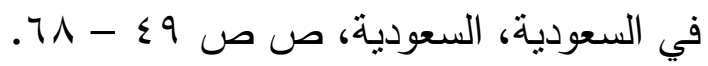


- المـانع، عزيـزة (r . . rم) اتجاهـات القيـادة التربويـة في المملكـة العربيـة السـعودية نحسو

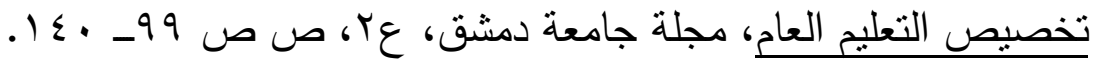

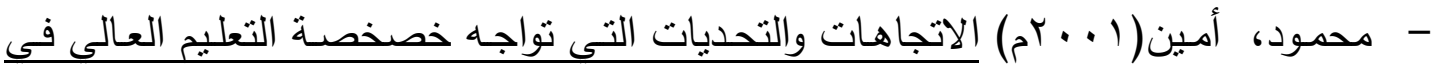
العالم العربي، ورقة عمل مقدمة للمؤتمر الدولي الحادي والعشرون، عمان:مسقط. - المطرفي، شجاع علي( . . . F م)مدى مساهمة القطاع الخاص في التعليم العالى بالمملكة العربيـة السـعودية في ضـوء المتغيرات المجتمعيـة والاتجاهـات العالميـة المعاصـرة، رسـالة دكتوراه غير منشورة، كلية التربية، جامعة القاهرة، فرع بني سويف. - المطرودي، حمود عبد العزيز (־؟ (اه) التوظيف في القطاع الخاص ومخرجات التعليم العالى في المملكة العربية السعودية، جامعة المللك سعود، إدارة الإعمال، الرياض

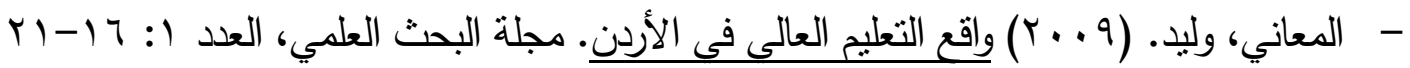

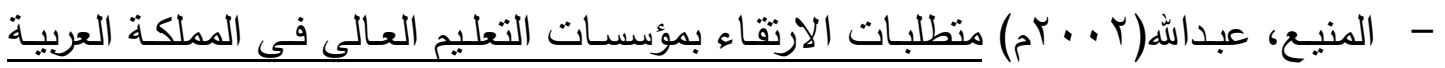
السعودية من منظور مستقبلى، ورقة عمل مقدمة لندوة وزارة التخطيط، الاقتصاد السعودي، الرياض، المنعقد في الفترة من 9 ا-بr ب أكتوبر • - المنيع، محمد عبداله (د.ت) تظوير مؤسسات التعليم العالى الحكومية والأهلية في المملكة العبية السعودية باستخدام نظام التعليم المفتوح والتعليم عن بعد، بحث مقدم من الجامعة

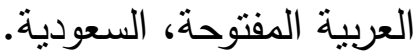

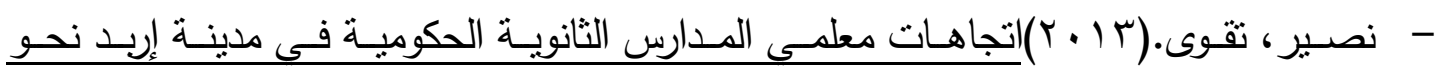

خصخصة التعليم العام في الأردن، رسالة ماجسنير غير منشورة، جامعة اليرموك الأردنية.

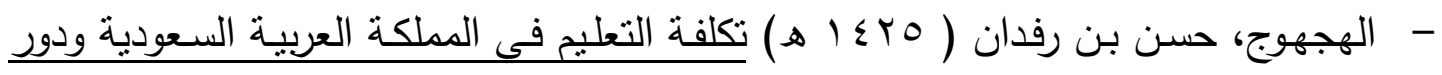

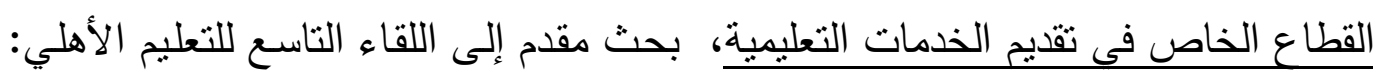

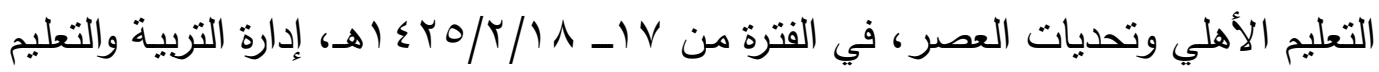
للبنين بمحافظة الإحساء، الإحساء.

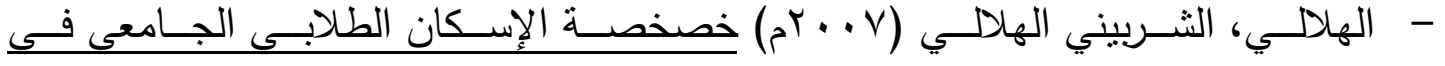

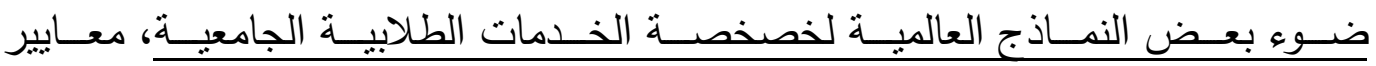

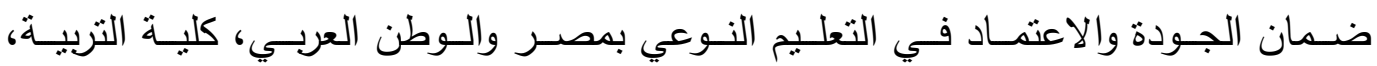
المنصورة، 1 إ- r ا ابريل. 
- Bajaj Shammi, (2012) Privatization of Higher Education- A Boon or a Ban. International Journal of Research in Economics \& Social Sciences, Volume 2, Issue 7, ISSN: 2249-7382, http://www.euroasiapub.org

- Clark, Robert Dean(2002)Components of selected publicprivate partnerships to build new school in California: Ed.D degree, university of Laverne

- Holzhacker,DenildeOliveira,Chornoivan,Yazilitas,Demet,(2009)

Privatization in Higher Education: Cross-Country Analysis of Trends, Policies, Problems, and Solutions,Institute for higher education policy.

- Kevin ,Dougherty (2004)Financing Higher Education In Theunited States: Structure, Trends, and Issues. Associate Professor of Higher Education. Columbia University

- Lee,Joham (2003) Higher Education and Privatization, NEA National Education Association.

- L.Geiger, Roger and E. Heller, Donald (2011) Financial Trends in Higher Education: The United State. Director, Professor and Senior Scientist. The Pennsylvania State University

- Marcos Francisco (2003) Privatizing Higher Education In Spain:: Market Developments and Government Policy. IE Working Paper, WP13/03, I.S.S.N: 1579-4873.

- Mary,McAleese. Bladh,Agneta.Berger,Vincent et al(2013) High Level Group on the Modernisation of Higher Education" Report to the European Commission on Improving the quality of teaching and learning in Europe's higher education institutions.

- Merisotis, J (2002) A Strong Nation Through High Education. USA: Lumin Foundation

- Rober,C(1992),Earlly retirement>New York,Plnum Press 1992> 
- Seloamoney Palaniandy(2013) Are Students Our 'Customers'?: A Perspective on the Bureaucratic Implications of 'Student-Customer' Concept in Malaysian Higher Learning Institutions. The Asian Conference on Education 2013

- Suresh, Babu (2011)G.S.Privatization of Higher Education in India: Challenges of Social Equality.Asst. Professor, Dept. of Sociology.University of Jammu, Jammu and Kashmir.

- Todd, Leach(2008) The impact of for-profit privatization on higher education in the state of Massachusetts. Doctor of Philosophy.Northeastern University

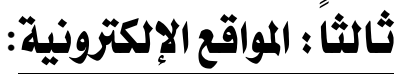

- برامج آفاق التتفيذية(Y بـ () الخطة المستقبلية للتعليم الجامعى في المملكة العربية السعودية

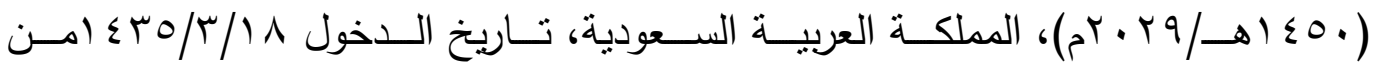
http://aafaq.mohe.gov.sa/default.aspx موقع - حسن بربورة وحكيم، شويحة (· ( • م م) مناهج بحوث الإعلام، تاريخ الدخول بr ب ربيع

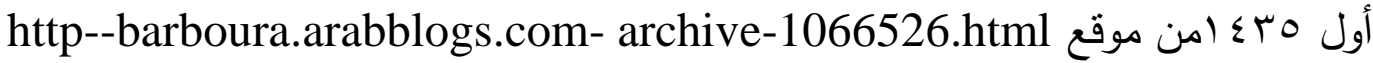

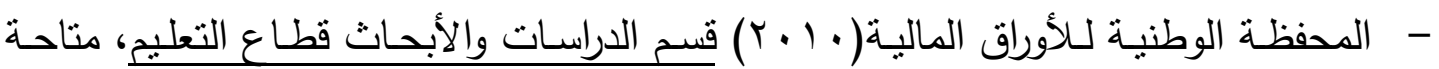
على الإنترنت: pdf. •tion_http://www.npsc.com.jo/files/Educa تاريخ الدخول

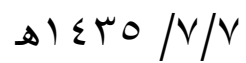

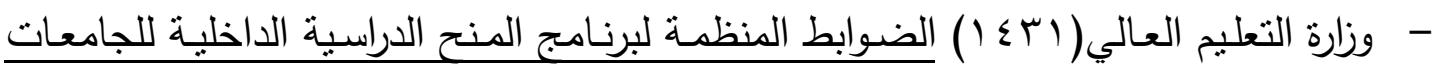

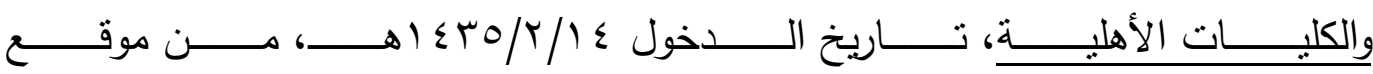
ault.aspxhttp://www.mohe.gov.sa/ar/def

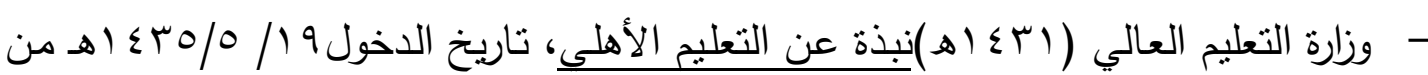

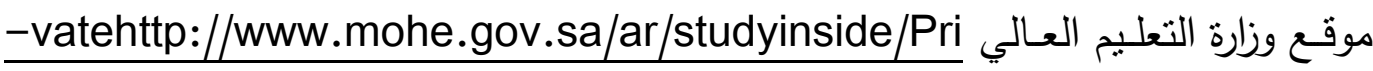
Education/Pages/Overview.aspx-higher

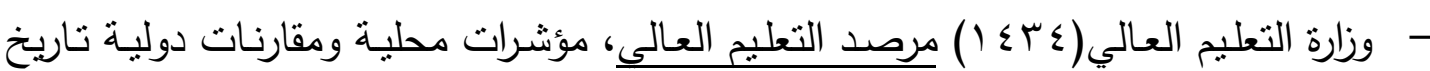

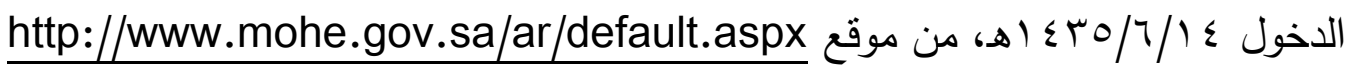

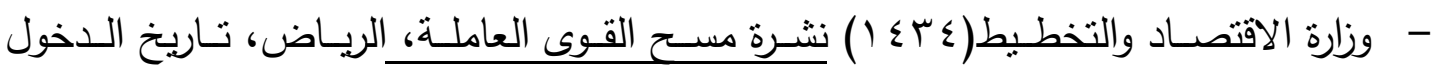

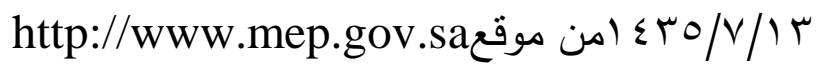


العدد (7 • 1) أبريل ج( ( ) 1 ا •

مجلة كلية التربية بينها

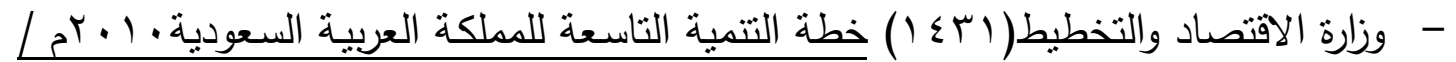

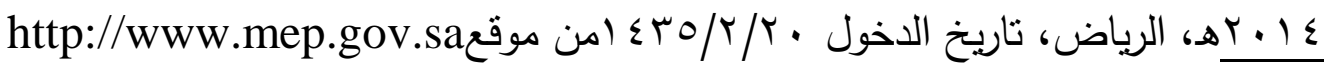

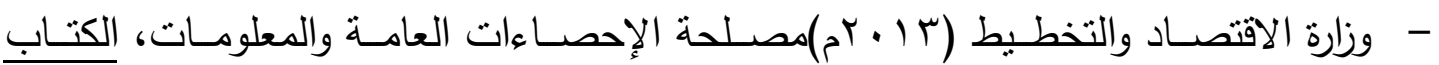

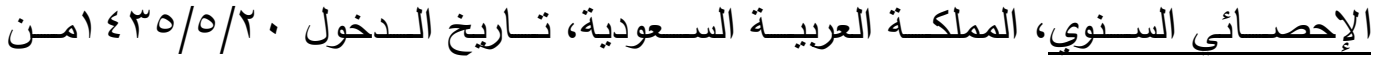
http://www.mep.gov.sa موقع 


\section{Research Conclusion}

This research aims to monitor the fact of the practices applied in the privatization of Saudi Arabia high education institutions, to get to know its pros and cons as well as determining the procedures suggested to be applied.

It aims also to introduce the differences of the responses between the research sample individuals' towards this reality, pros ccons and suggested procedures for privatization in conforming with the variable of university kind

To achieve the goals of the research the researcher used the descriptive

Survey and comparative Curriculum, she also designed a questionnaire Composed of 57 items distributed on 100 academics members at King Abdul Aziz University and CBA faculty in Jeddah.

The research concluded the following results: the fact of the applied practices of privatization was "approved" from all sample individuals. the pros which leads for expansion in privatization ، academics in King Abdul Aziz university response was all "agreed" as for CBA academic was "strongly agreed". As for the cons that imped the expansion in privatization, it got "agreed" from Abdul Aziz university academics and "neutral" from the CBA. In concern of the applicable procedures suggested has been "agreed" from both academics. The results shows the existence of statically signified difference between the average of the individuals response to the pros due to the kind of university in favor of CBA. Also, there is signified difference between the average of sample individuals response about the cons due to the university kind to the favor of king Abdul Aziz university. However there is no signified difference between the average of the sample individuals response to the fact and the procedures suggested to be applied which is considered upon the university kind. Moreover there is a suggested conception of privatization at high education institutions in Saudi Arabia.

Based on the research results the researcher recommends an expansion in the private high education institutions which represent new types. she emphasizes the importance of developing the cooperation between governmental and private high education. she also recommends to apply the suggested conception on high education private institutions at Saudi Arabia 